\title{
FLODIS: A Computer Model to Determine the Flow Distribution and Thermal Response of the Fort St. Vrain Reactor
}

PORTIONS QF THTS REPORT ARE ILLEGTBLE. IT: has been reproduced from the best availablo copy to permit the broadest possible ava1ly ab111ty.

D. D. Paul

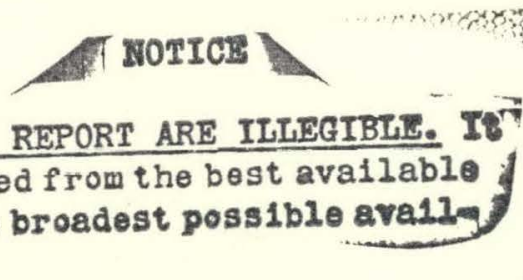




\section{DISCLAIMER}

This report was prepared as an account of work sponsored by an agency of the United States Government. Neither the United States Government nor any agency Thereof, nor any of their employees, makes any warranty, express or implied, or assumes any legal liability or responsibility for the accuracy, completeness, or usefulness of any information, apparatus, product, or process disclosed, or represents that its use would not infringe privately owned rights. Reference herein to any specific commercial product, process, or service by trade name, trademark, manufacturer, or otherwise does not necessarily constitute or imply its endorsement, recommendation, or favoring by the United States Government or any agency thereof. The views and opinions of authors expressed herein do not necessarily state or reflect those of the United States Government or any agency thereof. 


\section{DISCLAIMER}

Portions of this document may be illegible in electronic image products. Images are produced from the best available original document. 
Printed in the United States of America. Available from National Technical Information Service

U.S. Department of Commerce

5285 Port Royal Road, Springfield, Virginia 22161

Price: Printed Copy \$6.75; Microfiche $\$ 2.25$

This report was prepared as an account of work sponsored by the United States Government. Neither the United States nor the Energy Research and Development Administration/United States Nuclear Regulatory Commission, nor any of their employees, nor any of their contractors, subcontractors, or their employees, makes any warranty, express or implied, or assumes any legal liability or responsibility for the accuracy, completeness or usefulness of any information, apparatus, product or process disclosed, or represents that its use would not infringe privately owned rights. 
Contract No. W-7405-eng-26

FLODIS: A COMPUTER MODEL TO DETERMINE THE FLOW DISTRIBUTION AND THERMAL RESPONSE OF THE FORT ST. VRAIN REACTOR

D. D. $\mathrm{Pau} 1$

\section{JUNE: 1976}

(This work was performed for the U.S. Nuclear Regulatory Commission under Interagency Agreement ERDA No. 40-545-75.)

NOTICE: This document contains information of a preliminary nature and was prepared primarily for internal use at the Oak Ridge National Laboratory. It is subject to revision or correction and therefore does not represent a final report.

\section{OAK RIDGE NATIONAL LABORATORY \\ Oak Ridge, Tennessee 37830 \\ operated by \\ UNION CARBIDE CORPORATION \\ for the}

ENERGY RESEARCH AND DEVELOPMENT ADMINISTRATION 
THIS PAGE

\section{WAS INTENTIONALLY LEFT BLANK}


CONTENTS

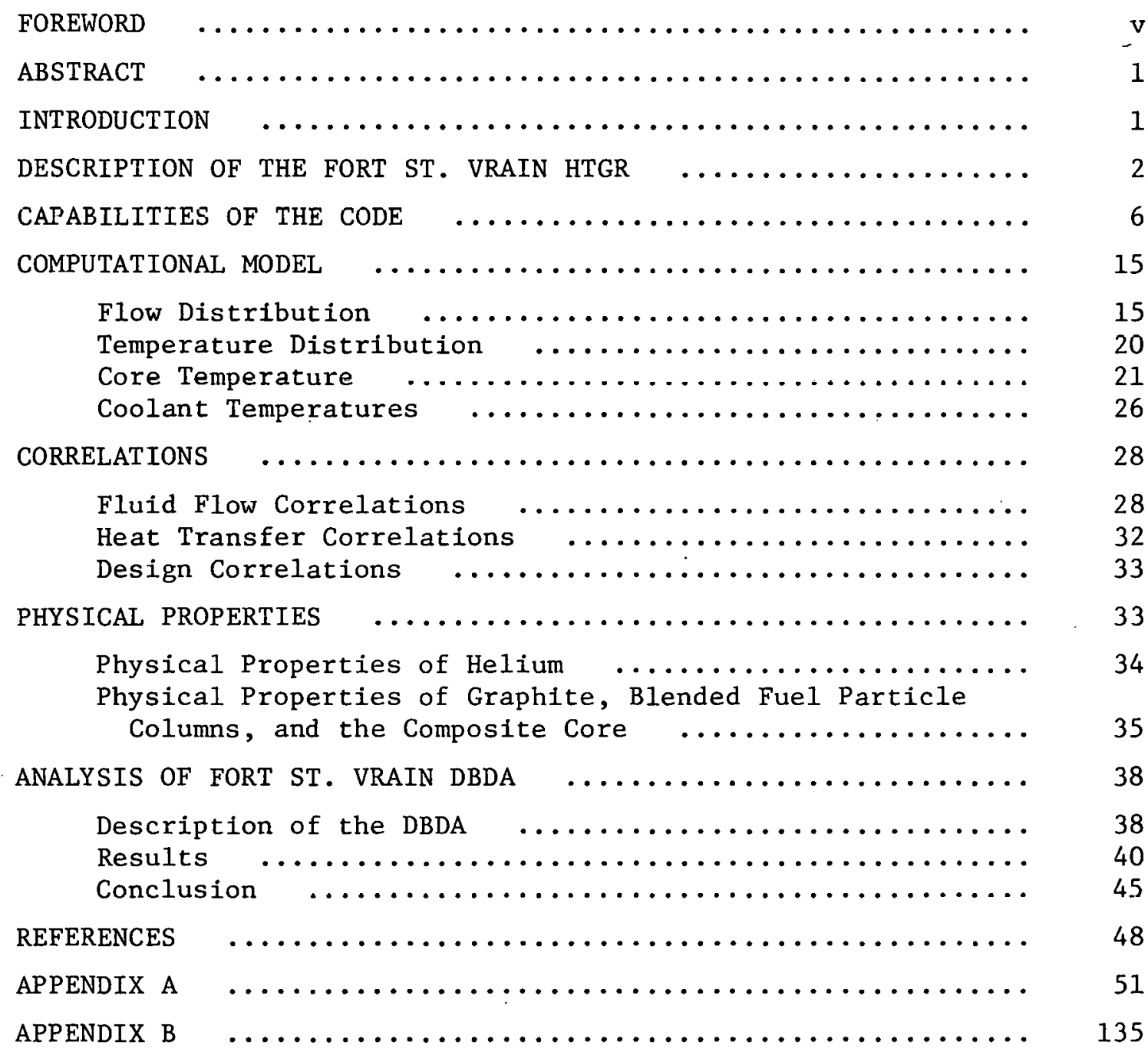


THIS PAGE

\section{WAS INTENTIONALLY LEFT BLANK}


FOREWORD

In February 1975, the Nuclear Regulatory Commission (NRC) asked Oak Ridge National Laboratory (ORNL) to perform an independent analysis of the thermal response of the Fort St. Vrain (FSV) reactor core and primary coolant system following a design-basis depressurization accident (DBDA) with operation on two circulators. The analysis was performed using the CCCM code $^{l}$ at ORNL with the flow distribution assumed to be either proportional to the radial peaking factors or uniform throughout the reactor. This initial study, the results of which were reported in a letter to R. A. Clark, ${ }^{2}$ indicated the importance of being able to accurately determine the time dependent flow distribution in the reactor. For this reason, the development of the FLODIS code was initiated on March 21 , 1975.

Licensing requirements necessitated the quick development of a core model to obtain flow rates to be used as input to the CCCM code. To expedite the initial development process, a simple core model was chosen; it was a model containing only one node per refueling region. This model was completed in May 1975, and the results are presented in a section of the preliminary report on the Fort St. Vrain DBDA. ${ }^{3}$

There was little or no development work done on the FLODIS code between May and August of 1975. However, on August 11-12, 1975, in meetings with the NRC staff in Washington, D.C., it became apparent that more detailed modeling would be necessary to insure the accuracy of the results. At that time, work was undertaken to extend the original one node per refueling region model to include a variable number of up to 100 nodes per refueling region. It should be kept in mind that the equations developed for the single node model are essentially the same as for a multinode model; the main effort was directed toward redimensioning of arrays and setting up DO loops within already existing subroutines. This work was completed in December 1975. 
FLODIS: A COMPUTER MODEL TO DETERMINE THE FLOW

DISTRIBUTION AND THERMAL RESPONSE OF

THE FORT ST. VRAIN REACTOR

D. D. Paul

ABSTRACT

FLODIS is a combined heat transfer and fluid flow analysis calculation written specifically for the core of the Fort St. Vrain reactor. It is a lumped-node representation of the 37 refueling regions in the active core. Heat conduction to the coolant and in the axial direction is represented; however, the effect of conduction between refueling regions is not included. The calculation uses the specified operating conditions for the reactor at power to determine appropriate loss coefficients for the variable orifices in each refueling region. Flow distributions following reactor trip and a reduction in coolant pressure and flow are determined assuming that the orifice coefficients remain constant. Iterative techniques are used to determine the distribution of coolant flow as a function of time during the transient. Results are presented for the evaluation of the transient for the Fort St. Vrain reactor following depressurization and cooling with two circulators operating at $8000 \mathrm{rpm}$.

Key words: Helium, refueling region, conduction, convection, reflector, active core, core support block, orifice, plenum.

INTKÜDŨTCTIUN

The high-temperature gas-cooled reactor (HTGR) is currently being developed by General Atomic Company (GAC), San Diego, California. AIthough there have been only two commercial HTGRs built in the United States (Peach Bottom and Fort St. Vrain), the concept of a gas-cooled reactor is not new. In the past the American effort has been directed toward development of water-cooled reactors; however, the European effort (most notably the British) has been directed toward development of gas-cooled reactors. In fact, the British have over 20 years operatiing experience with gas-cooled reactors. To datc, Fort St. Vrain is 
the largest commercial HTGR built in the United States. It contains many design features proposed for larger gas-cooled reactors.

DESCRIPTION OF THE FORT ST. VRAIN HTGR

The Fort St. Vrain HTGR is a 330-MW(e) demonstration plant located about $60 \mathrm{Km}$ north of Denver, Colorado. Figure 1 shows the arrangement of the primary system within the prestressed concrete reactor vessel (PCRV). ${ }^{4}$ The reactor is located in the upper half of the PCRV and is supported by posts attached to the core support floor. This results in a large plenum area where gas from the entire core can mix before entering the steam generator inlet ducts. Below the core support floor are 12 steam generator modules and 4 helium circulators.

As shown in Fig. 2, the Fort St. Vrain reactor core consists of 37 refueling regions. 5 Each refueling region contains an orifice valve in the upper plenum and a central control column with two control rod channels and a reserve shutdown hole. In a regular refueling region, the central column is surrounded by 6 fuel columns; in a boundary refueling region the control column is surrounded by only 4 fuel columns. Note the boundary refueling regions in Fig. 2 are numbered 20, 23, 26, 29, 32, and 35. All others are regular refueling regions. Also shown in Fig. 2 are the radial peaking factors for each refueling region. The region peaking factors change throughout the fuel cycle. This particular power distribution was chosen as the basis for analysis because it has been judged to be the worst possible case should an accident occur.

About $3.5 \%$ of the total coolant flow passes through the spaces between the side reflector blocks. The other $96.5 \%$ of the total coolant flow is distributed among the 37 refueling regions. Coolant enters a refueling region from the upper plenum through an adjustable orifice valve ${ }^{6}$ shown in Fig. 3. The orifice regulates the amount of flow allowed in each refueling region by adjusting the flow area "seen" by the coolant in the upper plenum. Two concentric cylinders with rectangular slots comprise the orifice device. The orifice is closed by moving the outer cylinder up while the inner cylinder remains stationary.

After being distributed among the holes within a refueling region, the coolant flows downward through the core. Near the bottom of the core 
ORNL-DWG 76-4816

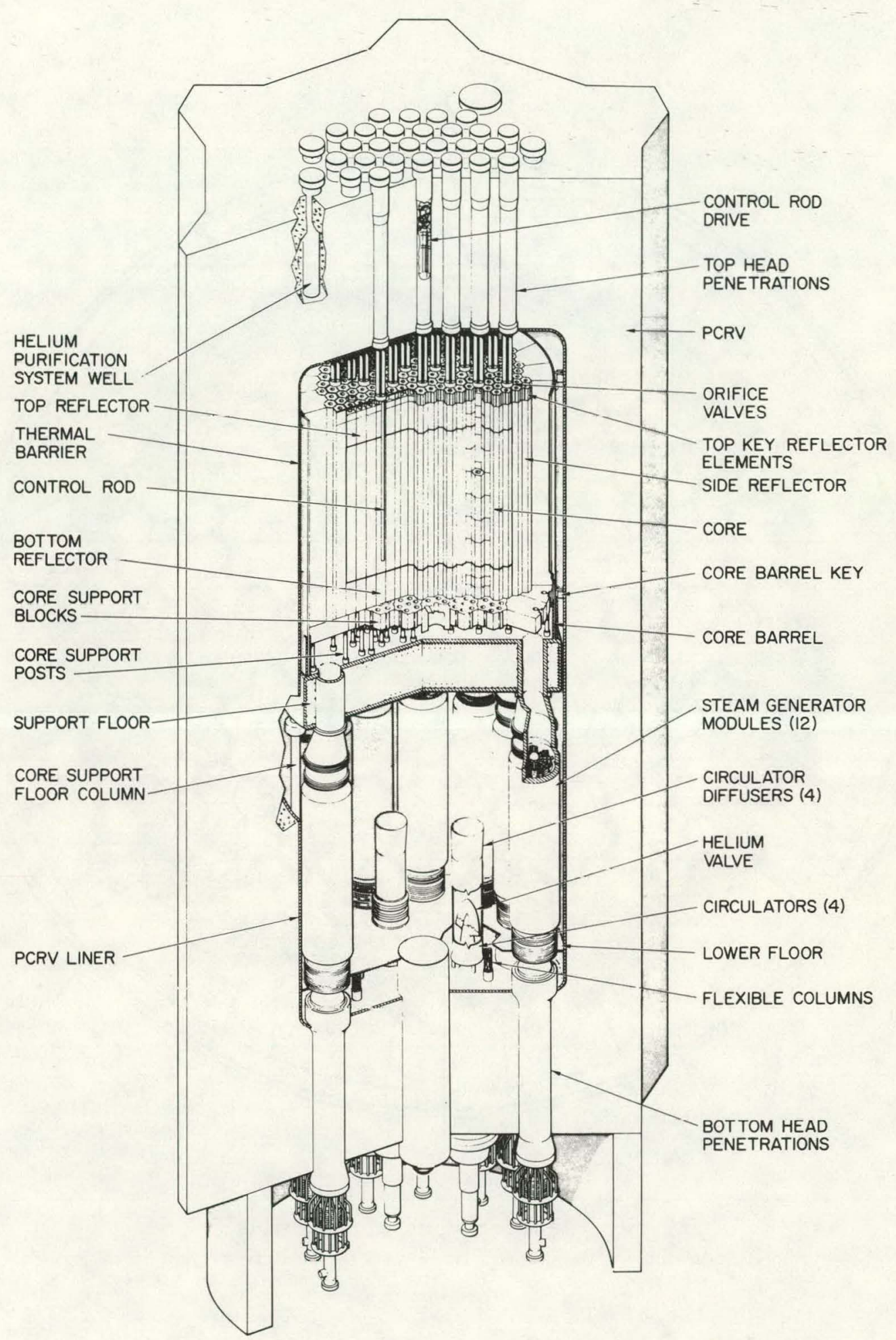

Fig. 1. Reactor arrangement. ${ }^{4}$ 


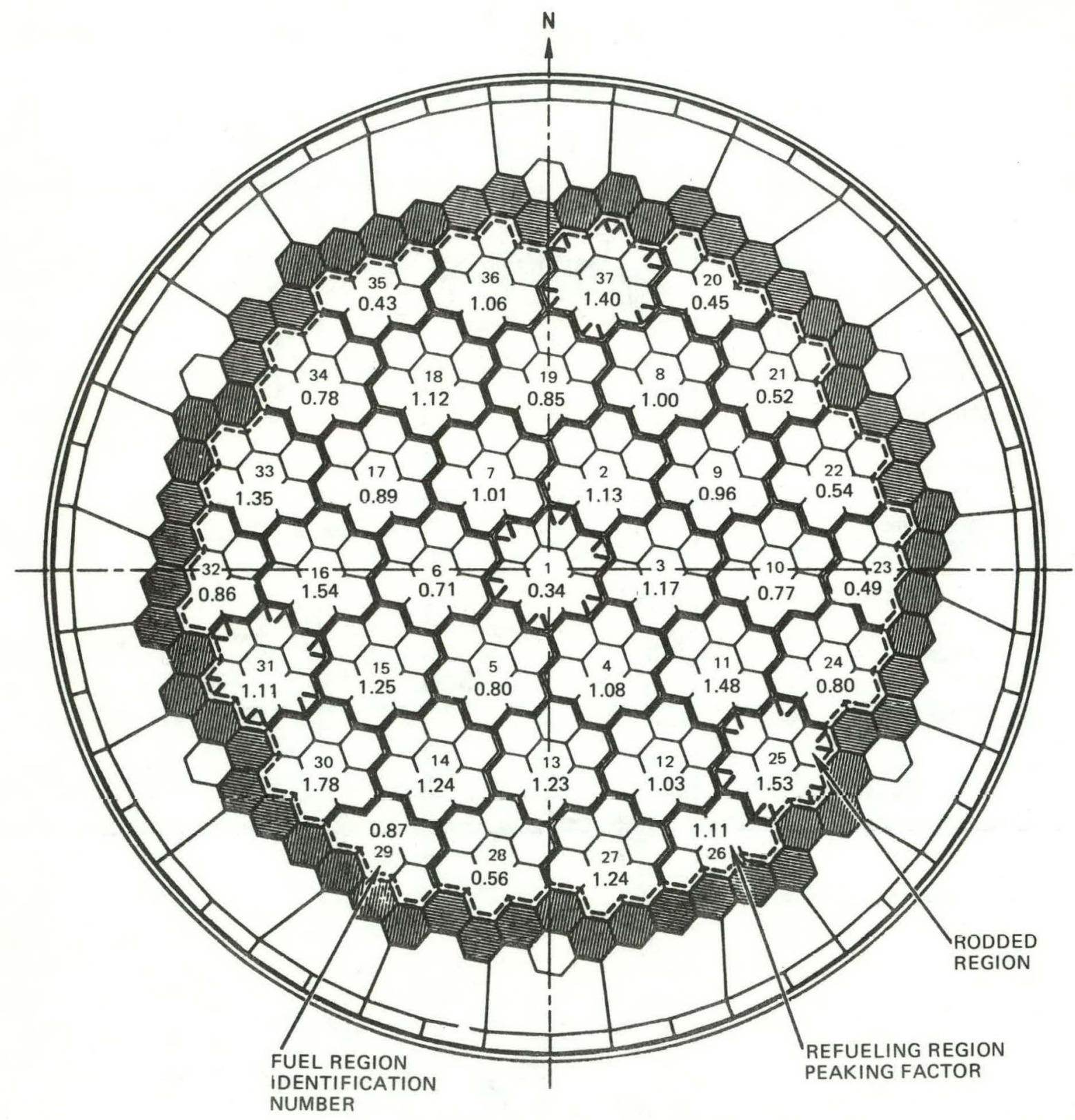

Fig. 2. Reactor core arrangement. ${ }^{5}$ 


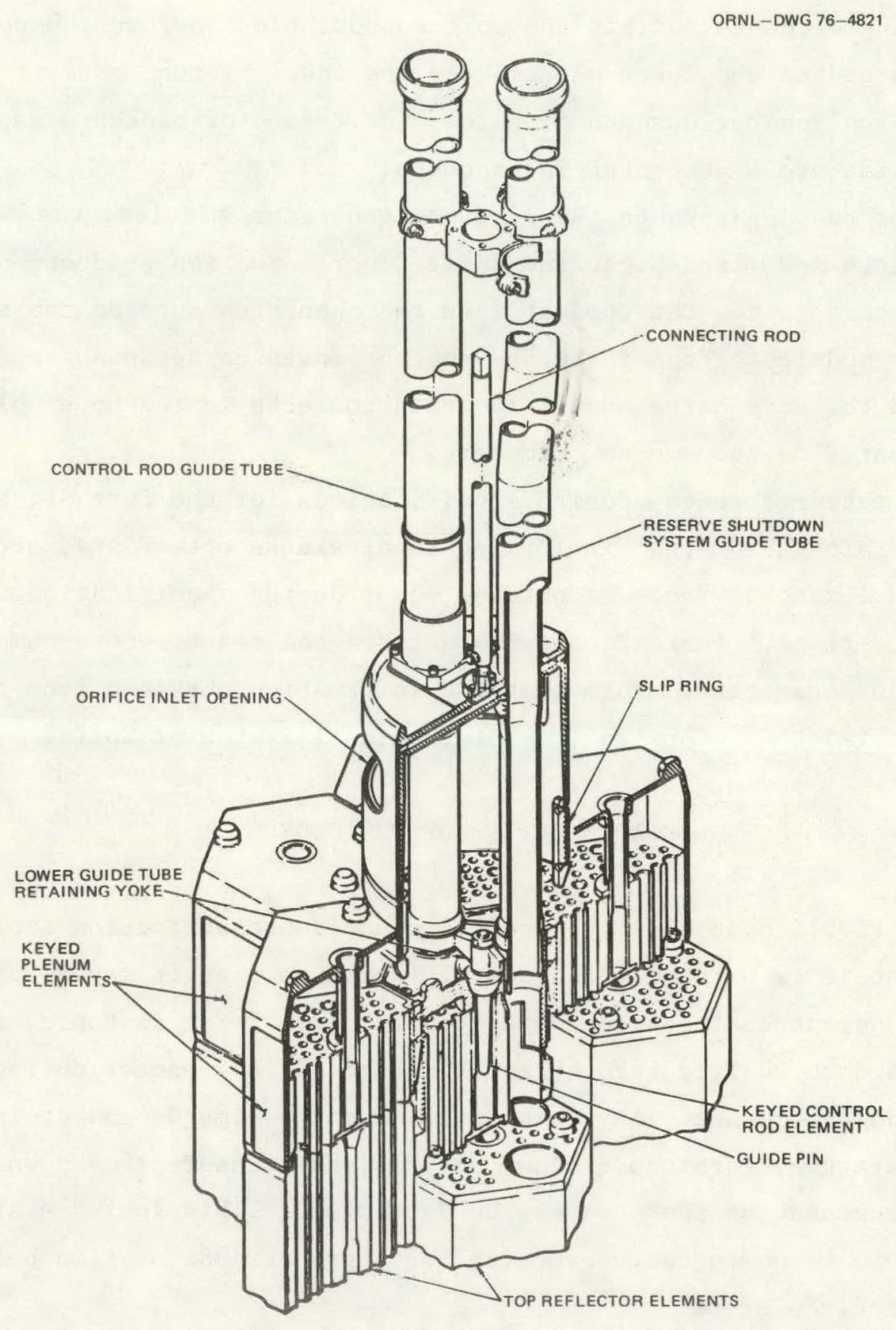

Fig. 3. Top plenum and orifice valve arrangement. ${ }^{6}$ 
the coolant empties into 6 large coolant channels. Figure 4 shows the details of the flow path. ${ }^{7}$ These 6 large coolant channels then collect into a single channel within the core support block before the coolant is discharged to the lower plenum. In the lower plenum, coolant from al1 37 refueling regions and from the side reflector blocks mixes before entering the steam generator inlet ducts.

After passing through the 12 steam generator modules, the coolant collects and mixes below the lower floor. Suction produced by the 4 circulators forces the coolant into the open area outside the steam generator modules. From there the coolant moves up between the PCRV liner and the core barrel until it again collects in the upper plenum. The coolant flow loop is now complete.

For easy reference, design specifications for the Fort St. Vrain reactor, obtained from the Final Safety Analysis Report (FSAR), are included in Tables 1 and 2 . Table 1 contains major design specifications and operating conditions..$^{8}$ Table 2 contains data on the reactor core components and design parameters..$^{9}$ Note that the information obtained from the FSAR was converted to conform to the International System of Units.

\section{CAPABILITIES OF THE CODE}

The FLODIS code was developed to study depressurization accidents in HTGRs, but it is written in a general format so that it may be used for other transient analyses following reactor trip. For instance, the code may be used to analyze the thermal response of the reactor during the normal shutdown sequence. Any transient where the time dependent inlet coolant temperature, total core flow, and coolant pressure are known, the thermal response of the core may be determined. This includes situations where there is no forced convection for short periods of time before startup of the circulators.

Given the proper input data, the FLODIS code calculates the individua1 refueling region flows, pressure drops, and temperature distributions. Input data is kept to a minimum without unduly restricting the capabilities of the user. Output is printed in a manner that is easily read and interpreted by anyone familiar with the reactor. Throughout the entire development of the code, emphasis has been placed on making its use as simple and 


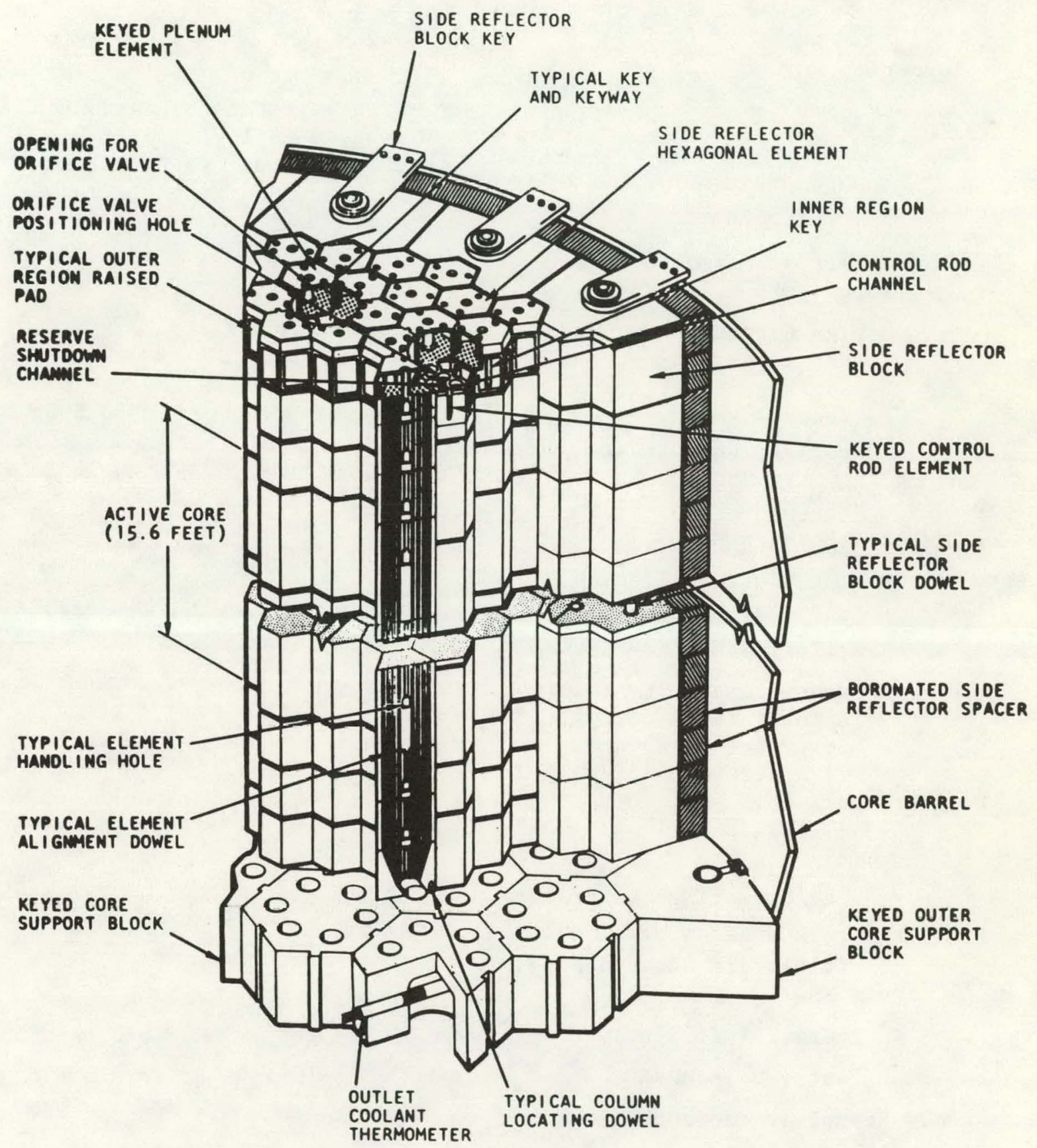

Fig. 4. Core arrangement, elevation section. ${ }^{7}$ 
Table 1. Data on major design characteristics and operating conditions ${ }^{8}$

\section{General}

a. Reactor type

b. Number of primary coolant loops

c. Design output

Net electrical output

(to main power trans-

former), $\mathrm{kW}$

Reactor thermal power, $\mathrm{kW}$

2. Reactor Physics

a. Prompt neutron lifetime for initial core, sec

b. Reactivity characteristics

Excess reactivity $(\Delta \mathrm{k})$

in the initial core at mid-cycle, ${ }^{135} \mathrm{Xe}$ and

$23{ }^{3} \mathrm{~Pa}$ decayed, ${ }^{149} \mathrm{Sm}$

buildup.
at $300 \mathrm{~K}$
at $422 \mathrm{~K}$
at operating temperature

c. Average Neutron Flux

(initial core after one year), $\mathrm{n} / \mathrm{m}^{2} \cdot \mathrm{s}$

Thermal ( $<2.38 \mathrm{ev})$

Fast $(>0.18 \mathrm{Mev})$

d. Reactivity defect in the initial core

Temperature and power

(300 $\mathrm{K}$ to operating),

$\% \Delta \mathrm{k}$

7.2

7.2

$\mathrm{Xe}$ and $\mathrm{Sm}$ (at operating

temperature), \% $\Delta \mathrm{k}$
842 MW(th)

879 MW (th)

High temperature gas-cooled reactor employing a ${ }^{235} \mathrm{U}-$ thorium fuel cycle, helium cooling, and graphite moderation.

2

2

330,000

$>330,000$

842,000

879,000
$2.4 \times 10^{-4}$
$2.4 \times 10^{-4}$
$6.2 \times 10^{17}$
$6.5 \times 10^{17}$
$3.3 \times 10^{17}$
$3.5 \times 10^{17}$

0.136 
Table 1. (continued)

\section{Reactor}

a. Number of fuel elements in core

b. Number of control rods

c. Number of control rod drives

d. Effective core diameter, m

e. Fuel element stack height (cold, new), m

f. Nominal average side reflector thickness (including borated portion for shielding), $m$

g. Top reflector thickness (including borated portion for shielding), $\mathrm{m}$

h. Bottom reflector thickness (including borated portion for shielding), $m$

i. Reactor vessel inside diameter (inside liner), $\mathrm{m}$

j. Reactor vessel inside height (inside liner), $\mathrm{m}$
$842 \mathrm{MW}(\mathrm{th})$

1482

74 (37 pair)

37

5.974

4.755

4.755

1.194

1.194

0.991

0.991

1.189

1.189

9.449

9.449

22.86

22.86

4. Fue1 E.lements
a. Type
b. Cold core array pitch, m
c. Block length (cold), m
d. Active fuel elements per column

Hexagonal graphite blocks containing blended beds of fuel particles

\section{Core Design Operating Conditions}
a. Average power density, $\mathrm{kW} / \mathrm{m}^{3}$
6300
6600
b. Maximum power density, $\mathrm{kW} / \mathrm{m}^{3}$
20000
21000
c. Heat transfer surface area, $\mathrm{m}^{2}$
5816
5816
d. Average heat flux, $\mathrm{kW} / \mathrm{m}^{2}$
142.0
148.3
e. Maximum heat flux, $\mathrm{kW} / \mathrm{m}^{2}$
441.7
460.6
f. Average fuel temperature, $K$
1088
1108
g. Maximum fuel temperature, $\mathrm{K}$
1533
1561
h. Average surface temperature, $K$
978 
Table 1. (continued)

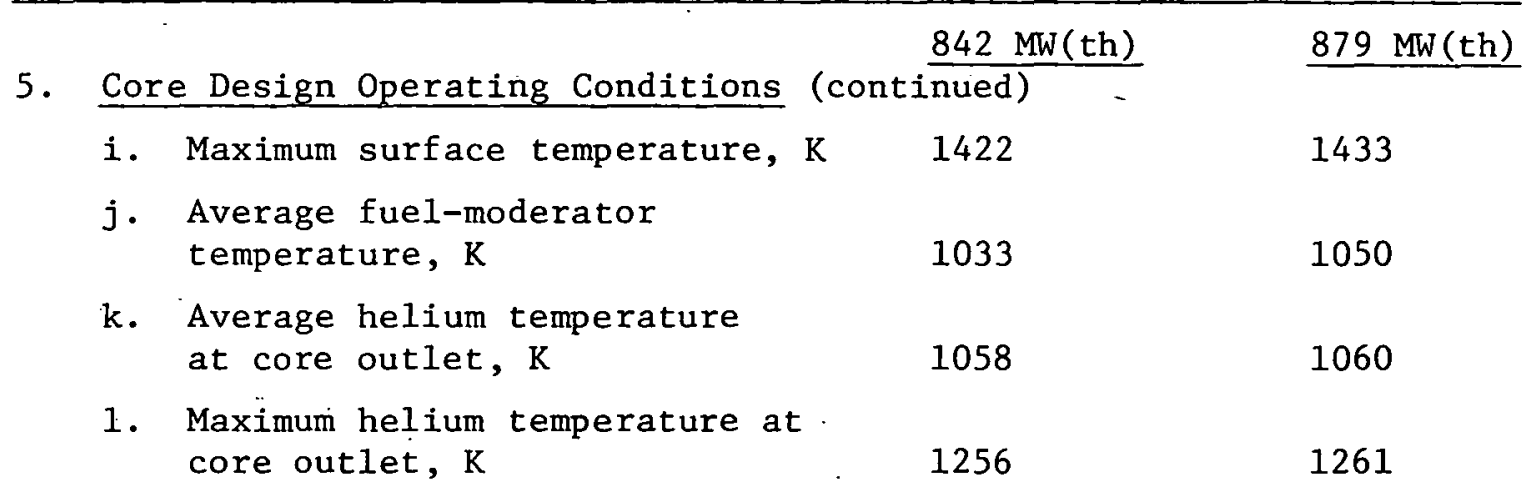

6. Fuel Cycle
a. Refueling period, yr
1
1
b. Fuel 1ifetime, $85 \%$ capacity factor (fuel design basis unly), yr
c. Annual ${ }^{2 \times 35} \mathrm{U}$ feed, equilibrium (in $93 \%$ enriched uranium), $\mathrm{kg} / \mathrm{yr} 220$
d. Annual thorium feed, equilibrium, $\mathrm{kg} / \mathrm{yr}$
e. Conversion ratio
0.60
f. Average burnup per tonne of $U$ and Th, Mwd/tonne
100,000
g. Fissions per initial fissile atom
1.3

7. Primary Coolant System
a. Total helium flow rate in steam generators, $\mathrm{kg} / \mathrm{s}$
429.7
451.1
b. Helium pressure at rated load
(circulator discharge), MPa
4.826
4.875
c. Ratio of gross circulator power to gross thermal output
0.020
0.022
d. System pressure drop (nominal), MPa
0.09653
0.1062
e. Helium temperature at core inlet, $\mathrm{K}$
679
685 f. Helium temperature at steam
generator inlet, $K$
1048
1052
g. Coolant flow direction through core
Downward
Downward 
Table 1. (continued)

7. Primary Coolant System (continued)

$842 \mathrm{MW}(\mathrm{th})$

$879 \mathrm{MW}(\mathrm{th})$

h. Number of primary coolant loops 2

2

i. Helium circulator type

Single-state axial compressor

j. Number of helium circulators

4 (2/1oop)

4 (2/loop)

k. Steam generator type

Once-through ( 1 per loop)

1. Number of identical modules per steam generator

6

6

8. Turbine Plant

a. Main turbine

b. Throttle steam pressure, MPa (gauge)

Tandem-compound double-flow

c. Throttle steam temperature, $\dot{K}$

16.55

16.55

811

811

d. Hot reheat steam pressure (rated load at reheater outlet), MPa

4.137

4.344

e. Reheat steam temperature (at turbine inlet), $\mathrm{K}$

811

811

f. Throttle steam flow rate, $\mathrm{kg} / \mathrm{s}$

291.1

304.9

g. Nominal design back pressure, MPa (at $288 \mathrm{~K}$ temperature)

0.00844

0.00844

h. Feedwater temperature, $K$

479

482

9. Overall Plant Output
a. Gross generator output, MW
342
$>342$

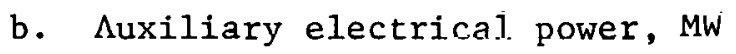
12
12
c. Net station output (to main power transformer), MW
330
$>330$
d. Net station heat rate, $\mathrm{kJ} / \mathrm{kW}$
9179
9168
e. Net station efficiency, \%
39.2
39.3 
Table 2. Core parameters and components ${ }^{9}$

Fuel Element Assembly (room temperature dimensions)

Number required

Power density, $\mathrm{kW} / \mathrm{m}^{3}$

Shape

Material

Width across flats, m

Length, $m$

Diameter of fuel holes, $\mathrm{mm}$

Diameter of coolant holes, mm

Interconnecting dowels

Number of fuel holes

Number of coolant holes

Number of poison holes

Fue1 Beds

Bed diameter, mm

Bed stack length, nominal, m

Bed composition

Number of fuel compositions

$$
\begin{aligned}
& \text { Initial core } \\
& \text { Equilibrium core }
\end{aligned}
$$

\section{Reflector Element Assemblies}

Number required

Shape

Materia1, except topmost layer

Material, topmost layer

Width across flats (rrom temp.), m

Flow area, top and bottom reflector

Interconnecting dowels
1482

6300 (for 842 MW(th) operation)

Hexagonal right prism

Graphite

0.3599

0.7930

12.70

15.875 (6 are 12.70)

3

\begin{tabular}{lll}
$\begin{array}{l}\text { Standard } \\
\text { fuel } \\
\text { element }\end{array}$ & & $\begin{array}{l}\text { Control } \\
\text { element }\end{array}$ \\
\hline 210 & & 120 \\
108 & & 57 \\
6 & 4
\end{tabular}

i2. 75

0.7404

Blended beds of fissile and fertile in particles in specified fuel compositions

13

7

2200

Hexagonal right prism

Graphite and boronated graphite

Boronated graphite and steel

0.3599

Same as fuel elements

3 
Table 2. (continued)

Permanent Reflector Block and Spacer Assemblies

Number required, blocks 312

Number required, spacers 1152

Shape

Irregular

Material, except topmost layer

Graphite and boronated graphite

Material, topmost layer

Boronated graphite and steel

Approximate size, m

$\begin{array}{ll}\text { Blocks } & 0.6 \times 0.8 \times 1.0 \\ \text { Spacers } & 0.25 \times 0.30 \times 0.50 \\ \text { erconnecting dowels, blocks } & 3 \\ \text { erconnecting dowels, blocks } & 2\end{array}$

Core Arrangement

Pitch of fuel columns (room temp.), m 0.3610

Number of fuel columns 247

Number of hexagonal side reflector columns

66

Number of irregular shaped side reflector columns

24

Number of spacer columns 48

Number of control rod channels 74 (2 per fuel region)

Number of reserve shutdown channels 37 (1 per fuel region)

Number of fuel regions 37

Fuel region pitch (room temp.), m 0.9550

Effective core diameter (including reflector), $\mathrm{m} \quad 8.330$

Core height (including reflector), m 7.138

Overall side reflcctor thickness, m 1.194

Overall top and bottom reflector

thickness, m

1.189

Thermal and Hydraulic Parameters at Reactor Design Conditions

$\begin{array}{lll}\text { Gross reactor thermal power MW }(t) & \underline{842} & \underline{879} \\ \begin{array}{l}\text { Total core/reflector coolant flow } \\ \text { rate, } \mathrm{kg} / \mathrm{s}\end{array} & 127.1 & 448.6 \\ \text { Coolant inlet to core, K } & 679 & 685\end{array}$


Table 2. (continued)

\begin{tabular}{|c|c|c|}
\hline Mixed-mean inlet to steam generators, $\mathrm{K}$ & 1048 & 1052 \\
\hline $\begin{array}{l}\text { Coolant channel frontal area fraction, } \% \\
\text { (core average) }\end{array}$ & 17.2 & 17.2 \\
\hline $\begin{array}{l}\text { Total core coolant channel frontal area, } \mathrm{m}^{2} \\
\text { (including column clearance) }\end{array}$ & 5.323 & 5.323 \\
\hline Volume median fuel temperature, $\mathrm{K}$ & 1089 & 1100 \\
\hline Volume median moderator temperature, $\mathrm{K}$ & 1006 & 1011 \\
\hline $\begin{array}{l}\text { Average coolant channel surface heat } \\
\text { flux, } \mathrm{kW} / \mathrm{m}^{2}\end{array}$ & 25,000 & 26,300 \\
\hline $\begin{array}{l}\text { Average coolant surface heat transfer } \\
\text { coefficient, } \mathrm{W} / \mathrm{m}^{2} \cdot \mathrm{K}\end{array}$ & 1306 & 1363 \\
\hline Coolant core inlet pressure, $\mathrm{MPa}$ & 4.819 & 4.868 \\
\hline Total core pressure drop, max., $\mathrm{MPa}$ & 0.0579 & 0.0724 \\
\hline
\end{tabular}


straightforward as possible. This philosophy allows the user to concentrate on using the code as a tool to make evaluations and eliminates time wasted in searching through pages of awkward output data.

Although the code was specifically written for studying the Fort St. Vrain reactor, extension to other HTGR systems would require only redimensioning of arrays and modifying output subroutines. A convenient feature of the FLODIS code is that the number of nodes in the axial direction may be varied from 10 to 100 , depending on the desired accuracy and computer time restrictions. An important 1imitation of the code is that it does not allow conduction of heat between refueling regions.

COMPUTATIONAL MODEL

A mathematical model of the active core and reflector was developed for the Fort St. Vrain reactor. Although the equations describing the system are a series of coupled differential equations, the iteration scheme shown in Fig. 5 allows one to treat the flow distribution independently from the temperature distribution calculations. Care should be exercised in interpreting the above statement. The flow and temperature calculations are coupled through the use of an appropriate iteration scheme. However, for clarity the mathematical model will be presented in two parts - the flow distribution and the temperature distribution.

\section{Flow Diotribution}

The problem may be simply stated as follows: There exists an apparatus consisting of an upper plenum connected to a lower plenum by a number of independent flow regions. Given the total flow entering the upper plenum, determine how the flow will distribute among the various regions. If all the regions were identical, the solution would be obvious, i.e., each region would have the same flow. However, each region may have a different orifice setting, a different number of coolant holes, or a different temperature distribution. Each of these parameters play an important part in determining how the flow is distributed. 


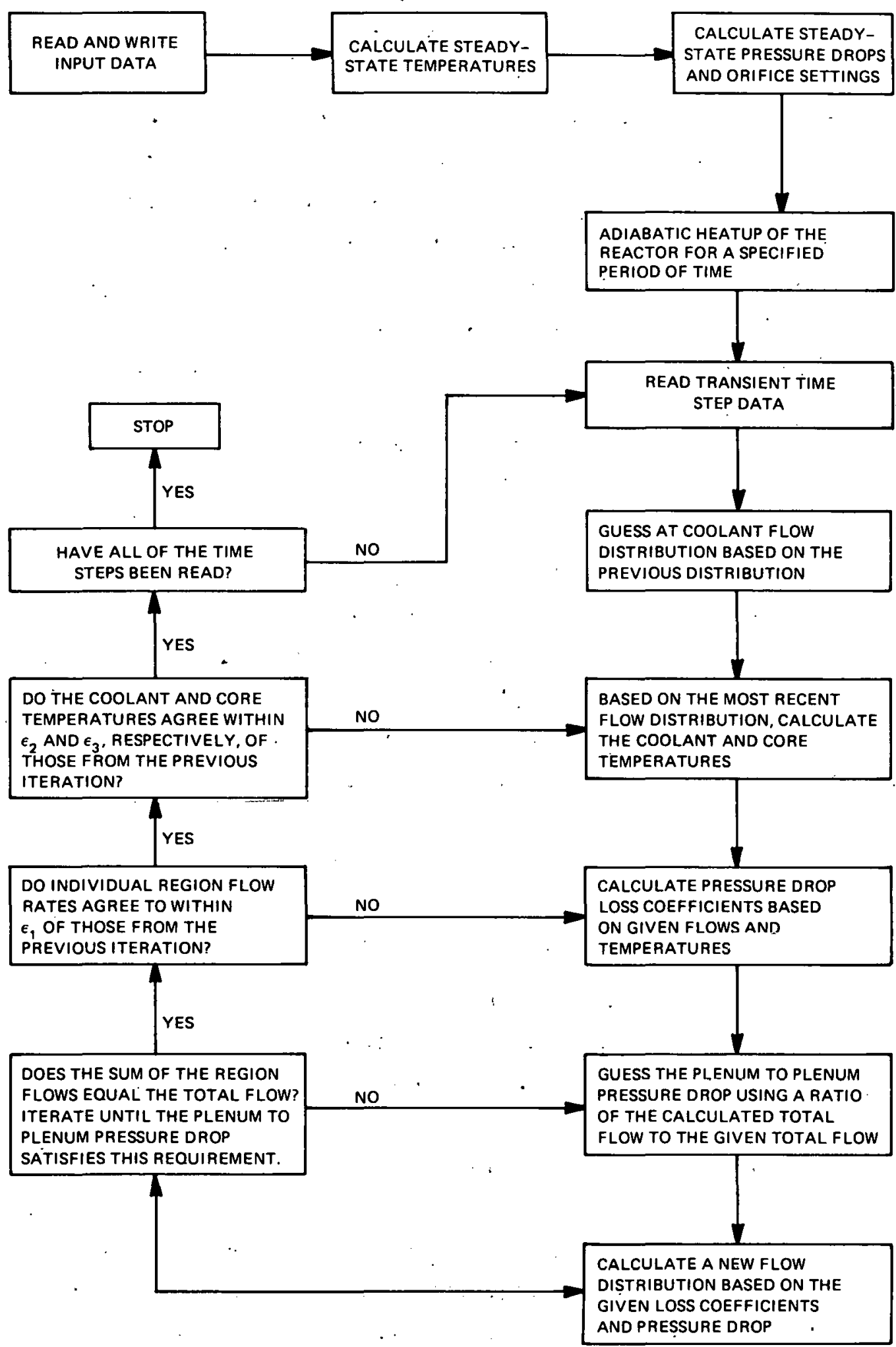

Fig. 5. Iteration procedure. 
The philosophy used to solve the problem is very simple. Regardless of the physical differences between regions, the plenum-to-plenum pressure drop must be the same for all regions. Thus, the flow will distribute in such a manner as to yield the same plenum-to-plenum pressure drop across each region. Since a pressure drop must be calculated, the logical starting point in the analysis is to write a momentum balance. Historically, Leonard Euler (1707-1783) in 1755, was the first to derive the fluid momentum equations. An important limitation of the Euler equations, as they are known today, is the underlying assumption that the fluid is non-viscous. This was remedied in 1822 , when Louis Navier (1785-1836) extended the equations to include the effects of viscous dissipation. Later, George Gabriel Stokes (1819-1903) in a paper in 1845, re-derived the equations in a form that is mathematically more elegant than Navier's original derivation. In fact, it is the momentum equation, as written by Stokes, that is identified today as the Navier-Stokes Equation;

$$
\frac{\partial \rho \vec{v}}{\partial t}=-[\vec{\nabla} \cdot \rho \overrightarrow{v v}]-\vec{\nabla} p-[\vec{\nabla} \cdot t]+\rho \vec{g}
$$

where

$$
\begin{aligned}
& \rho=\text { the local fluld density, } \\
& \vec{v}=\text { the fluid velocity vector, } \\
& p=\text { the local normal pressure, } \\
& t=\text { the fluid stress tensor, } \\
& \vec{g}=\text { the gravitational force vector, } \\
& \vec{\nabla}=\text { the vector differential operator. }
\end{aligned}
$$

Note that the terms $\rho \dot{v}$ and $t$ are not simple vector quantities, but rather are tensor quantities.

To apply the Navier-Stokes equations to the flow problem under consideration, it is desirahle to derive a conservative relation of Eq. (1). The conservative form is obtained by taking the dot product of the local velocity vector with Eq. (1), and integrating over a fixed volume element. The derivation is too lengthy to present here (for an excellent discussion of this derivation see work by Bi.rd 10,11 ), but the result is the widely 
known Bernoulli equation,

$$
\Delta \frac{1}{2} \frac{\left\langle v^{3}\right\rangle}{\langle v\rangle}+\rho g \Delta h+\Delta p+\Omega=0
$$

where

$$
\begin{aligned}
\Delta= & \text { the differencing operator, } \\
\mathrm{h}= & \text { the elevation, } \\
\langle\rangle= & \text { weighted average, } \\
\Omega= & \text { the total irreversible rate of conversion of mechanical to } \\
& \text { internal energy. Often this term is referred to as the } \\
& \text { frictional loss, and generally is estimated by an empirical } \\
& \text { relationship based on experimental data (see section on fluid } \\
& \text { flow correlations). }
\end{aligned}
$$

All other quantities are the same as previously defined.

The above equation is equally valid for either laminar or turbulent flows. It is important to recognize the changes in Eq. (2) resulting from the study of different flow regimes.

The first term in Eq. (2) has a strong dependence on the flow regime. It is often written as:

$$
\frac{\left\langle v^{3}\right\rangle}{\langle v\rangle}=\lambda\langle v\rangle^{2}
$$

where $\lambda=$ the kinetic energy correction factor.

If the fluid velocity distribution is known, the quantity $\lambda$ can be calculated from Eq. (3). For turbulent flow in tubes, the velocity distribution can be approximated by Nikuradse's 1/7-th-power 1aw. ${ }^{12}$ Using this turbulent flow correlation, the value of $\lambda$ is calculated to be 1.058 . For laminar flow in tubes, the velocity distribution can be approximated

*The symbol $\langle>$ means the quantity contained within is averaged. For circular tubes, the average velocity distribution is:

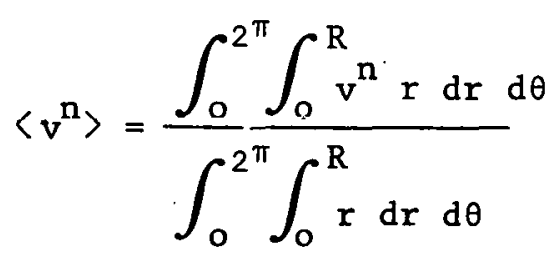


by Poiseuille flow. ${ }^{3}$ Using this relationship, the value of $\lambda$ for laminar flow is 2.00. In general for any velocity distribution, the value of $\lambda$ must necessarily be greater than 1.00. Although the value of $\lambda$ is usually assumed, either knowingly or unknowingly, equal to 1.00 for turbulent flows, this assumption is extremely poor for the case of laminar flows.

The total irreversible rate of conversion of mechanical to internal energy also depends on the flow regime. In general, the quantity $\Omega$ can be written as,

$$
\Omega=\frac{1}{2} \rho\langle v\rangle^{2} \sum_{\substack{\text { loss } \\ \text { factors }}} e_{v}
$$

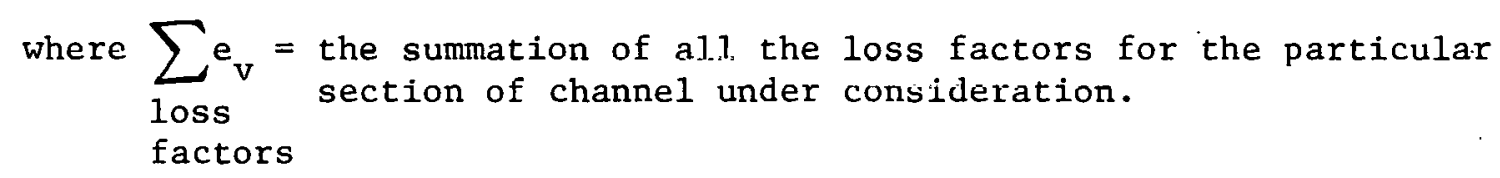

Loss factors may include losses due to duct friction, an expansion, a contraction, or an orifice valve. Furthermore, the loss factors are also dependent on whether the flow is laminar or turbulent. For details on the loss factors, the reader is referred to the section on fluid flow correlations.

Equation (2) may be used for systems in which the viscosity, $\mu$, or the density, $\rho$, varies significantly in the direction of flow by applying it on an incremental basis.along the channel, and then summing the increments to obtain the total pressure drop. By using the equation of continuity,

$$
G=\rho\langle v\rangle
$$

where $G=$ the mass flux in the coolant channels, and the ideal gas law it is possible to derive from Eq. (2) a relationship between the mass flux and the plenum-to-plenum pressure drop as: 


$$
G=\sqrt{\frac{\left(P_{u}-P_{L}\right)+\sum_{\begin{array}{c}
\text { channel } \\
\text { length }
\end{array}} \rho g \Delta h}{\frac{1}{2} \sum_{\substack{\text { channel } \\
\text { length }}}\left(\frac{1}{\rho}\left[\frac{\lambda \Delta T}{\mathrm{~T}}+\sum_{\begin{array}{c}
\text { loss } \\
\text { factors }
\end{array}} \mathrm{e}_{\mathrm{v}}\right]\right)}}
$$

where

$$
\begin{aligned}
& P_{u}=\text { the pressure in the upper plenum, } \\
& P_{L}=\text { the pressure in the lower plenum, }
\end{aligned}
$$

and all other quantities are the same as previously defined.

Equation (6) may now be used in conjunction with an iteration scheme to determine how the flow will distribute among the various regions. The logic of the iteration scheme is:

1. Guess at the total plenum-to-plenum pressure drop.

2. Use Eq. (6) to calculate the flow in each region, based on the assumed pressure drop.

3. Sum the individual flows and compare the calculated total flow with the given total flow.

4. If the calculated total flow is within some small convergence criteria of the given total flow, the problem is solved. If the calcu lated total flow is not within the convergence criterla, the assumed plenum-to-plenum pressure drop is modified by the ratio of the total calculated flow to the total given flow. Steps 2 through 4 are then repeated until convergence is achieved.

Figure 5 shows complete details of the overall iteration procedure.

It is interesting to note that Eq. (6) is valid for upflow or downflow as long as proper care is used to determine the correct signs on the $\Delta$ quantities.

\section{Temperature Distributions}

A detailed temperature distribution must be calculated in order to determine the correct flow distribution. Models are needed to determine the temperatures in both the reactor core and coolant. The development 
of a model will be presented in two parts; a core model consisting of the graphite moderator and fuel sticks, and a coolant model consisting only of fluid flow through the channels.

\section{Core Temperature}

Details of the derivation of the core model will be included because much of the derivation applies to other models currently being used, and this should help in comparing and evaluating these other models.

It is relatively easy to obtain a point-wise or differential energy balance on the entire system. The difficulty lies in trying to solve the resulting differential equation. In any case, the starting point for this analysis will be a statement of the general equation of energy for solids;

$$
\rho(T) C_{p}(T) \frac{\partial}{\partial t} T(\vec{r}, t)=-\vec{\nabla} \cdot \vec{q}(\vec{r}, t)+J(\vec{r}, t)
$$

where

$$
\begin{aligned}
\mathrm{T}(\vec{r}, t)= & \text { the temperature at position } \vec{r}, \text { and at time, } t, \\
\vec{q}(\vec{r}, t)= & \text { the heat flux at position } \vec{r}, \text { time } t, \\
J(\vec{r}, t)= & \text { the volumetric thermal source strength at position } \vec{r}, \\
& \text { time } t, \\
\rho(T)= & \text { the solid density as a function only of the dependent } \\
& \text { variable temperature, } \\
C_{p}(T)= & \text { the heat capacity as a function only of the dependent } \\
& \text { variable temperature. }
\end{aligned}
$$

Care has been taken to write Eq. (7) in completely general form so that assumptions made during the subsequent derivation can be explicitly noted. Equation (7) is valid throughout the entire solid portion of the reactor, whether it be in the fuel sticks, or graphite moderator, or reflector elements. At this point no assumptions have been made.

Throughout the remainder of this section, the function notation will be eliminated. It will be implicitly assumed that the temperature, $T$, the heat flux, $\vec{q}$, and the volumetric thermal source strength, $J$, are functions of the position vector, $\vec{r}$, and the time, $t$. Furthermore, the density, $\rho$, and the heat capacity, $\mathrm{C}_{\mathrm{p}}$, will be implicitly assumed to be functions of the temperaturc. 
It would not be an overstatement to say that it is impossible to finite difference Eq. (7) over the entire reactor. Most finite difference schemes are written for a homogeneous medium with constant thermal properties and "nice" geometries. By "nice" geometries we mean geometries where the boundaries lie naturally along the contours of an orthogonal coordinate system. Examples of nice geometries include rectangular boxes, right-circular cylinders, or spheres. For most practical problems, one or more of these conditions are not wholly satisfied.

For the case of an HTGR core, which consists of a matrix of hexagonal fuel blocks made of pưre graphite with fuel sticks, coolant holes, poison rods, and/or control rod channels interspaced, none of these conditions are satisfied. But the situation is not really as despairing as it first sounds. Equation (7) is 'simply a statement of energy conservation for an infinitesimal element of volume.' If it is integrated over all directions, the result will be a'statement of energy conservation for a small volume element. This is called a conservative relation. The conservative relation is what we are really interested in if we are going to consider the whole reactor core.

Choose as a volume element an axial slice of a refueling region as shown in Fig. 6.

The entire reactor core can be snnstrurted using the volumc element shown above. Equation (7) is integrated over this typical volume element, $\mathrm{V}$, to give

$$
\int_{V} \rho C_{p} \frac{\partial T}{\partial t} d V=\int_{V}-(\vec{\nabla} \cdot \vec{q}) \cdot d V+\int_{V} J d V
$$

For term (a), the integral is evaluated by first making the assumption that the core can be homogenized so that the density, $\rho$, and heat capacity, $C_{p}$, are constant over the volume element and are functions only of the volume average temperature. Then using Leibnitz's rule, term (a) becomes 


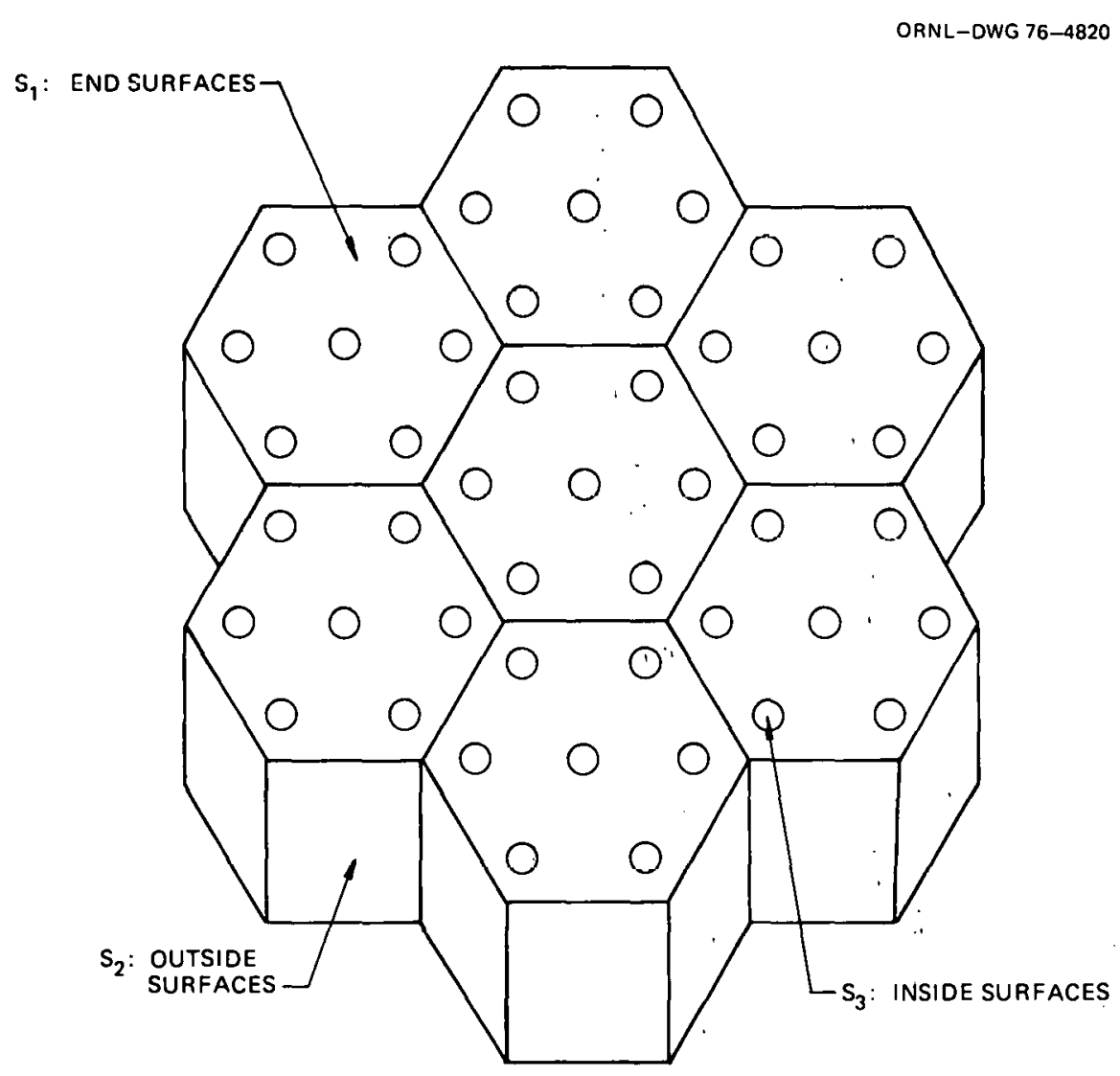

Fig. 6. Axial slice of a refueling region. 


$$
\int_{V} \rho C_{p} \frac{\partial T}{\partial t} d V=\rho C_{p} V \frac{\partial}{\partial t} \frac{1}{V} \int_{V} T d V=m C_{p} \frac{\partial\langle T\rangle}{\partial t}
$$

where

$\mathrm{m}=\rho \mathrm{V}=$ the total mass of the volume element under consideration, $\langle\mathrm{T}\rangle=$ the volume average temperature.

Term (b) is perhaps the most interesting of the terms. By applying the divergence theorem, and dividing the closed surface bounding the volume element into three open surfaces, term (b) becomes

$$
\int_{V}-(\vec{\nabla} \cdot \vec{q}) d V=\int_{S_{1}}-q_{n_{1}} d S+\int_{S_{2}}-q_{n_{2}} d S+\int_{S_{3}}-q_{n_{3}} d S
$$

$$
\left(b_{1}\right)
$$

$\left(b_{3}\right)$

where

$S_{1}=$ the surface bounding the ends of volume element (see Fig. 6),

$S_{2}=$ the surface bounding the outside of the volume element (see Fig. 6),

$S_{3}=$ the surface bounding the inside of the coolant holes in the volume element (see Fig. 6),

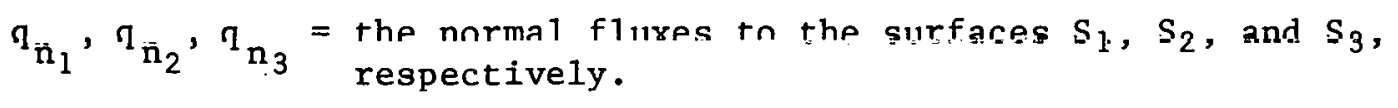

Term $\left(b_{1}\right)$ represents the net rate of energy input by axial conduction of heat. By using Fourier's law of heat conduction, and Gauss's theorem, term $\left(b_{1}\right)$ may be written

$$
\int_{S_{1}}-q_{n_{1}} d S=\int_{S_{1}} k \frac{\partial T}{\partial n} d S=\int_{V} k \frac{\partial^{2} T}{\partial n^{2}} d V=k_{a} V \frac{\partial^{2}\langle T\rangle}{\partial n^{2}}
$$

where $\mathrm{K}_{\mathrm{a}}$ = the effective axial thermal conductivity of the volume element. Term $\left(b_{2}\right)$ represents the net rate of heat input by conduction from adjacent refueling regions. Since the surface, $s_{2}$, does not conform to the contours of an orthogonal coordinate system, the heat $f l u x, q_{n_{2}}$, cannot be replaced by a simple expression of Fourier's law of heat conduction 
as was done for term $\left(b_{1}\right)$. For the time being, the problem is more or less ignored by assuming the heat flux, $q_{n_{2}}$, through this surface is negligibly small in comparison with the other terms in the equation. This is equivalent to saying that $S_{2}$ is an adiabatic surface.* Thus, term $\left(b_{2}\right)$ is

$$
\int_{S_{2}}-q_{n_{2}} d S=\int_{S_{2}} 0 d s=0
$$

It is interesting to note that had a volume element been chosen that conformed to an orthogonal coordinate system, Fourier's law could have been applied and the combined result of terms $\left(b_{1}\right)$ and $\left(b_{2}\right)$ would give

$$
\int_{S_{1}}-q_{n_{1}} d s+\int_{S_{2}}-q_{n_{2}} d S=k V \nabla^{2}\langle T\rangle,
$$

which is Laplace's equation for heat conduction.

Term $\left(b_{3}\right)$ is the integral over the coolant channel surfaces. By assuming Newton's law of cooling is valid, term $\left(b_{3}\right)$ becomes

$$
\int_{S_{3}}-q_{n_{3}} d S=\int_{S_{3}} H(\theta-\langle T\rangle) d S=\operatorname{HA} \zeta\left(\theta_{\text {in }}-\langle T\rangle\right)
$$

where

$$
\begin{aligned}
& \mathrm{H}=\text { the local heat transfer coefficients, } \\
& \mathrm{A}=\text { the total heat transfer area within the volume element, } \\
& \theta=\text { the coolant temperature, } \\
& \zeta=\text { an averaging factor, defined in the section on coolant } \\
& \text { temperatures, which accounts for the variation of coolant } \\
& \text { temperature over the length of the volume element. }
\end{aligned}
$$

If Eqs. (11), (12), and (14) are combined, the final expression for term (b) is

$$
\int_{V}-(\vec{\nabla} \cdot \vec{q}) d V=k V \frac{\partial^{2}\langle T\rangle}{\partial n^{2}}+0+\operatorname{HA\zeta }\left(\theta_{\text {in }}-\langle T\rangle\right)
$$

*The RECA code, ${ }^{14}$ written by General Atomic Company; does not make this assumption, and therefore must make some approximation: for..this integral. 
Term (c) is easily evaluated. By definition, the volumetric thermal source strength is the heat generated per unit volume per unit time at a particular location. The integral over the volume is thus

$$
\int_{V} \mathrm{~J} \mathrm{dV}=\mathrm{Q}
$$

where $Q=$ the total heat generated per unit time in the volume element. By substituting Eqs. (9), (15), and (16) into Eq. (7) the following conservative relation is obtained:

$$
m C_{p} \frac{\partial\langle T\rangle}{\partial t}=k V \frac{\partial^{2}\langle T\rangle}{\partial n^{2}}-H A \zeta\left(\langle T\rangle-\theta_{1 n}\right)+Q
$$

Note that the differential equation is now written in terms of volume average temperatures of a nodal element instead of point-wise temperatures. Since Eq. (17) was derived for an arbitrary volume element, it may be finite differenced throughout the reactor core. A differencing method proposed by Crank and Nicholson ${ }^{15}$ is used to reduce Eq. (17) to a set of linear algebraic equations. The algebraic equations are solved using a Gauss-Seidel iteration procedure. 16

\section{Coolant Temperatures}

Heat transfer in a moving fluid is a very complicated physical process that depends strongly on the flow regime. Without the use of experimental data, only the simplest of fluid heat transfer problems could be solved. However, experimental data is available in the form of correlations that relate a heat transfer coefficient to the flow regime and fluid properties. Using these correlations, an energy balance gives

$$
W C_{p} \frac{d \theta}{d z}=H P(\langle T\rangle-\theta)
$$

where

$$
\begin{aligned}
\theta & =\text { the bulk coolant temperature, } \\
\langle\mathrm{T}\rangle & =\text { the corresponding volume average core temperature, } \\
\mathrm{H} & =\text { the local heat transfer coefficient, }
\end{aligned}
$$


$\mathrm{W}=$ the coolant mass flow rate,

$\mathrm{C}_{\mathrm{p}}=$ the coolant heat capacity,

$\mathrm{P}=$ the wetted perimeter of the channel,

$z=$ the axial length along the channel.

Equation (18) implicitly assumes the thermal "inertia" of the fluid is negligibly small in comparison with the other terms. This is a good approximation for most gases. Integrating Eq. (18) over the length of the volume element shown in Fig. 6 gives

$$
\theta(z)=\langle T\rangle-\left(\langle T\rangle-\theta_{\text {in }}\right) e^{-\alpha z}
$$

where

$$
\alpha=\frac{\mathrm{HP}}{\mathrm{WC}_{\mathrm{P}}}
$$

It is assumed the inlet fluid temperature is known. Equation (19) may then be used in conjunction with $\mathrm{Eq}$. (17) to obtain the thermal response of the system. Note that Eq. (19) must be solved over each nodal volume.

It is convenient to use Eq. (19) to determine the total quantity of heat transported from a volume element by convection. By definition, for a differential segment $\mathrm{dz}$, the differential quantity of heat transported by convection is

$$
\mathrm{dQ}_{\mathrm{C}}=\mathrm{HP}[\langle\mathrm{T}\rangle-\theta(z)] \mathrm{d} z
$$

Equation (19) may be substituted into Eq. (21), and the differential quantities summed by integration to give

$$
Q_{c}=\operatorname{HPL}\left[\left(\langle T\rangle-\theta_{i n_{n}}\right) \frac{1-e^{-\alpha L}}{\alpha L}\right]
$$

where $\mathrm{L}=$ the length of the volume element.

The expression in brackets can be interpreted as the average temperature difference between the wall and the coolant over a single nodal volume. For convenience, the averaging factor can be defined as,

$$
\zeta=\frac{1-e^{-\alpha L}}{\alpha L}
$$

and the convective heat transport term becomes 


$$
Q_{c}=\operatorname{HPL} \zeta\left(\langle T\rangle-\theta_{\text {in }}\right)
$$

This expression is now exact in that it correctly accounts for the variation of the temperature difference between the wall and the coolant. Note that Eq. (24) is the same as the expression given in Eq. (17) for the convective heat transport, except now the term $\zeta$ has been defined by Eq. (23).

\section{CORRELAT IONS}

Correlations of existing experimental data are needed before the momentum and energy equations can be solved. The correlations chosen for use in the FLODIS code were picked for either their wide acceptance or particular applicability to HTGRs. These correlations may be divided into three classes - fluid flow correlations, heat transfer correlations, and design correlations.

\section{Fluid Flow Correlations.}

Perhaps the most important parameter, as far as determining the flow distribution, is the loss factor due to friction in the channel. This loss factor is defined by,

$$
e_{f}=\frac{4 L}{D} f
$$

where

$$
\begin{aligned}
e_{f} & =\text { channel friction loss factor to be used in Eq. (6), } \\
L & =\text { length of channel under consideration, } \\
D & =\text { hydraulic diameter of the channel, } \\
f & =\text { Fanning friction factor.* }
\end{aligned}
$$

The Fanning friction factor is a function of the flow regime.

For turbulent flows, $\operatorname{Re} \geq 4291$, Drew, Koo, and McAdams ${ }^{17}$ have found that the friction factor data could be correlated to within $\pm 5 \%$ by

*Note: the Moody friction factor, $f^{\prime}$, is defined by $f^{\prime}=4 f$. Both friction factors are used extensively throughout the literature, and special attention should be given to using them properly. 


$$
\mathrm{f}=0.0014+0.125 \mathrm{Re}^{-0.32}
$$

where $\operatorname{Re}=$ Reynolds number.

Strictly speaking, the above friction factor is valid only for isothermal flow in smooth pipes. For non-isothermal flow, Davenport and Magee 18 have found that local values of the friction factor were correlated when the fluid properties-were evaluated at the film temperature, defined to be the average of the wall and bulk temperature. Thus, Eq. (26) can be used for non-isothermal flow if the viscosity, used to calculate the Reynolds number, is evaluated at the film temperature.

For laminar flows, $\operatorname{Re} \leq 1600$, the friction factor is determined by the classical result of Hagen-Poiseuille 13,19 ,

$$
\mathrm{f}=\frac{16}{\mathrm{Re}}
$$

In the transition zone, $1600<\operatorname{Re}<4291$, a frlction factor is arbitrarily defined to be a straight line on semi-log paper, connecting the points at $\operatorname{Re}=1600$ and $\operatorname{Re}=4291$. This necessarily makes the friction factor a continuous, single-valued function of the Reynolds number. Because the bounding limits of the Reynolds number were nicely chosen, the value of the friction factor in the transition region is constant,

$$
\mathrm{f}=0.01
$$

Correlations for expansion and contraction loss coefficients are also lieeded. Kaye ${ }^{20}$ has derived analytical expressions that have been checked and found to be in good agreement with experimental data. For expansion loss coefficients, Kays suggests

$$
e_{e}=1-2 \beta_{s} \sigma+\sigma^{2}\left(2 \beta_{L}-1\right)
$$

where

$$
\begin{aligned}
& e_{e}=\text { loøe coeffirient due to a sudden expansion, } \\
& \sigma=\text { ratio of small area to large area, } \\
& \beta_{L}=\text { momentum correction factor for large tube, }
\end{aligned}
$$




$$
\beta_{S}=\text { momentum correction factor for small tube.* }
$$

For contraction loss coefficients, Kays suggests

$$
e_{c}=\frac{1-\lambda_{L} \sigma^{2} c^{2}-2 c+2 \beta_{s} c^{2}}{c^{2}}-\left(1-\sigma^{2}\right)
$$

where

$$
\begin{aligned}
e_{c} & =\text { loss coefficient due to a sudden contraction, } \\
\mathrm{C} & =\text { jet contraction area, } \\
\lambda_{\mathrm{L}}= & \text { kinetic energy correction factor in large tube (see Eq. (3) } \\
& \text { for a detailed definition). }
\end{aligned}
$$

Values of the jet contraction area, as a function of the ratio of areas, $\sigma$, is given by Rouse 21 in Table 3 .

Table 3. Jet contraction area ${ }^{21}$

\begin{tabular}{lc}
\hline $\begin{array}{l}\text { Ratio of } \\
\text { areas, } \sigma\end{array}$ & $\begin{array}{c}\text { Jet contraction } \\
\text { area, C }\end{array}$ \\
\hline & \\
0.0 & 0.611 \\
0.1 & 0.612 \\
0.2 & 0.616 \\
0.3 & 0.622 \\
0.4 & 0.631 \\
0.5 & 0.644 \\
0.6 & 0.662 \\
0.7 & 0.687 \\
0.8 & 0.722 \\
0.9 & 0.781 \\
1.0 & 1.000 \\
\hline
\end{tabular}

Equations (29) and (30) are valid for any flow regime provided the momentum and kinetic energy correction factors are known. For laminar flow, the correction factors may be calculated assuming Poiseuflle flow ${ }^{13}$,

*The momentum correction factor may be calculated if the velocity distribution is known. By definition,

$$
\beta=\frac{\left\langle V^{2}\right\rangle}{\langle V\rangle^{2}}
$$

See Eq. (2) for more details concerning the averaging notation, $\langle$. 
they are $\beta_{S}=1.33, \beta_{L} \cong 1.00$, and $\lambda_{L} \cong 1.00$. For turbulent flow, there is little error in assuming the velocity distribution is flat; the correction factors are $\beta_{S} \cong 1.00, \beta_{L} \cong 1.00$, and $\lambda_{L} \cong 1.00$. Using the above information, the expansion and contraction loss coefficients, given by Eqs. (29) and (30), respectively, are functions only of the ratio of areas, $\sigma$.

Finally, a correlation is needed to determine the orifice loss coefficient. A diagranı of the orifice is shown in Fig. 3. Applying the Bernoulli equation across the orifice opening gives the classical result

$$
W=C_{D} A_{0} \sqrt{2 \rho \Delta P_{0}}
$$

where

$$
\begin{aligned}
C_{D} & =\text { coefficient of discharge, } \\
A_{0} & =\text { orifice area, } \\
\Delta P_{0} & =\text { pressure drop across orifice. }
\end{aligned}
$$

Solving for the pressure drop, and multiplying and dividing by the square of the channel flow area, $\mathrm{A}_{\mathrm{c}}{ }^{2}$, gives

$$
\Delta P_{0}=\left[\frac{1}{C_{D}^{2}} \frac{A_{c^{2}}}{A_{o}^{2}}\right] \frac{W^{2}}{2 p A_{C}^{2}}
$$

The quantity in brackets is the orifice loss coefficient to be used in Eq. (6). By definition,

$$
C_{0}=\left[\begin{array}{ll}
\frac{1}{C_{D^{2}}} & \frac{C^{2}}{A_{o^{2}}}
\end{array}\right]
$$

where $C_{0}=$ orifice loss coefficient.

The coefficient of discharge, $C_{D}$, was first measured experimentally by Sir Isaac Newton and found to have a value of 0.61 , which is the accepted value today. Admittedly, the above analysis is a somewhat oversimplification of the orifice model considering the complexity of the design. Experimental verification is needed before the results of this model can be documented. 


\section{Heat Transfer Correlations}

Classically, three heat transfer regimes are identified - turbulent, laminar and transitional. In the turbulent region, Re 210,000 , Seider and Tate 22 have recommended the following correlation,

$$
\mathrm{Nu}=0.023 \operatorname{Re}^{0.8} \operatorname{Pr}^{0.33}\left(\frac{\mu}{\mu_{w}}\right)
$$

where

$$
\begin{aligned}
\mathrm{Nu} & =\text { Nusselt number, } \\
\mathrm{Re} & =\text { Reynolds number, } \\
\operatorname{Pr} & =\text { Prandt } 1 \text { number, } \\
\mu & =\text { fluid viscosity evaluated at the bulk temperature, } \\
\mu_{\mathrm{w}} & =\text { fluid viscosity evaluated at the wall temperature. }
\end{aligned}
$$

All fluid thermal properties are evaluated at the bulk temperature, except $\mu_{w}$ as already noted.

In the laminar region, $\operatorname{Re} \leq 2100$, a Graetz number correlation given by McCabe and $\operatorname{Smith}^{23}$ is used,

$$
\mathrm{Nu}=1.85 \mathrm{Gr}^{0.33}\left(\frac{\mu}{\mu_{\mathrm{w}}}\right)
$$

where $\mathrm{Gr}=\left(\operatorname{Re} \operatorname{Pr} \frac{\mathrm{D}}{\mathrm{L}}\right)=$ Graetz number.

All fluid thermal properties are again evaluated at the bulk temperature, except $\mu_{w}$ as already noted.

In the transition region, a heat transfer coefficient is not easily defined due to instabilities of the fluid motion. Fortunately, the transition region is small, $2100<\operatorname{Re}<10000$, and not likely to be encountered in most calculations. A transion region heat transfer coefficient was defined by a linear interpolation on log-log paper of the heat transfer coefficient versus Reynolds number between the points at $\operatorname{Re}=2100$ and $\operatorname{Re}=10,000$. This necessarily makes the heat transfer coefficient a continuous, single-valued function over the entire flow spectrum. 


\section{Design Correlations}

A design correlation by General Atomic Company 24 was used to simulate the time dependent decay heat following scram of the reactor. This correlation is given by:

$$
f(t)=0.128(t+0.0003796)^{-0.261}
$$

where

$$
\begin{aligned}
f(t)= & \text { fraction of steady-state power remaining after } t \text { seconds } \\
& \text { following shutdown, } \\
t= & \text { time following shutdown, seconds. }
\end{aligned}
$$

It is desirable for calculating the core temperature distribution to define an average heat generation rate over a time step. By definition, the average value during interval from $t_{1}$ to $t_{2}$ is:*

$$
\langle f\rangle=\frac{0.1732}{\left(t_{2}-t_{1}\right)}\left(t_{2}+3.796 E-4\right)^{0.739}-\left(t_{1}+3.796 E-4\right)^{0.739}
$$

Equation (37) is used to calculate the average heat generation rate over an interval of time. The average heat generation rate, Q, will be used in conjunction with Eq. (17).

\section{PHYSICAL PROPERTTES}

In general, the physical properties of most materials are dependent on the temperature. For gases, some properties may further depend on the pressure. Since the thermal response of the reactor is likely to span a wide range of temperatures and pressures, the dependence of . the physical properties on these parameters must be accurately known to model the system.

*The average value over an interval of time.is given by.

$$
\langle\dot{f}\rangle=\frac{\int_{t_{1}}^{t_{2}} f(t) d t}{\int_{t_{l}}^{t_{2}} d t}
$$




\section{Physical Properties of Helium}

The physical properties of pure helium have been studied widely and are very well known. $25,26,27$ At ORNL, Tallackson ${ }^{28}$ has made an extensive study of many of the correlations currently available and good agreement with experimental data has been confirmed. The set of properties used in the FLODIS code were obtained from Sanders, ${ }^{29}$ who has summarized and elaborated on data presented by Wilson, 30 General Dynamics Corporation. Helium properties of interest are viscosity, thermal conductivity, heat capacity at constant pressure, and density.

The viscosity of helium is represented by the empirical relation,

$$
\mu=\left(6.7 \times 10^{-4}\right) \mathrm{T}^{0.68}
$$

where

$$
\begin{aligned}
& \mu=\text { viscosity of helium, } 1 \mathrm{~b}_{\mathrm{m}} / \mathrm{ft} \cdot \mathrm{h}\left(1 \mathrm{lb} \mathrm{b}_{\mathrm{m}} / \mathrm{ft} \cdot \mathrm{h}=4.134 \mathrm{E}-4 \mathrm{~Pa} \cdot \mathrm{s}\right), \\
& \mathrm{T}=\text { absolute temperature, }{ }^{\circ} \mathrm{R}\left(1^{\circ} \mathrm{R}=0.5556 \mathrm{~K}\right)
\end{aligned}
$$

The thermal conductivity of helium may be represented by polynomials of the form,

$$
K=A(P)+B(P) T+C(P) T^{2}
$$

where

$$
\begin{aligned}
\mathrm{K}= & \text { thermal conductivity of helium, Btu/hr} \cdot \mathrm{ft} \cdot{ }^{\circ} \mathrm{F} \\
& \left(1 \mathrm{Btu} / \mathrm{hr} \cdot \mathrm{ft} \cdot{ }^{\circ} \mathrm{F}=1.7307 \mathrm{~W} / \mathrm{m} \cdot \mathrm{k}\right) \\
\mathrm{T}= & \text { absolute temperature, }{ }^{\circ} \mathrm{R}\left(1{ }^{\circ} \mathrm{R}=0.5556 \mathrm{~K}\right) \\
\mathrm{P}= & \text { pressure, psia }(1 \mathrm{psia}=6895 \mathrm{~Pa}) \\
& \text { and the coefficients } \mathrm{A}(\mathrm{P}), \mathrm{B}(\mathrm{P}), \text { and } \mathrm{C}(\mathrm{P}) \text { are obtained from } \\
& \text { Table } 4 .
\end{aligned}
$$

The thermal conductivity at any particular temperature and pressure may be found by calculating the thermal conductivity at the temperature and two bounding pressures given in Table 4; then a linear interpolation between these two values will yield the thermal conductivity at the desired pressure.

The heat capacity of helium remains essentially constant over the operating conditions experienced in HTGRs. A value of $1.2425\left(\mathrm{Btu} / 1 \mathrm{~b}_{\mathrm{m}}{ }^{\circ} \mathrm{F}\right)$ was chosen for the Fort St. Vrain analysis. 
Table 4. Polynomial coefficients for thermal conductivity of helium 29

\begin{tabular}{cccc}
\hline Pressure (psia) & A & B $\times 10^{5}$ & $\mathrm{C} \times 10^{8}$ \\
\hline 14.7 & 0.08092 & 9.994 & -1.100 \\
100.0 & 0.08350 & 10.084 & -1.136 \\
1000.0 & 0.08638 & 10.161 & -1.204 \\
2000.0 & 0.08691 & 10.309 & -1.278 \\
\hline
\end{tabular}

The density of helium may be calculated directly from the ideal gas law. The relationship is

$$
\rho=\frac{\mathrm{PM}}{\mathrm{RT}}
$$

where

$$
\begin{aligned}
& \rho=\text { density of helium, } \\
& P=\text { pressure, } \\
& M=\text { molecular weight of helium, } \\
& R=\text { gas constant } \\
& T=\text { absolute temperature. }
\end{aligned}
$$

Compressibility factors for helium at design conditions in HTGRs are on the order of 1.01. At depressurized conditions, the compressibility factor is 1.00 . Therefore, the ideal gas law may be used with little error at all temperatures and pressures existing in HTGRs.

\section{Physical Properties of Graphite, Blended Fuel Particle Column, and the Composite Core}

The following information was obtained from the Fort St. Vrain Final Safety Analysis Report, ${ }^{31}$ unless otherwise noted. The physical properties of interest are density, thermal conductivity, and heat capacity.

For pure graphite, the bulk density is approximately $1714 \mathrm{~kg} / \mathrm{m}^{3}$ (107 $\left.1 \mathrm{~b}_{\mathrm{m}} / \mathrm{ft}^{3}\right)$. Its thermal conductivity varies from $38.1 \mathrm{~W} / \mathrm{m} \cdot \mathrm{K}\left(22 \mathrm{Btu} / \mathrm{h} \cdot \mathrm{ft} \cdot{ }^{\circ} \mathrm{F}\right)$ for unirradiated graphite to $17.3 \mathrm{~W} / \mathrm{m} \cdot \mathrm{K}\left(10 \mathrm{Btu} / \mathrm{h} \cdot \mathrm{ft} \cdot{ }^{\circ} \mathrm{F}\right)$ for graphite irradiated to an accumulated fast neutron fluence greater than $5 \times 10^{21}$ nvt. 
The heat capacity of pure graphite may be calculated as a function of temperature by,

$$
C_{p}=-0.103+6.472 \times 10^{-4} \mathrm{~T}-2.667 \times 10^{-7} \mathrm{~T}^{2}+3.97 \times 10^{-11}-\mathrm{T}^{3}
$$

where

$$
\begin{aligned}
\mathrm{C}_{\mathrm{p}} & =\text { heat capacity, } \mathrm{Btu} / 1 \mathrm{~b}_{\mathrm{m}} \cdot{ }^{\circ} \mathrm{F}\left(1 \mathrm{Btu} / 1 \mathrm{~b}_{\mathrm{m}} \cdot{ }^{\circ} \mathrm{F}=4184 \mathrm{~J} / \mathrm{kg} \cdot \mathrm{K}\right) \\
\mathrm{T} & =\text { absolute temperature, }{ }^{\circ} \mathrm{R}\left(1{ }^{\circ} \mathrm{R}=0.5556 \mathrm{~K}\right)
\end{aligned}
$$

For blended fuel particle columns, the thermal conductivity is given conservatively as $3.5 \mathrm{~W} / \mathrm{m} \cdot \mathrm{K}\left(2.0 \mathrm{Btu} / \mathrm{h} \cdot \mathrm{ft} \cdot{ }^{\circ} \mathrm{F}\right)$ from $1170 \mathrm{~K}\left(1650^{\circ} \mathrm{F}\right)$ to $1590 \mathrm{~K}\left(2400^{\circ} \mathrm{F}\right)$. The volumetric heat capacity is given by

$$
\rho C_{p}=3.38+2.74 \times 10^{-2} \mathrm{~T}-4.88 \times 10^{-6} \mathrm{~T}^{2}-0.146 \times 10^{6} / \mathrm{T}^{2}
$$

where

$$
\begin{aligned}
\rho= & \text { density of fuel column, } 1 \mathrm{~b}_{\mathrm{m}} / \mathrm{ft}^{3}\left(1 \mathrm{~b}_{\mathrm{m}} / \mathrm{ft}^{3}=16.02 \mathrm{~kg} / \mathrm{m}^{3}\right) \\
\mathrm{C}_{\mathrm{p}}= & \text { heat capacity of fuel column, Btu/1 } \mathrm{b}_{\mathrm{m}} \cdot{ }^{\circ} \mathrm{F}\left(1 \mathrm{Btu} / 1 \mathrm{~b}_{\mathrm{m}} \cdot{ }^{\circ} \mathrm{F}=\right. \\
\quad 4184 \mathrm{~J} / \mathrm{kg} \cdot \mathrm{K}) & \\
\mathrm{T}= & \text { absolute temperature, }{ }^{\circ} \mathrm{R}\left(I^{\circ} \mathrm{R}=0.5556 \mathrm{~K}\right)
\end{aligned}
$$

For the composite core, the effective thermal conductivity is different in the axial and radial directions. Turner and Siman-Tov ${ }^{32}$ recommended the following relationship be used for calculating the effective thermal conductivity in the axial direction,

$$
\mathrm{K}_{\mathrm{a}}=\sum_{i=1}^{3} \mathrm{P}_{i} \mathrm{~K}_{\mathrm{i}}
$$

where

$\mathrm{K}_{\mathrm{a}}=$ effective axial thermal conductivity,

$\mathrm{P}_{i}=$ percentage of axial, cross-sectional area associated with the fuel, graphite, and helium, respectively, and

$\mathrm{K}_{i}=$ thermal conductivity of the fuel, graphite, and helium, respectively.

Using conservatively low values of the component thermal conductivities gives an effective axial thermal conductivity of $9.81 \mathrm{~W} / \mathrm{m} \cdot \mathrm{K}(5.67$ $\left.\mathrm{Btu} / \mathrm{hr} \cdot \mathrm{ft} \cdot{ }^{\circ} \mathrm{F}\right)$. 
For the effective thermal conductivity in the radial direction, Turner and Siman-Tov ${ }^{3} 3$ recommend

$$
\mathrm{K}_{\mathrm{r}}=\frac{1}{\mathrm{~W}} \sum_{i=1}^{7} \mathrm{w}_{i} \mathrm{~K}_{i}
$$

where

$$
\begin{aligned}
& \mathrm{K}_{\mathrm{r}} \text { = effective radial thermal conductivity, } \\
& \mathrm{W}_{i}=\text { width of the } i \text { th heat flow path, } \\
& \mathrm{K}_{1}=\text { effective thermal conductivity of the ith heat flow path, } \\
& \mathrm{w}=\sum_{i=1}^{7} \mathrm{w}_{\mathbf{i}} \\
& \mathrm{K}_{1}=\frac{\mathrm{L}}{\quad \therefore \frac{\mathrm{L}}{\mathrm{L}_{\mathrm{i}}}+\frac{\mathrm{L}-\mathrm{L}_{i}}{\mathrm{~K}_{\mathrm{g}}}} ; i=1 \text { to } 3 \\
& \mathrm{~K}_{\mathrm{i}}=\frac{\mathrm{L}}{\frac{\mathrm{L}}{\mathrm{K}_{\mathrm{f}}}+\frac{\mathrm{L}-\mathrm{L}_{i}}{\mathrm{~K}_{\mathrm{g}}}} ; \mathrm{i}=4 \text { to } 6 \\
& \mathrm{~K}_{7}=\mathrm{K}_{\mathrm{g}}
\end{aligned}
$$

- Since the FLODIS code neglects the effect of heat conduction between refueling regions, the above expression is presented for purely academic reasons.

The heat capacity of the composite core is obtained by taking the mass weighted average of the component heat capacities. The temperature dependent component heat capacities are obtained from Eqs. 41 and 42 for the graphite and fuel, respectively. 
ANALYSIS OF FORT ST. VRAIN DBDA

During routine examination prior to startup, cracks were discovered in the curvic coupling and bucket areas of the Pelton turbines. Further investigation $^{34}$ revealed the cause of the cracks was high-cycle fatigue resulting from operation of the circulators at $10,550 \mathrm{rpm}$. Results of the above study indicated the problem could be eliminated by the Pelton turbines at a reduced speed. A reduced high-speed trip setting of $8800 \mathrm{rpm}$ was chosen by Public Service Company of Colorado (PSC).

The reduction in speed of the helium circulators when driven by Pelton turbines will reduce the gas flow available for emergency cooling. This led to a review of postulated reactor events that involve operation of the Pelton turbines. PSC concluded that the rapid depressurization accident resulted in the most severe conditions requiring operation of the Pelton turbines. What follows is an independent analysis of the DBDA with the Pelton turbines operating at the reduced specifications.

\section{Description of the DBDA}

There are many different sequences of design basis depressurization accidents. The accident considered in this report consisted of the following assumptions and events: The reactor is operating at $105 \%$ power. All fission products are at their equilibrium values. At time zero, the reactor instantaneously experiences a depressurization from $4.868 \mathrm{MPa}$ (706 psia) to $0.0876 \mathrm{MPa}(12.7 \mathrm{psia})$, and simultaneously the control rods shutdown the reactor. The reactor heat generation follows a standard decay curve. It is assumed the reactor heats up adiabatically for the first 300 seconds ( $5 \mathrm{~min}$ ) before forced convective cooling by the Pelton turbines is started. Furthermore, when the cooling is started it is assumed only two of the four available circulators are operational; in other words, it is assumed that complete failure of one of the redundant loops has occurred. Thus, only six of the 12 steam generator ducts are providing suction for the circulation of helium. The remaining two circulators are assumed to be operating at a speed of $8000 \mathrm{rpm}$.

At $8000 \mathrm{rpm}$, the actual total flow delivered by the circulators as a function of time is given in Fig. 7. The corresponding helium temperature 


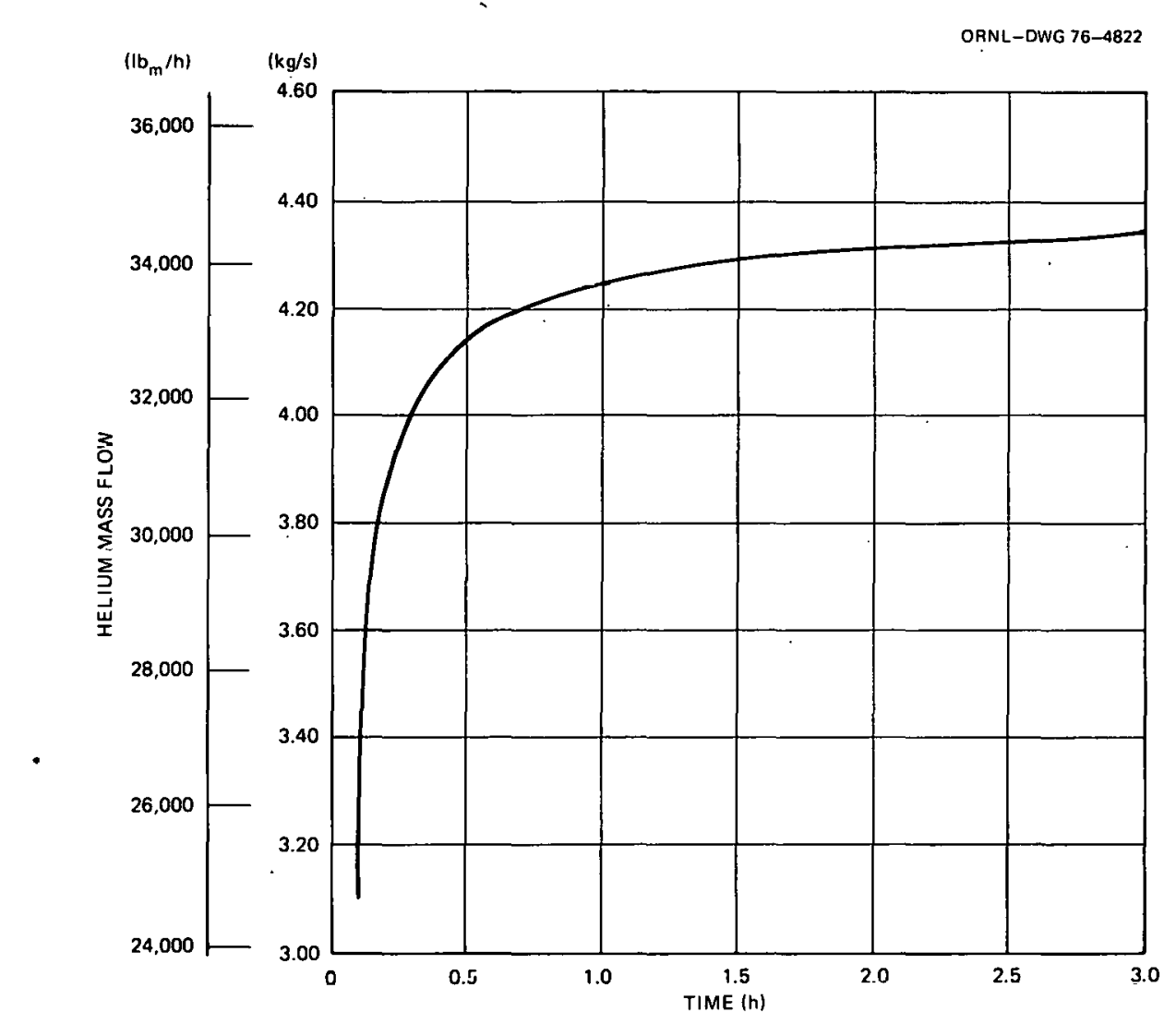

Fig. 7. Total helium flow delivered by two circulators operating at 8000 rpm. 35 
at the core inlet as a function of time is given in Fig. 8. Both of these curves were constructed using data provided by PSC. ${ }^{35}$ All of the input data needed to execute a transient analysis is now known.

\section{Results}

The above information along with other required input (see Appendix A for code input specifications) were used to perform the analysis of the rapid depressurization accident. For interpreting the results, the temperature corresponding to the critical safety limit is compared with the temperature calculated by the FLODIS code for any given component. In general, the critical safety limit is defined as the temperature at which the material or component no longer satisfactorily meets its design requirements. Values of the critical safety limit for a few materials of interest are presented in Table 5. This table also shows the maximum temperature attained by the same material during the course of the transient as calculated by the FLODIS code.

Table 5. Critical safety limits

\begin{tabular}{lcc}
\hline \multicolumn{1}{c}{$\begin{array}{c}\text { Material or } \\
\text { component }\end{array}$} & $\begin{array}{r}\text { Critical safety } \\
\text { limit (K.) }\end{array}$ & $\begin{array}{c}\text { FLODIS maximum } \\
\text { tcmpcrature (IK) }\end{array}$ \\
\hline $\begin{array}{l}\text { Coated fuel particles } \\
\text { Silica thermal barrier on } \\
\text { the surface of the core }\end{array}$ & 1870 & 1550 \\
$\begin{array}{l}\text { support floor } \\
\text { Thermal barrier lining of } \\
\text { the steam generator inlet } \\
\text { ducts }\end{array}$ & 1370 & 1480 \\
\hline
\end{tabular}

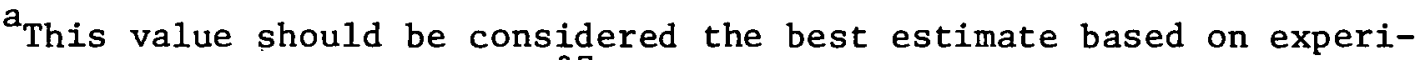
mental mixing data from Walker. ${ }^{37}$ It is not necessarily a conservative value.

For coated fuel particles the critical safety limit is the temperature above which there is a rapid deterioration of the fission product barrier. This limit occurs at a temperature of $1870^{\circ} \mathrm{K}\left(2900^{\circ} \mathrm{F}\right)$. Figure 9 shows the maximum active core temperatures for selected refueling 


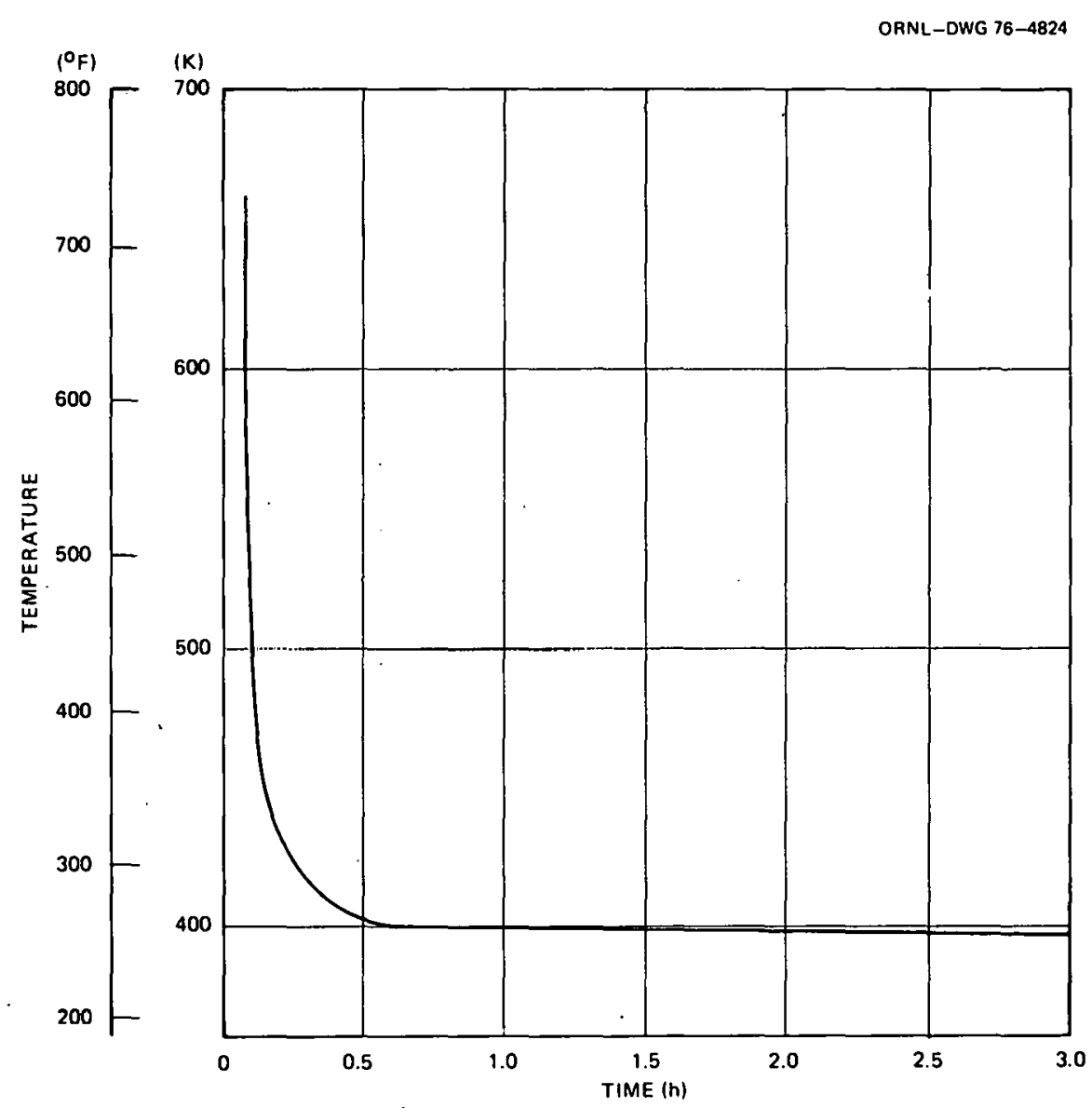

Fig. 8. Temperature of helium in the upper plenum following a DBDA. 35 


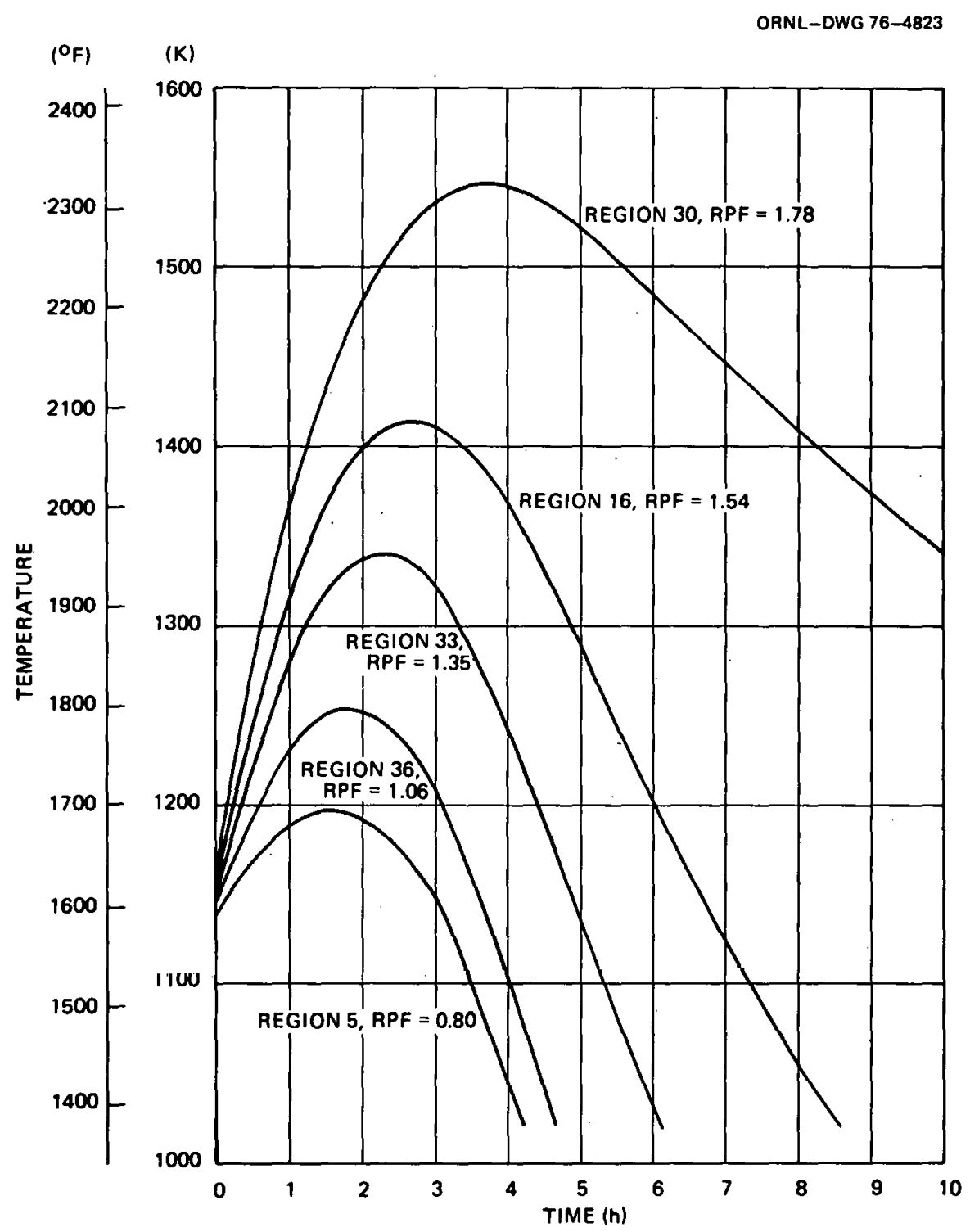

Fig. 9. Refueling region maximum temperatures in the active core following a DBDA. 
regions. The top two curves correspond to the regions with the highest power generation rates. Between the curves with radial peaking factors (RPF) of 1.54 and 1.06 , there are 14 regions with maximum temperature curves bounded by these limits. There are 20 regions that have curves which lie below the bounding curve with $\mathrm{RPF}=1.06$. From this graph it is obvious that none of the 37 refueling regions have temperatures that exceed the critical safety limit for coated fuel particles. Furthermore, the maximum temperatures are low enough so as to ensure that there will not be any abnormal release of fission products from the coated fuel particles as a consequence of this severe accident.

Lining the core support floor are cast silica blocks. These blocks form a thermal barrier between the hot gas leaving the refueling regions and the concrete of the core support floor. It may be assumed that hot gas leaving a refueling region impinges in a jet against the silica thermal barrier. Thus, the gas outlet temperature of a refueling region may conservatively be taken as the local temperature of the silica thermal barrier. The critical safety limit for this component is the temperature which causes creep deformation of $2 \%$ at the expected operating stress level in the structural elements in one hour. Table 5 gives its critical safety 1 imit as $1640^{\circ} \mathrm{K}\left(2500^{\circ} \mathrm{F}\right)$. Figure 10 shows the refueling region outlet gas temperature following a rapid depressurization accident. Again, the top two curves represent the highest powered regions. The regions with radial peaking factors equal to 1.78 and 1.54 , the two hottest regions, have maximum exit gas temperatures which are approximately $160^{\circ} \mathrm{K}$ $\left(300^{\circ} \mathrm{F}\right)$ and $300^{\circ} \mathrm{K}\left(540^{\circ} \mathrm{F}\right)$ below the critical safety limit of $1640^{\circ} \mathrm{K}(2500$ ${ }^{\circ} \mathrm{F}$ ). The other 35 refueling regions have maximum exit gas temperatures which are much cooler than the above mentioned hot channels. It may be concluded that the silica thermal barrier lining the core support floor maintains good structural integrity throughout the accident sequence and should not be significantly altered in any way due to the thermal response of the reactor during the analyzed transient.

At this time, the FLODIS code does not have the capabilities to calculate the temperature of the thermal barrier lining the steam generator inlet ducts. However, based on physical arguments, an understanding of the magnitude of these temperatures can be estimated. In this accident 


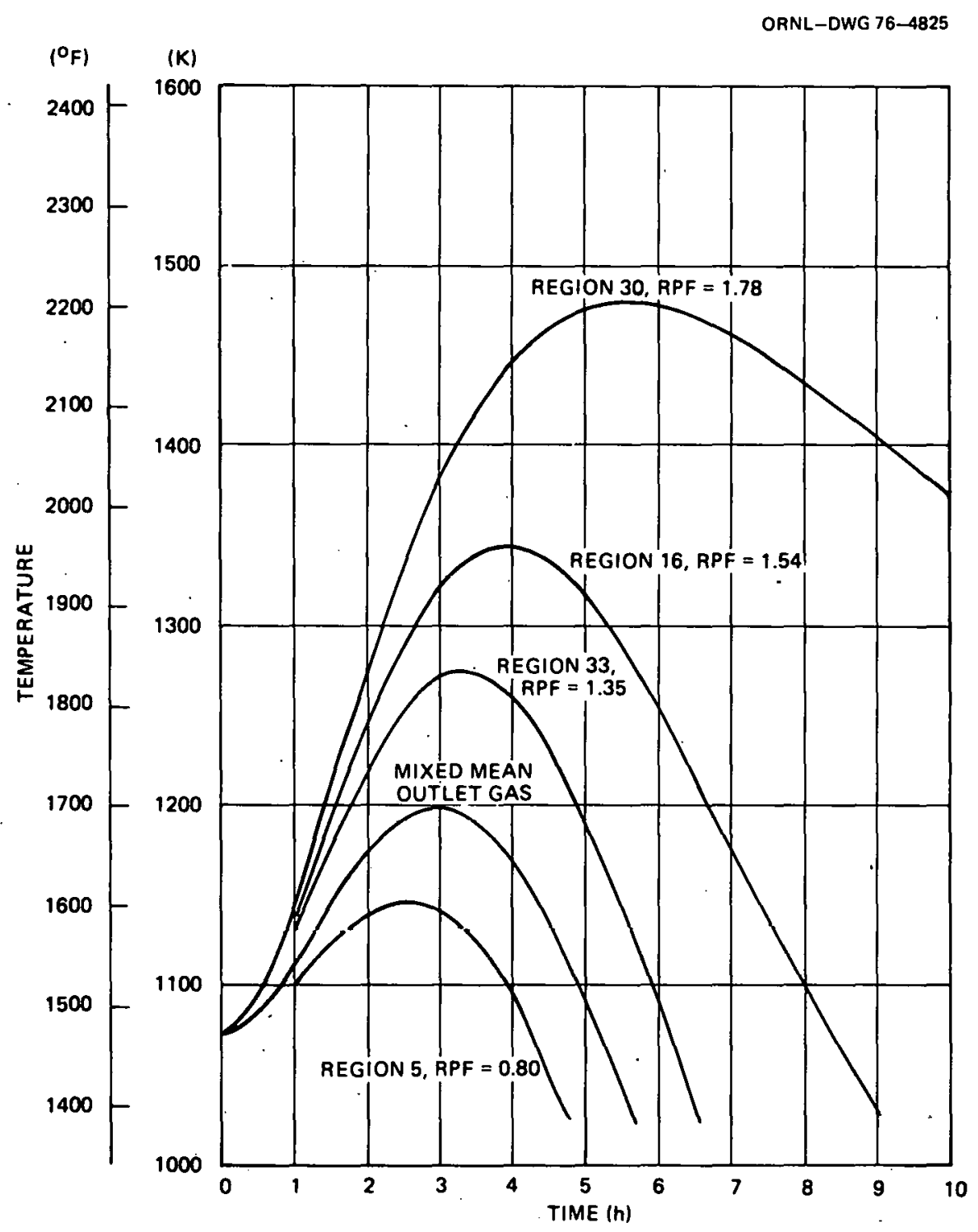

F1g. 10. Refueling region outlet gas temperature following a DBDA. 
sequence only six of the steam generator inlet ducts are providing suction for the circulation of the coolant. Each inlet duct must have roughly the same flow, and thus approximately $6(37 / 6 \approx 6)$ refueling region outlet gas streams must combine to flow down each duct. Figure 11 shows details of the lower plenum arrangement. Before the refueling region streams can combine in the steam generator inlet duct, the outlet gas from each region impinges in a jet on the lower core support floor. From here it spreads out radially, flowing around the core support posts in the lower plenum. Finally, the gas must make a right angle turn to enter the steam generator inlet duct. This process is going to be very conducive to mixing of the gas streams, and one would expect the maximum gas temperature in the steam generator inlet ducts to be near the mixed mean outlet gas temperature of all the refueling regions. Indeed, mixing experiments made by GAC show this to be the case. 36,37 Unfortunately, the results of these studies are not directly applicable to the Fort St. Vrain reactor arrangement or to the flow conditions encountered during operation of the Pelton turbines. Thus, the value listed in Table 5 for the maximum temperature of the steam generator inlet ducts should be considered only as an intelligent guess based on the mixing data of Walker. ${ }^{37}$ Discussions concerning the updating of this mixing data for the Fort St. Vrain reactor have taken place with members of the Nuclear Regulatory Commission.

\section{Conclusion}

Cnnsidering the seriousness of a design basis depressurization accident, the above results show that the thermal response of the Fort St. Vrain reactor and components is satisfactory. The Nuclear Regulatory Commission has made the following licensing decision concerning the Fort St. Vrain reactor: ${ }^{38}$

"... we conclude that the requested reduction of circulator Pelton turbine high speed trip point setting from $10550 \mathrm{rpm}$ to $8800 \mathrm{rpm}$ is acceptable and that (a) because the change does not involve a significant increase in the probability or consequences of accidents previously considered and does not involve a significant decrease in a safety margin, the change does not involve a significant hazards consideration, (b) there is reasonable assurance that the health and safety of the public will not be endangered by operation in the proposed manner, and (c) such 
ORNL-DWG 76-4817

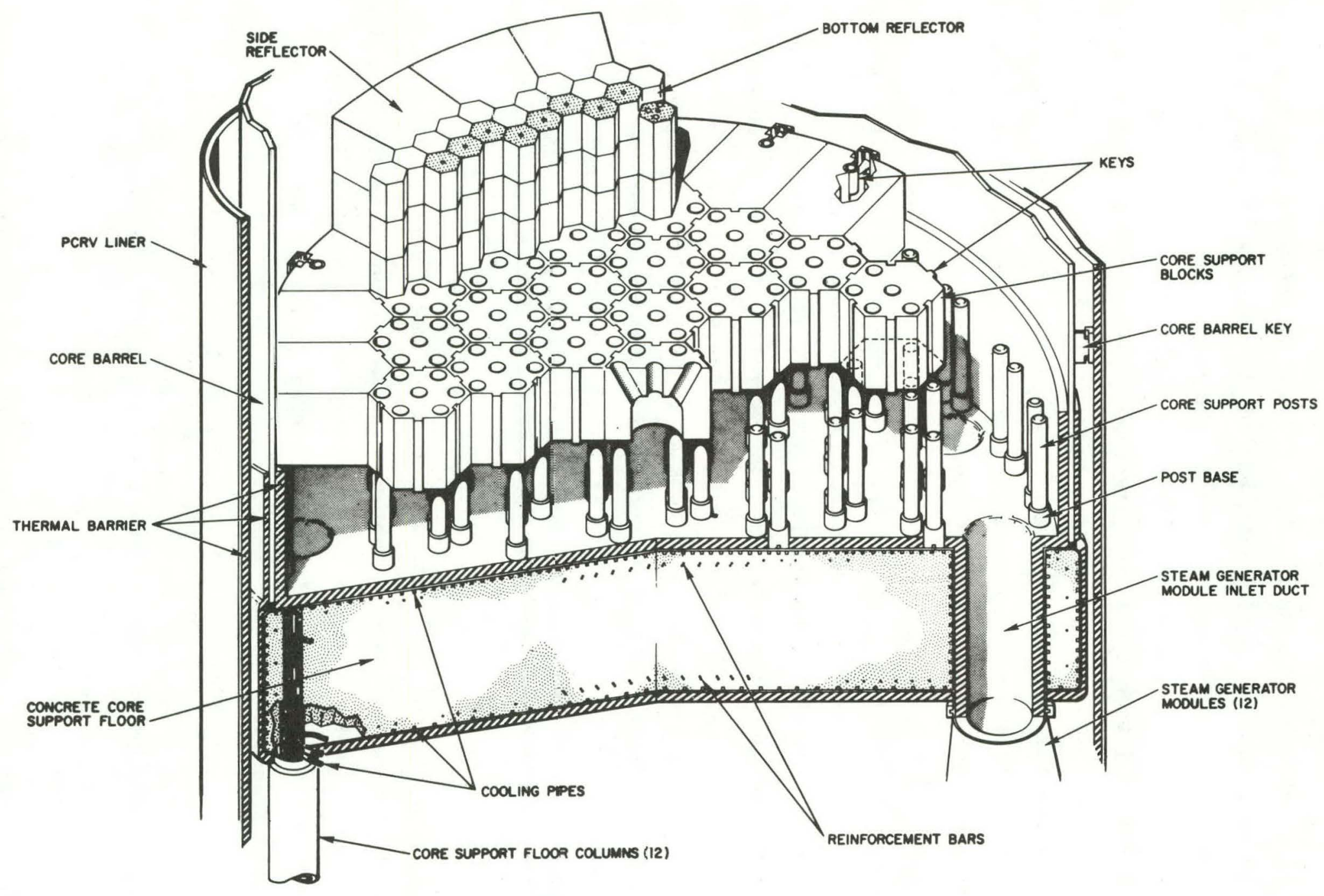

Fig. 11. Lower plenum arrangement. 
activities will be conducted in compliance with the Commission's regulations and the issuance of this amendment will not' be inimical to the common defense and security or to the health and safety of the public." 


\section{REFERENCES}

1. W. D. Turner, CCCM: Coupled Conduction Convection Mode1, ORNL, Computer Sciences Division, (to be published)

2. J. P. Sanders, ORNL, Letter to R. A. Clark, U.S. Nuclear Regulatory Commission (Mar. 21, 1975).

3. J. P. Sanders, W. D. Turner, et al., Evaluation of Thermal Response in Fort St. Vrain Reactor Primary System to a Design Basis Depressurization Accident Followed by Cooling with Two Pelton Wheel Drives Operating at $7000 \mathrm{rpm}$, ORNL/TM-5140 (December 1975).

4. Fort St. Vrain Nuclear Generating Station, Final Safety Analysis Report, Vol. 1, p. 3.1-6.

5. R. F. Walker, Public Service Company of Colorado, Letter to R. A. Clark, Nuclear Regulatory Commission, Docket No. 50-267, p. 16 (Feb. 28, 1975).

6. Fort St. Vrain Nuclear Generating Station, Final Safety Analysis Report, Vol. 1, p. 3.4-17.

7. Ibid. Vol. 1, p. 3.1-8.

8. Ibid. Vol. 1, pp. 1.3-1 to $1.3-4$.

9. Ibid. Vol. 1, pp. 3.1-2 to 3.1-5.

10. R. Bird, Chem. Eng. Sci. 6, 123-131 (1957).

11. R. Bird, W. Stewart and E. Lightfoot, Transport Phenomena, John Wiley \& Sons, Inc., pp. 78-82 (1960).

12. H. Schlichting, Boundary Layer Theory, 6th ed., pp. 562-564, McGrawHill (1968).

13. J. Poiseuille, Récherches expérimentelles sur le mouvement des liquides dans les tubes de très petits diamètres, Compte Rendus 11 , 961-967 and 1041-1048 (1840).

14. H. W. Chi and G. J. Malek, Description of the Reactor Emergency Cooling Analysis Code, RECA, GA-10273 (August 1970).

15. J. Crank and P. Nicholson, "A Practical Method for Numerical Evaluation of Solutions of Partial Differential Equations of the Heat Conduction Type," Proc. Comb. Phil. Soc: 43, pp. 50-67 (1947).

16. G. D. Smith, Numerical Solution of Partial Differential Equations, Oxford University Press, pp. 24-27 (1965). 
17. T. B. Drew, E. C. Koo and W. H. McAdams, "The Friction Factor for Clean Round Pipes," Trans. Am. Inst. Chem. Eng. 28, 56 (1932).

18. M. E. Davenport and P. M. Magee, Heat Transfer and Pressure Drop for a Gas at High Temperature, Tech. Report No. 247-2, The Nuclear Technology Laboratory, Stanford University, Stanford, Calif. (May 1961).

1.9. G. Hagen, Ann. Phys. Chem. 46, 423-442 (1839).

20. W. M. Kays, "Loss Coefficients for Abrupt Changes in Flow Cross Section with Low Reynolds Number in Single and Multiple Tube Systems," Trans. ASME, 72, 1067-1074 (1950).

21. H. Rouse, Elementary Mechanics of Fluids, John Willey \& Sons, New York, N. Y. P. 57, 1946 .

22. E. Sieder and C. Tate, "Heat Transfer and Pressure Drop of Liquids in Tubes," Ind. Eng. Chem., Vol. 28, p. 1429 (1936).

23. W. McCabe and J. Smith, Unit Operations of Chemical Engineering, pp. 449-452, McGraw-Hil1, 1956.

24. V. Joksimovic, et a1., An Analysis of HTGR Core Cooling Capability, GA-LTR-1, Gulf-GA-A12504, pp. 5-15 (Mar. 30, 1973).

25. H. Peterson, The Properties of Helium: Density, Specific Heats, Viscosity, and Thermal Conductivity at Pressures from 1 to 100 Bar and From Room Temperature to about $1800 \mathrm{~K}$, Risö Report No. 224 (September 1970).

26. J. M. Wright, Calculated Thermal Conductivities of Pure Gases and Gaseous Mixtures at Elevated Temperatures, AECD-4197, General Electric Corp., Hanford Works (1951).

27. "Thermophysical Properties of Refrigerants," American Society of Heating, Refrigerating, and Air Conditioning Engineers (1973).

28. J. R. Tallackson, The Thermal Transport Properties of Helium, HeliumAir Mixtures, Water, and Tubing Steel Used in the CAHE Program to Compute HTGR Auxiliary Heat Exchanger Performance, ORNL/TM-4931 (February 1976).

29. J. P. Sanders, Physical and Thermodynamic Properties of Helium to he Used in Performance Evaluation of Gas-Cooled Reactors, IntraLaboratory Correspondence, ORNL (November 20, 1972).

30. M. P. Wilson, Thermodynamic and Transport Properties of Helium, GA-1355 (January 1960).

31. Forl 3t. Vrain Nuclear Generating Station, Final Safety Analysis Report, Vol. 1., p. 3.6-5, Public Service Company of Colorado, Denver, Colorado. 
32. W. D. Turner and I. I. Siman-Tov, "Thermal Analysis and Code Development," HTGR Safety Studies Progr. Rep., June 20, 1973, Pp. 4-15, ORNL/TM-4741 (GCR-DL: 73-3).

33. W. D. Turner and I. I. Siman-Tov, "Thermal Analysis and Code Development," HTGR Safety Studies Progr. Rep., Mar. 31, 1973, pp. 2-5, ORNL/ TM-4753 (GCR-DL: 73-2).

34. Investigation Into the Cause and Consequences of the Fort St. Vrain Pelton Wheel Incipient Fractures, General Atomic Company, GA-Al3175, (October 1974).

35. R. F. Walker, Public Service Company of Colorado, Letter to

R.A. Clark, NRC, Docket No. 50-267 (Feb. 28, 1975).

36. E. Chin and H. Keller, $3000 \mathrm{MW}(\mathrm{t})$ Primary Coolant Flow Test Programs, General Atomic Company, GA-A12762 (Feb. 1, 1974).

37. W. E. Walker, PSC Region I Flow Model (Series 2) Test Report, GAMD8625 (July 8, 1965).

38. Safety Evaluation By the Office of Nuclear Reactor Regulation Supporting Amendment No. 9 to Facility Operating License No. DPR-34, Public Service Company of Colorado, Fort St. Vrain Nuclear Generating Station, Docket No. 50-267, pp. 12-13, (February 1976). 
APPENDIX A

This appendix contains information concerning the setup and use of the FLODIS code. Table A.1 contains the definitions of variables used as input to the code. Table A. 2 has the complete FORTRAN IV listing of the FLODIS program. Table A.3 lists a set of sample input data cards for the Fort St. Vrain DBDA. All input is in namelist format. Note that most of the code input and output is given in English units instead of SI units. The reason is that the code was written before SI units came into general use at ORNL; also the specifications for the Fort St. Vrain reactor design are given in the English system of units. 
Table A.1 Definitions of FLODIS input variables

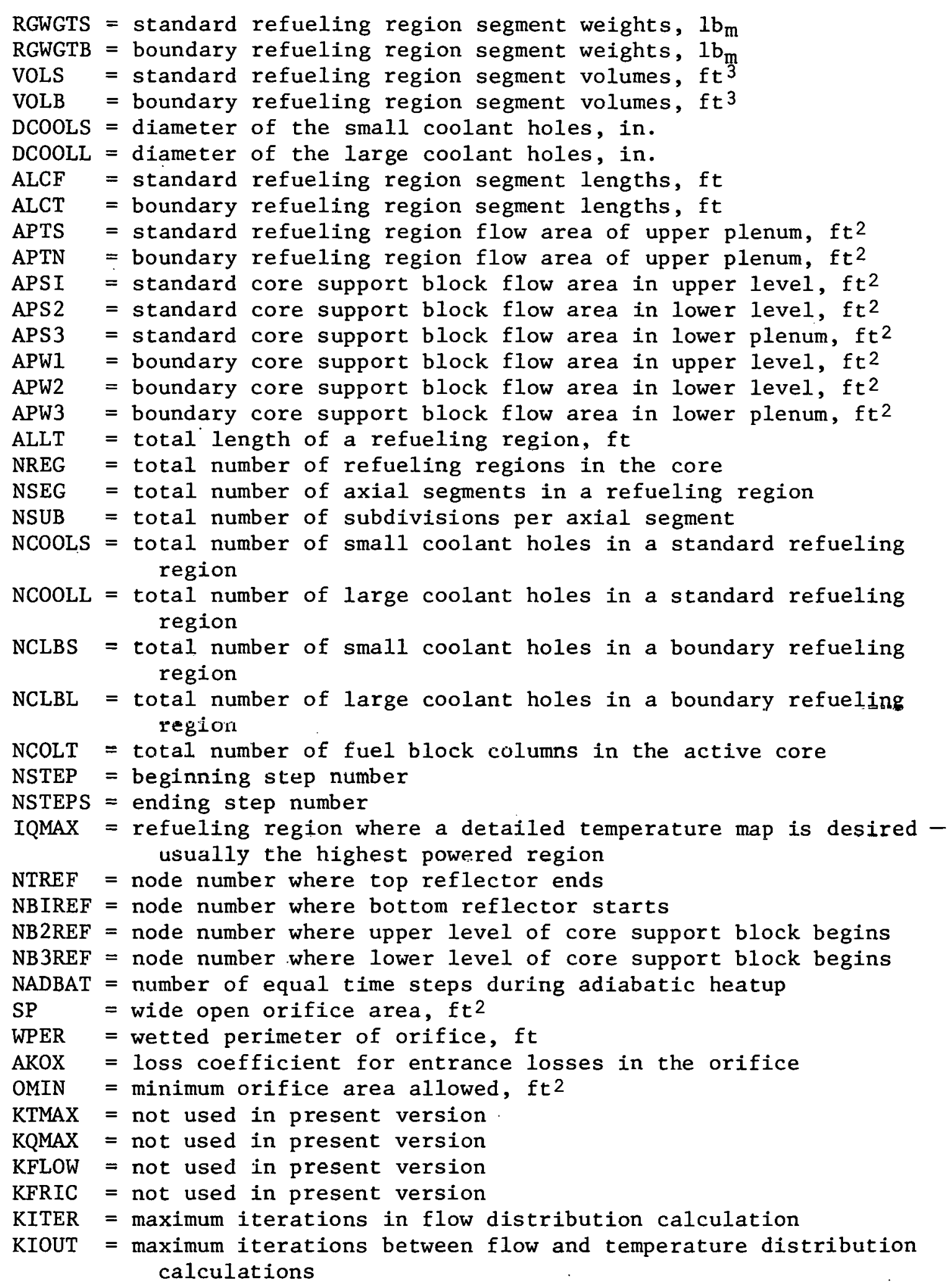


Table A.1 (continued)

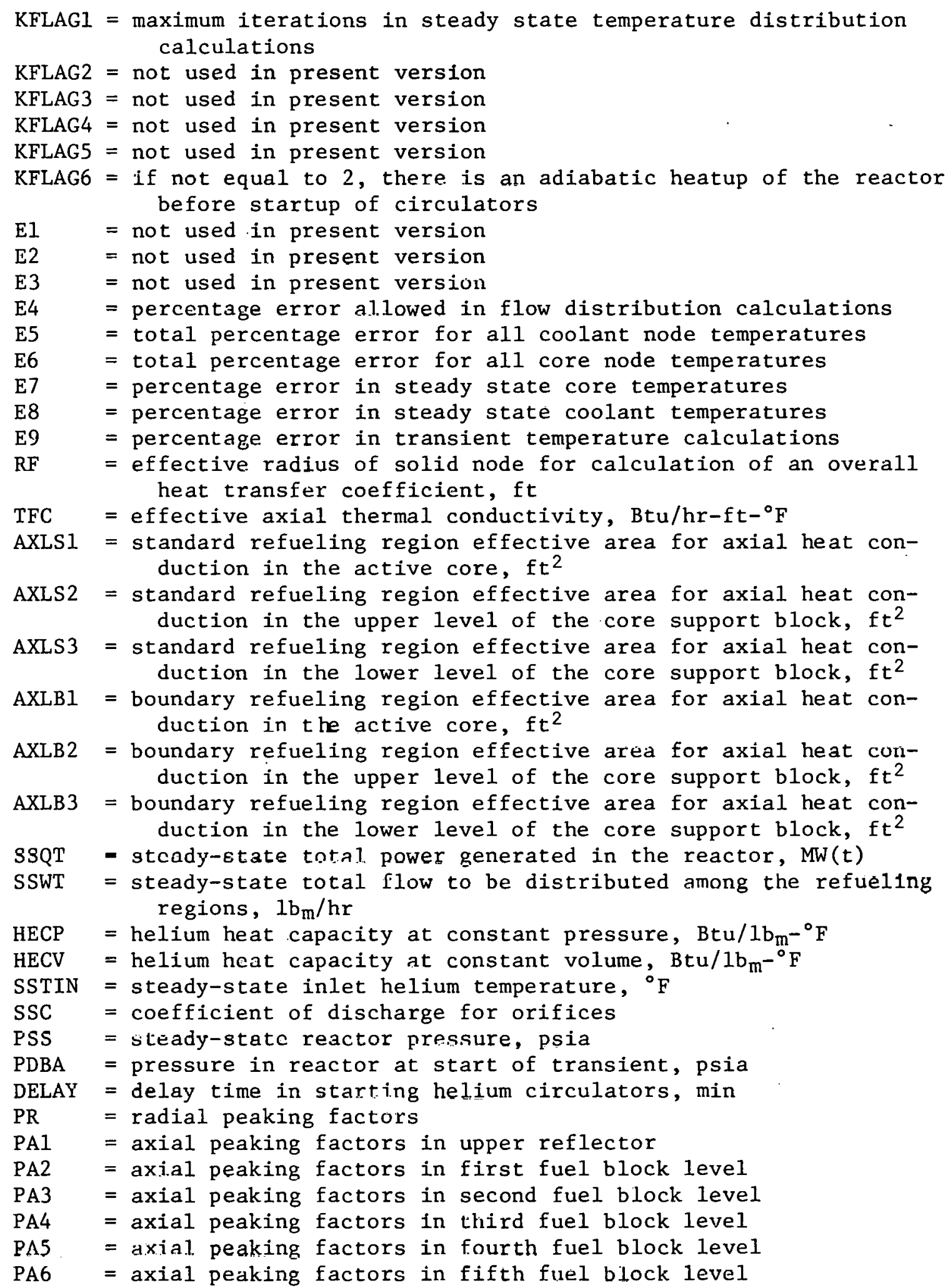


Table A.I (continued)

PA7 = axial peaking factors in sixth fuel block level

DPT = hydraulic diameter of refueling region of upper plenum, ft

DBI = hydraulic diameter of upper level of core support block, $\mathrm{ft}$

DB2 = hydraulic diameter of lower level of core support block, ft

DB3 = hydraulic diameter of lower plenum, ft 


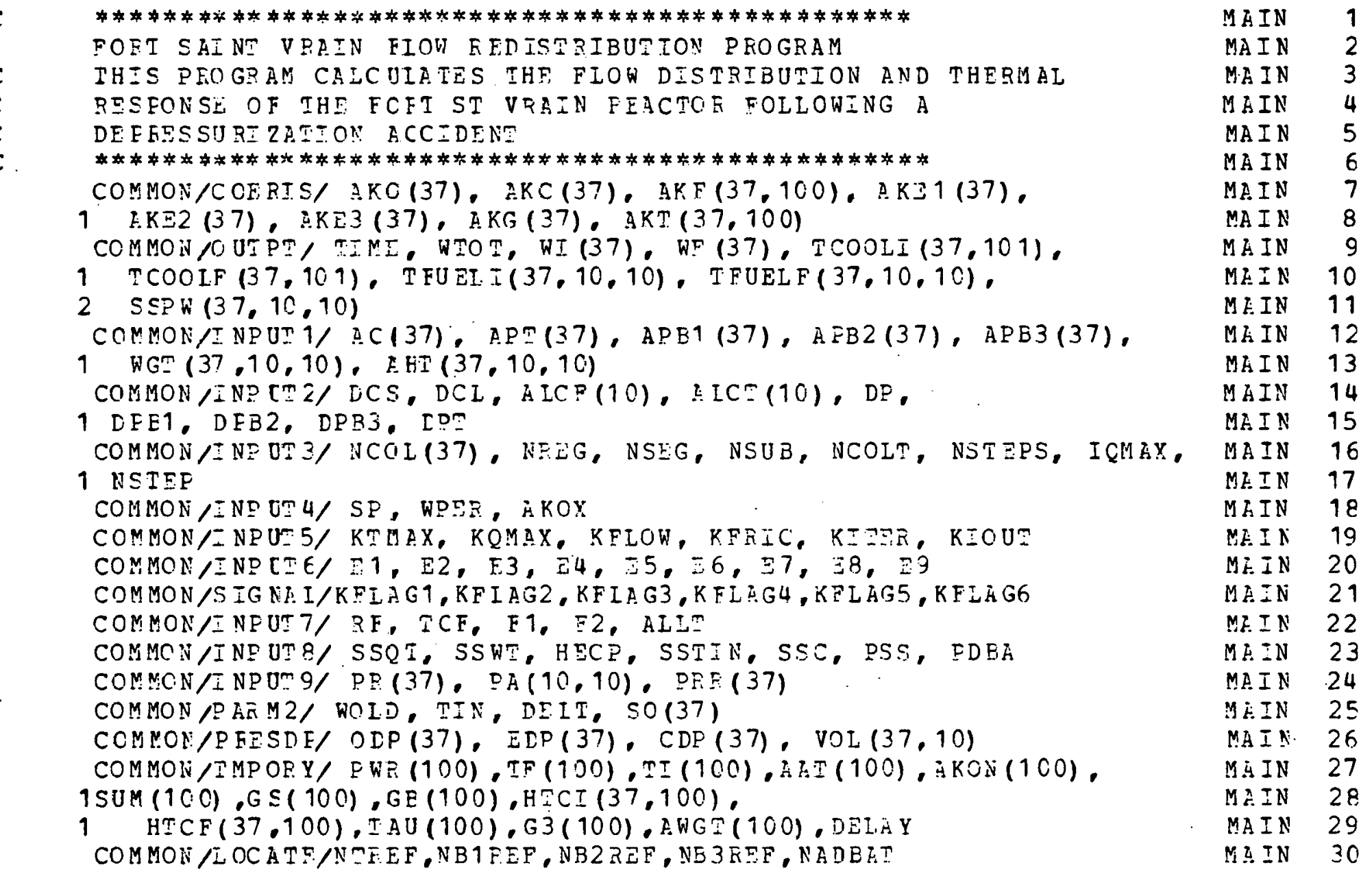




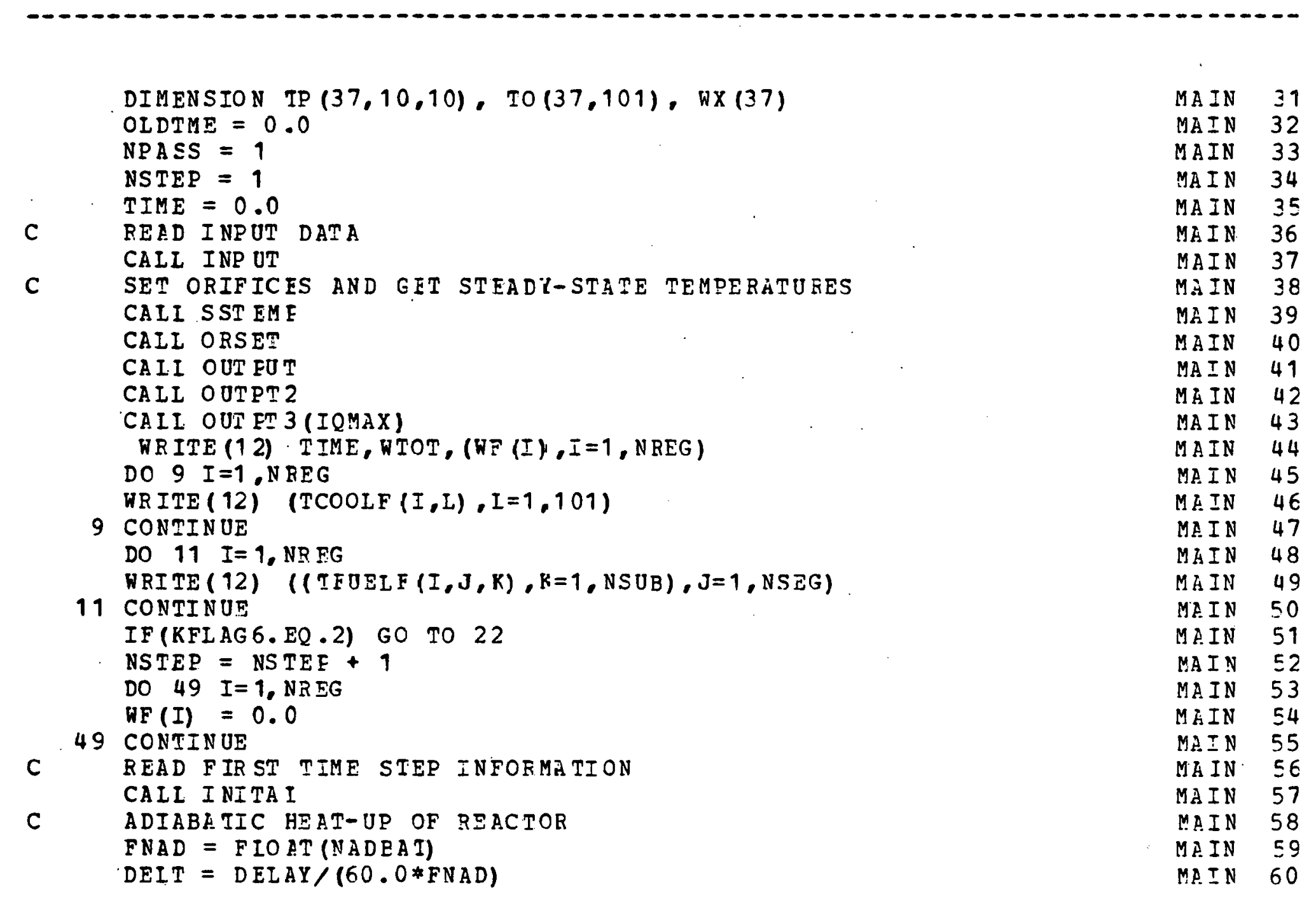


Table A.2 (continued)

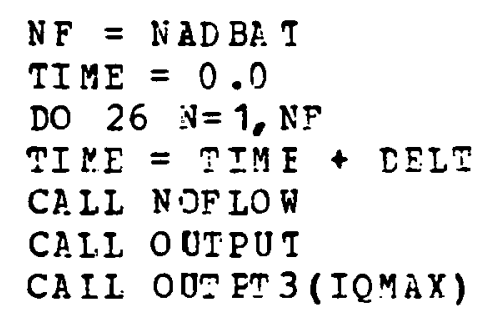

$\begin{array}{ll}\text { MAIN } & 61 \\ \text { MAIN } & 62 \\ \text { MAIN } & 63 \\ \text { MAIN } & 64 \\ \text { MAIN } & 65 \\ \text { MAIN } & 66 \\ \text { MAIN } & 67 \\ \text { MEIN } & 68 \\ \text { MAIN } & 69 \\ \text { MEIN } & 70 \\ \text { MAIN } & 71 \\ \text { MAIN } & 72 \\ \text { MAIN } & 73 \\ \text { MAIN } & 74 \\ \text { MAIN } & 75 \\ \text { MAIN } & 76 \\ \text { MAIN } & 77 \\ \text { MAIN } & 78 \\ \text { MAIN } & 79 \\ \text { MAIN } & 80 \\ \text { MAIN } & 81 \\ \text { MAIN } & 82 \\ \text { MAIN } & 83 \\ \text { MAIN } & 84 \\ \text { MAIN } & 85 \\ \text { MAIN } & 86 \\ \text { MAIN } & 87 \\ \text { MAIN } & 88 \\ \text { MAIN } & 89 \\ \text { MAIN } & 90\end{array}$




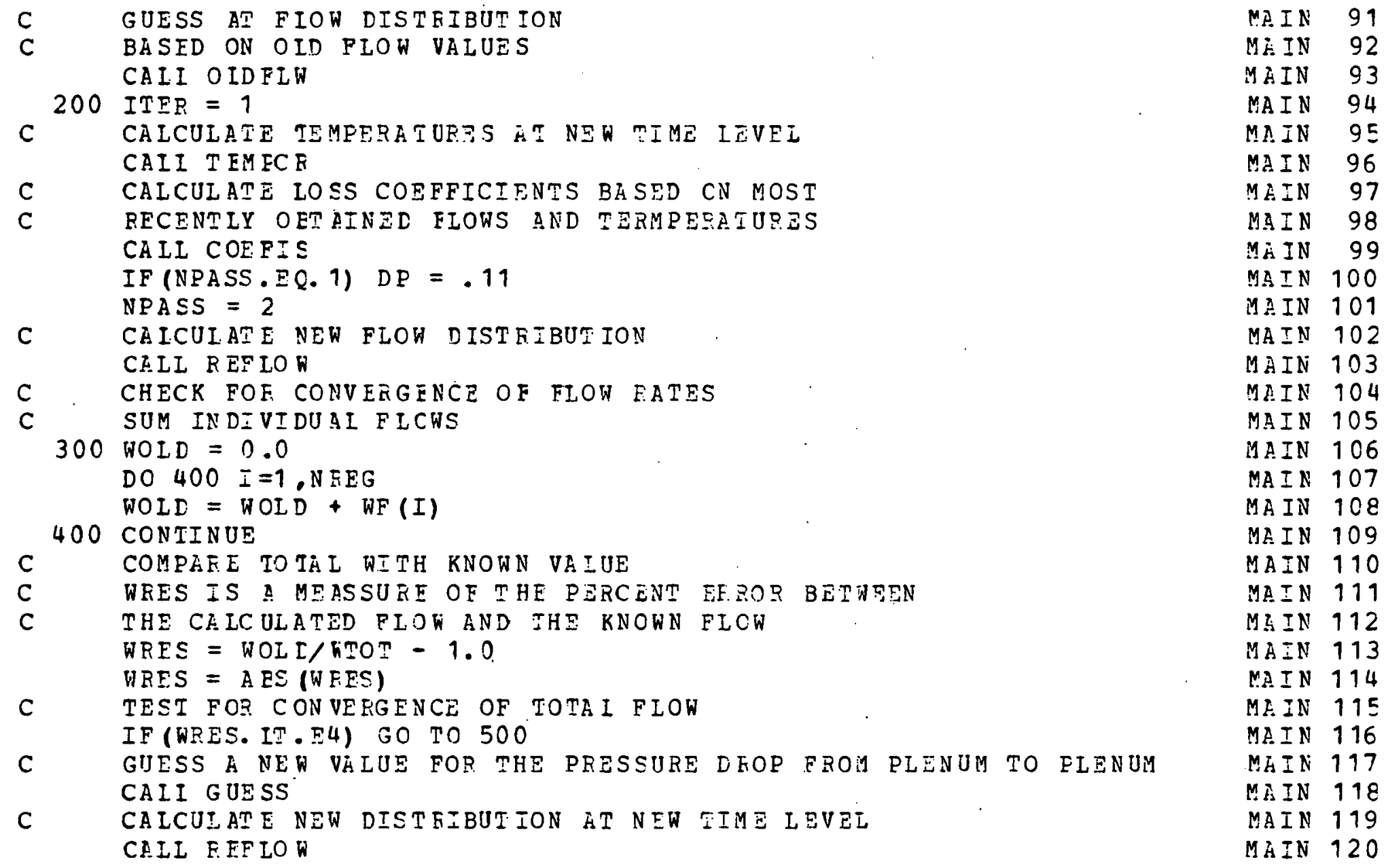


Table A.2 (continued)

$I T E F=I T F R+1$

MEIN 121

C

CHECK TO SFE IF THE MAXIMUM NUMBER OF ITESATIONS HZVE BEEN EXCEEDEMAIN 122

IF (ITER. LE.KITEP) GO TO 300

MAIN 123

WRTTE $(6,911) \quad K=T E:$

MATN 124

911 FOPMAT (1OX,'SOIUTICN FAILED TO CONVHEGE AFTEE, I3,' ITEKATONS'// MAIN 125

1 10X,"THE UNCONVERG SOIUTZON IS")

CAII OUTEU:-

CHII OUIPT 2

CEI: OU:PT 3 (IQMAX)

STOE

C OUTEE LOOP CON VERGENCE

IYIS IOOP CHECKS FOR CONVFRGENCE BEOWEN OUDER LOOP ITETATIONS

TWO CEITEE IL MUST RE MEI-OTHE FIOWS GND TEMFEREIUES CAN NOT

CHANGE BY YORE THAN SOME EPSILON BET WEEN OUTER LOOF ITESATICNS

MAIN 127

MAIN 128

MiLIN 129

MAIN 130

MEIN 131

MAIN 132

MAIN 133

MIIN $1-34$

THIS ZS ANHIAGOUS TO A PZEDICTOR-COFFECTOR METHOD

CHECK FOF CONVERGËNCE OF TEMEFRATUEF

500 IF (ICUT. EQ.1) GO :C 620

DO $605 i=1$, NFEG

MEESW $=A B S(W F(I) / T X(I)-1.0)$

IF (TEESW.GT. E4) GC IO 610

605 CONTIN OE.

IFESC $=0.0$

TEESF $=0.0$

DO $600 Z=1$, N FEG

DO $595 \mathrm{~J}=1$, N SEG

DO $590 \quad K=1, N \leq U B$

MAIN 135

MEIN 136

MAIN 137

$M E I N 138$

MLIN 139

MIIN 140

MEIN 141

MAIN 142

MAIN 143

MEIN 144

M.IN 145

$I=(\mathrm{J}-1) * \mathrm{NSUB}+\mathrm{K}$

$N C=I+1$

MIIN 146

MiIN 147

TEMFX $=\operatorname{ABS}(T P(I, J, K) / T F U E L F(I, J, K)-1,0)$

M.IN 148

C

TRESF IS THE EERCENT EFROR IN THF FUEL TEMEZRRTURES EETWEEN ETERETMRIN 150 


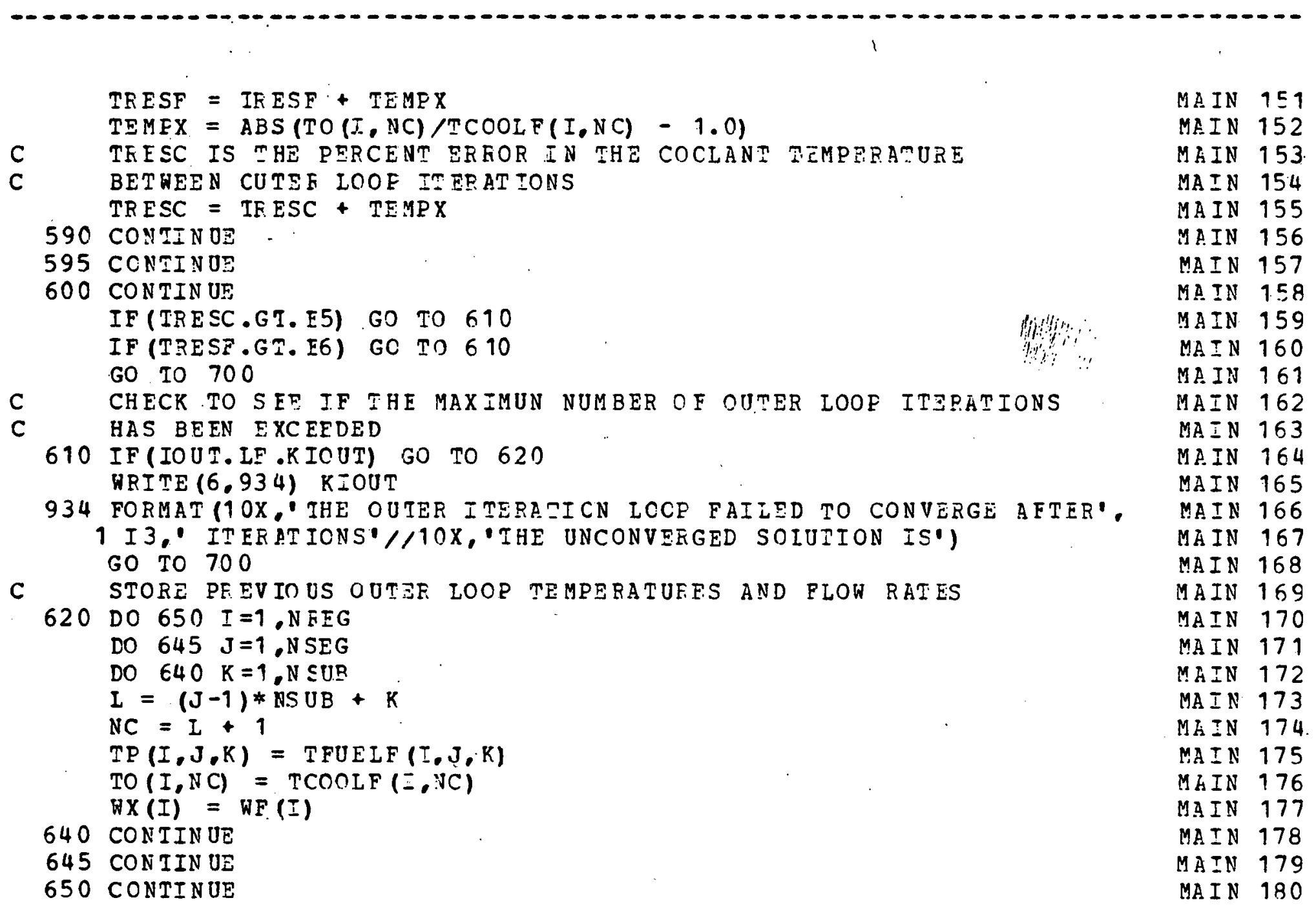

MAIN 151 MEIN 152

MAIN 153

MAIN 154

MAIN 155

MAIN 156

MAIN 157

MAIN 1.58

MAIN 159

MAIN 160

MAIN 161

MAIN 162

MA IN 163

MA.IN 164

MAIN 165

MAIN 166

MAIN 167

MAIN 168

MAIN 169

MAIN 170

MAIN 171

MAIN 172

MAIN 173

MEIN 174.

MAIN 175

MAIN 176

MAIN 177

MAIN 178

MAIN 179

MAIN 180 


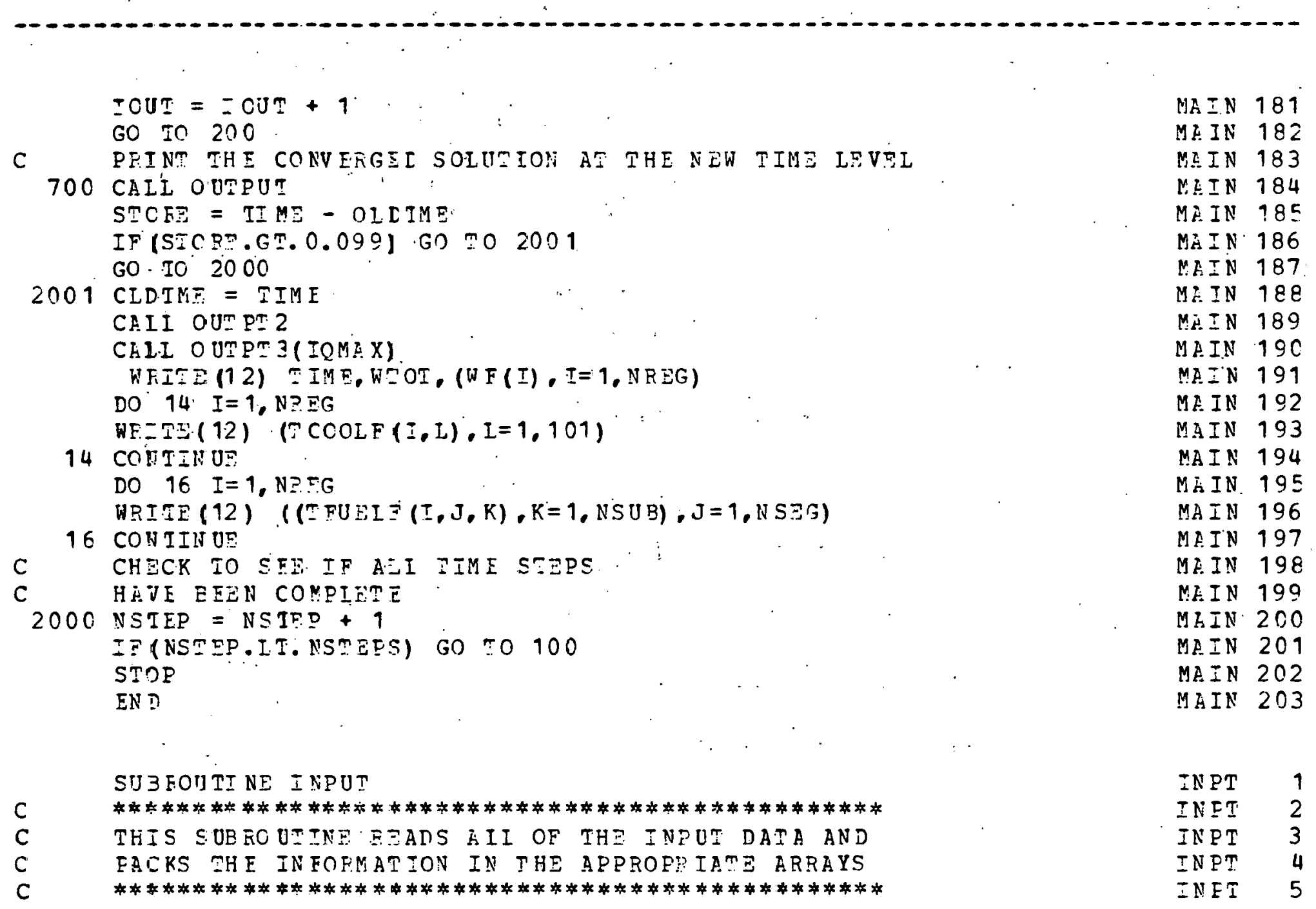

NAIN 181

MIIN 182

MIIN 183

MEIN 184

MEIN 985

MAIN 186

MEIN 187

MI. IN 188

MEIN 189

MAIN 190

MAIN 191

ME. IN 192

MAIN 193

MAIN 194

MEIIN 195

MAIN 196

MEIN 197

MEIN 198

MEIN 190

MEIN 200

MAIN 201

MAIN 202

MEIN 203

$\begin{array}{ll}\text { INPT } & 1 \\ \text { INET } & 2 \\ \text { INPT } & 3 \\ \text { INPT } & 4 \\ \text { INET } & 5\end{array}$


COMMON COERIS/ AKO (37), ZKC (37), AKF $(37,100), A K E 1(37)$,

INFT 8

INET 9 
Takle A.2 (continued)

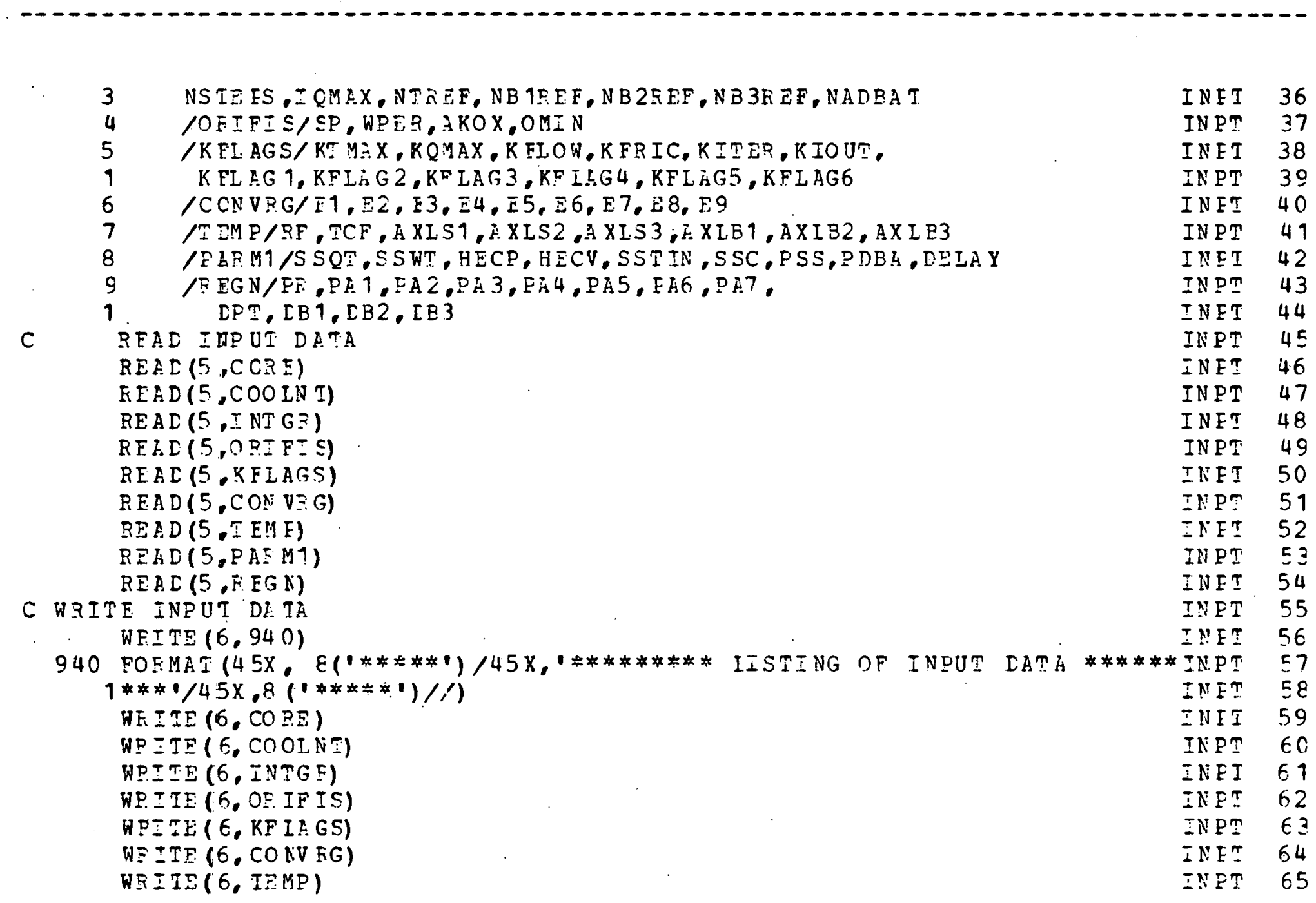




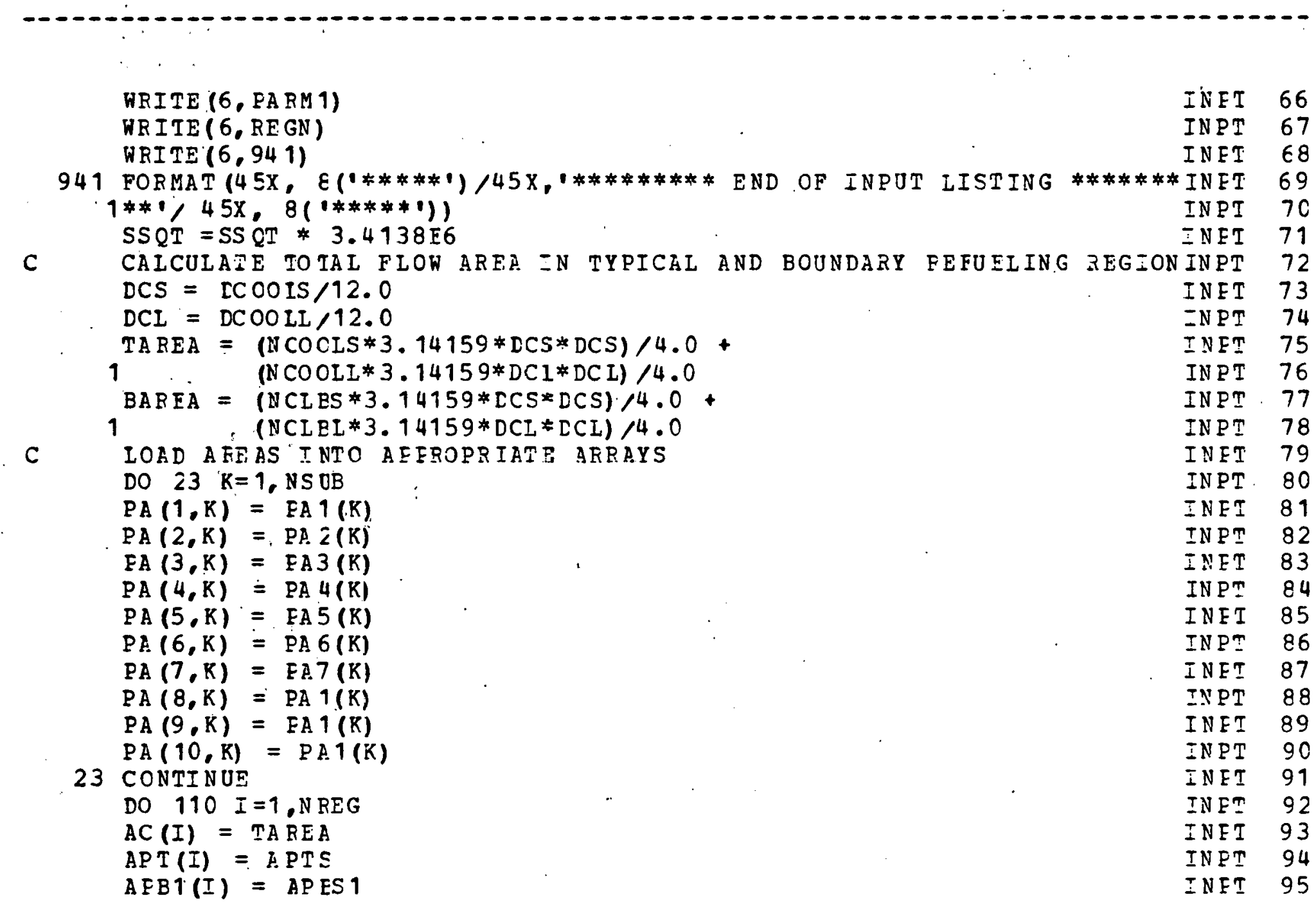


Tablè ม.2 (cortinued)

$\operatorname{APE} 2(\bar{i})=\operatorname{AFES} 2$

$\operatorname{APE} 3(I)=$ ADES3

110 CONTINUE.

$A C(20)=B A R E$

$A C(23)=B A P E A$

$A C(26)=B . ? I E$

$A C(29)=B P E A$

$A C(32)=B A E A$

$A C(35)=B A R E$

$\operatorname{APT}(20)=A D T W$

$A E T(23)=A D T W$

APT $(26)=A P T W$

APT (29) = APTW

$\operatorname{AET}(32)=\operatorname{ADTW}$

APT (35) = APTW

DO $120 I=1, N E E G$

DO $119 \cdot J=1, N \leq F G$

AMASS = FGHGTS $(J) / N S U B$

DO $118 \mathrm{~K}=1$, $\mathrm{N} S U B$

WGI $(I, J, K)=$ RMSS

118 CON IIN UE

119 CCNTENUE

120 CONINUE

DO $125 \mathrm{~J}=1, N S E G$

AMASS = RGWG E B (J)/NSIJ

DC $124 \mathrm{~K}=1, \mathrm{~N} \leq \mathrm{UE}$

WG $:(20, J, K)=Z N G S S$

$W G I(23, J, K)=$ MM $S S$

WG $\mathbf{I}(26, J, K)=A H \dot{E} S S$

WGT $(29, J, K)=i$ MESS

INET 96

INPT 97

INET 98

INPM 99

INET 100

INPI 101

INET 102

IN PT 103

INET 104

INPT 105

I!NP? $10 \mathrm{E}$

INET 107

INPT 108

INET 109

INPT 110

INET 111

INET 112

ENET 113

IN PT 114

INET 115

INPT 116

INPT 117

INET 118

INDT 119

INET 120

INPT 121

INET 122

INET 123

INET 124

INET 125 


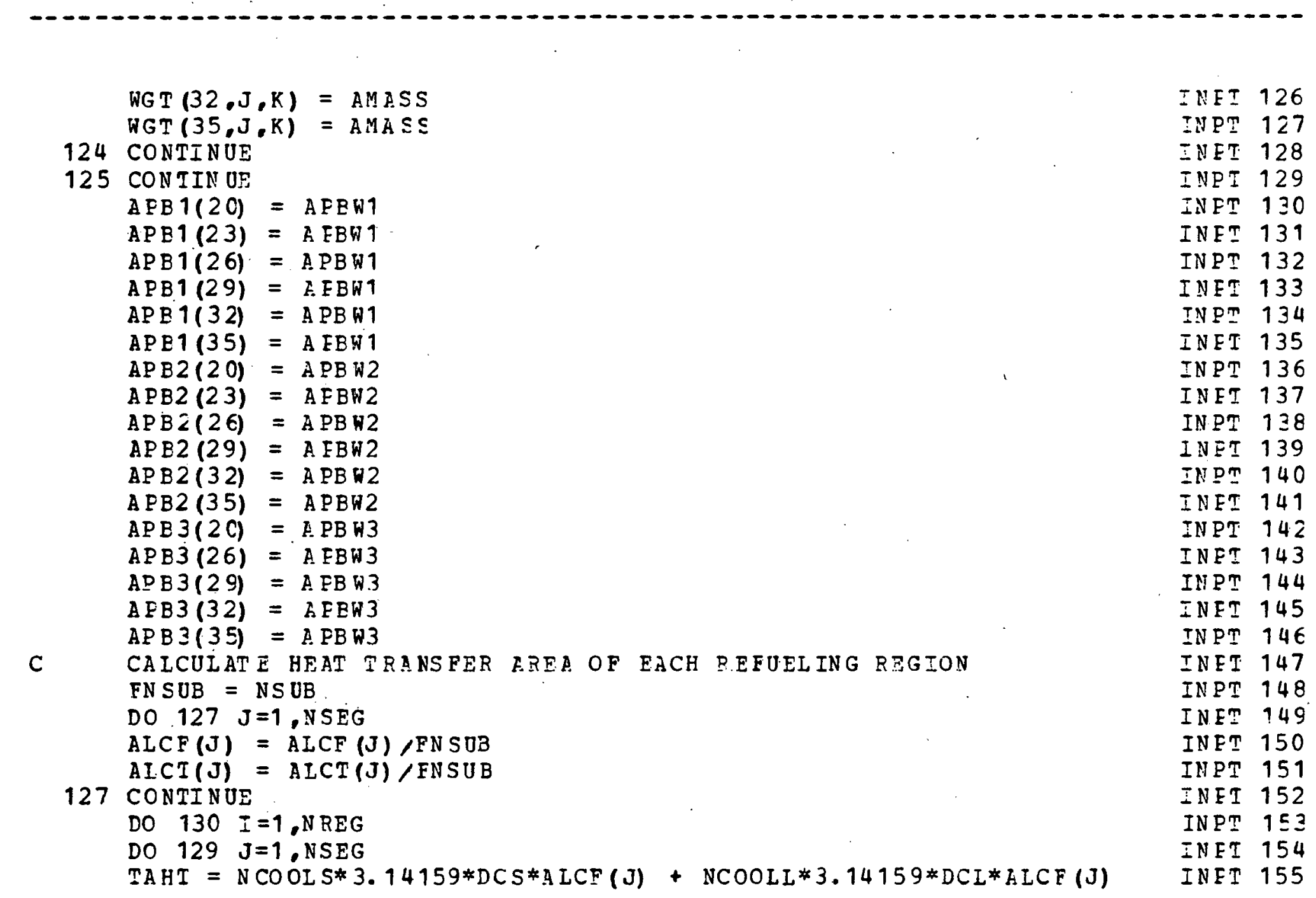


Table h.2 (continued)

DO $128 \mathrm{~K}=1$, N $S \mathrm{UE}$

$A H T(I, J, K)=T A H T$

128 CONTIil U:

129 CONTINUP

130 CONIINUP

DO $135 \mathrm{~J}=1, \mathrm{NSEG}$

EAHI = NCIBS*3.14159*DCS*hICF(J) + NCIBI*3.14159*DCL*ALCF (J)

DO $134 \quad K=1$. $P$ SIJ $P$

$A H T(20, J, K)=B A B T$

$A H T(23, \mathrm{~J}, \mathrm{~K})=\operatorname{BLHT}$

$A H T(26, J, K)=B A B T$

A HT $(29, \mathrm{~J}, \mathrm{~K})=\mathrm{BH} H \mathrm{H}$

A. T T $(32, \mathrm{~J}, K)=$ BA.ET

$A H T(35, J, K)=B h H T$

134 CONTIN U:

135 CONTINUF

C

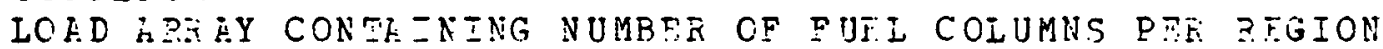

DC $140 I=1, N F E G$

$\operatorname{NCOI}(I)=7$

140 CONIIN UE.

$\operatorname{NCCI}(20)=5$

$\operatorname{NCOI}(2 \vdots)=5$

$\operatorname{NCOI}(26)=5$

$\operatorname{NCCI}(29)=5$

$\mathrm{NCOI}(32)=5$

$\operatorname{NCOI}(35)=5$

DC $210 \quad I=1, N R T G$

DO $205 \mathrm{~J}=1$. NSEG

$\operatorname{VOI}(I, J)=\operatorname{VOLS}(J)$

205 CON IIN UE

IN PT 156 INET 157

INPT 158

IN FI 159

INFT 160

INPT 161

INPT 162

IN PM 163

INET 164

INPT 165

INET 156

IN PT 167

INPT 168

INET 169

INPT $17 \mathrm{C}$

INET 171

INPT 172

IN PT 173

INET 174

INPT 175

INET 176

INPT 177

INPT 178

INEI 179

INET 180

INFT 181

INPT 182

INET 183

INET 184

INIPT 185 


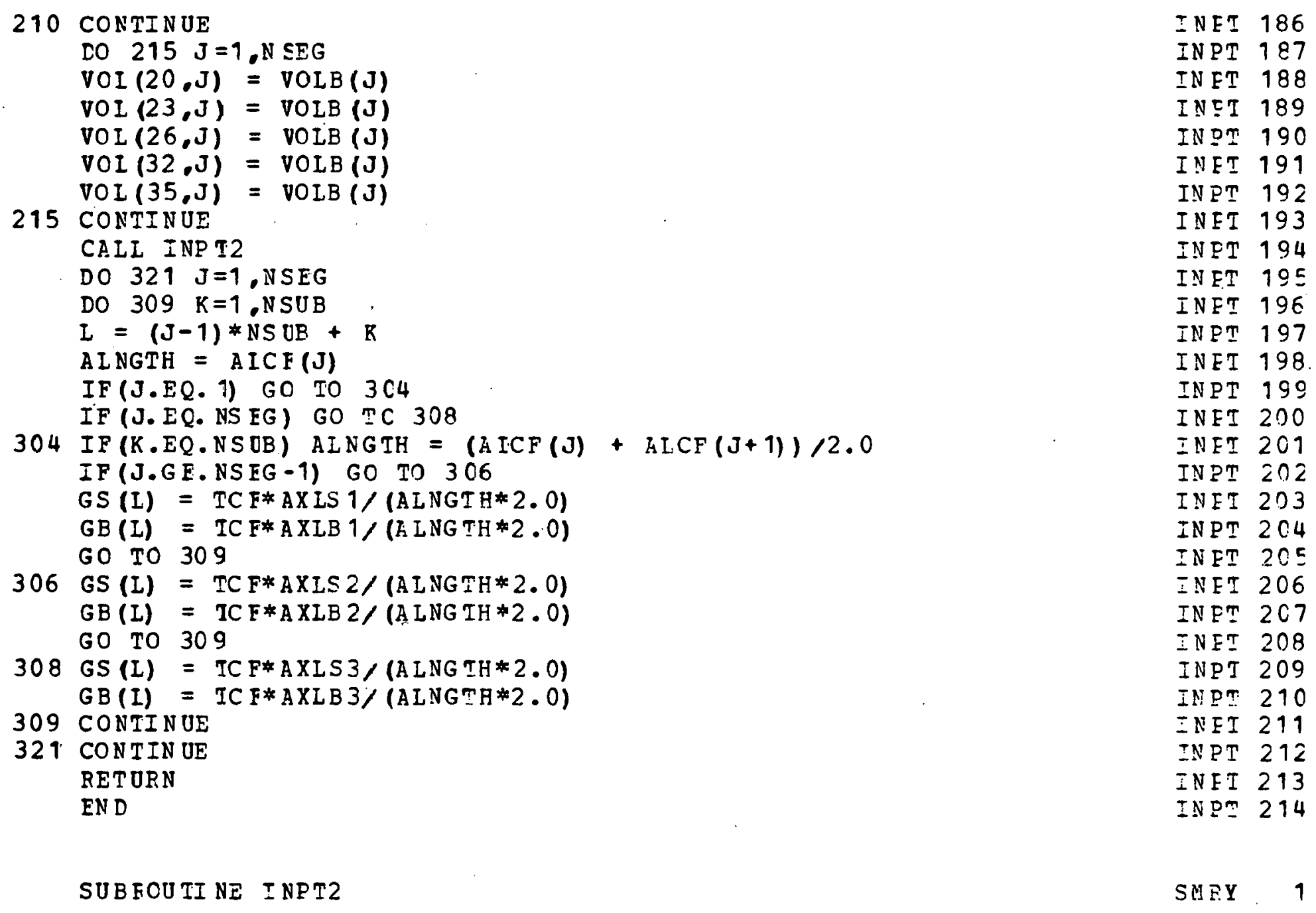




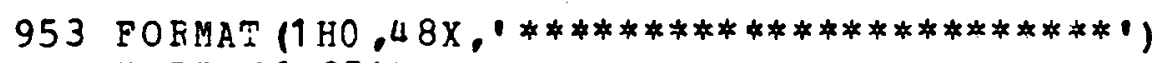
WRITE ( 6,954$)$

954 FORMAT $(49 \mathrm{X}, * *, 22 \mathrm{x}, * 1)$ NRITE $(6,1953)$

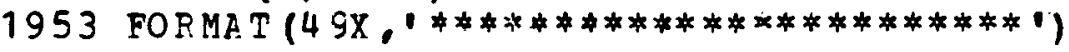
HRITE $(6,957)$ WRITE $(6,957)$

955 FOFMAT $(50 \mathrm{X}, * .20 \mathrm{*}, * 1)$

HRTTE $(6.955)$

ORMAX $=1.7501$

HRITE $(6.956)$ ORMRX.

956 FOPMAT $76 \mathrm{X}$. WIDE CPEN OEIFICE'/76X,'APEA =',F7.4.'SQ FT') WRITE $(6,954)$

WRITE $(6,961)$ SP

957 FORMAT $\left(49 X_{,} * * 1,20 X, * * 1\right)$

HRITE $(6,957)$

HRTTE $(6,955)$

WRITE $(6, \subsetneq 5 \varepsilon)$

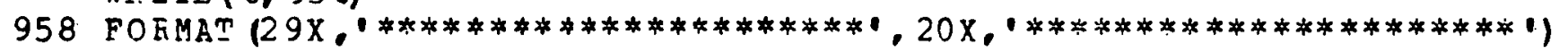
HRITE $(6,959)$

959 FOFMAT $(29 X, * 1.62 X, \cdots *)$

WFITE $(6,959)$

WPITE $(6,960)$ AET $(30)$

960 FCRMAT (29X, * "9X, 'KEEUELING REGION PIENUM AREA ='。 1 F7.5.'SQ FT'.10X,**)

961 FORMAT $(49 X, * *$ OEIFICE CYIENDER **1/49X,** 1 SQFT:"**1)

VRITE $(\epsilon, 95$ C)

WRITE $(6,959)$

NPITE $(6,96$ z)

SMFY 32

SMEY 33

SMRY 34

SMEY 35

SMEY 36

SMRY 27

SMEY 38

SMRY 39

SMEY $4 \mathrm{C}$

SMEY 41

SMRY 42

SMEY 43

SMRY 44

SMGY 45

SMRY 46

SM RY 47

SMEY 48

SMRY 49

SMEY 50

SMEY 51

SMRY 52

SMEY 53

SMEY 54

SMEY 55

SMSY 56

SM KY 57

SMEY 58

SUतY 59

SMRY 60

SMRY 61 
Table i.2 (continuen)

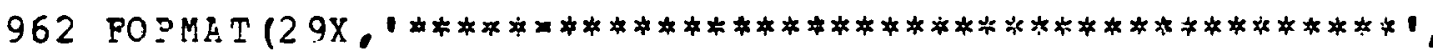

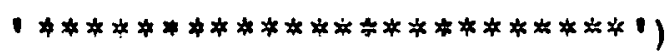
WF $=T E(6,963)$

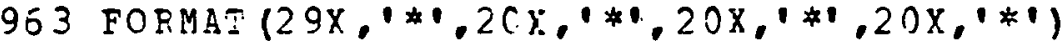

WIITE $(6,96.3)$

WE. ITE ( 6,963$)$

WRITE $(6,959)$

WEITE $(6,964)$

964 FOFMIF $(29 X .10 .198 .120$ P R E F I F C T O

WFITE (E, 95 C)

WRITE $(6,965)$

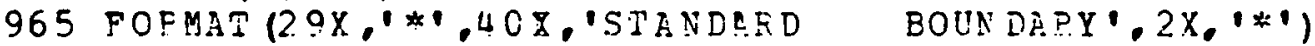

WP. ITE $(6,95 \subseteq)$

$I S=3 C$

$I B=23$

HETTE $(6,966)$ NCOI(IS), NCOL (IE)

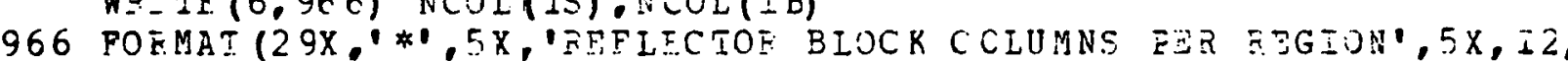

$110 X, I 2,4 X, * 1)$

$L S \equiv G=1$

WPITE ( 6,967$) \quad I, S E G, I S I G$

SMEY

SMFY 66

SMEY 67

SMEY 68

SMEY 69

SMPY 70

SMRY 71

SMRY 72

SMEY 73

SMEY 74

SMPY 75

SMEY 76

SMEY 77

SMEY 78

SMEY $7 C$

SMEY 80

SMSY Q 1

967 FOPMAT (29X.'*0,5X.'NUMEFE OF AYTEL SEGM ENTS'.T75,I2,10X, I2,4X,1*1) SMFY 82 WPITE $(6,968)$ NSUD, NSUB

SMEY \&3

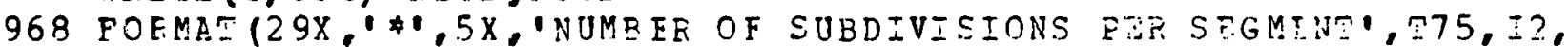
$110 x . \pm 2,4 \times, * 11$ WEITE (6,959)

WRITE (6,969) AC(3D), AC(23)

969 FOEMAT (29X, *.5X, FLON FREA (SQ FI) ', :73,F7.4,4X,F8.4,1X, *1) HEIIE $(6,970)$ I HE $(30,1,1)$, AHI $(23,1,1)$

970 FOEMAI (29X,'*1,5X, 'HEẼ IRANGFR ARFR PER INODE (SQ FE)'。 $1972, F 8,4,4 X, F 8.4,1 X, 1 * 1$ 


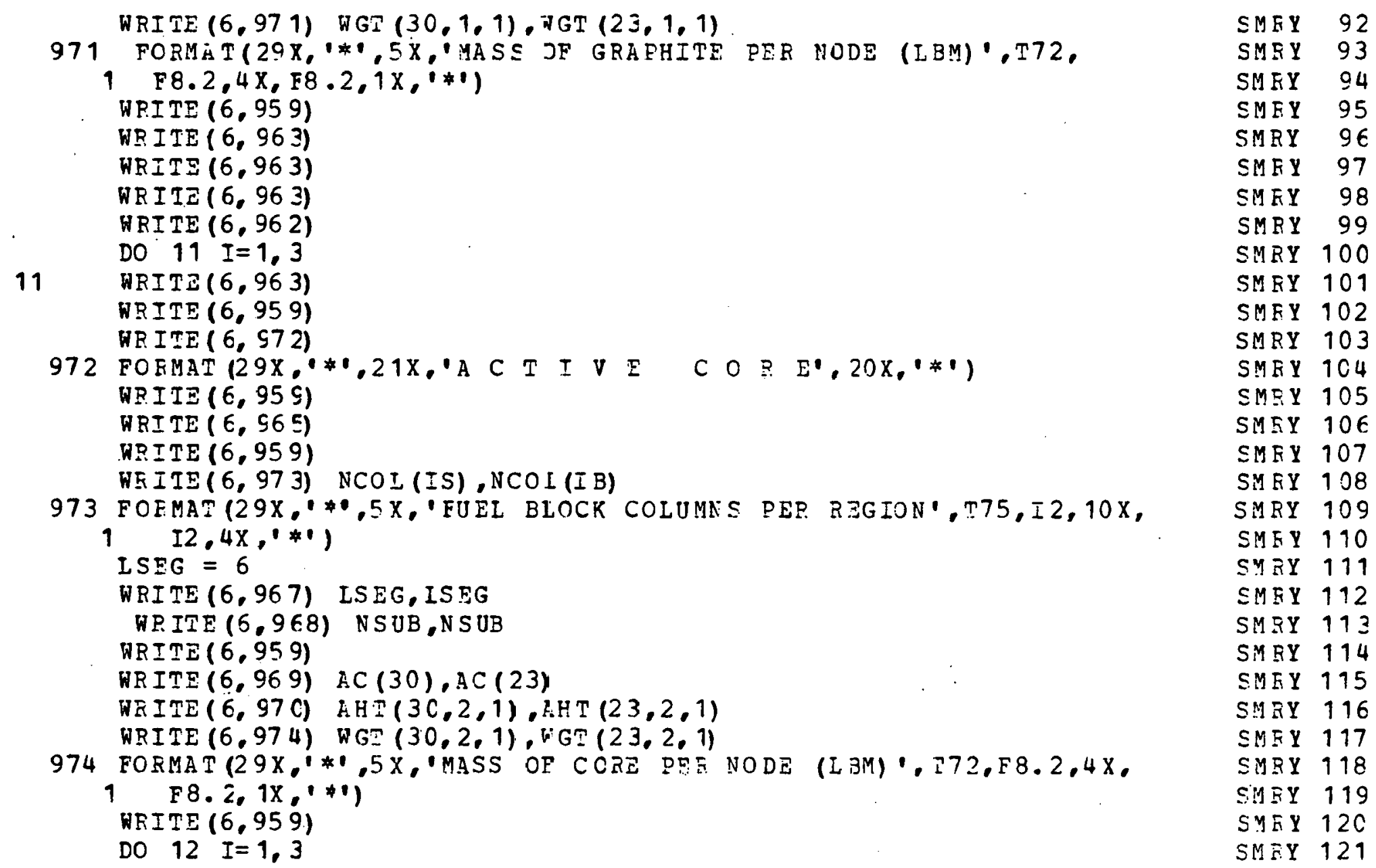


$T a b l \equiv A .2 \quad$ (cortinued)

12 WEIIE $(6,963)$

WRI IE $(6.962)$

DC $13 \quad I=1,3$

13 WRITE $(6,963)$

WFITE $(6,959)$

WRITE $(6,575)$

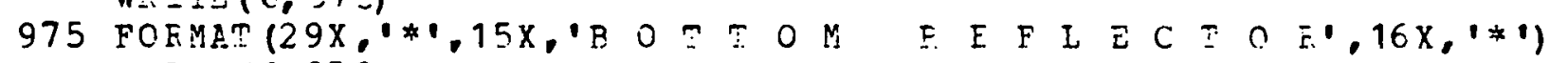

WPIIE $(6,959)$

WR $I T \Omega(6,965)$

HETE $(6.959)$

WEITE $(6,966)$ NCOL (IS), NCOI (IB)

ISEG $=1$

WP.ITE $(6,967)$ ISEG, IS $R$ G

WEIIE $(6,968)$ NSUB, NSUB

WFITE $(6,959)$

WE ¿TE $(6,969)$ HC (30), IC (23)

WKITE $(6,970)$ İ

WRT TE $(6,971)$ WG $(30,8,1)$, WGI $(23,8,1)$

W.R II $(\epsilon, 95 \subseteq)$

DO $14 \quad I=1,3$

14 WEETS $(6.963)$

WS $\sum T P(\epsilon, 962)$

WPITE $(6.963)$

WPITE $(6,976)$

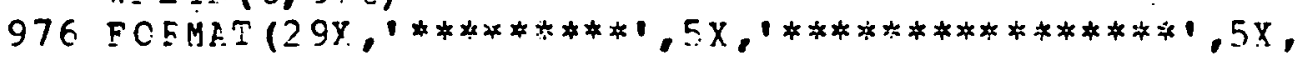

VRIII $(6,977)$

977 FOFM?

$1 \quad 1 * * * * * * * * * * * * 1,5 x, 1 * * * * * * * * * * 1)$

WRITE $(6,978)$

SMEY 122

SMEY 123

SMPY 124

SM SY 125

SMFY 126

SMEY 127

SM SY 128

SMEY 129

SMEY $1 \equiv 0$

SMRY 131

SMEY 132

SMRY 13?

SM SY 134

SMEY 135

SMEY $13 E$

SMEY 137

SMEY 138

SMEY 139

SMRY 140

SMRY 141

SM IY 142

SMRY 143

SMEY 144

SMPY 145

SMEY 146

SMEY 147

SMRY 148

SMEY 149

SMRY 150

SMRY 151 


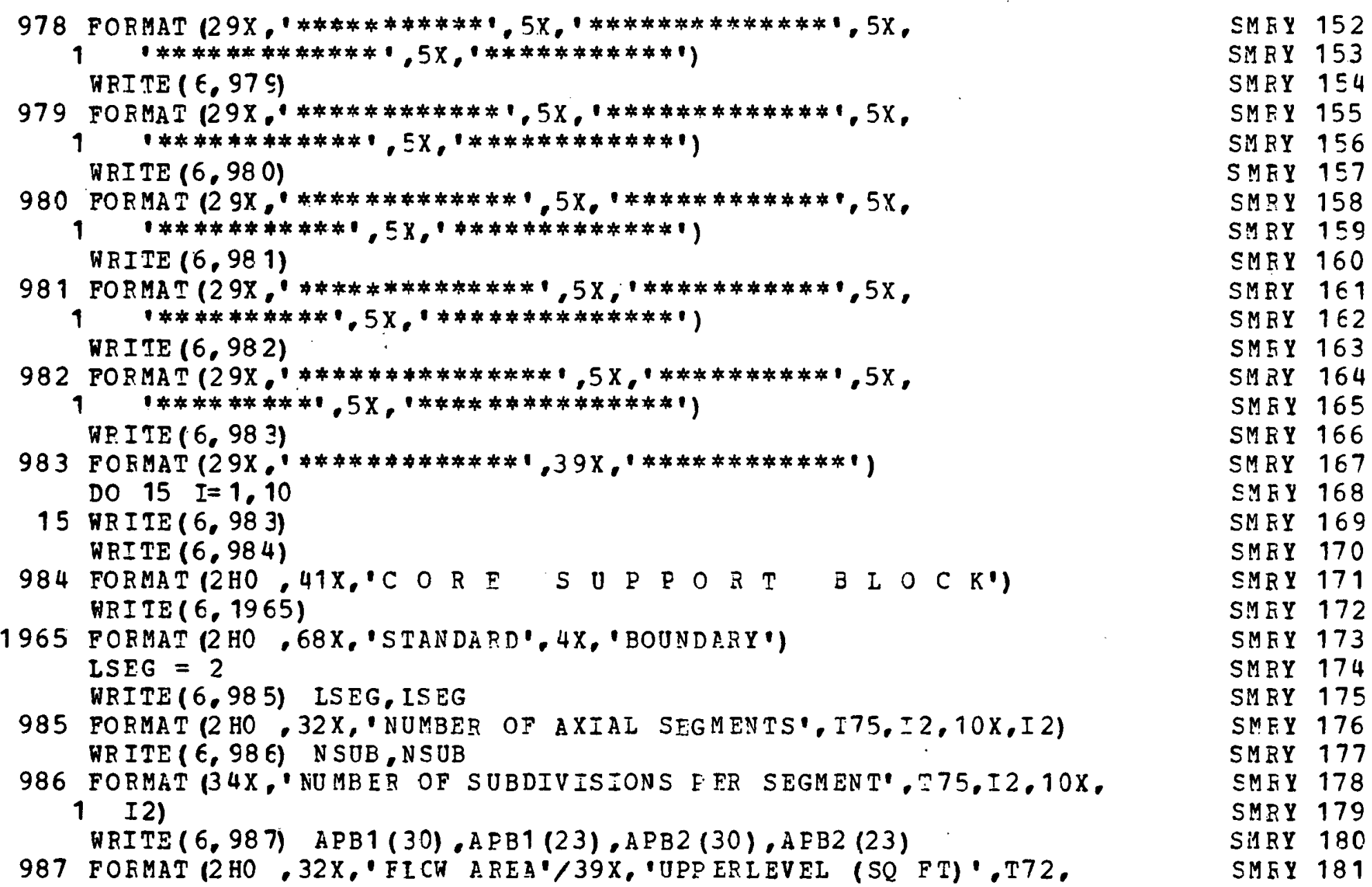


$1 F 8.4,4 X, F 8.4 / 39 X,{ }^{\prime}$ LOWEE LEVEI (SQ FE) ', I72,F8.4,4X,F8.4)

WRTTE $(6,988)$ hHi $(30,9,1), \operatorname{AHT}(23,9,1)$, A HI $(30,10,1)$, AHT $(23,10,1)$

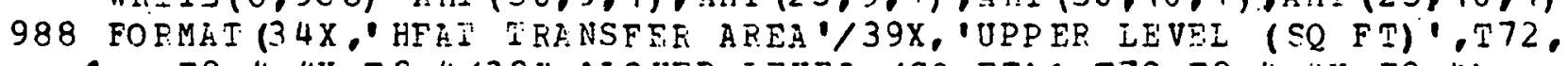

1 F8. 4, 4X,FE.4/39X, 'LOWER IZVEI (SQ FT) , , T72,F8.4,4X,F8.4)

WPITE $(6,989)$ WGT $(30,9,1)$,WGT $(23,9,1)$, WGT $(30,10,1)$, WG $(23,10,1)$

989 FOEMAT (34X, MESS OF GRAPHITZ PER NODE'/39X,

1 UPPER IEYEL (IRM) ',T72,F8.2,4X,F8,2/39X, LOW IB IEVEL (IBM) ',

$2 \div 72, F 8,2,4 X, F 8,2)$ SETURN

END

$\begin{array}{ll}\text { SMRY } & 182 \\ \text { SMRY } & 183 \\ \text { SMEY } & 184 \\ \text { SMRY } & 185 \\ \text { SMEY } & 186 \\ \text { SMRY } & 187 \\ \text { SMEY } & 188 \\ \text { SM FY } & 189 \\ \text { SMEY } & 190 \\ \text { SMEY } & 191\end{array}$

SUREOUTENE ORSPS

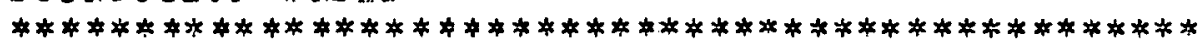

THIS SUB GOUTINE CAICULATES INITIAL OFIFICE SETIIVGS

AND THE INITIAL FIOW DISTPIBUTION

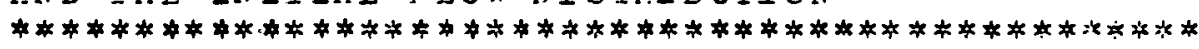

COMMON/CCFEIS/ \&KO (37), AKC (37), IKE $(37,100)$, กK:1(37) .

1 SKKE2(37), AKE? (37), DPG (37), LKT (37.100)

COMMON/OUTER TIME, WIOT, $N=(37)$, WF (37), TCOOLE $(37,101)$.

$1 \operatorname{CCOLF}(37,101), \operatorname{IFUEII}(37,10,10), \operatorname{TFUELF}(37,10,10)$,

$2 \operatorname{SSPW}(37,10,10)$

COMMON/INDUT 1/ EC (37), APT (37), ADB1(37), APB2(37), APB3(37),

1 WGT $(37,10,10)$, ВHT $(37,10,10)$

COMMON/INPUT2/ CCS, ECL, RLCF(10), AICT (10), DPL.

1 DPB 1, DPB 2, DEB 3, DPT

COMMON/INPUT 3/ NCCI(37), NREG, NSEG, NSUB, NCOLE, NSEEPS, IC!AX,

1 NSTEP

COMMON IINETTU SE, WPEP, AKOX

COMMON/INPUT 5/ KI YAX, KQMAX, KFIOW, KFRIC, KITER, KIOUE:

$\begin{array}{lr}\text { OPFS } & 1 \\ \text { ORFS } & 2 \\ \text { CEFS } & 3 \\ \text { OFES } & 4 \\ \text { OEFS } & 5 \\ \text { CEFS } & 6 \\ \text { OEFS } & 7 \\ \text { OEFS } & 8 \\ \text { OEFS } & 9 \\ \text { ORFS } & 10 \\ \text { ORFS } & 11 \\ \text { ORFS } & 12 \\ \text { CRES } & 13 \\ \text { ORFS } & 14 \\ \text { OEFS } & 15 \\ \text { CBFS } & 16 \\ \text { OEFS } & 17 \\ \text { ORFS } & 18\end{array}$


COMMON / INP OTE/ E1, E2, E3, E4, E5, E6, P7, Z8, E9

COMMON/S IG NA I/KFLAG1, KFI AG2, KFL AG3,K FL P G4,KFLAG5, KELAG6

CRFS 21

COMMON/ZNPUT 9/ PR(37), ER $(10,10)$, ERR(37)

COMMON/P AEM 2/ WOLD, TIN, IEIT, SO (37)

COMMON/PEESDE/ ODP (37), E[P(37), CDP (37), VOL $(37,10)$

OPFS 22

CEFS 23

ORFS 24

CEFS 25

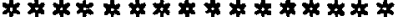

THIS SECTION CALCUIATES TEE PEESSUEE DROP ACCROSS

THE REGION WITH THE HIGHEST POWER--THE ASSUMPTION

ORFS 26

ORES 27

CFFS 28

IS MAKE THAT THE ORIFICE IS WIDE OFEN AND NO PRESSURE

ORES

CEFS

DEOE OCCORS ACCROSS THIS ORIFICE

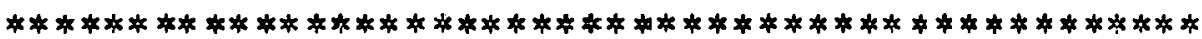

ORES

ORFS

THUS $\mathrm{TE}$ ARE AEIE TC CAICUTATE THE PIENUM TO PIENUM PRESSURE DEOE USING THIS REGION

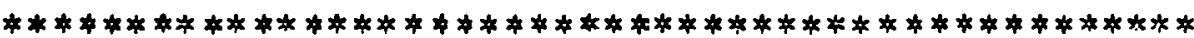

DATA CN, AKM, RK/ 2.2334E-11,0.07, 459.67/

O?.FS

OEFS

CE. S

PEAT = PSS/PDBL

CAII CCEFIS

$I=I Q M A X$

$T R=T \operatorname{COOLF}(I, 1)+3 \mathrm{~K}$

$G=W F(I) / S P$

TEKM $=(G * G * T ? * C N) /$ DSS

DE $1=T E F M * R R O X$

$\operatorname{EDP}(I)=D P 1$

$G=W F(I) / A C(I)$

TEEM $=(G * G * T F * C N) / D S S$

$D P 2=T I R M * A C(I)$

$D P P=C P 1+I P 2$

DO $200 \mathrm{~J}=1, \mathrm{~N}$ SEG

OEFS

OFES 37

CEFS 38

OX̃ES 39

CEES 40

OEFS 41

CPFS 42

CFFS 43

CEFS 44

CEFS 45

ORES 46

CEFS 47

CPFS 48 
IF (J.EC. NSEG - 1) G = NE(I)/PPE1(E)

$I F(J, E Q$. NSEG) $G=W F(I) / P Q B 2(I)$

DC $10 C K=1, N S U E$

$I=(\mathrm{J}-1) * N \subseteq U B+K$

$N C=I+1$

$T R V=(\operatorname{TCOCIF}(I, I)+m \operatorname{COOT} F(I, N O)) / 2.0$

$T F=T H V+F K$

TFEM $=(G * G * T E * C M) / E S S$

$D P Z=I E E M * A K F(I, I)$

$D E 4=T E F M * K T(I, I)$

$D E P=D E E+D F 3+D E 4$

100 CONIIN U:

IF (J.F.C. NEFG-2) GC $\cong 0175$

IF (J.EQ.NSEG-1) GO TO 180

IF (J.EC.NSEG) GO TC 190

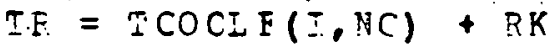

$T E F M=(G * G * T E * C N) / P S S$

DP5 = TPKM\#KM

$D F E=D P P+D E 5$

$G C \simeq 0200$

$175 T P=T C O O F(I, N C)+5 K$

TFE:M $=(G * G * T P * C N) / E S S$

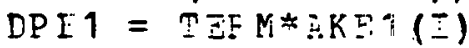

$D F F=D P E+I P E-$

GO TO 20.0

$180 T R=\mp \operatorname{COGIF}(I, N C)+3 K$

TEEM $=(G * G * T * C M) / P S S$

$D P E 2=T E P M * M E 2(I)$

$D P P=D E F+D P \equiv 2$

GO IO 200

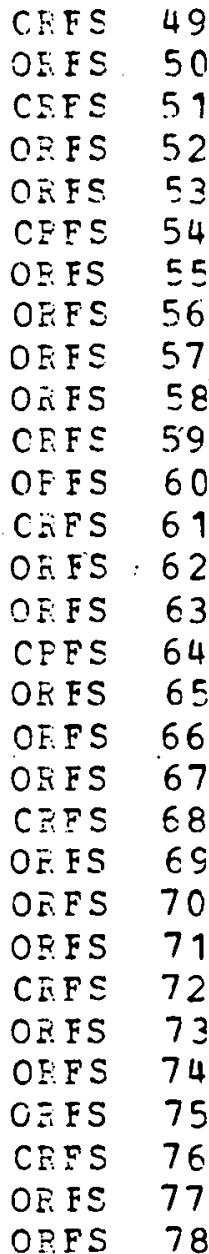




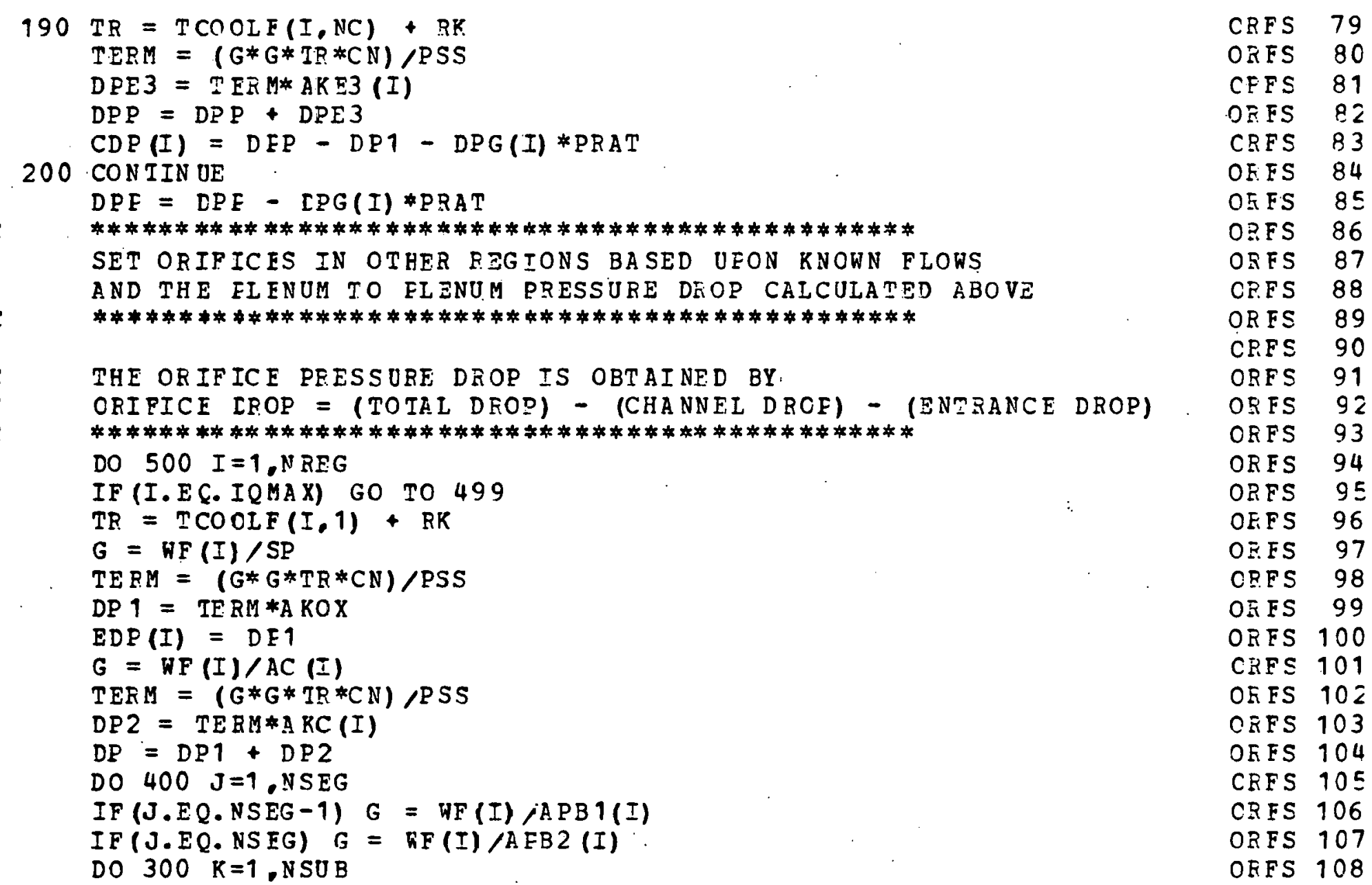


Table A.2 (continued)

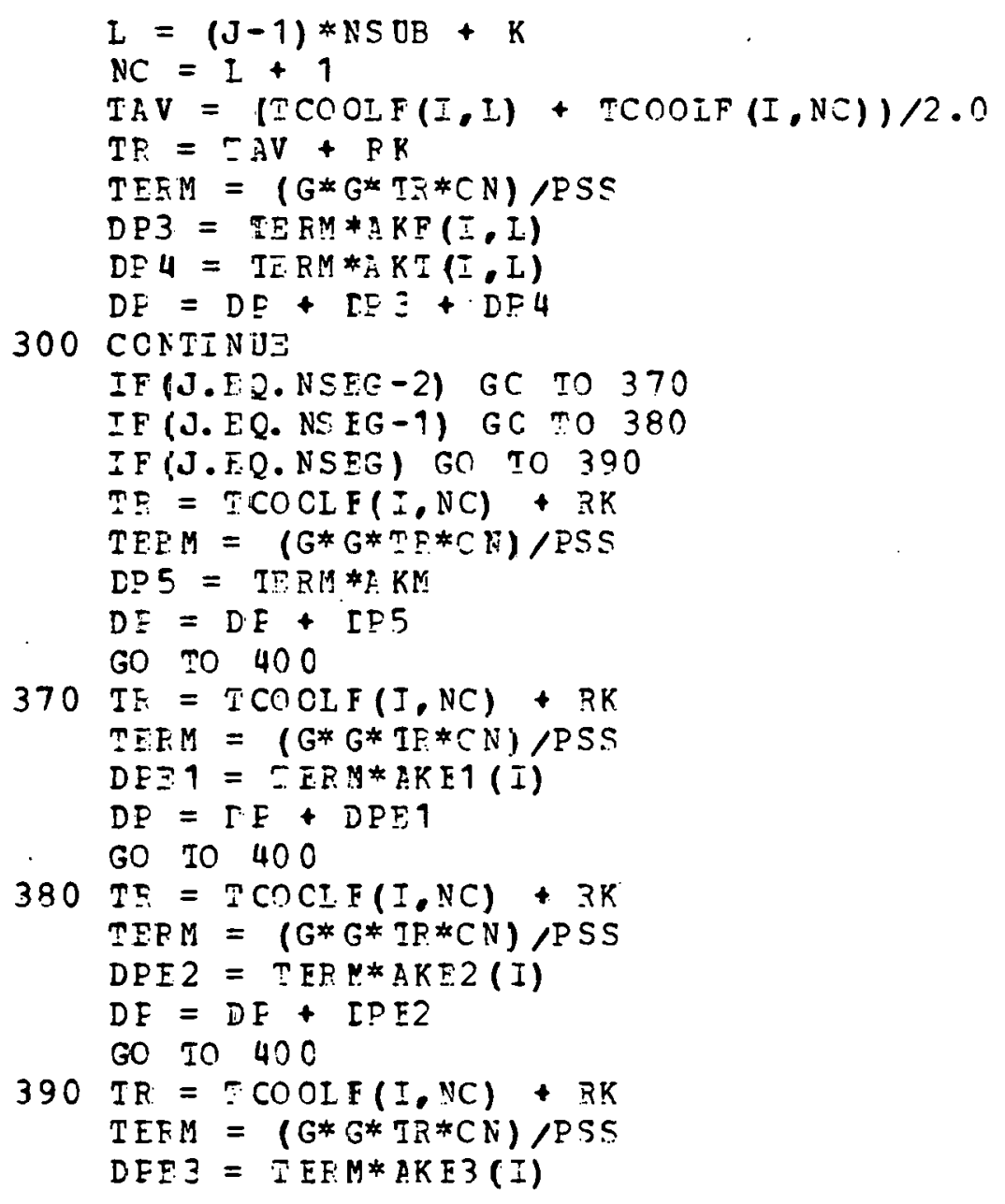

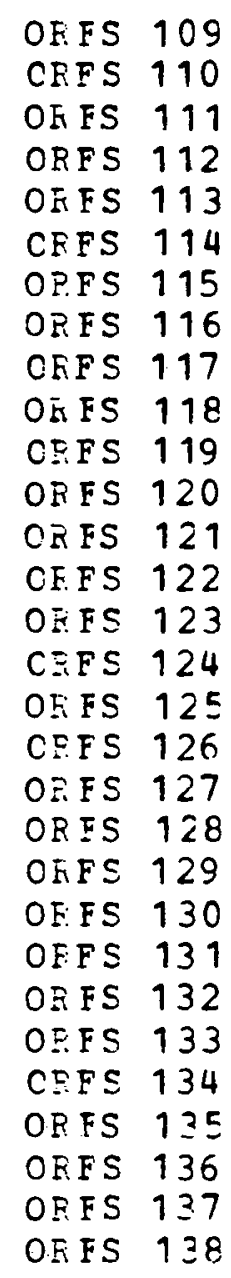




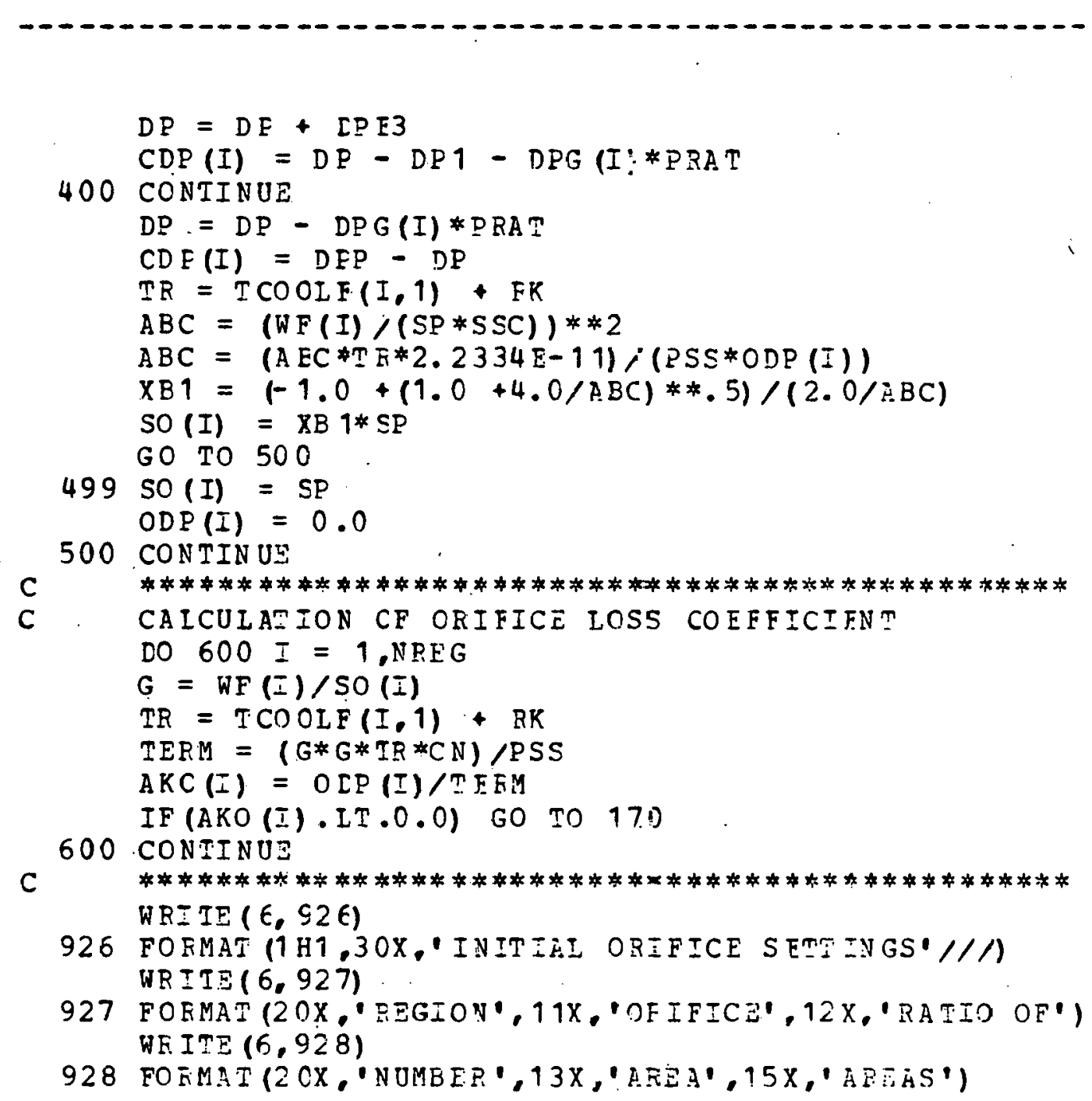

CRES 139

ORFS 140

ORFS 141

$C R E \subseteq 142$

OFFS 143

CRES 144

OEFS 145

CPFS 146

CEES 147

OEFS 148

CEFS 149

ORFS 150

OPES 151

C도S 152

OFES 153

CEFS 1.54

ORES 155

ORFS $15 E$

CAFS 157

OEFS 158

CPES 159

ORES 160

OEI 161

CEFS $1 \in 2$

O도 163

C?FS 164

OFFS 165

OEFS 166

CRFS 167

OEFS 1E8 


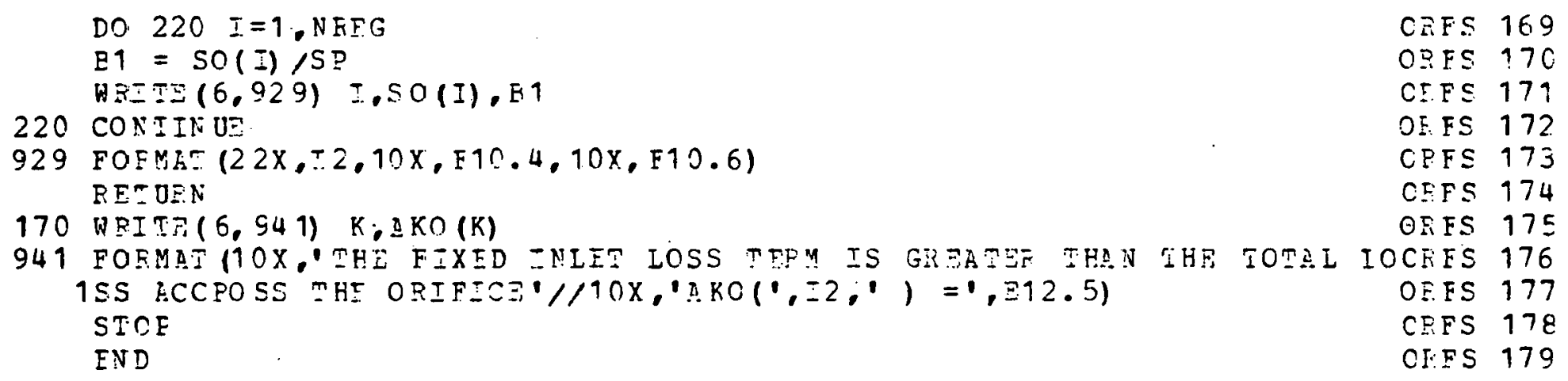

INIT

IN IT

INII

IN IT

INIT

INII

INIT

INIT

IN IT

INIT

INIT

INIS

INIT

IN IT

INII

INIT

INIT 


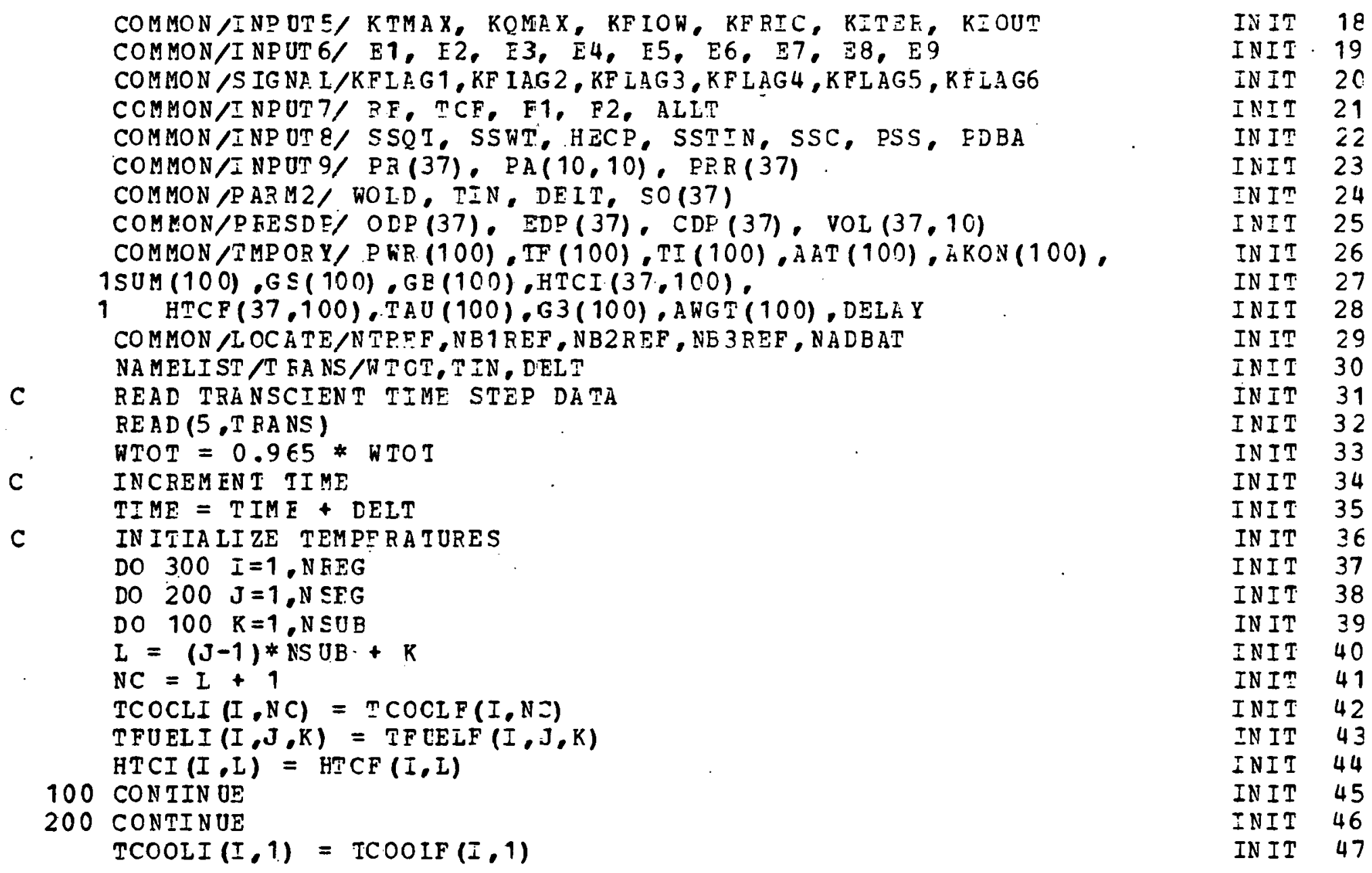


$\operatorname{TCOCLF}([., 1)=T I N$

$W I(I)=W F(I)$

300 CONTINUE

RET:URN

END

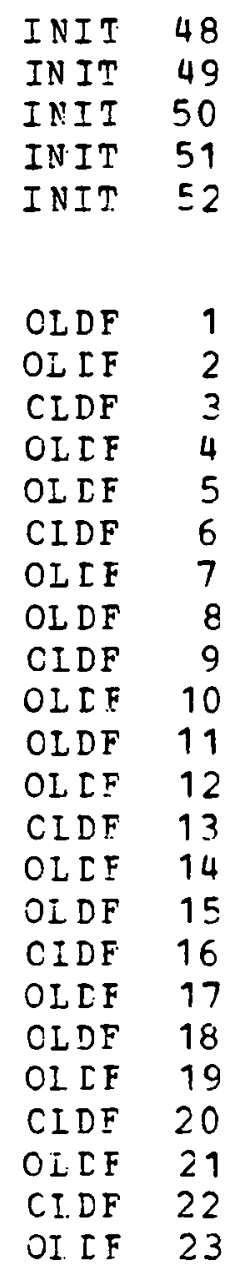

1 AKE2 (37), AKE3 (37), AKG (37), AKT (37,100)

COMMON NOUTPI / IIME. WTOT,WI (37).WF (37), ICOOLI (37, 101)

1 TCOOIF $(37,101)$, TFUEIE $(37,10,10)$, TEUEIF $(37,10,10)$,

$2 \operatorname{SSPN}(37,10,10)$

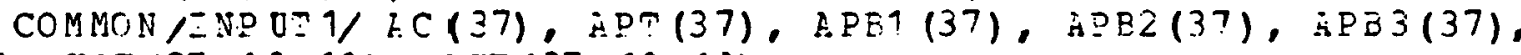

1 VGT $(37,10,10)$, EET $(37,10,10)$

COMMON / N UT 2/ DCS, DCL, ELCF(10), RICM(19), DP,

1 DEE1, DEB 2, DFB3, DPT.

COMMON/INP OT 3/ NCOI(37) . NEEG, NSEG, NSUB, NCOIT, NSTEPS, IQMAX,

1 N STEP

COMMON/SNPUS 4/ SE, WDER, AKOX

COMMON /INP ET 5/ KTMAX, KQMEX, KFIOW, KFEIC, KIAFE, KIDUT

CCMMON/INPUT6/ E1, E2, E3, E4, ت55, F.5, E7, Z8, Z9

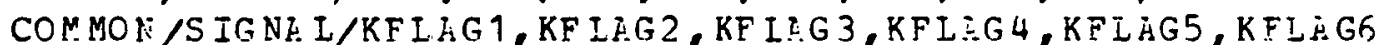

COMMON/INPU: 7/ RF, TCF, F1, F2, ALIT

COMMON IINPET8, SSQI, SSWT, HECP, SSTIN, SSC, PSS, FDEI

OI. IF 23 
COMMON/INPUT9/ PR (37), PA $(10,10), P R R(37)$

\section{SUBROUTINE SSTEMF}

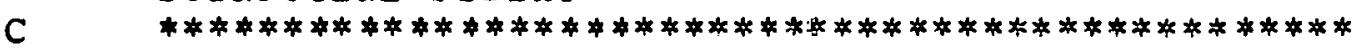

SSTF

THIS SUB FOUT INE CAICULATES IHE STELDY-STA TE TEMPERR TUEE DISTRIBUTICN IN THE COFE ASSUMMING THE AVERAGE COOIANT

SSTE

SS IP TEMEERATURE IS KNOKN

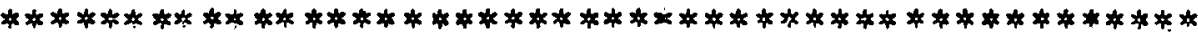

COMMON /COERIS/ \&KO (37), AKC (37), AKF $(37,100), A K E 1(37)$,

7

1 AKE2 (37), AKE3 (37), AKG (37), AKT (37,100)

SSTF 8

COMMON /OUT PT / TIME, WTOT, VI (37), WF (37). TCODLI $(37,101)$.

SSIF

$1 \operatorname{TCOOLF}(37,101), \operatorname{TFUELI}(37,10,10), \operatorname{TFUELF}(37,10,10)$,

SSIP 10

$2 \operatorname{SSPW}(37,10,10)$

COMMON/INPOT 1/ AC (37), AFT(37), A PB1 (37), AEB2(37), APP3(37)。

SSTP

1 WGT $(37,10,10), \mathrm{AHT}(37,10,10)$

CCMMON/INEUT2/ DCS, DCL, ALCF(10), ALCT(10), DD,

SSIF 12

SSIP 13

1 DEB 1, DPB 2, DPB 3, DPT

SSIF 14

COMMON/I NPUT 3/ NCOI(37), NREG, NSEG, NSUB, NCOLT, NSTEPS, IQMEX,

1 N STEP

COMMON/I NPUT 4/SP, WPER, AKOX

COMMON/INP UTE/ KTMAX, KQMEX, KFIOW, KFEIC, KITEE, KIOUT

SS TP 15

SSIE 16

SSIP 17

SSTE 18

COMMON/I NDUT6/ E1, E2, E3, E4, E5, F.6, E7, IB, E9

SSTF 19

SSIE 20 
rable A. 2 (continu $u$ )

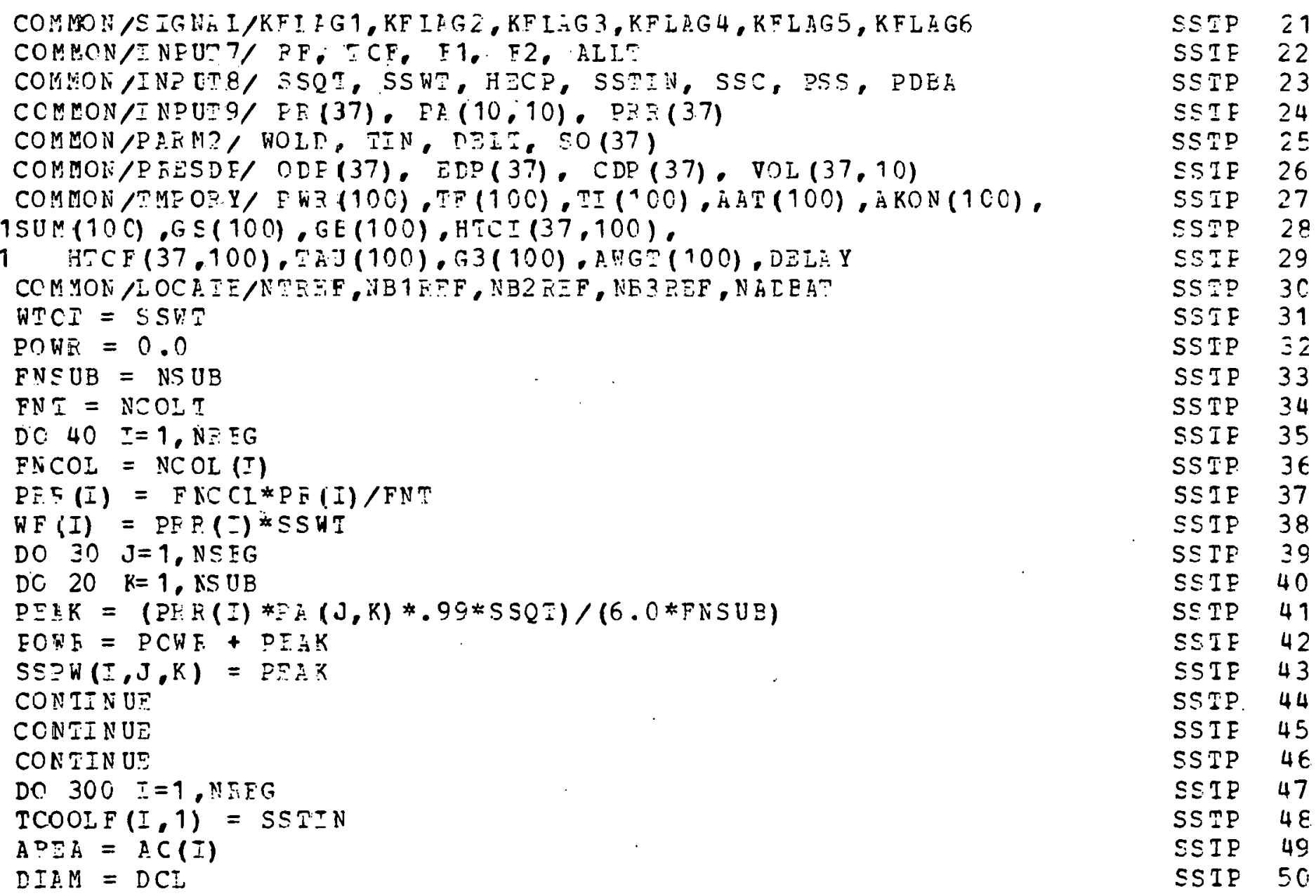


DO $200 \mathrm{~J}=1, \mathrm{~N} S \mathrm{ES}$

IF (J. E C. NS EG -1) GC I:O 45

IF (J.DQ.NSEG) GO TO 46

GO TO 47

45 AREA $=A P B 1$ (I)

$D I A M=D P B 1$

GO TO 47

46 AREA $=$ A PB $2(I)$

$D I A M=D E B 2$

47. DO $100 \mathrm{~K}=1, \mathrm{~N} S \mathrm{CUB}$

ITEE $=0$

$\mathrm{I}=(\mathrm{J}-1) * \mathrm{NSCB}+\mathrm{K}$

$\mathrm{NC}=\mathrm{I}+1$

$T \operatorname{COOLF}(I, N C)=T \operatorname{COOLF}(I, I)+\operatorname{SSPW}(I, J, K) /(W F(I) * H E C P)$

$T A V G=(\operatorname{TCOOLF}(I, I)+T \operatorname{COOLF}(I, N C)) / 2.0$

$\operatorname{TFUELF}(I, J, K)=T C C O L F(I, N C)$

$50 \operatorname{HTCF}(I, I)=$ OVEEAL (DIAM,RF,TCF, WF (I), AREA,TEUELF(I,J,K),

$1 T \operatorname{COCLF}(I, I), T$ COOLF $(I, N C), P S S, A L L T)$

$A L P H A=(H T C F(I, I) * A H T(I, J, K)) /(W F(I) * H E C P)$

ETA $=(1.0-\operatorname{EXP}(-A L P H A)) / A L E H A$

DELTMP $=\operatorname{SSPW}(I, J, K) /(\operatorname{HTCF}(I, I) * A H T(I, J, K) * E T A)$

TRES = TFUELF $(I, J, K)$

$\operatorname{TFUELF}(I, J, K)=D E I T M P+T C O O L F(I, I)$

TRES = ABS (T KES/TEUELF $(I, J, K)-1.0)$

IF (ITER.GE.KQMAX) GO TO 1000

IF (TRES. IE. E3) GO TO 100

ITER = ITER + 1

GO TO 50

100 CONTINUE

200 CON IIN UE

$\begin{array}{ll}\text { SSTP } & 51 \\ \text { SSTP } & 52 \\ \text { SSTP } & 53 \\ \text { SSTE } & 54 \\ \text { SSIP } & 55 \\ \text { SSTP } & 56 \\ \text { SSTF } & 57 \\ \text { SSTP } & 58 \\ \text { SSTP } & 59 \\ \text { SSTP } & 60 \\ \text { SSTF } & 61 \\ \text { SSTP } & 62 \\ \text { SSTP } & 63 \\ \text { SSTF } & 64 \\ \text { SSTP } & 65 \\ \text { SSTP } & 66 \\ \text { SSTP } & 67 \\ \text { SSTE } & 68 \\ \text { SSTE } & 69 \\ \text { SSTP } & 70 \\ \text { SSIE } & 71 \\ \text { SSTP } & 72 \\ \text { SSTP } & 73 \\ \text { SSTE } & 74 \\ \text { SSTP } & 75 \\ \text { SSTF } & 76 \\ \text { SSTP } & 77 \\ \text { SSTP } & 78 \\ \text { SSTP } & 79 \\ \text { SSTP } & 80\end{array}$




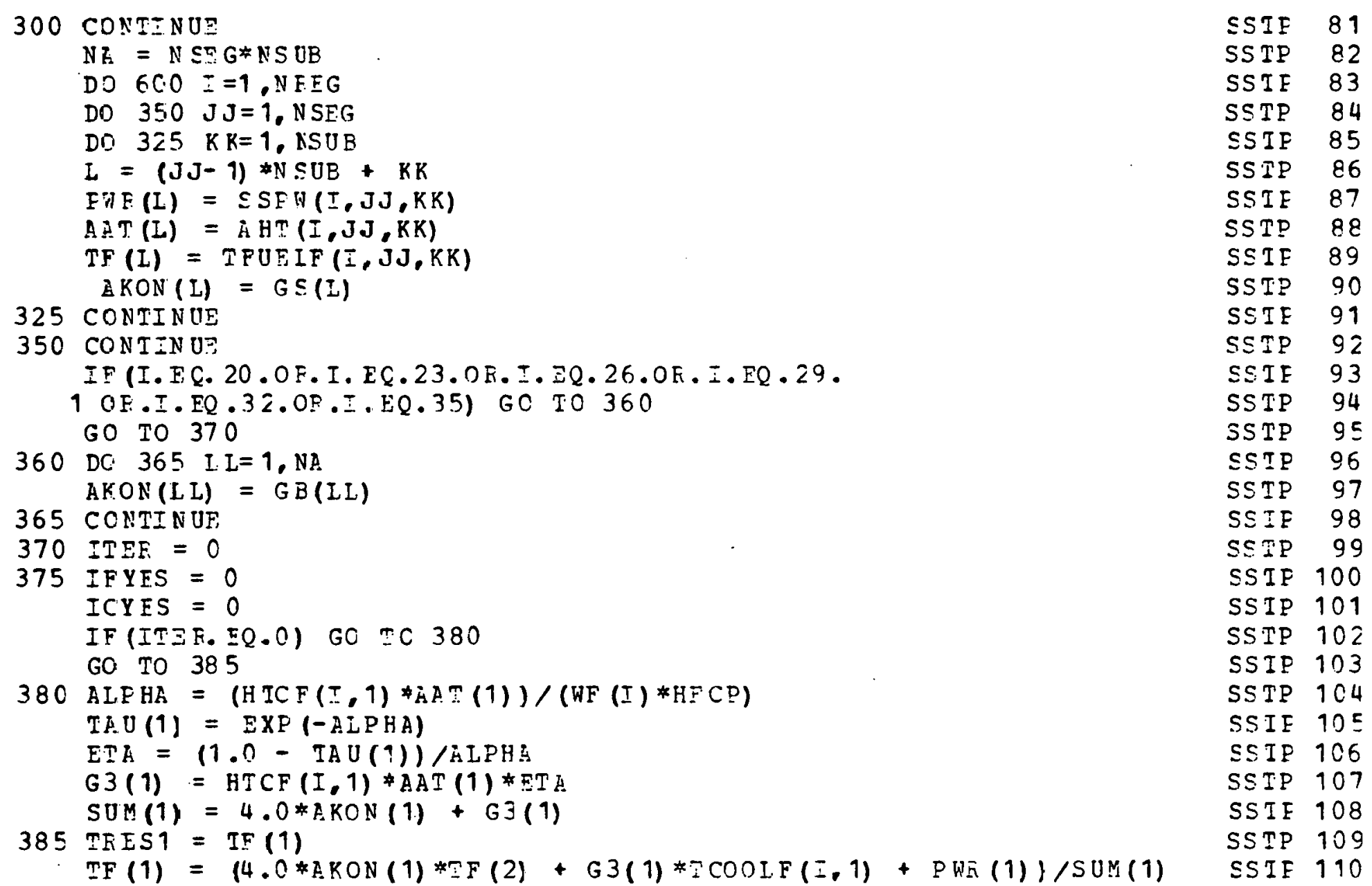




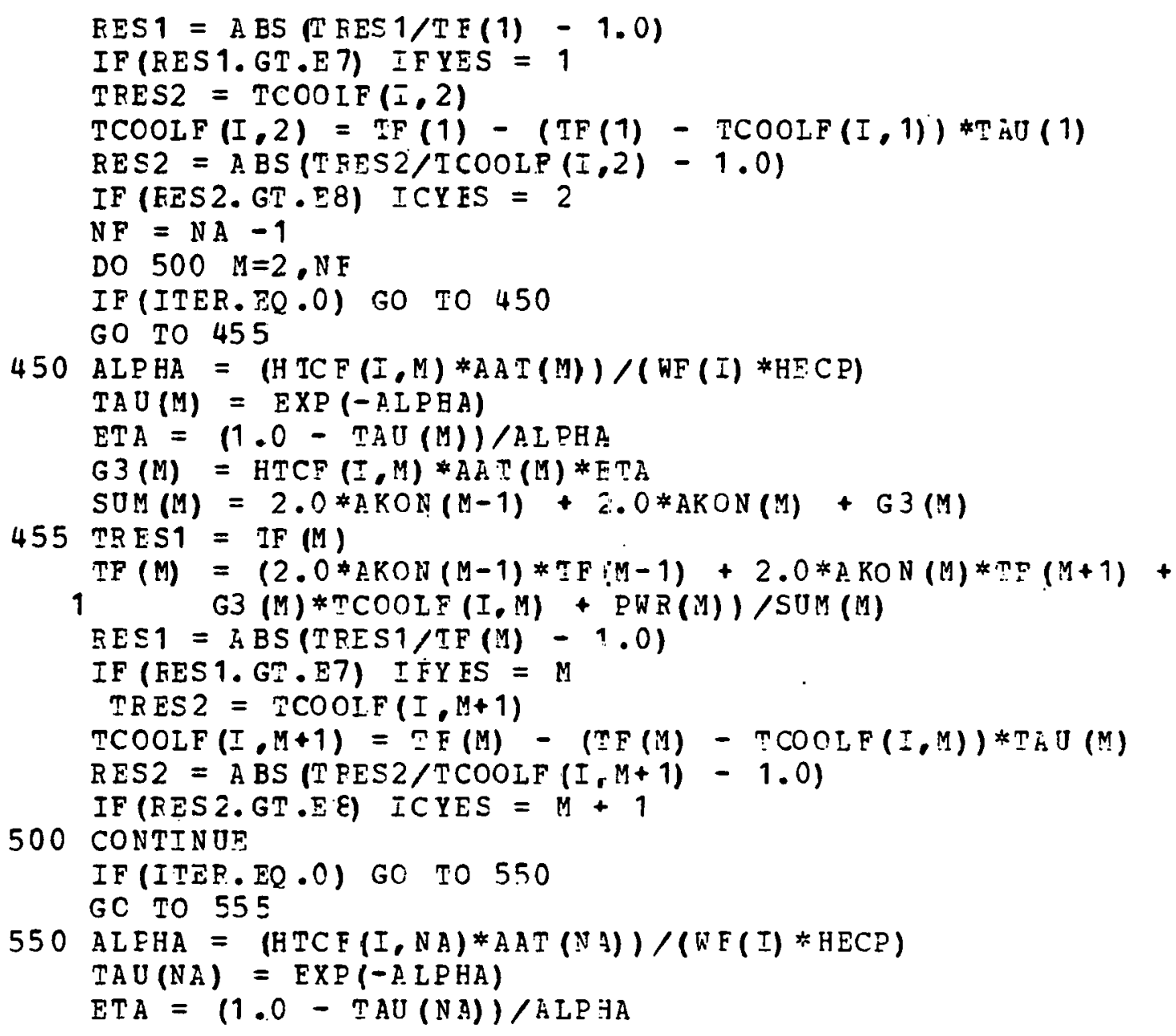


Tarle A. 2 (cortinued)

$G 3(N A)=H T C F(I, N A) * A A T(N Q) * E T A$

SSTF 141

SUM (NH) $=4 . C * K$ KCN $(N A-1)+G 3(N A)$

555 TP.ES1 $=$ TF $(N A)$

$M F(N E)=(4.0 * A K C N(N F-1) * F F(N A-1)+G 3(N A) * C O C I P(F, N E)) / S U M(N F)$

PES1 = ABS (TPPS1,TF (NA) - 1.0)

IF (EES1. GM.E7) TFYES = NA

TPES2 = TCOOLF (,$N A+1)$

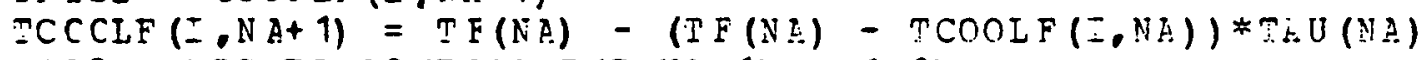

RES $2=$ A BS $(=\operatorname{RES} 2 ; \mathrm{TCOOLF}(\mathrm{I}, \mathrm{NL}+1)-1.0)$

IF (FES2.GT.FE) ZCYPS $=\mathrm{N} F+1$

$I F E F=I T E F+1$

IF (IFYES .EQ.0.AND.ICYES.ZQ.0) GO TC 575

IF (ITRP.GE.KFIAGT) GO TO 56,5

GO TO 375

565 WFITE $(6,911)$ IFYES, ICYZS, TF (IFYES), TCOOIF (I,ICY BS)

911 FOFMAT (1OX, 'CAUA ICN: MRXIMUM NUMBEF OF ITERATEONS EXCNEDED

1 10X,'STEADY STEIE TEMPTRLTUE CAICUIATION',2I5, 2F15.1)

$575 \mathrm{DO} \leq 85 \mathrm{JJ}=1$, NSEG

DO $580 \quad K K=1, N S U B$

$I=(\mathrm{JJ}-1) *_{\mathrm{N}} S U B+K K$

TFUEIF $(\Sigma, J J, K K)=T F(L)$

$58 \mathrm{C}$ CONTINUE

585 CONTINOE

600 CONTINUE

FETUR N

1000 WRITE $(6,1001)$

1001 FOEMAT 1 OX, THF ME XIMUM NUMBER OF ITEEATEONO HAS EFEN EXCEDED IN 1 SIFICE SETTIRG CRICULETION!'

STOP

END 
SUBROUTI NE TEMECR

THIS SUBROUTINE CAICUIA TES TRANSCIENT TEMEEEATURES

IN THE CORE CE IHE FORT SAINT VRAIN KEACTOR

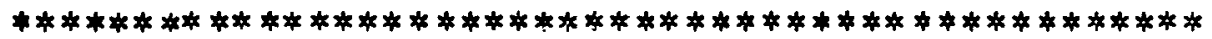

COMMON/COEFIS/ AKO (37), AKC (37), AKF (37,100), AKE1(37),

TEME

TEMP

1 AKE2 (37) $A \operatorname{AKE} 3(37)$, AKG (37) , AKT (37, 100)

TEMP

TEME

COMMON OUTPT, TIME, WTOT, WI (37), WF (37), TCOOLI $(37,101)$,

$T E M E$

TEMP 10

COMMON /I NPUT 1/ AC (37), APT (37), APB1 (37), APB2 (37), APB3 (37), TEMP 11

1 WGT $(37,10,10)$, A HT $(37,10,10)$

COMMON/INP UT2/ DCS, DCL, ALCF (10), AICT (10), DP,

TEME 12

TEMP 13

1 DPE1, DPB2, DEB3, DPT

COMMON /INP OT 3/ NCOI(37), NREG, NSEG, NSUB, NCOLT, NSTEPS, ICMAX,

1 NSTEP

COMMON /INP OT 4/ SP, WPER, AKOX

COMMON/INPUT5/ KTMAX, KQMAX, KFLOW, KFRIC, KIPER, KIOUT

COMMON/INP TT6/E1, E?, $33, E 4, E 5, E 6, E 7, E 8, E 9$

COMMON/S IG NAI/KFIAG1, KFIAG2,KFLAG3,KFLAG4,KFLAG5,KFLAG6

TEMF 14

TEMP 15

TEME 16

TEMP 17

TEME 18

TEMP 19

TEME 20

COMMON/INPUT 7\% RF, TCF, F1, F2, ALIT

COMMON /INP UT 8/ SSQT, SSWT, HECP, SSTIN, SSC, PSS, PDBA

IEME 21

CCMMON/INPUT 9/ PR (37) . PA $(10,10)$, PRR(37)

COMMON/PARM2/, WOLD, TIN, DELT, SO (37)

COMMON/P EF SDE/ ODF (37), EDP (37), CDP (37), VOI $(37,10)$

TEMP 22

TEMF 23

COMMON /TMPORY / PWR (100), TF (100), II (100), A AT (100), AKON (100),

TEMP 24

1SUM (100),GS $(100), \mathrm{GE}(100), \operatorname{HTCI}(37,100)$

$1 \operatorname{HTCF}(37,100), T A U(100)$, G3(100), AWGT $(100)$, DELAY

IEMP 25

TEMP 26

TEMP 27

TEME 28 
Table . 2 (continued)

COMMON /LOCATE/NTEEF NB1FEF, NB2REF, NB 3REF, NADBAT

TEMP 29

PFFAC = PWFRAC (IIM.E,DELT)

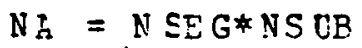

DO $600 \quad i=1$, NFFG

DO $350 \mathrm{JJ}=1, N S E G$

DO $325 \mathrm{KK}=1$, NSUE

$L=(J J-1) * N \leq I I B+K K$

FWR (I) $=\operatorname{SSPW}(I, J J, K K) * P F R A$

AAT $(L)=A H T(I, J J, K K)$

$T I(I)=T F U F I I(I, J J, K K)$

$T F(I)=T F U E I F(I, J J, K K)$

$A W G I(I)=W G I(\Sigma, J J, K K)$

$A K O N(I)=G S(I)$

325 CONIIN U?

350 CONTINUT:

IF (I.EQ.20.OR.I.EQ.23.0F.I.EQ.26.OR.I.EQ.29.

1 CR.I. EQ.32.CP.I.EQ.35) GO TO 360

GO $10 \quad 370$

360 DO $365 I I=1, N A$

$A K O N(L I)=G B(L I)$

365 CONTINUE

370 ITEF $=0$

375 IFYES $=0$

IF (ITSE. EQ.0) GC TC 380

GO TO 385

380 TAVG $=(T F(1)+T I(1)) / 2.0$

$C P=H E A T C E(T A V G, 0)$

CAPC $=(h$ WGT $(1) * C P) / D E L T$

HTC = CVESPL (DCL,RF,TCF,WF(I), AC (I), TF (1), TCOOLF (I, 1), 
$A L P H A=(H T C * A A T(1)) /(W F(I) * H E C P)$

$\operatorname{TAU}(1)=\operatorname{FXP}(-\operatorname{LIEHA})$

ETA $=(1.0-T A U(1)) / A L P H A$

$\operatorname{HTCE}(I, 1)=\operatorname{HTC} * \mathrm{ETA}$

$G 3\{1 j=H E C F(I .1) * A A T(1) / 2.0$

$\operatorname{PHR}(1)=P$ KR $(1)+2.0 * A \operatorname{KON}(1) *(\operatorname{II}(2)-\mathrm{TI}(1))-$

$1 \operatorname{HTCI}(I, 1) * A A T(1) *(T I(1)-\operatorname{TCOOLI}(I, 1)) / 2.0+\operatorname{CAEC} T I(1)$

$\operatorname{SUM}(1)=2.0 * A K O N(1)+G 3(1)+\operatorname{CAPC}$

385 TRE $\subseteq 1=$ TF (1)

$\operatorname{TF}(1)=(2.0 * \operatorname{MKON}(1) * \operatorname{TF}(2)+G 3(1) * \operatorname{TCOOIF}(\mathrm{I}, 1)+\mathrm{PWR}(1)) / \operatorname{SUM}(1)$

RES $1=$ ABS (TRES1/TF(1) - 1.0)

IF (RES 1. GT . E9) IFY ES $=1$

TRES2 = TCOOIF (I, 2)

$\operatorname{TCOOLF}(I, 2)=\operatorname{TF}(1)-(\operatorname{TF}(1)-\operatorname{TCOOIF}(I, 1)) * \operatorname{TA}[1(1)$

RES2 $=A E S(T E E S 2 / T C C O L F(I, 2)-1.0)$

IF (RES2. GT.E9) ICYES $=2$

$N F=N A-1$

DO $500 \quad M=2, N F$

IF (ITER.EQ.0) GO TO 450

GO TO 455

450 TAVG $=(T F(M)+T I(M)) / 2.1)$

IF (M. IE. NT FEF. OR.M.GE.NE1ZEF) GO TO 4.51

$C P=H E A T C P(T A . V G, 1)$

HTC = OVERAI (DCI, EF,TCF,WE(I), EC (I),TF (M), ICOOLF (I,M),

1

GO TO 454

451 CP $=$ HEATCE $(T A V G, 0)$

IF (M.G I. NB ZREF) GO TO 452

HTC = OVIEAL (DCL, EF, ICF, WF (I), AC (I), TF (M), TCOOLF (I, M)

1 $T \operatorname{COOLF}(I, M+1)$, PCBA, AIIT)

$\begin{array}{ll}\text { TEMP } & 60 \\ \text { TEME } & 61 \\ \text { TEMP } & 62 \\ \text { TEME } & 63 \\ \text { TEME } & 64 \\ \text { TEMP } & 65 \\ \text { TEME } & 66 \\ \text { TEMP } & 67 \\ \text { TEME } & 68 \\ \text { TEMP } & 69 \\ \text { TEMP } & 70 \\ \text { TEME } & 71 \\ \text { TEMP } & 72 \\ \text { IEME } & 73 \\ \text { TEME } & 74 \\ \text { TEMP } & 75 \\ \text { TEME } & 76 \\ \text { TEMP } & 77 \\ \text { TEME } & 78 \\ \text { TEMP } & 79 \\ \text { TEME } & 80 \\ \text { TEMP } & 81 \\ \text { TEME } & 82 \\ \text { TEME } & 83 \\ \text { TEMP } & 94 \\ \text { TEME } & 85 \\ \text { TEME } & 86 \\ \text { TEMF } & 87 \\ \text { TEME } & 88\end{array}$


GO TO 454

452 IF (M.GE. NB3:EF) GO $\therefore 0453$

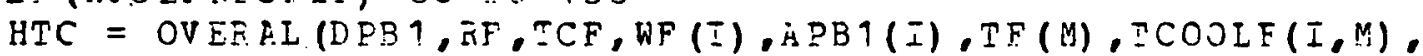

1

ICOCIF $(I, M+1), E D B A, A I I I)$

GO $T O \quad 454$

$453 \mathrm{HTC}=$ OV EERI ( PPE 2, EF, TCF, WE (E), SPB2 (I), IF (M), TCOOIF (I, M), 1 I COCIF $(I, M+1)$, FDEX, ALLT)

$454 \mathrm{CAFC}=(A W G T(M) * C P) / D E L T$

$A L E H A=(H T C * 2 . S T(M)) /(W E(I) * H E C P)$

$T A U(M)=E X P(-M I P H)$

$E T A=(1.0-T A U(M)) /$ BIEHA

$\operatorname{HTCF}(I, M)=H T C * E+$

$G 3(M)=\operatorname{HECF}(I, M) * A A T(M) / 2.0$

EWE (M) = PWE (M) + AKON $(M-1) \div(T I(M-1)-T I(M))+A K O N(B) *(T I(M+1)$

$-I I(M))-H T C I(I, M) * 2 A T(M) *(I I(M)-I C D O I I(I, M)) / 2.0$

$2+C A E C * I I(M)$

SUM $(M)=1 . K O N(M-1)+$ AKON $(M)+G 3(M)+$ CAFC

455 TKES1 = TF (M)

$M F(M)=(A K O N(M-1) * F(M-1)+B K O N(M) * I F(M+1)+$

1

$G Y(M) * \operatorname{COOLF}(I, M)+P W R(M)) / S U M(M)$

RES $1=$ i BS $(: F T S 1 /=F(M)-1.0)$

IF (FES1. G . E9) ZFYES = M

$T S E S 2=\operatorname{ICODIF}(\bar{I}, M+1)$

$\operatorname{TCOCLF}(I, M+1)=T F(M)-(T F(M)-T \operatorname{COCL}(I, M)) \neq T H U(M)$

RES2 = SBS ITRES2/ICOOLF (I., M) - 1.0)

IF (FES 2.G . . S) TCYFS $=M+1$

500 CONTINUE

IF (ITER.EQ.O) GO TO 550

GO TO 555

550 TEVG $=(T F(N A)+T I(N E)) / 2.0$

TEYP 89

TTME 90

TEMP 91

TEMP 92

TEME 93

TEMF 94

TEME 95

TEMF 96

IลME 97

TEME 98

TEMP 99

TEME 100

TEMP 101

TEME 102

TEN.F 103

TEMF 104

IEMF 105

TEMP 106

IEME 107

TEMP 108

TEMP 109

TE KE 110

TFMP 111

IEME 112

TEME 113

TEMP 114

TE.MF 115

TEMP 116

TEME 117

IEME 118 


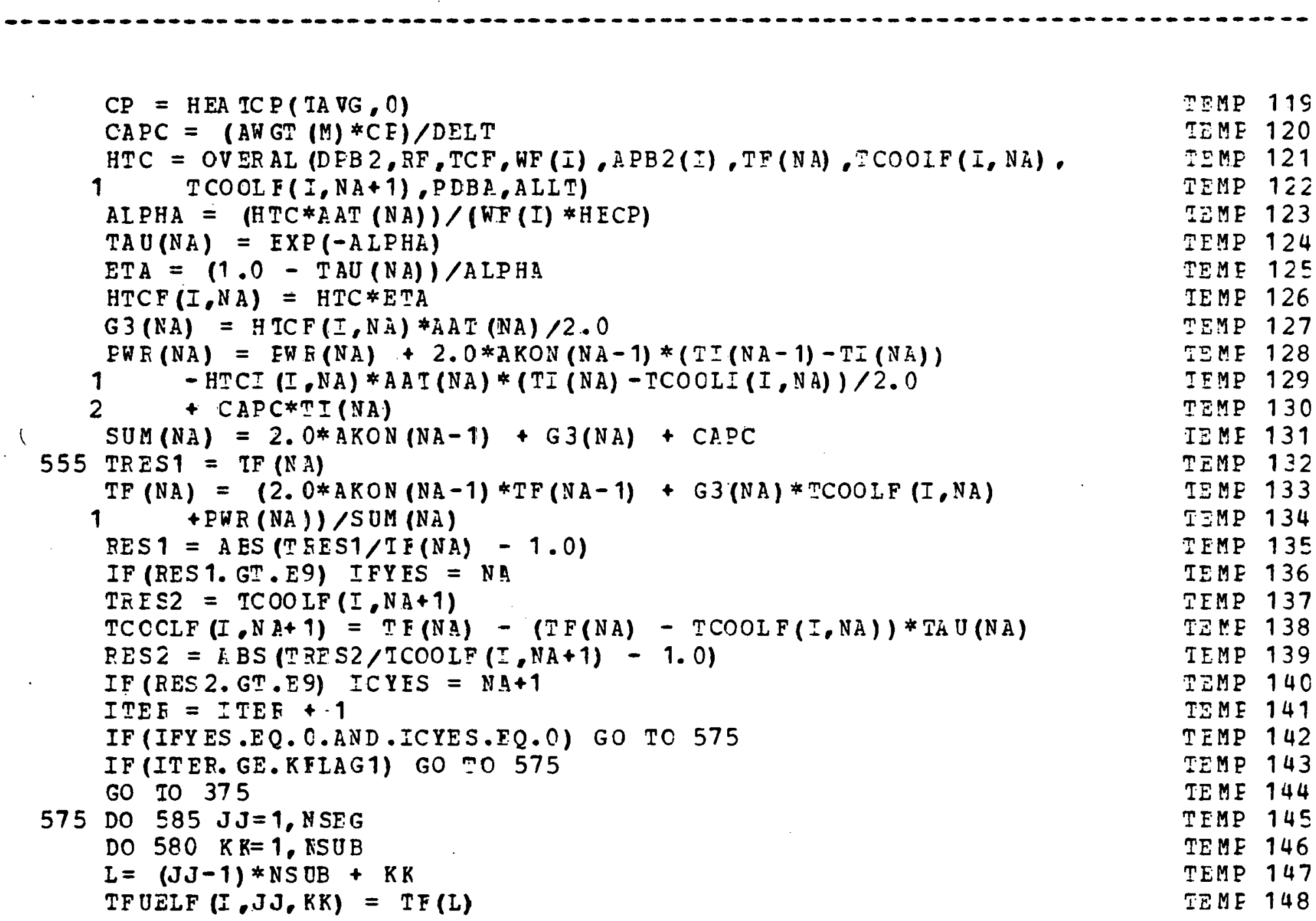

TEMP 119

TEME 120

TEM 121

TEMP 122

TEME 123

TEMP 124

TEME 125

TEME 126

TEMP 127

IEMF 128

IEMP 129

TEMP 130

IEME 131

TEMP 132

TEME 133

I $\equiv M P \quad 134$

TEMP 135

TEME 136

TEMP 137

TENE 138

TEMP 139

TEMP 140

TEME 141

TEMP 142

TEMP 143

TE ME 144

TEMP 145

TEME 146

TEMP 147

TEME 148 
580 CONIIN UE

585 CONTENUE

600 CONIINUF

FETUR

END

$\begin{array}{ll}\text { TEMP } & 149 \\ \text { TEMF } & 150 \\ \text { TEMF } & 151 \\ \text { TEMP } & 152 \\ \text { TEME } & 153\end{array}$

SUBROUTTNE COEFIS

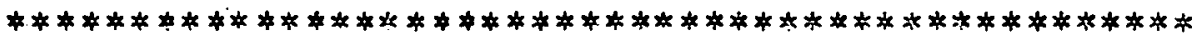

SUBFOUTINE CCFFIS CILCUIREES LOSS COEFFICIENTS GIVEN

COFS

COFS

CCFS

TEMPEEATUR FS AND FICWS

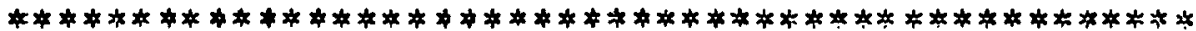

COMMON/CCEFIS/AKO (37), AKC(37), AKF (37,10C), AKE1(37) .

COFS

COFS

1 IKE2(37), IKE3(37), AKG (37), FK: $=(37,100)$

COMMON/OUEPT / TIME, WTOF, WE(37), WF(37), ICOOLE (37.101).

CCFS

COFS

COFS

COFS

TCOOLF $(37,101), \operatorname{IFUFL} 2(37,10,10), \operatorname{TFUELF}(37,10,10)$,

$2 \operatorname{SSPW}(37,10,10)$

COMMOK/INFUT 1/ AC (37), RPT (37), ADB1 (37), APB2(37), \&FB 3 (37) ,

COFS

COFS

COES

COFS

COMMON /I NPUT2/ CCS, DCI, AICP(10), AICT (10), DE,

$1 \mathrm{DB} 1, \mathrm{DB} 2, \mathrm{DB} 3, \mathrm{DP}$ ?

COMMON/INEUT 3/ NCCI (37), NPEG, NSEG, NSUE, NCOLE, NSTLPS, IQMAX,

1 NSTEP

COMMON/INFOT 4/SE, WEER, AKOX

COMMON/INPUM 5/ KIMAX, KQMEX, KFIOW, KFEIC, KIMSE, KIOUT

COMMOH/ENF CT6/ $: 1, F 2, F 3, \Xi 4, \Sigma 5, \pm 6, \mathrm{E7}, 58, \mathrm{E9}$

CCMMON/S IGNAI/KPI A G , KFIAG2, KFLAG 3, K FLEG4,KFLAG5,KFiAG6

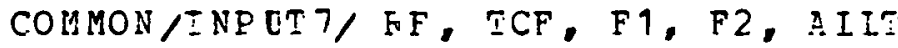

COMMON/ENFOT 8/ SSQI, SSMM, HFCD, SSTIN, SSC, PSS, PDBE

COMMON/ZNDOT9/ ER (ミ7), FE $(+0,10)$, EEI $(37)$
COFS 14

COFS 15

CCFS 16

COFS 17

COFS 18

COFS 19

COFS 20

COFS 21

COFS 22

COES 23 
COMMON/PARM2/ WOLL, TIM, DELT, SO (37)

COMMON/PRESDP/ ODP (37), $\operatorname{EDP}(37), \operatorname{CDF}(37), \operatorname{VOL}(37,10)$

COFS

COFS

COFS

DO $300 \quad I=1, N$ REG

$D P G=0.0$

RENC $=$ RENUM (WF (I),AC (I), TCOOIF $(I, 1), D C L, 1,0,1)$

$A K C(I)=C O N T R C(R E N O, A C(I), A P T(I))$

$\mathrm{NC}=(\mathrm{NSEG}-2) * \mathrm{NSUB}+1$

RENO = REN UM (WF (I), AC (I), TCOOLF (I, NC),DCI, 1.0,1)

$\operatorname{AKE} 1(I)=\operatorname{EXEANS}(E F N O, A C(I), A P B 1(I))$

$N C=(N S E G-1) * N S \cdot U B+1$

RENO = REN OM (WF (I),APB 1 (I), TCOOIF (I,NC),DE1,1,0,1)

$A K E 2(I)=$ EXEANS (RENO, APB $1(I), A P B 2(I)$ )

$N C=N S E G * N S O B+1$

RENO = REN UM (WF (I), APB2 (I), TCOOIF (I,NC),DE2,1.0,1)

$\operatorname{AKE} 3(I)=$ EXEANS (RENO, APB2(I),APB3(I))

$A R E A=A C(I)$

$D I A M=D C L$

LO $200 \cdot J=1, N$ SEG

IF (J.EC. NS EG-1) GO TO 40

IF (J.EQ. NSEG) GO TC 45

GO TO 50

40 AREA $=A E B 1$ (I)

$D I A M=D . B 1$

GO TO 50

45 AREA $=A P B 2(I)$

$D I A M=D E 2$

50 DO $100 \quad K=1, N \leq O B$

$I=(J-1) * N S D B+K$

$N C=I+1$

COFS 27

COFS 28

CCFS 29

COFS 30

COFS 31

COFS 32

COFS 33

COFS 34

COFS 35

COFS 36

COFS 37

COFS 38

COFS 39

COFS 40

COES 41

COFS 42

COFS 43

COFS 44

COFS 45

COFS 46

COFS 47

COFS 48

COFS 49

COES 50

COFS 51

COFS 52

COFS 53 
Table A.2 (continued)

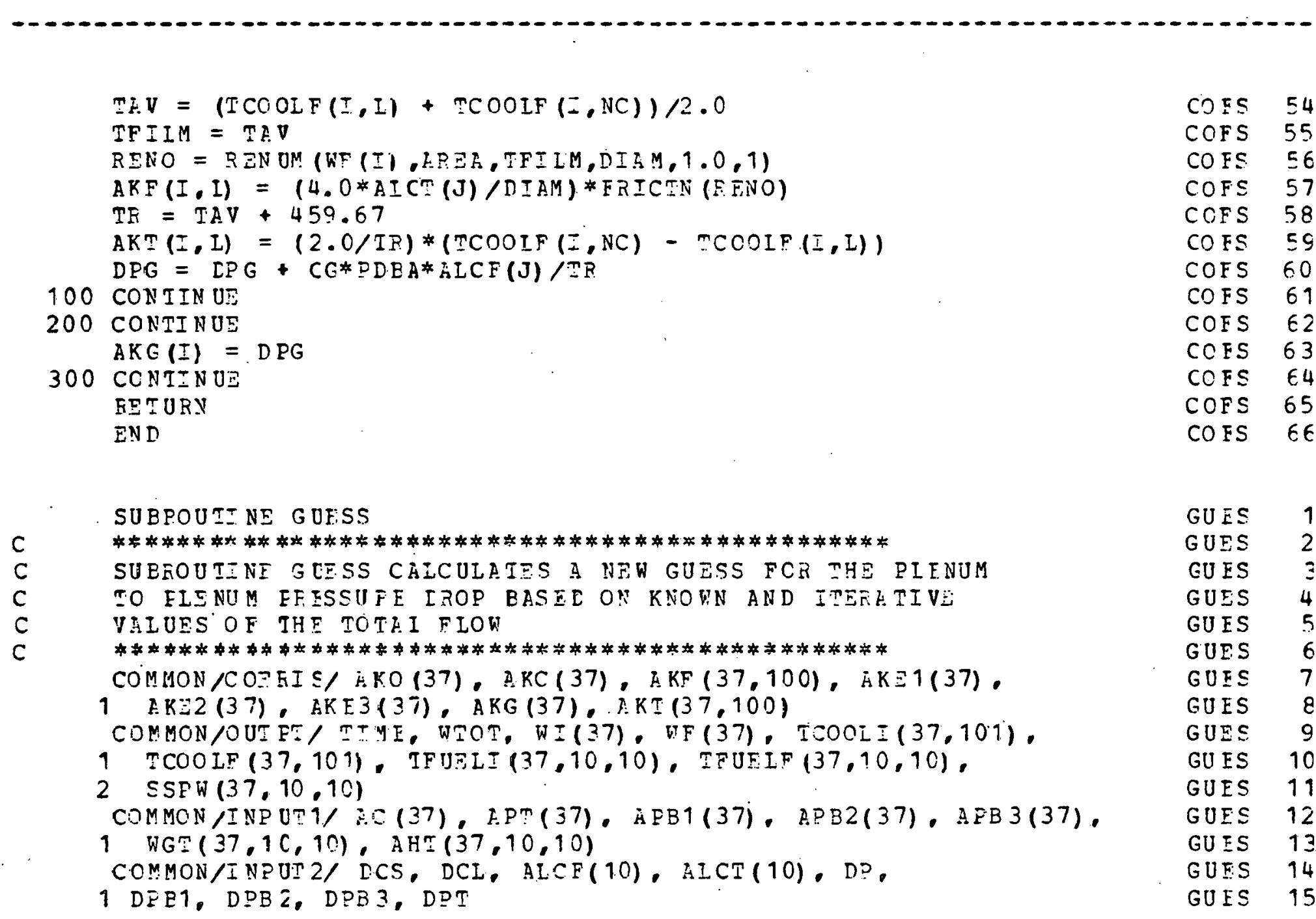


COMMON/I NPUT 3/ NCCI (37). NREG, NSEG, NSUB, NCOLT, NSTEFS, IQMAX, GUES 16 1 N STEP

COMMON/INPUT 4/ SP, WPER, AKOX

COMMON /INP OTS/ KTMAX, KQMAX, KFIOW, KFRIC, KIMER, KIOUT

COMMON/INPUT 6/ E1, E2, E3, E4, E5, E6, E7, E8, E9

COMMON/S IG NA I/KFIAG 1, KF IAG 2, KF IAG3, KFLAG4,KFIAG5, KFLAG6

COMMON/INPOT7/RF, TCF, F1, F2, ALIT

COMMON/INP OTE, SSQT, SSWT, HECP, SSTIN, SSC, PSS, FDBA

COMMON/I NP OT 9/ PR (37) . FA $(10,10)$, PRR (37)

COMMON $P$ PARM2, WOID, TIN, DEIT, SC(37)

COMMON/PFESDF/ ODF (37), EDP (37), CDP (37), VOL $(37,10)$

DATA DD.AA .XMU/0.05208, 54.0.0.1\%

RENO = DD* KTOT/(XUU*AA)

IP (EENC.IT.2100.0) GO TO 100

$D P=D P *(W T O T / W O I D) * 1.68$

RETURN

$100 \mathrm{DP}=\mathrm{DF}$ (WTOT/WOLL)

RETURN

END

GUES 17

GUES 18

GUES 19

GUES 20

GUES 21

GUES 22

GUES 23

GUES 24

GUES 25

GUES 26

GUES 27

GUES 28

GUES 29

GUES 30

GUES 31

GUES 32

GUES 33

GUES 34

\section{SUBEOUTI NE REFIOW}

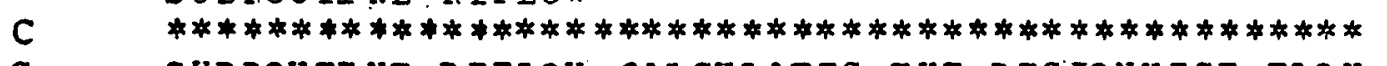

C SUBFOUTINE REFIOW CALCULATES THE REGIONWISE FLOW DISTRIBUTION

REFI

REFI AT THE NEW TIME LEVEL GIVEN SEMPERATURES AND LOSS COEFFICIENTS

REFI

REFI ***********************************************1

REFI

COMMON/COERIS/AKC (37), AKC (37), AKF (37, 100), AKE1(37),

REFI

$1 \operatorname{AKE} 2(37), \operatorname{AK} \equiv 3(37), \operatorname{DPG}(37), \operatorname{AKT}(37,100)$

COMMON /OUTET/ TIME, WTOT, WI (37) , WF (37) , TCOOII $(37,101)$.

$1 \operatorname{TCOOLF}(37,101)$, TFUfiI $(37,10,10), \operatorname{TFUELF}(37,10,10)$, 
$2 \operatorname{SSP}(37,10,10)$

COMYON/ENDT 1/AC (37), APT (37), ADB1(37), APB2(37), APB 3 (37)

1 W

COMMON/ENDUI 2/ DCS, DCL, AICF(10), AICT. $(10), D P$,

REFI 12

REFI 13

1 DPB1, DPB 2, DPB $3, D P T$

REFI 14

COMMON/INPUT 3/ NCOI (37), NEEG, NSEG, NSUB, NCOLI, NSTEPS, IOMAX, EEFI 15

1 N STEP

COMMON/INPUT 4/SP, WPEE, AKOX

COMMON / INP OTS, KTMAX, KQMAX, KFIOW, KFRIC, KITZR, KIOJI

COMMON/ENPUT 6/ E1, E2, E3, Е4, E5, E6, E7, Z6, 89

COMMON/S IGNE I/KFIhG1,KF LAG 2, KFI IGG 3,KFILG4,KFLAG5,KFLAG 6

COMMON IINP UT T/ RF, TCF, F1, F2, AIIT

COMMON/I NPU: 8/ SSCT, SSWT, HECP, SSTIN, SSC, PSS, PDEA

COMMON IINP UT 9/ PP (37). FA $(10,10)$, PFE (37)

COM YON/PAEM2/ WOLT, TIN, DELI, SO(37)

COMMON /F RE: SNP/ ODE (37), ENP (37), CDE (37), VOI $(37,10)$

DATA CN, EKM, DK/ 2.23345-11,0.001, 459.67/

DO $300=1$, N REG

$T E=T C O O I F(I, 1)+F K$

TEEM1 $=((T D * C N) /(E L B A * S O(I) * S O(I))) * A K O(I)$

IEEM $2=((I R * C N) /(P D B A * S F * S P)) * A K O X$

TEFM $3=((T E * C N) /(E I B A * A C(I) * A C(I))) * A K C(I)$

TERM = TFF.M + TESM2+TERM 3

AF. $E A=L C(I)$

DO $200 \quad J=1$, NSEG

IF (J.FQ.NSBG-1) GO TO 40

IF (J. I. . NSEG) GO $\cong \mathrm{C} 45$

GO TO 50

$40 \mathrm{AREB}=\angle \mathrm{PB} 1(\mathrm{I})$

GO TO 50

REFI 16

FEFI 17

FEFI 18

REFI 19

PEFI 20

EEFI 21

FミFI 22

REFI 23

PEFI 24

PEFI 25

FEFI. 26

SEFI 27

FEFI 28

RIEI 29

SEFI 30

FEFI $\equiv 1$

KEFI 32

FEFI 33

FEFI 34

REFI 35

REFI 36

TEFI 37

FEFI 38

EEFI 39 
Table A.2 (continued)

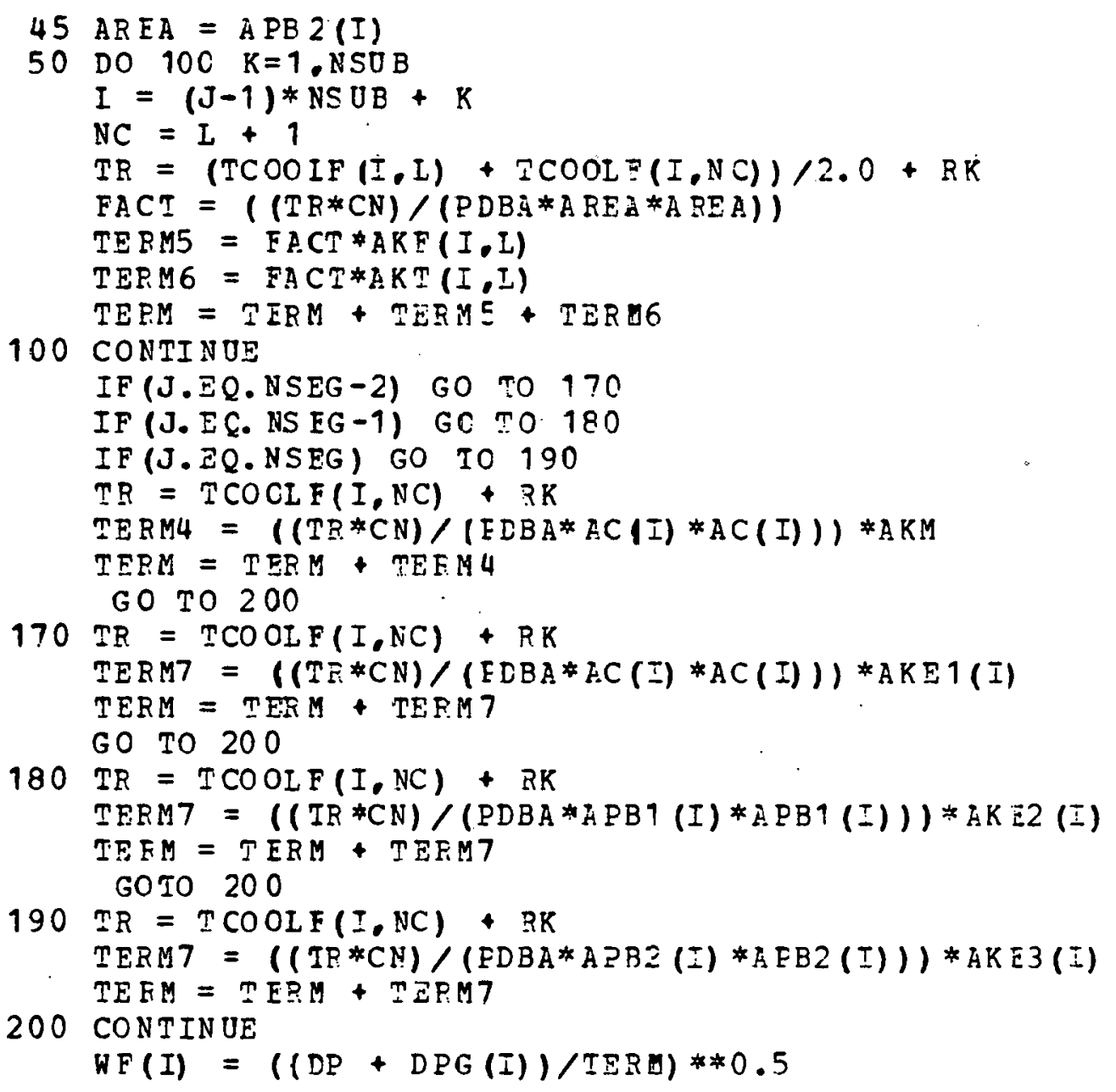

\begin{tabular}{|c|c|}
\hline $\begin{array}{l}\text { REFI } \\
\text { REFI } \\
\text { REFI } \\
\text { REFI } \\
\text { PEFI }\end{array}$ & \\
\hline EEFL & \\
\hline E F I & \\
\hline$E F I$ & \\
\hline KEFL & \\
\hline RE FI & \\
\hline$R \bar{E} \mathrm{FI}$ & \\
\hline$E E I$ & \\
\hline EEFI & \\
\hline QEEL & \\
\hline REFI & \\
\hline EEFI & \\
\hline PEFI & \\
\hline$F E F$ & \\
\hline REF I & \\
\hline$\therefore I F L$ & \\
\hline EEF L & \\
\hline PEFI & \\
\hline REFI & \\
\hline PEFI & \\
\hline$\tilde{S} \Sigma F L$ & \\
\hline$E E F I$ & \\
\hline GEFI & \\
\hline REF I & \\
\hline EFI & \\
\hline BEI & \\
\hline
\end{tabular}


$O D F(I)=Z E R N 1 * W F(I) * W F(I)$

$\operatorname{EDP}(I)=T E R M 2 * W F(I) * W F(I)$

TEEMC = TUSM - TESM1 - TERM2

300 CONITN UE

$\operatorname{CDF}(I)=\operatorname{TER} \mathrm{MC} * \mathrm{WF}(I) * N F(I)-\operatorname{LPG}(\mathrm{I})$

RETURN

END

$\begin{array}{lr}\text { FEFI } & 70 \\ \text { REFI } & 71 \\ \text { EEFI } & 72 \\ \text { FEFI } & 73 \\ \text { EEFI } & 74 \\ \text { PEFI } & 75 \\ \text { NEFI } & 76 \\ & \\ \text { NOFL } & 1 \\ \text { NOFI } & 2 \\ \text { NOFI } & 3 \\ \text { NOFI } & 4 \\ \text { NOFI } & 5 \\ \text { NOFI } & 6 \\ \text { NOFI } & 7 \\ \text { NOFI } & 8 \\ \text { NOFI } & 9 \\ \text { NOFI } & 10 \\ \text { NOFI } & 11 \\ \text { NOFL } & 12 \\ \text { NOFI } & 13 \\ \text { NOFI } & 14 \\ \text { NOFI } & 15 \\ \text { NOFI } & 16 \\ \text { NOFI } & 17 \\ \text { NOFI } & 18 \\ \text { NOFI } & 19 \\ \text { NOFI } & 20 \\ \text { NOFI } & 21\end{array}$


COMMON/INP OM6/ $21, E 2, F 3, \pm 4, E 5,56, \pm 7, \pm 8, \Xi 9$

CCMMON/S IG NAI/KFIAG1, KFIAG2,KFLAG3,K FIAG4,KFLAG5,KFIAG 6

COMMON/INPET7/RF, TCF, F1, F2, ALIT

COMMON/I NDUT 8/ SSQT, SSWI, HECP, SSTIN, SSC, PSS, FDBA

COMMON/INP OT 9\% PF (37), PZ $(10,10)$, ERE (37)

COMMON/PAR 2 / WOLE, TIN, BEIT, SO (37)

COMMON /P RESDP/ ODP (37), EDP (37) , $\operatorname{CDP}(37) \cdot \operatorname{VOL}(37,10)$

COMMON /TMPORY/ PWR (100), TF (100), II (100), A AT (100), AKON (100), 1SUM (100),GS (100), GE (100), HTCI $(37,100)$,

1 HTCE $(37,100)$, TL O (100),G3(100), AG T $(100)$, DELAY

COMMCN/L CCATE/NTREF,NB1REF, NB2REF, NB 3R TF, NADBA T

PFRAC = PWPK AC (TIME,DELT)

$N A=N S E G * N S U B$

DO $600 \quad I=1$, N FEG

DO $350 \quad \mathrm{~J}=1, \mathrm{~N}$ SEG

DO $325 \mathrm{KK}=1$, NSOB

$I=(J J-1) * N S U B+K K$

FWF (I) $=\operatorname{SSPW}(I, J J, K K) * P F R A C$

$A A T(I)=A H T(I, J J, K K)$

$T F(I)=T F U E I F(I, J J, K K)$

$T I(I)=T F U E I I(I, J J, K K)$

$A W G T(I)=W G I(I, J J, K K)$

$\operatorname{AKCN}(L)=G S(I)$

325 CON TIN UE

350 CONTINUE

IF (I.EQ.20.OR.I.EQ.23.OR.I.EQ.26.OF.I.EQ.29.

1 OR.I.EQ.32.OR.I.EQ.35) GC TO 360. GO TO 370

360 DO $365 I I=1$, NA

$A K O N(I I)=G E(I I)$ 
Table A.2 (continued)

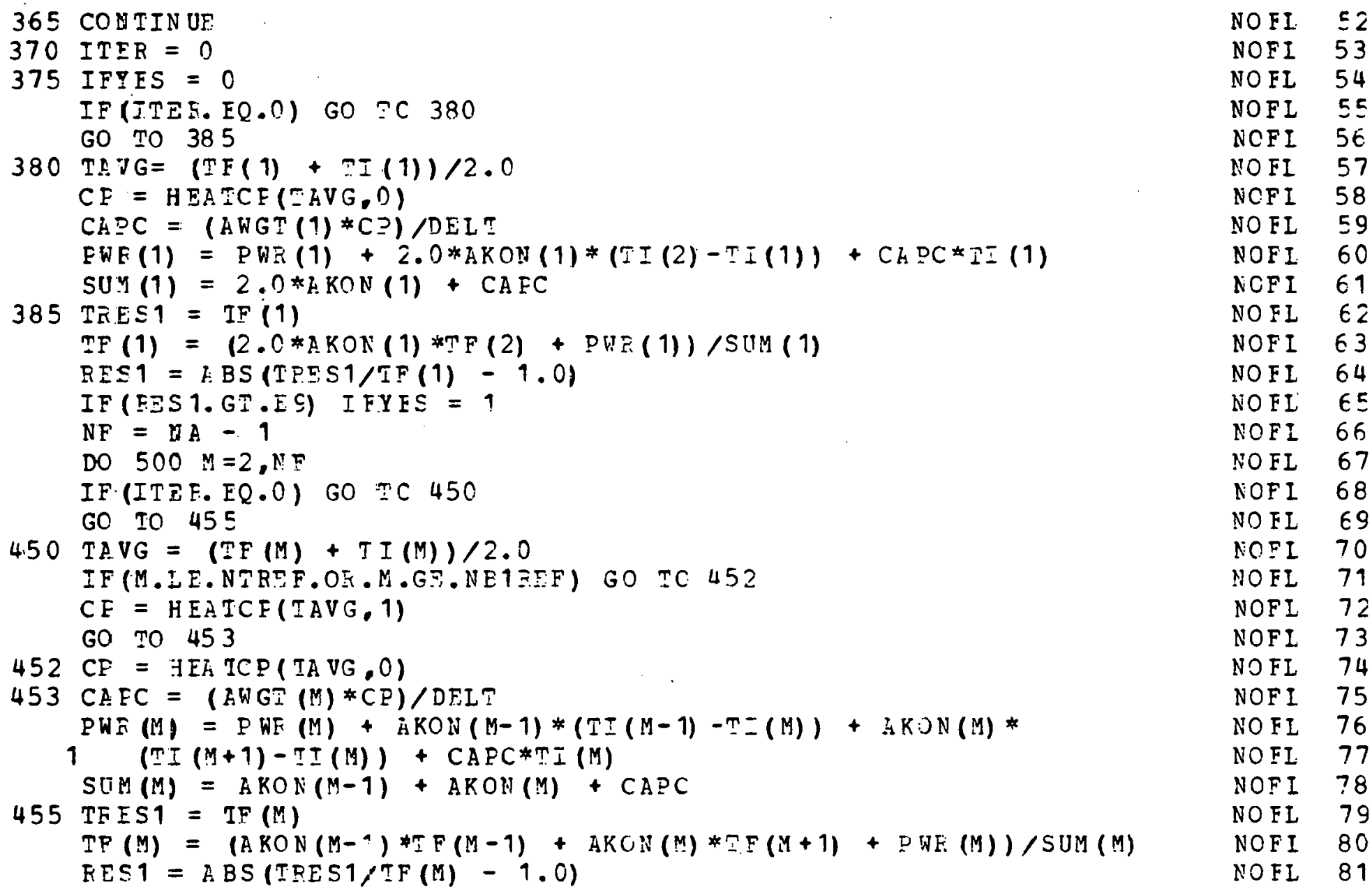

NOFI. 52

NOFI 53

NOFL 54

NOFI 55

NCFI 56

NOFI 57

NCFI 58

NOEI 59

NOFI. 60

NCFI 61

NOFI $E 2$

NOFI 63

NOFI 64

NOFI $\quad E 5$

NOFI 66

NOEL 67

NOFI 68

NOFI 69

NOEI 70

NOFI 71

NOFI 72

NOFI 73

NOFI 74

NOFI 75

NOFI 76

NOEI. 77

NOFI 78

NOFI 79

NOFI 80

NOFL 81 


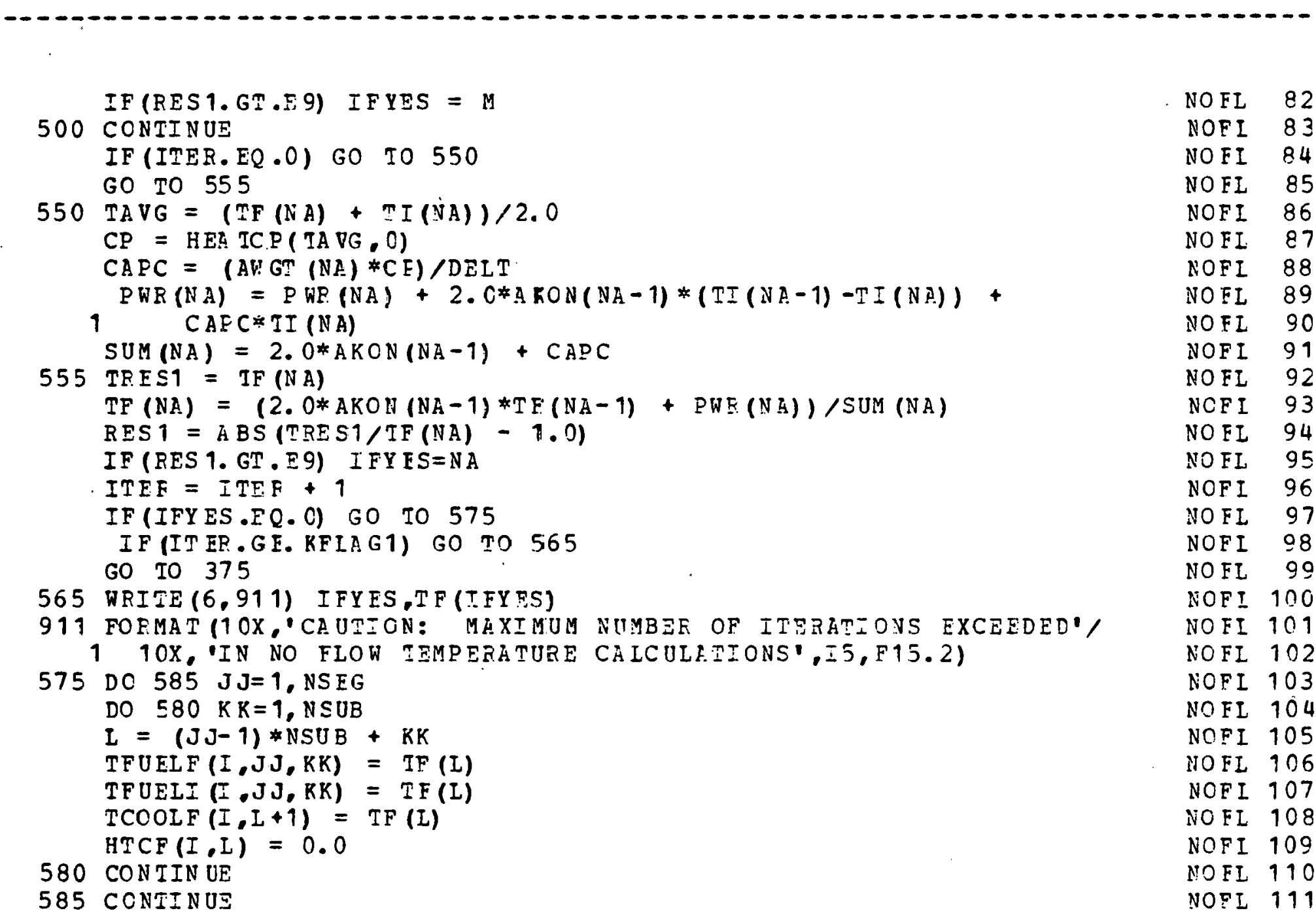

NOFL 82

NOFI 83

NOEI 84

NOFI 85

NOFI 86

NOEL 87

NOFI 88

NOEL 89

NOFI 90

NOFI 91

NOEL 92

NCFI 93

NOFI 94

NOFL 95

NOFI 96

NOFI 97

NOFI 98

NOFI 99

NOFI 100

NOEI 101

NOFI 102

NOF I 103

NOFL 104

NOFI 105

NOFL 106

NOFI 107

NOFL 108

NOFI 109

NOFI 110

NOPI 111 
SUBEOUTINE OUMPT2

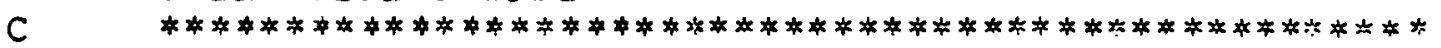

C THES SUBROUTINE IISTS THF OUETUF SUMMAEY OF THE PRESSUEF DEOPS IN C ESGIOH FIOWS

C $\quad$ C

COMMON, /CCERIS/ AKC (37), EKC (37), AKF $(37.1 C 0)$, IK:1(37),

1 KKE2 (37), AKF3(37), f.KG (37), ¿KT $(37,100)$

COMMON/OUTEI TIME, WTOT: WI (37), VF (37), =COOLE $(37,101)$.

1 TCOOIF $(37,101)$. TFUELE $(37,10,10)$, SFUELF $(37,10,10)$.

$2 \operatorname{SSP}(37,10,10)$

COMMON/INPUT 1/ AC(37), AOT(37), IPB1(37), SP32(37), APB3(37).

1 WGI $(37,1 \mathrm{C}, 10), \mathrm{BHT}(37,12,10)$

COMMON/ENFUT2/ DCS, DCI, ALCF(10), ALCT (10), DE.

FSDE

ES LP

$E \subseteq[F$

$P S[E$

BS DP

ESTE

PS IF

ESDE

PSLP

PSIP

ESDE

PS LP

ESDE

PS IP

1 DPE1, DPE 2, DPB 3, DPT

ESDE

CCMMON/ENPUT 3/ NCOI (37). NREG, NSEG, NSUS, NZOLT, NSTEPS, IQMAX.

1 iN STEP

COMMON/IN?UT 4/ SE, WP ZR, DKOX

COMMON IT NDUTS/ KTMAX, KQMAX, KFIOW, KFEIC, KITER, KIOUT

PS IP

PSDP

ESDE

COMMUN/INE OEE/ $21, E ?, E 3, E 4, E 5,86, E 7,38$, ES

PSIP

ESDE

FSIP

ESDE

PS IP

FSDE

COMMON/INEUT 8/ SSQR. SSW . HECP, SSTEN, SSC, PSS, EDBA

24

COMMCN/FAEY2/NOII, TIN, DEIT, SO (37)

ESIP 25 
WRITE (6,90 1)

901 FOEMAT (2 H1)

1 R E D $\quad$ S $O$ P

$52 \times, B$ B G T 0

F I 0

$S$ UTOT, EP

1 ' LB/HR' $9 \mathrm{X}$, 'PIENUM TO PLENUM ERESSORE DEOP = , F8.5,' FSIA'/) WRITE $(6,903)$

903 FORMAT (2 HO, 30X,'REGION FIOW INFORMATION',20X,

1

-ERESSURE DROP INFOAMA IOION $/ 1$

WRITE $(6,904)$

904 FORMAT (2HO 6X,'REGION',3X,'RADIAI', 7X,'REGION', 3X,'RATIO TC',

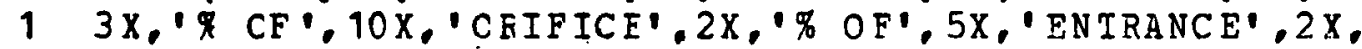

2 \% OF' $5 X^{\prime}$ 'CHANNEL' $3 X^{\prime}, \%$ OF') WRITE $(6,905)$

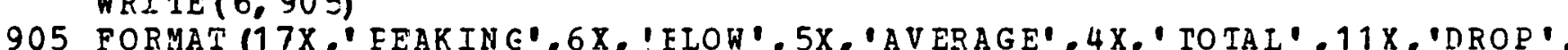

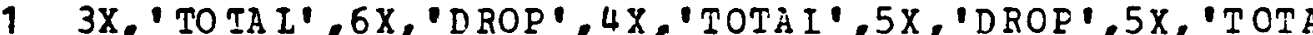
WRITE $(6,906)$

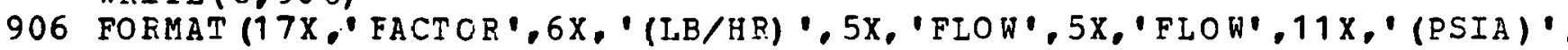

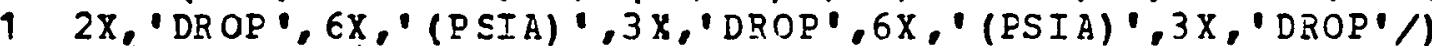

$\mathrm{FNC}=\mathrm{NCCLT}$

WAVG $=$ WTOT/FNC

DC $100 \quad I=1$, NR.EG

$P N C=N C O L(I)$

WRAI $=W F(I) /($ WAVG*FNC $)$

WPEF $=100.0 *$ F $(I) / W T O T$

ODPPER $=(O D P(I) / D P) * 100.0$

EDPPER $=($ EDP $(I) / D P) * 100.0$

$C D P E E R=(C D E(I) / I E) * 100.0$

WR ITE (6,907) I,PR (I), WF (I) WRAT, WEER, ODP(I), ODPPER, EDP(I), ELPPER,

1 CDP (I), CIPEER
PS IP 26

FSDE 27

PSIF 28

FSIP 29

FSDE 30

PS LP 31

PSDP . 32

ESDF 33

PS IP 34

PSDF 35

PSIP 36

FSDE 37

ESDE 38

PS LP 39

ESDE 40

PSDP 42

ESDE 43

PSIP 44

PSDP 45

PSIP 46

PS CP 47

PSDE 48

PSIP 49

FSDF 50

ESDE 51

PS [P 52

FSDF 53

PSDE 54

PS DP 55 
Table A.2 (continued)

100 CONTINUE

907 FOPMAT $(9 X, I 2,5 X, F 7,5,6 X, F 8,1,2 X, F 8.4,3 X, F 3,1,10 X, F 8.5$,

$12 X, F 4,1,6 X, F 7,5,2 X, F 4,1,6 X, F 7,5,2 X, F 4,1)$

RE: ORN

END

PSDF 56

PSEP 57

FSDE 58

PSIP 59

PS IP 60

SUBFOUTINE OUTDT 3 (I)

HOTS

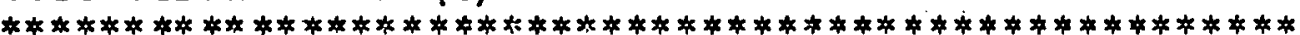

HOIS

THE SUESOUTTNE IISIS THE DEIAIIZD TEMEIRIMUSE DISTKIBUTION

HOIS

HOTS

FOF A RIVEN TEFUIIING REGION

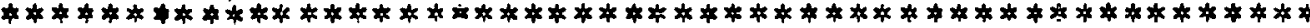

HOTS

COMMON/COFFIS/ AKC (37), AKC (37), AYF (37,100), BKE1 (37)

1 AKE2 (37), AKE3 (37), EKG (37), RKT $(37,100)$

COMMON DUTPT, TIMF, WTOT, WI $(37)$. WF $(37)$. ICOOLI $(37,101)$,

HOTS

HOTS

HOTS

H.TS

TCOOIF $(37,101)$, IFUEII $(37,10,10)$, TFUELF $(37,10,10)$ 。

$2 \operatorname{SSPW}(37,10.10)$

COMYON/ENEOT 1/ AC(37) A API(37), APB1 (37), BDB2(37), AEB3 (37),

HOIS 10

HOTS 11

1 WG? $(37,10,10)$. A HT $(37,10,10)$

HOIS 12

HOTS 13

COMMOK, INPCT2/ DCS, DCI, AICF (10), 户̈LCT (10), DP,

1 DER1, DEB2, CPB3, LPI

HOTS 14

COMMON/ENPUE3/ NCOL(37), NEUG, NSEG, NSUB, NCOLT, NSTEPS, ICMEX, 1 NSTEP

COMMON /INPCT 4/ SP, WPZE, AROX

COMMON/INPUT 5/ KTMIX, KQMAX, KFLOW, KFETC, KITEE, KIOUT

COMMON/INPOIE/ E1, E2, $\mathrm{E3}, \mathrm{E} 4, \pm 5, \mathrm{E} 6, \mathrm{E} 7,28, \mathrm{E}$

COMMON/SIGNRI/KFLAC1, KFIAG2,KFL IG 3,K FILG4,KFLLG 5, KFLÄG 6

COMMON IINP TT7/ RF, ICF, F1, F2, AIIT

COMMON/INPUT 8/ SSOI, SSWT, HECF, SSTI, SSC, PSS, PDBA

COMMON/INF OTS/ ER (37), DA $(10,10)$, ERE(37)

HOTS

HOTS

HOTS

HOIS

HoTs

HOIS

HOTS

HOIS

HOIS 


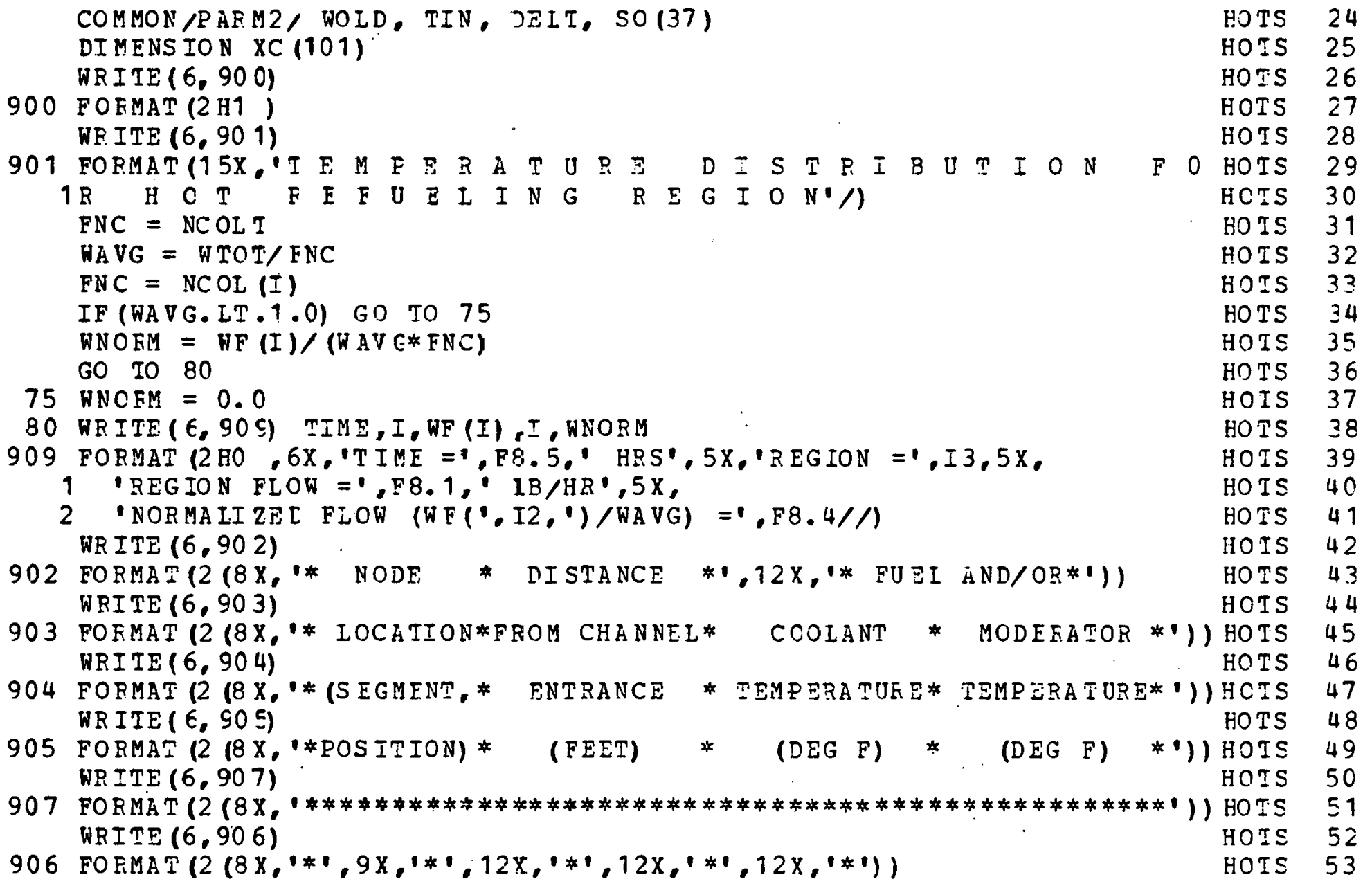


Table A.2 (cortinued)

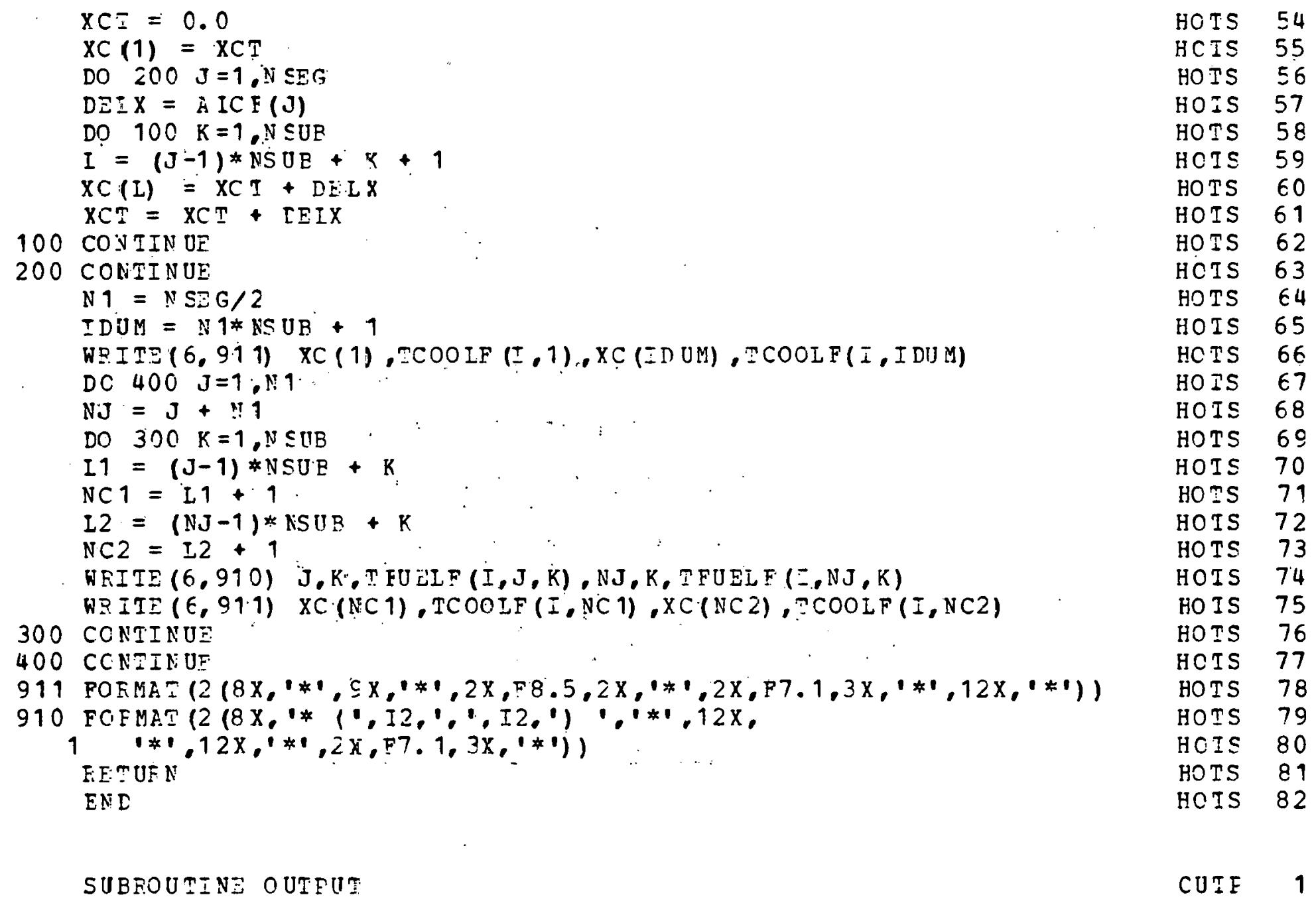




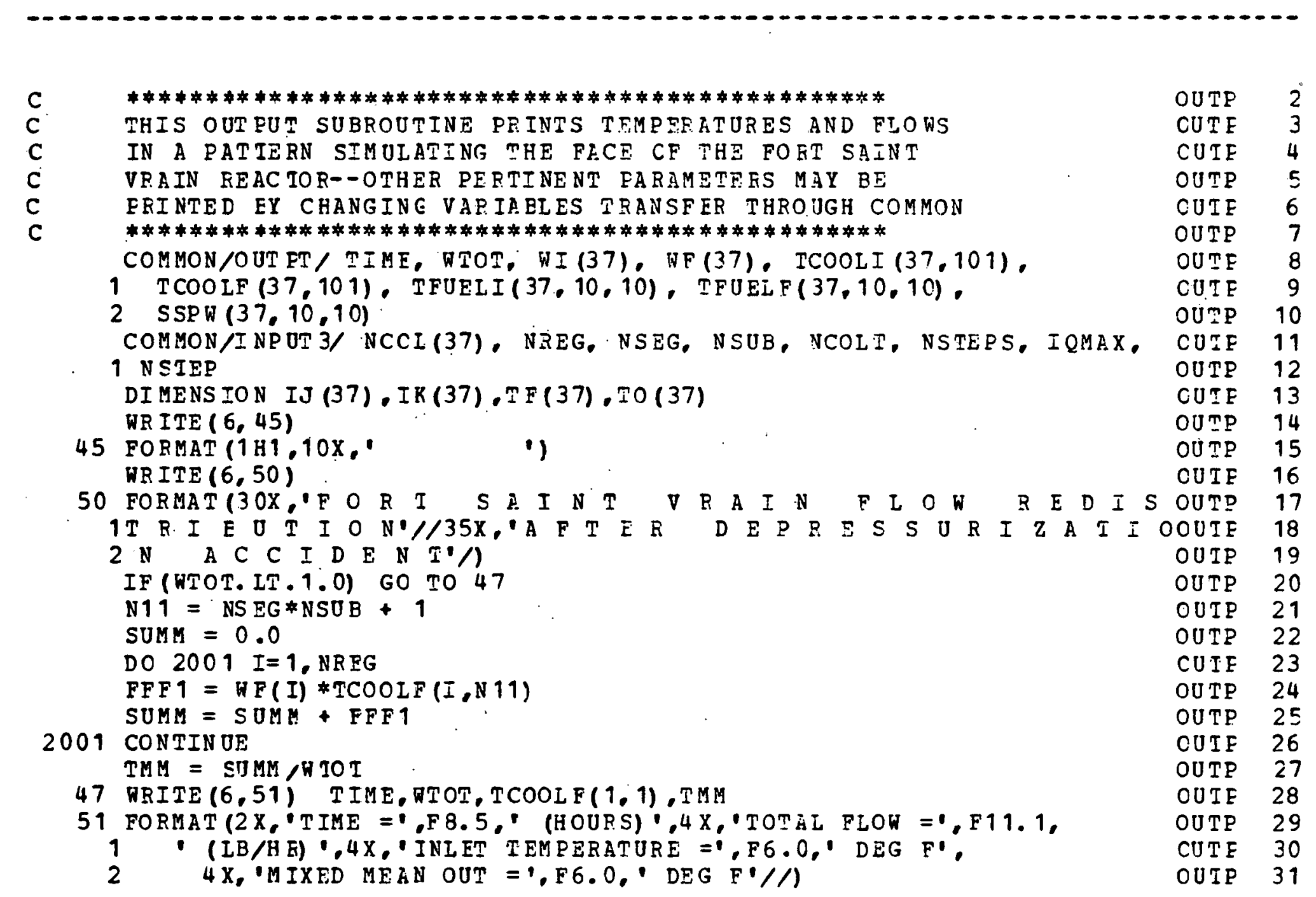


Table A.2 (continued)

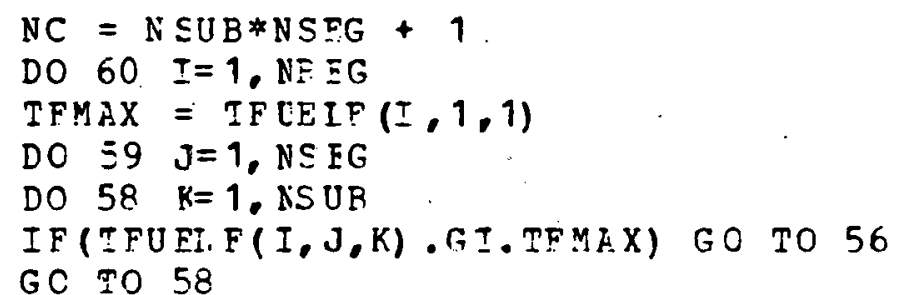

56 TFMAX = IF UEIF $(I, J, K)$

$I J(I)=J$

$I K(I)=K$

58 CONIIN UF

59 CONTINUE

$T F(I)=T F M A X$

$T O(I)=\operatorname{TCCOIF}(I, N C)$

60 CONIIN O:

$I F I G=1$

$I 1=35$

$I 2=36$

$I 3=37$

$I 4=20$

GO To 100

75 I1 $=29$

$I 2=28$

$I 3=27$

$I 4=2 E$

100 WPITP $(6,101) \pm 1, I 2, I 3, I 4$

101 FOEMAI $(27 X, 4(4 X$, REGEON $, .52,5 X))$

WRITE $(6,102)$ WF(I1), WE (I2),WF(I3),WF (I4)

102 FOEMLT (29X,4 ('FLOW $=9, F 9.2,3 X)$ )

104 FOEMET $(29 X, 4($ HE CUT $=0.56 . C, 5 X) / / 1)$

$\begin{array}{ll}\text { OUTP } & 32 \\ \text { OUTP } & 33 \\ \text { CUIP } & 34 \\ \text { OUTP } & 35 \\ \text { OUTP } & 36 \\ \text { OUTP } & 37 \\ \text { CUTF } & 38 \\ \text { OUTP } & 39 \\ \text { OUTP } & 40 \\ \text { CUIF } & 41 \\ \text { OUTP } & 42 \\ \text { OUIP } & 43 \\ \text { OUTP } & 44 \\ \text { CUIF } & 45 \\ \text { OUTP } & 46 \\ \text { OUTF } & 47 \\ \text { OUTP } & 48 \\ \text { CUTF } & 49 \\ \text { OUTF } & 50 \\ \text { OUTP } & 51 \\ \text { OUTF } & 52 \\ \text { OUTP } & 53 \\ \text { CUIF } & 54 \\ \text { CUTF } & 55 \\ \text { OUTP } & 56 \\ \text { OUIP } & 57 \\ \text { OUTP } & 58 \\ \text { CUTF } & 59 \\ \text { CUTF } & 60 \\ \text { OUTP } & 61 \\ & \end{array}$


WRITE $(6,103)$ IJ (I 1), IK (I1), IJ (I2) , IK (I2), IJ (I3), IK (I3) ,

$125 I 1=34$

$I 2=18$

$I 3=19$

$I 4=.8$

$I 5=21$

GO TO 200

$150 I 1=30$

$I 2=14$

$I 3=13$

$I 4=12$

$I 5=25$

200 WRITE $(6,201)$ I1,I2,I3, I4, I5

201 FORMAT $(18 X, 5$ (4X, REGION I, I $2,5 X))$

WFITE $(6,202)$ WF (I1),WF (I2), WF (I3), WF (I4), WF (I5)

202 FOSMAT $(20 X .5$ ('FIOW $=1$, F9. 2, 3X)

204 FORMAT $(20 \mathrm{X}, 5(\mathrm{HE}$ OUT $=1, \mathrm{~F} 6.0,5 \mathrm{X}) / / /)$

WRITE $(6,203)$ IJ (I 1),IK (I1),IJ(I2),IK(I2),IJ (I3),IK (I3),

1 IJ(I4),IK.(I4), IJ (I5),IK (I5)

203 FOCMAT (20X,5 ('IOCATION',2X,I?,1, , I $2,3 \mathrm{X})$ )

WRITE (6.205) TF(I1),TF (I2),TF(I.3), TE(I4), TF (I5)

CUTF 87

OUTP 88

OUTE 89

205 FORMAS $(20 X, 5$ ('FUEL $=1 . F 6.0,5 X))$

CUTE 90

WRITE $(6,204)$ TO(I 1), TO(I2), TO(I3), TO (I4), TO (I5)

CUTP 91 
IF (IFEG. EQ.1) GO $\because C 225$

IF (IEEG.EQ.2) GO TO 75

STOF

$225 I 1=33$

$I 2=17$

$I 3=7$

$14=2$

$I 5=9$

$I 6=22$

GO To 300

$250 I 1=31$
$I 2=15$

$I 3=5$

$I 4=4$

$I 5=11$

$I 6=24$

300 WRITE $(6,301)=1, I 2, \mp 3, \mp 4, \mp 5, I 6$

301 FOEMAE $(9 X, 6(4 X$, 'EEGTON $1,2.5 X))$

WลIT工 $(6,30 \bar{z})$ WF $(I 1), W F(I 2), W F(I 3), W F(I 4), W F(I 5), W F(I 6)$

302 FORMAT $(11 \mathrm{X}, 6$ ('FICW $=1, F C .2,3 \mathrm{X})$ )

304 FCPMAT $(11 \mathrm{X}, 6$ (' HE CUT $=?, \mathrm{~F} 6.0,5 \mathrm{X}) / / 1)$

WFITE $(6,303)$ IJ (I 1), IK (I1), IJ (I2),IK (I.2),IJ(I3), IK (I3),

1 IJ(I4),IK(I4),IJ(I5),IK (I5), IJ (I6), IK (I6)

303 FOEMAT $\left(11 \mathrm{X}, 6\right.$ ('IOCATION $\left.\left., 2 \mathrm{X}, \mathrm{I} 2,0^{\prime}, 0, \pm 2,3 \mathrm{X}\right)\right)$

WEITE(6,30S) TF(I 1), TF (T2), TF (I3),TF (I4),TF (I5), TF (I6)

305 FOGMAT $(11 \mathrm{X}, 6$ ('FUII $=1, \mathrm{~F} 6.0,5 \mathrm{X})$ )

$W \equiv T T E(6,304)$ TO(I 1), TO (T 2), TO(I3), TO(I4), TO(I5), TO(I6)

IP (IREG.EQ.1) GO TC 350

IF (IREG. EQ.2) GO IC 150

STOP

$\begin{array}{rr}\text { CUTE } & 92 \\ \text { OUIF } & 93 \\ \text { OUTP } & 94 \\ \text { CUIT } & 95 \\ \text { OUTP } & 96 \\ \text { CUIF } & 97 \\ \text { CUTF } & 98 \\ \text { OUTP } & 99 \\ \text { OUIF } & 10 C \\ \text { OUTP } & 109 \\ \text { CUTE } & 102 \\ \text { OUTP } & 103 \\ \text { OUTP } & 104 \\ \text { CUTE } & 105 \\ \text { OUTP } & 106 \\ \text { OUTF } & 107 \\ \text { OUTP } & 108 \\ \text { OUTE } & 109 \\ \text { OUTP } & 110 \\ \text { OUTP } & 11.1 \\ \text { CUTE } & 112 \\ \text { OUTP } & 113 \\ \text { OUTP } & 114 \\ \text { CUTE } & 115 \\ \text { OUTP } & 116 \\ \text { OUTF } & 117 \\ \text { OUTP } & 118 \\ \text { OUTP } & 119 \\ \text { OUTP } & 120 \\ \text { OUTP } & 121\end{array}$




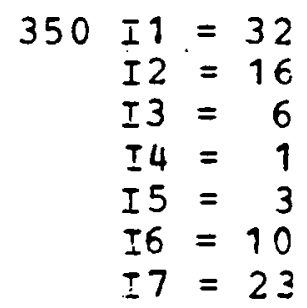

$\begin{array}{ll}\text { CUTE } & 122 \\ \text { OUTP } & 123 \\ \text { CUTE } & 124 \\ \text { OUTE } & 125 \\ \text { OUTP } & 126 \\ \text { CUTE } & 127 \\ \text { OUTP } & 128 \\ \text { OUTE } & 129 \\ \text { OUTP } & 130 \\ \text { CUTE } & 131 \\ \text { OUIE } & 132 \\ \text { OUTP } & 133 \\ \text { CUIF } & 134 \\ \text { OUTP } & 135 \\ \text { OUTP } & 136 \\ \text { OUTE } & 137 \\ \text { OUTP } & 138 \\ \text { OUIE } & 139 \\ \text { OUTP } & 140 \\ \text { OUTP } & 141 \\ \text { OUTP } & 142 \\ \text { OUIP } & 143 \\ & \\ \text { CIPC } & 1 \\ \text { CA PC } & 2 \\ \text { CEPC } & 3 \\ \text { CAPC } & 4 \\ \text { CAEC } & 5 \\ \text { CAEC } & 6\end{array}$


Table A.2 (continueć)

DATA $Z, F, G, H / 3.38,2.74 E-2,-4.88 \mathrm{E}-6,-0.146 \mathrm{E} 6 /$

DFIA DEN SG,DENSF, VOIG, VOIF/107.0,107.0.12.532,4.8956/

$T=m F+459.67$

$A G C P=E+B * T+C * T * T+D * T * T * T$

IF (IFIAG.EC. O) GO TO 50

ROFCPF $=E+F * T+G * T * T+H /(T * T)$

GMiSS = DENSG*VOLG

FMASS = LENS F*VOIF

HEATCP $=($ GMAS* $R C P+F O W C P F * V C L F) /(G M A S S+F M P S)$

RETURN

50 HELTCE = AGCD

BEIUEN

END,

CA EC 7

CEPC 8

CAEC 9

CSPC 10

CAEC 11

CAEC 12

CAFC 13

CAFC 14

CP.PC 15

CA EC 16

CEFC 17

CAPC 18

CẢEC 19

FUNCTION PWFRKC (TIME,DEIT)

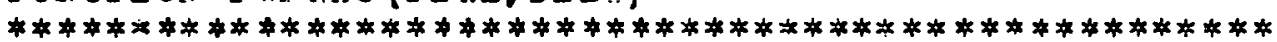

PWFR

PWFR

FUNCTION PNFFAC CAICULATES THE AVERRGE FRACIIONBI

POWER REMP̃ INING BETWEEN THE GIVEN BOUNDING TIMES

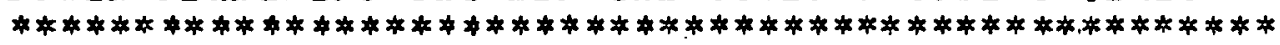

DATA $A . B, C / 0.128,0.0003796 .0 .739 /$

$T 2=I M E * 36 C 0.0$

$\mathrm{T} 1=\Xi 2-\mathrm{EEIT} * 3600.0$

$S 1=(I 1+B) * C$

$S 2=(T 2+B) * * C$

PWFRLC $=(A *(S 2-S 1)) /((T 2-T 1) * C)$

RET URN

END

EWFE

PWFR.

PWER

EWFF

FW FR

FWF

DNFE

PWFE

EWFF

PW F

FWF 


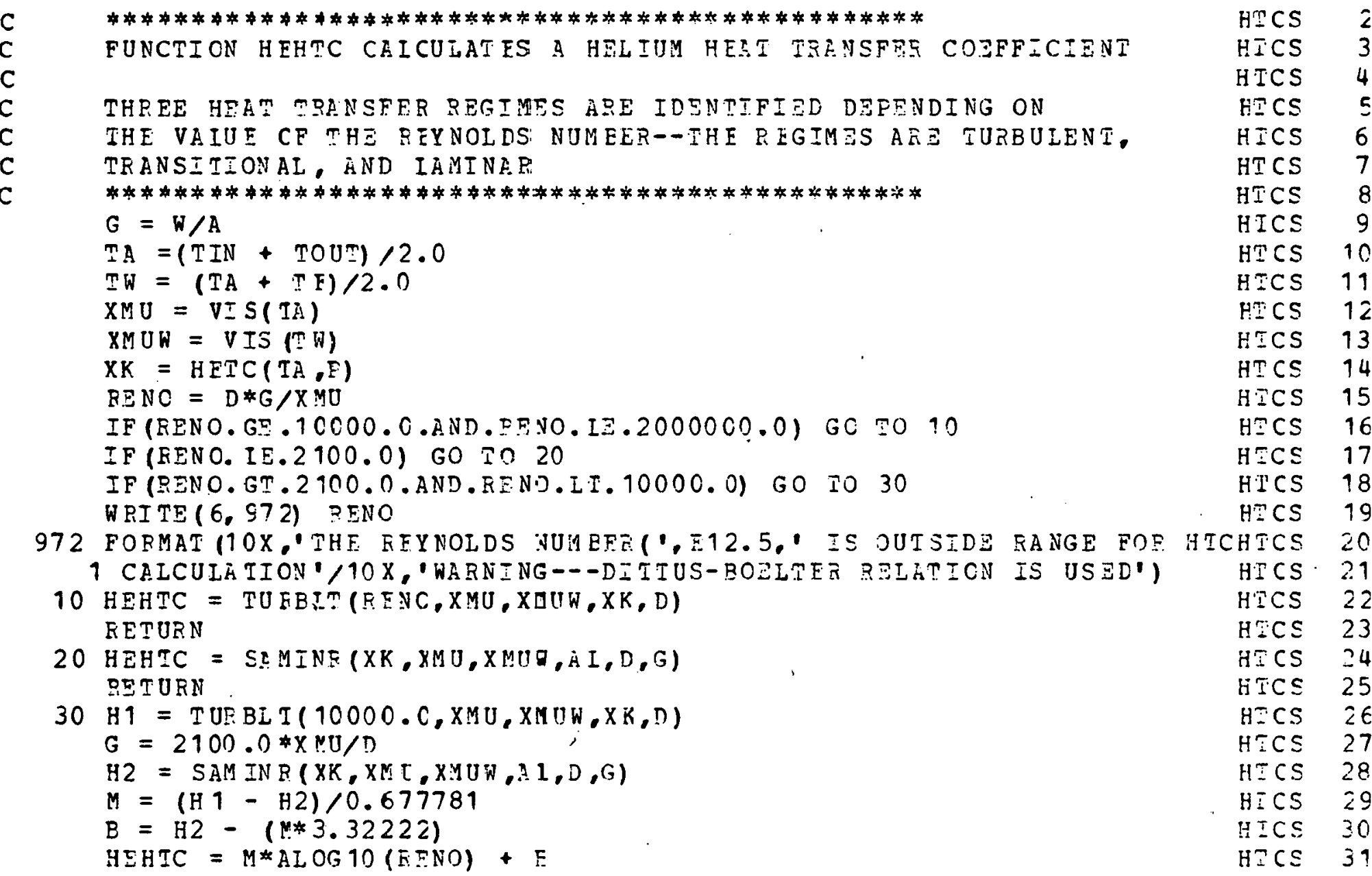


Table A.2 (continued)

RETORN

H ¿CS

HICS

32

EN L

$\begin{array}{lr}\text { TURE } & 1 \\ \text { TURB } & 2 \\ \text { TUEE } & 3 \\ \text { TUEB } & 4 \\ \text { TURB } & 5 \\ \text { TUSE } & 6 \\ \text { TUEB } & 7 \\ \text { TUEE } & 8 \\ \text { TUEB } & 9 \\ \text { TURE } & 10 \\ \text { TUEB } & 11 \\ \text { TUEE } & 12 \\ \text { TUFB } & 13 \\ \text { TUFB } & 14\end{array}$

FUNCTION SEM ENE (XK,XMU, XMUW, AI,D,G)

IEMF

I M MR

FUNCTION SAMINR CAICULATES IAMINAS YEAT TRANSFZF

COEFFICIEN IS BASED ON Aं GEAETZ NUMEEF COREEIATICN

IA M F

IL ME.

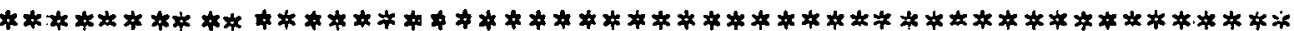

LA MF

$W=0.7854 * D * D * G$

$I \bar{M} M$

$G Z=(W * 1.2425) /(X K * A L)$

$R=G Z * .333333$

ISMF

IA MF

$S=2.0 *(X M U / X M U V) * * .14$

IAMR

$X N O N O=F * S$

I. $M F$ 
$S A M I N R=X R * X N U N O / L$

RETURN

IAM 13

END

HE TC

FUNCTI ON HETC C $(T, P)$

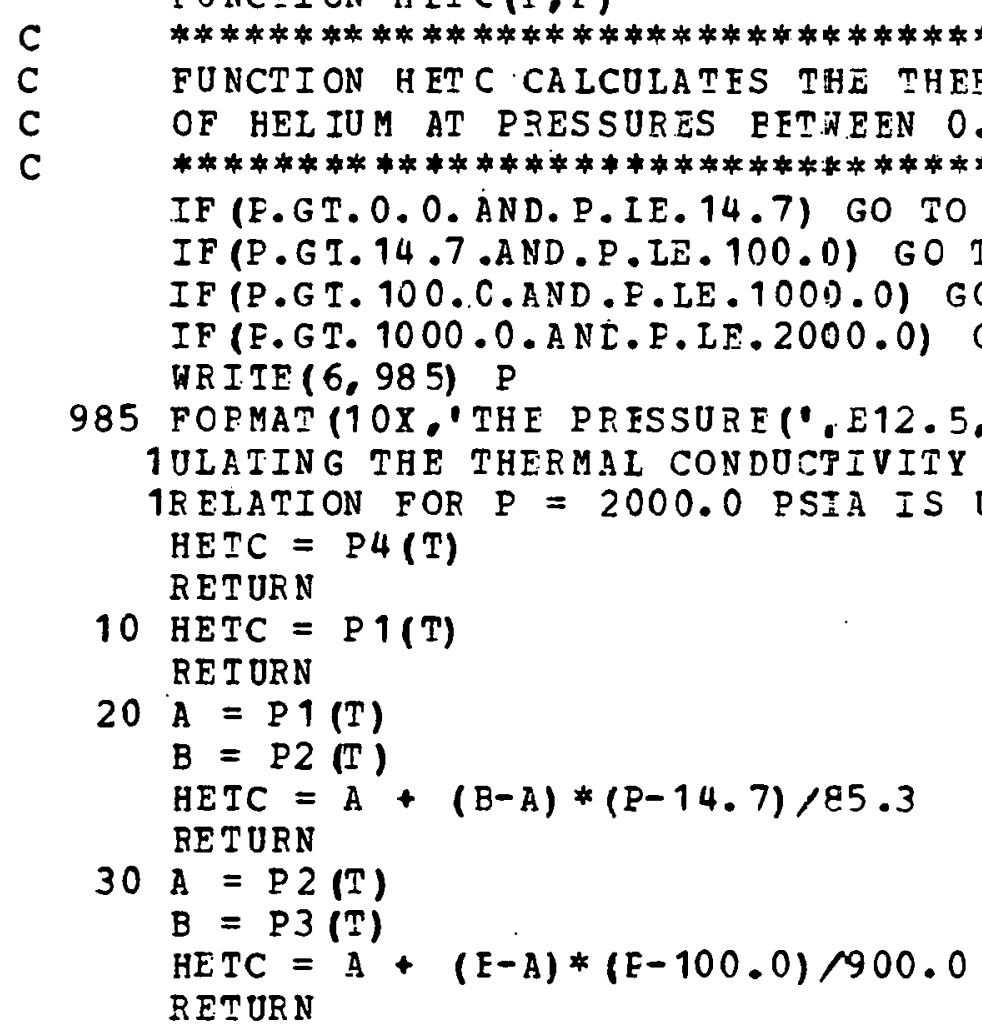


Table A.2 (cortinued)

$40 \mathrm{~A}=\mathrm{P3}(\mathrm{F})$

$B=24(m)$

HETC $=A+(E-A) \star(E-1000.0) / 1000.0$

RET URN

END

$\begin{array}{ll}\text { HETC } & 26 \\ \text { HETC } & 27 \\ \text { HETC } & 28 \\ \text { HETC } & 29 \\ \text { HETC } & 30\end{array}$

FURCIION P $1(T)$

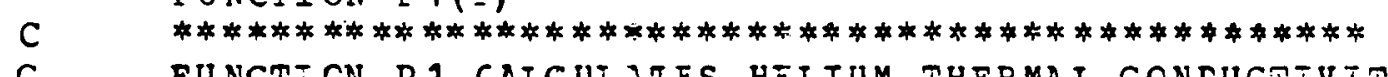

K1FS

K1 ES

FUNCTICN D 1 CAICUIAIES HEIIUM THERMAI CCNLUCTIVITY

K 1 PS

AT 14.7 FS IA

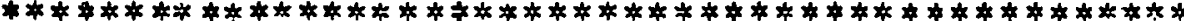

K1 ES

K 1 PS

$\mathrm{P} 9=.0809175+9.9936 \mathrm{E}-5 * \mathrm{E}-1.10025 \mathrm{E}-8 * \mathrm{~T} * \mathrm{~T}$

RETUPN

EN D

K1FS

K1 ES

K1FS

\section{FUNCTICN P2 (T)}

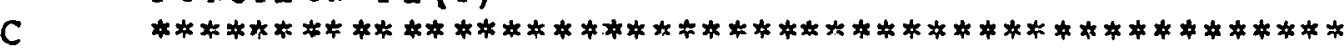

K2FS 1

K2FS 2

K2FS 3

FUNCTICN P 2 CAICUIAIES HEITUM THESMAI CONCUCTTVITY

K2 ES

K 2 PS

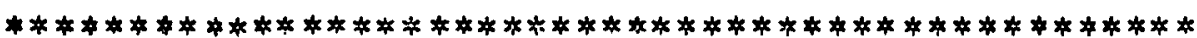

K2 FS

$\mathrm{P} 2=.0834957+1.00842 \mathrm{~F}-4 * \mathrm{~T}-1.13508 \mathrm{E}-8 * \pi * \pi$

EET URR

END

K2 ES

K 2 PS

FONCTION D I ( I)

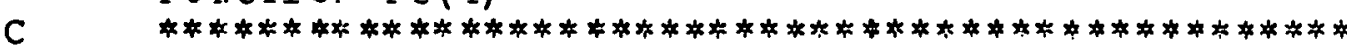

C FUNCTIOA F 3 CELC UIATES HFIIUM IHERMAI CCNDUCOEVITY 


\section{FUNCTION P4(T)}

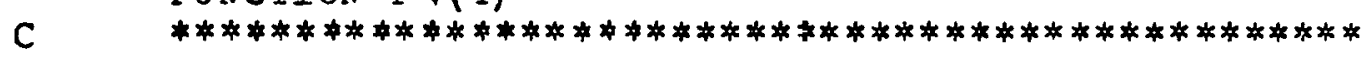

C FUNCTION P 4 CALCUIATES HELTUL THERMAL CONDOCTIVI?Y

C AT 2000.0 PSIA

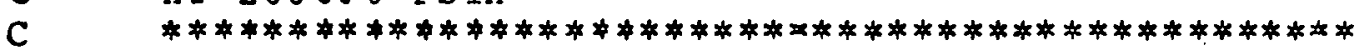
$P 4=.0869 C 6 E+1.03092 E-4 * T-1.27824 E-8 * T * T$ RETURN

END

\section{FUNCTION RENUM (W, A, T, D, P, N)}

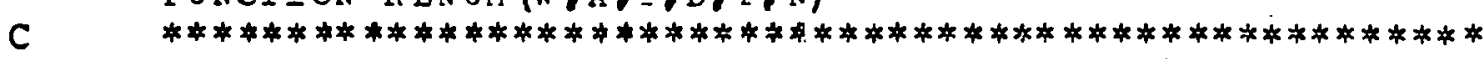

K4 FS

\section{FUNCTION EENUM CAICULATES A REYNOLDS NUMBIR FOR A}

C ARBITRARILY SHAPED DUCT

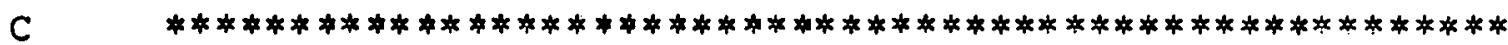

C CAICUIATE EEYNOLDS NUMBFR FOR CIRCULAR (N=1, DEFAUIT) AND

C. NON-CIRC OLAR $(N=0)$ CHANNEIS

IF (N.NE.O) GC TO 10

$D E=4 * 2 / P$

GO TO 20

$10 D E=D$

$20 \mathrm{G}=W / \mathrm{A}$

$V=V I S(T)$

$\begin{array}{lr}\text { EENO } & 1 \\ \text { FENO } & 2 \\ \text { IRENC } & 3 \\ \text { RENO } & 4 \\ \text { RENO } & 5 \\ \text { RENC } & 6 \\ \text { RENO } & 7 \\ \text { PENC } & 8 \\ \text { PENO } & 9 \\ \text { EENC } & 10 \\ \text { RENO } & 11 \\ \text { RENO } & 12 \\ \text { PENC } & 13\end{array}$




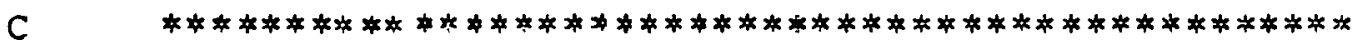
$T E=T+459.67$ IF (F.GI.0.0.RND.F.IE.1000.0) GO TC 10 WPITE $(6,909) \quad P$

909 POEMAT $110 \mathrm{X}$, THE PFESSUEE $\left(', \$ 12.5,{ }^{\prime}\right)$ IS CUISIDE PANGE OF AEDLECAELENS 1 ILITY OF $\% 10 X, 1$ ILEAT GAS LAW WHEN CELCULATING SHE DENSTTY OF HELIDENS $2 U M+/ / 1.0 X, ' C L U T I O N-$ THP IDEAL GAS LAH IS USED')

10 IF (T.GI.C.C.S.ND.T.IE.1600.0) GO TO 20

20 HEIEN $=0.37303 * \mathrm{~F} / \mathrm{TR}$ FET URN

END 
WRITE $(6,903)$ KENO $\quad$ FRIC 9

STOP $\quad$ EP.IC 10

903 FORMAT (10X 'THE REYNOLDS NUMBER ('.E12.5,') IS OUT OF ERNGE FOF TFEIC 11

1HE FRICTION FACTOF CALCULATION') $\quad$ TEIC 12

10 FRICTN $=16.0 /$ RENC $\quad$ ERIC 13

RET URN

20 FRICTN $=0.01$

RETURN

$30 \mathrm{FRICTN}=0.00140+0.125 /(R \equiv N O * .32)$

RETURN

END

FRIC 14

FEIC 15

FFIC 16

FRIC 17

FFIC 18

FRIC 19

FUNCTION CCVTRC (EENO, SA, SE)

DIMENSION $X(11), Y(11)$

DATA $X / 0.0,0.1,0.2,0.3,0.4, C .5,0.6,0.7,0.8,0.9,1.0 /$

DATA Y $/ 0.611 .0 .612,0.616,0.622 .0 .631 .0 .644 .0 .662 .0 .687,0.722$,

1

SIGMA $=\quad 0.781$.

$S 2=S I G M A$ S IGMA.

DO $5 I=1,11$

$I F(X(I)$. IE.SIGMA) MIN $=I$

IF (X(I). GT.SIGMA) GO TO 8

5 CON TIN UE

$8 M A X=M I N+1$

$D E L Y=Y(M A X)-Y(M I N)$

$D E I X=X(M A X)-X(M I N)$

$C J=Y(M I N)+D I Y *(S I G M A-X(M I N)) / D E L X$

$\mathrm{CJ} 2=\mathrm{CJ} * \mathrm{CJ}$

IF (RENO.GT.0.0.AND.FENO.IE. 2100.0$)$ GO TO 10

CNTR 1

CNIF 2

CNTR 3

CNTR 4

CNIE 5

CNTE 6

CNIF 7

CNTR 8

CNTR 9

CNTF 10

CNTR 11

CNTE 12

CNIE 13

CNIR 14

CNIE 15

CNTR 16

CNIE 17 
mable A. 2 (cortinued)

IF (RENO.GT.2100.0.AND.FENO.II.1.0I8) GO TO $20 \quad$ CNTE 18

WRITI $(6.904)$ EFNO,SA.SB $\quad$ CNTE 19

904 FOBMAT (10X, THE FEYNOLDS NUMBER (',512.5,') IS OUTSEDE OF THE RANCNTR 20

1GE FOR CCNTRACEION LOSS .2510.31 CNTR 21 STCF

$10 \mathrm{BETH}=1.33$

$X I A M=1.00$

GO TO 30

20 BEIA $=1.00$

$X I R M=1.0 C$

30 CONTRC $=((1.0-X I Z * 52 * C J 2-2 .(* 0 J+2.0 * E D A *(J 2) /(J 2)-$

1 $(1-52)$

RETUR IS

ENT

EN D

CNIE 22

CNME 23

CNIE 24

CNTE 25

CNIE 26

CNIR 27

CNTF 28

CNIF 29

CNTP. $\quad 30$

CNIE 31

CIIF. 32

PUNCTION TXPYNS(EENO, SE, SB)

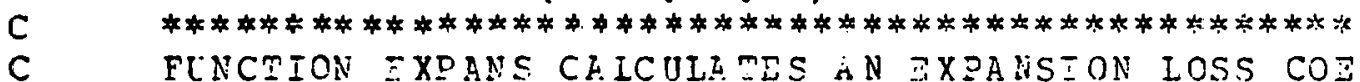

EXPN 1

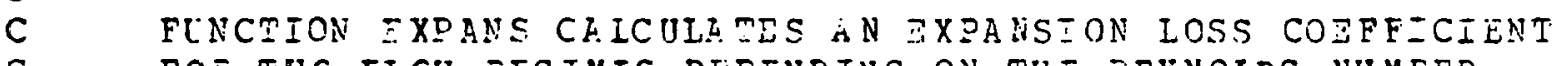

EXEN

EXPN

FEE INC FICV REGIMES DEEENDING ON THE FFYNOLDS NUMEER

EXPN

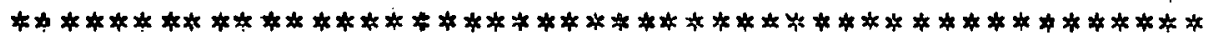

IE (SA.GT.SE) $G 0$ TG 10

IF (FENC. GT . C.O. ENI.E.SNO.IF. 2100.0) GO TO 20

EXEN

EXEN

IF (R.ENO. GT .2100.0. AND.RENO.II.1.0J8) GO TC 30

EXEN 7

10 HRITE $(6,905)$ FENC,SA,SB

STOP

905 FOFMAT (10X,'THE PEYWOLDS NUMBER (',F१2.5,') IS OUTSEDE RENGE FOR

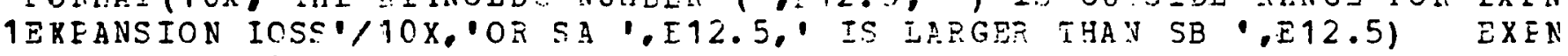

EXEN

EXEN

EXEN

20 EXPANS $=1.0-2.6 \in 7 *(S t / S B)+(S B / S E) * 2$ 


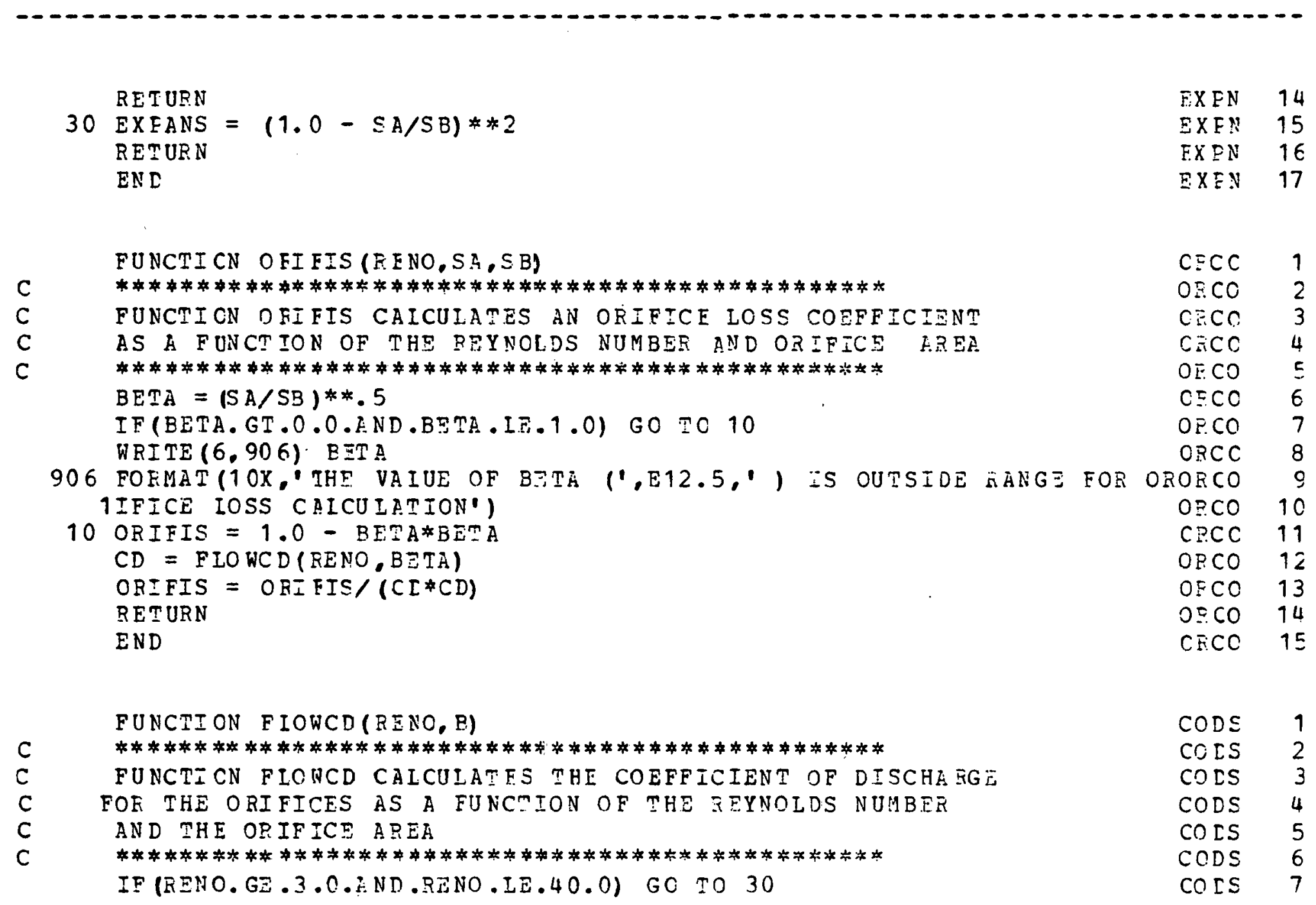


IF (EFNO.GT . 4O.O.END. PENO.I-

IF (FENO. GE. 100.0.AND.PFNO.IF.400.0) GO SO 50

IF (EINO.GE.400.0. SND.ESNO.IE.1000.0) GO TC 50

IF (ES:C. GE.1000.0.AND. BFNO.IE. 2000.0) GOTO 70

IF (EENO.GE.2000.0.hND. SENO.LE.4000.0) GO TO 80

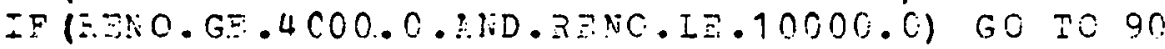

IF (EEYC.GE.1COCO.0.AND. ENNO.IF.1.UZR) GO DO 100

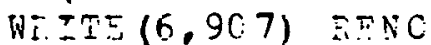

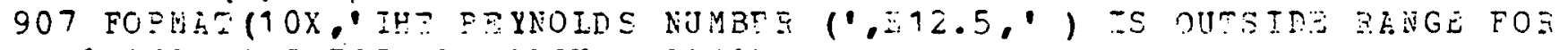

1FICU CEZFFICIEN" (AICULAETON') STCD

30 FIOWCD $=C[1(E)+(C D 2(D)-C D 1(B)) *(R E N O-3.0) / 37.0$ SE: USN

40 FICWCD $=\operatorname{CD2}(P)+(C D 3(B)-C D 2(B)) *(27.00-40.1 \% 6 C .0$ BETUFR

50 TIOWC $=$ CD.3 (B) $+(C D 4(\bar{S})-\operatorname{CD} 3(B)) *($ FTNO -109.$) / 300$. Engu:Bis

50 FICWCD $=C L 4(B)+(C D 5(E)-C D 4(B))=(2 D N O-400) /$.600 . SETU?:

70 FICWCI $=$ CI5 (B) + (CDE (E) - CD5 (B)) $*($ PNO -1000.1$) / 1000$. $\bar{K} \equiv \mathrm{T} U \mathrm{~N}$

$8 C$ FTCRCT: $=\operatorname{CDE}(R)+(C D P(E)-\operatorname{CDE}(B)) *(E D N O-2000.1 / 2000$. FETUE:

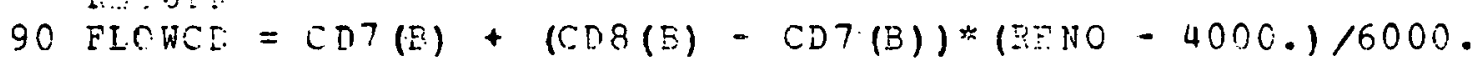
SE: UE:

$100 \mathrm{FIONCD}=\operatorname{CDE}(E)+(\operatorname{CDg}(B)-\operatorname{CD} 8(B)) *(E D N O-1.054) / 9.999: 7$ ETTU:

END

$\begin{array}{lr}\text { COLS } & 8 \\ \text { CODS } & 9 \\ \text { COIS } & 10 \\ \text { CODS } & 11 \\ \text { COIS } & 12 \\ \text { COIS } & 13 \\ \text { COLS } & 14 \\ \text { CODS } & 15 \\ \text { COIS } & 16 \\ \text { CODS } & 17 \\ \text { CODS } & 18 \\ \text { COIS } & 19 \\ \text { CCDS } & 20 \\ \text { CODS } & 21 \\ \text { CODS } & 22 \\ \text { CODS } & 23 \\ \text { COIS } & 24 \\ \text { CODS } & 25 \\ \text { COIS } & 26 \\ \text { CODS } & 27 \\ \text { CODS } & 28 \\ \text { COIS } & 29 \\ \text { CODS } & 30 \\ \text { COIS } & 31 \\ \text { CODS } & 32 \\ \text { CODS } & 33 \\ \text { COIS } & 34 \\ \text { CODS } & 35\end{array}$




\section{FUNCTION CD2 (B)}

\section{C $\quad$ C *********************************************4}

C2DS 1

FUNCTION CL2 CALCUIATES THE COEFFICIEN

AI REYNOIDS $=40.0$

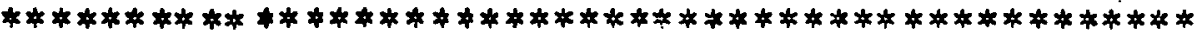

$C D 2=.713844-.257462 * B+.531716 * B * B$

RETURN

END

\section{FUNCTION CD3 (B)}

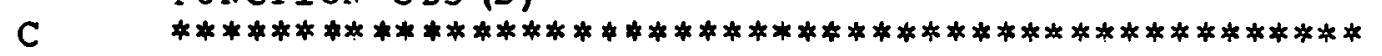

C FUNCTICN CD3 CALCUIATES THE COEFFICIENT OF DISCHARGE

C AT REYNOIDS $=100.0$

C

$C D 3=.698708-.36874 * \mathrm{~B}+.968407 * \mathrm{~B} * \mathrm{~B}$

RETURN

EN D

C3 DS

C 3 IS

C3DS

C3 CS

C 3 IS

C3DS

C3ES

C3 DS

FUNCTION CD4 (B) 


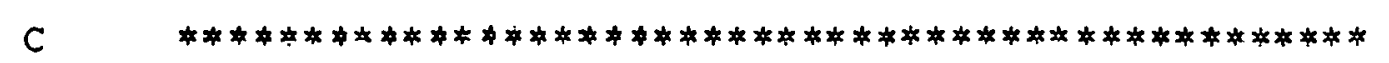

C FUNCTICN CIA CALCUIATES THE COEFFICIENT OF DISCHARG

C AT REYNOLDS $=400.0$

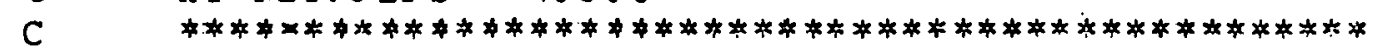

$\operatorname{CD} 4=.649126-.583087 * \mathrm{~B}+1.51107 * \mathrm{~B} * \mathrm{~B}$

RETUEN

END

$\begin{array}{ll}\text { C4LS } & 2 \\ \text { C4DS } & 3 \\ \text { C4 DS } & 4 \\ \text { C4DS } & 5 \\ \text { C4 DS } & 6 \\ \text { C4 DS } & 7 \\ \text { C4DS } & 8\end{array}$

FUNCTION CD5 (B)

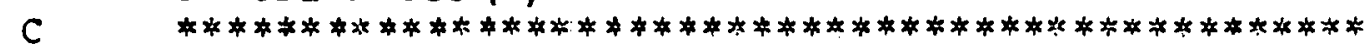

C FUNCTION CD5 CALCUIATES THF COEFFICIENT OF DESCHAFGE

C AT FEYNOLDS $=1000.0$

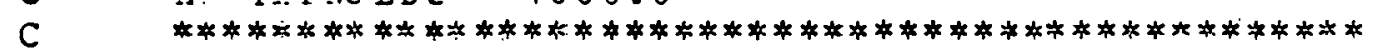

$C D E=.635 C 92-.7278 * B+1.72979 * B * B$

FTIUVN

END

$\begin{array}{ll}\text { C5DS } & 1 \\ \text { C5DS } & 2 \\ \text { C5DS } & 3 \\ \text { C5 CS } & 4 \\ \text { C5DS } & 5 \\ \text { C5 CS } & 6 \\ \text { C5DS } & 7 \\ \text { C5DS } & 8\end{array}$

FUNCTION CDG (B)

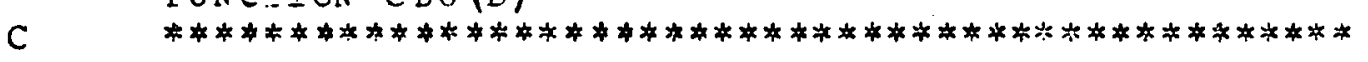

C6IS 1

FUNCIION CDG CAICUIATES IHE COEFFICIEN OF DISCHARGE

C6LS

C6IS

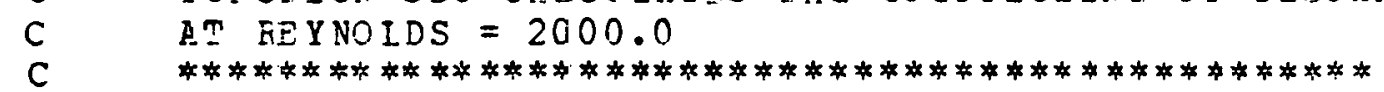

$\mathrm{CDE}=.64464 \bar{Z}-.792987 * \mathrm{~B}+1.70455 * \mathrm{~B} * \mathrm{~B}$

KE.T.USN

EN I.

C $6 \mathrm{DS} \quad 4$

CEIS. 5

C6IS 6

C6DS 7

FUNCTION CIT (B)

C7IS 1 


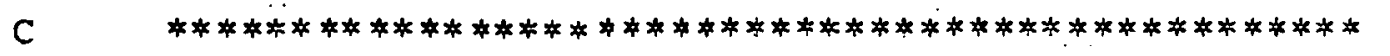

C FUNCTION CD7 CALCUIATES THE COEFFICIENT OF DESCHAEG AT REYNOIDS $=4000.0$

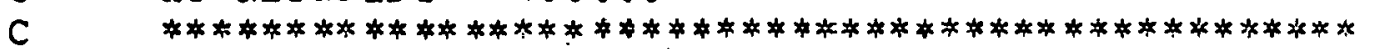

$C D 7=.6 C 5351-. \equiv 42319 * E+.893482 * B * B$

FET URN

EN D

$\begin{array}{ll}\text { C7DS } & 2 \\ \text { C7IS } & 3 \\ \text { C7DS } & 4 \\ \text { C7DS } & 5 \\ \text { C7IS } & 6 \\ \text { C7DS } & 7 \\ \text { C7DS } & 8\end{array}$

FUNCTION CD8 (B)

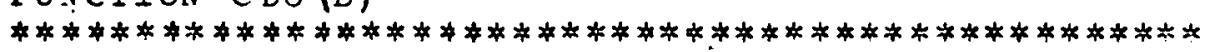

C8 $[S$

C8IS

C8DS

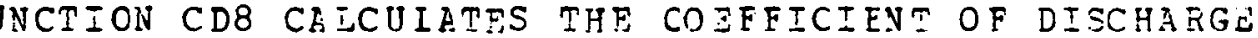

AI FFYNOLDS $=10000.0$

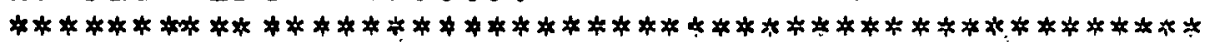

$C D 8=.5 \subseteq 9747-.225927 * B+.620089 * B * B$

EETURN

CR. LS

C8DS

C8 IS

C8 [S

END

CBDS

EONCTION CD9 (B)

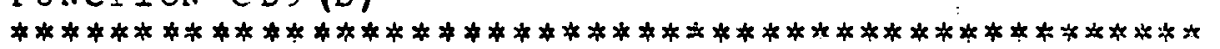

C9DS

Cors

C9IS

FUNCTICN CI9 CAICUIATES THE COEFFICIENT OF DISCHISGE

CQDS

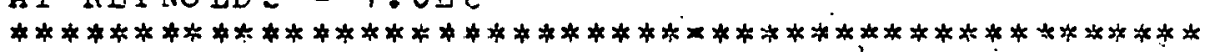

$C D 9=.61$

RETUSN

END

C9LS

C9ES

C9LS

CODS 
mable A.3. Iisting of FIODIS Input Data For a IEDA

\section{$\varepsilon$ CORE}

RGWGTS $=2990.0,6 * 1995.0,2737.0,451.1,792.0$, RG WG TB $=2140.0 .6 * 1409.0,1917.0 .451 .1,792.0$, VOLS $=5.8987,6 * 3.9408,5.8987,0.4256,0.7479$, VOL $B=4.1976,6 * 2.8042,4.1976,0.4256,0.7479$, $\varepsilon E N D$

$\&$ COOLNT

DCOOLS $=.500$, $D C O O I I=.625$,

$A I C F=3.9 .6 * 2.602,3.9,0.667,1.25$. ALCT $=3.9,5 * 2.602,3.9,0.667,1.25$. APTS $=8.0729 .4$. APT $=5.70085$. APBS $1=1.8654$, $A P B S 2=2.405$. $A P B S 3=8.3898$, $\mathrm{A} P \mathrm{~PB}$ W1 $=1.2436$ $A P B W 2=2.405$. $A$ PB W $3=8.3898$ 。 $A L I T=23.42$. EEND

E IN T GR

$N R E G=37$,

NSEG $=10$, $N S U B=10$, NCOOIS $=41$, $N$ COOI I $=661$. N CL BS $=29$, NCL BI $=460$. $N \operatorname{COL} T=247$.

$\begin{array}{lr}\text { DATA } & 1 \\ \text { DATA } & 2 \\ \text { DATA } & 3 \\ \text { DATA } & 4 \\ \text { DATA } & 5 \\ \text { DATA } & 6 \\ \text { DATA } & 7 \\ \text { DATA } & 8 \\ \text { DATA } & 9 \\ \text { DAIA } & 10 \\ \text { DATA } & 11 \\ \text { DATA } & 12 \\ \text { DATA } & 13 \\ \text { DATA } & 14 \\ \text { DATA } & 15 \\ \text { DETA } & 16 \\ \text { DATA } & 17 \\ \text { DATA } & 18 \\ \text { DATA } & 19 \\ \text { DATA } & 20 \\ \text { DATA } & 21 \\ \text { DATA } & 22 \\ \text { DETA } & 23 \\ \text { DATA } & 24 \\ \text { DATA } & 25 \\ \text { DETA } & 26 \\ \text { DETA } & 27 \\ \text { DATA } & 28 \\ \text { DATA } & 29 \\ \text { DATA } & 30 \\ & \end{array}$


Table A.3 (continued)

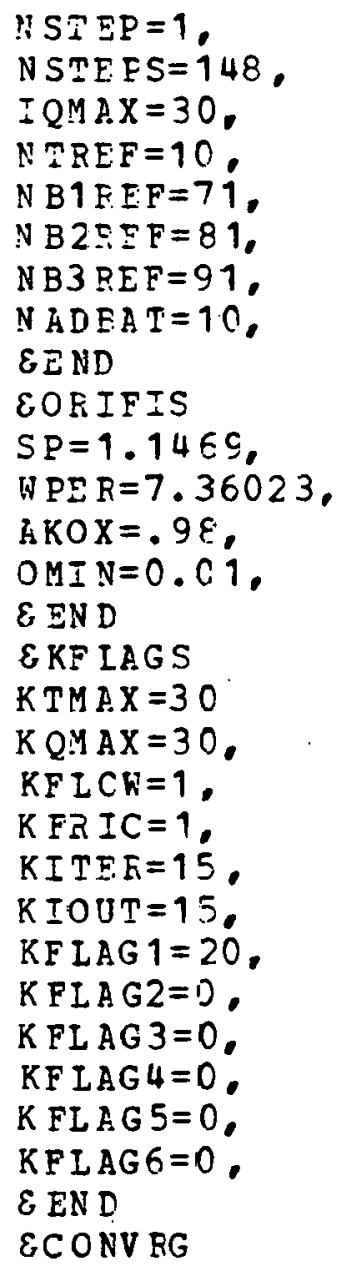


Table A. 3 (continued)

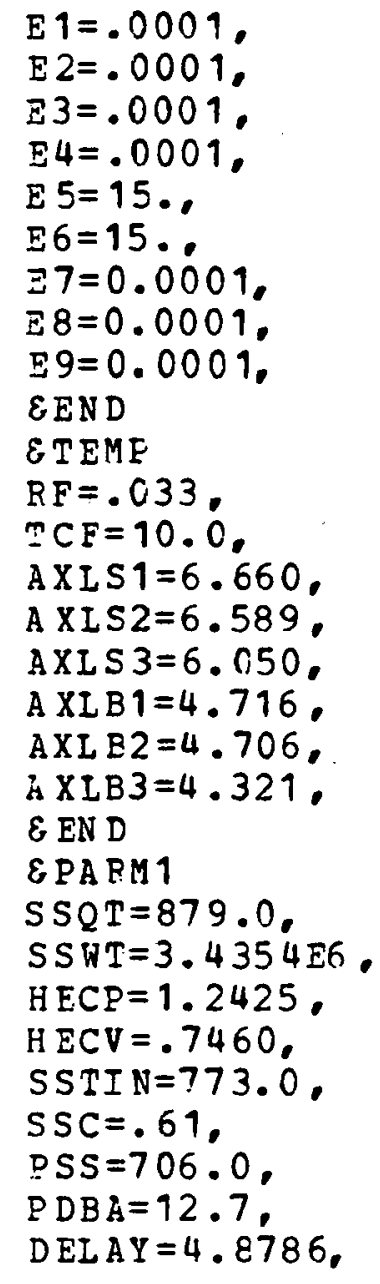




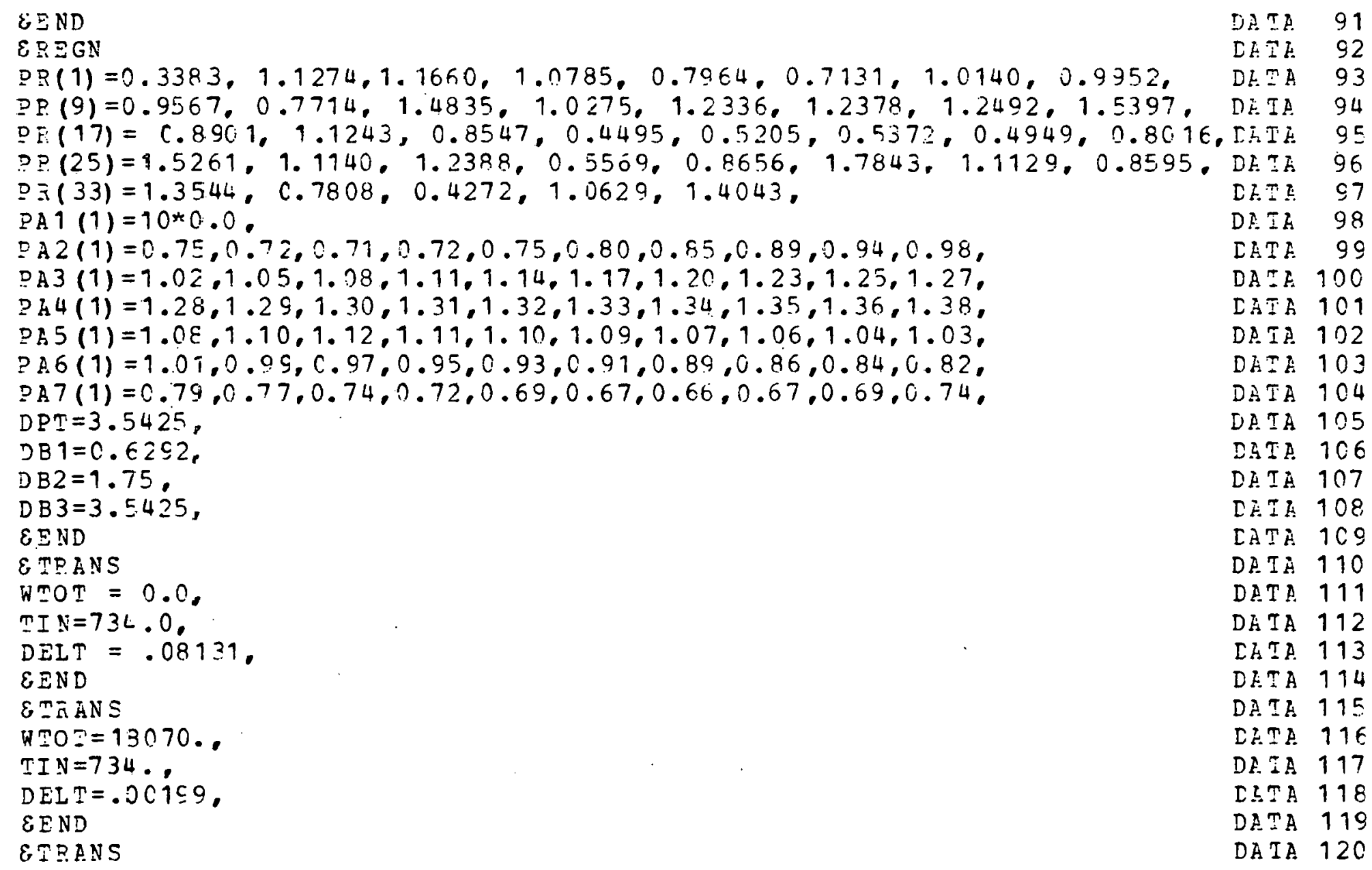


Tajle A.3 (continued)

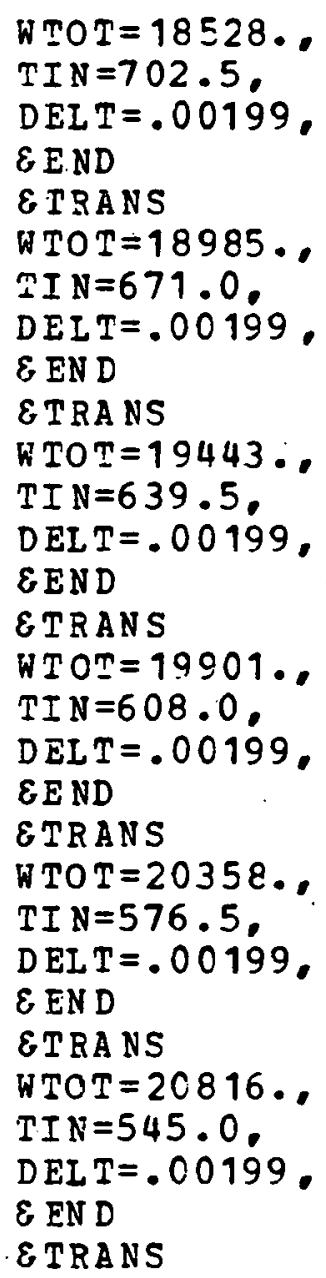

DB́TA 121

DATA 122

DATA 123

DATA 124

DAIA 125

IATA 126

DAIA 127

DATA 128

DATA 129

DATA 130

DATA 131

DA TA 132

LETA 133

DETA 134

DE TA 135

DATA 136

DAIA 137

DATA 138

DATA 139

DA. TA 140

EETA 141

DAIA 142

DATA 143

DATA 144

DATA 145

DA.TA 146

DATA 147

DA TA 148

IATA 149

DE TA 150 


\section{APPENDIX B}

This appendix contains selected computer output from the FLODIS code. The output represents the rapid depressurization accident described in the main body of this report. The first page is a listing of the input data for the code. The next page gives a summary of the flow and heat transfer input data along with nodal point information. At time zero (steady-state conditions) a reactor core map gives useful information about each refueling region. A detailed temperature distribution for the hottest refueling region is presented on the following page. Also at steady-state, a separate table is shown which summarizes the flow and pressure drop output. Transient information has been printed every hour thereafter; ending at $10 \mathrm{hr}$ into the accident. 


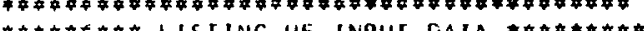

$4 \$ \# \# \#$ \#\# LISIING UF INPUI EAIA

ECUKE

RGWGTS $=297 \mathrm{C} .0000,1945.0060,1990.00 \mathrm{C}, 1995.0000,1445.0000,1992.0000,1945.0000$,

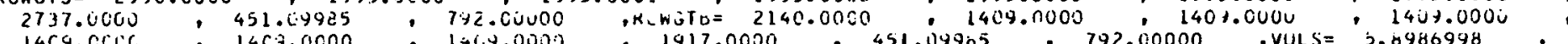

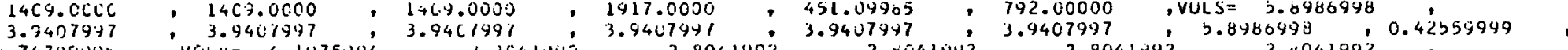

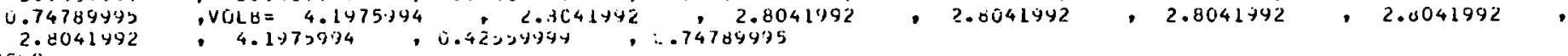

ECCOLiv

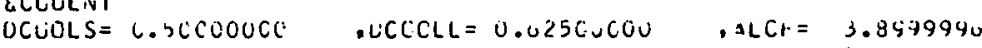

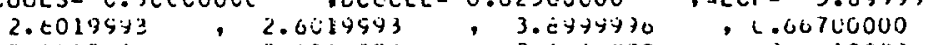

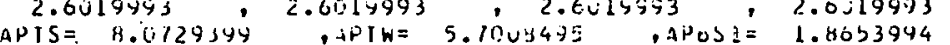

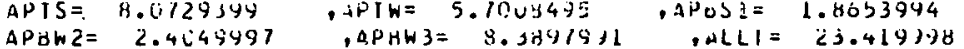

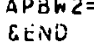

E INTSR

NRLG

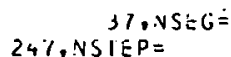

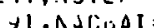

\&env

it IS

$S P=$

EKFLASS

KIMAX =

KFLAÜ2 $=$

KCNO

ECLINVi:s

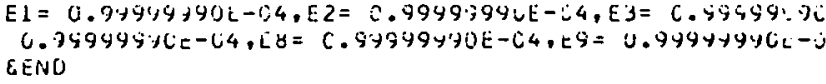

CT:MP

$R F=0.33000006 E-C L, T C F=16.000000$

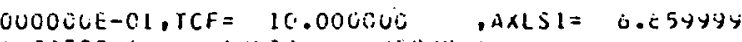

EEISC

EPARM

SSOT $=879 . C C C C O \quad$.SSWT $=3435400 \%$.

706.00000 , POBA $=12.70000$, ULLAY $=4.01=5942$

EENO

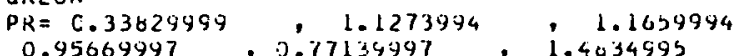

0.95669997

1.5260972

1.5260972
1.35439 .37

0.0

0.71499997

0.97499996

1.2299995

1.3299994

10999

0.9899994

j. 66999946

END

D. 0.77134907

- $1.1242 \times 90$

, 0.78079998

, v.

- $1.2301+91$

j.ju

- $0.70189494,0.71495191$

1., NCLILLS $=$

140 , $16 M A_{A}=$
, 0.42719996

ONIKEF=

10. NVUIRLF $=$

$11, N \cup 2 K E F=$

400,NCOLT $=$ 


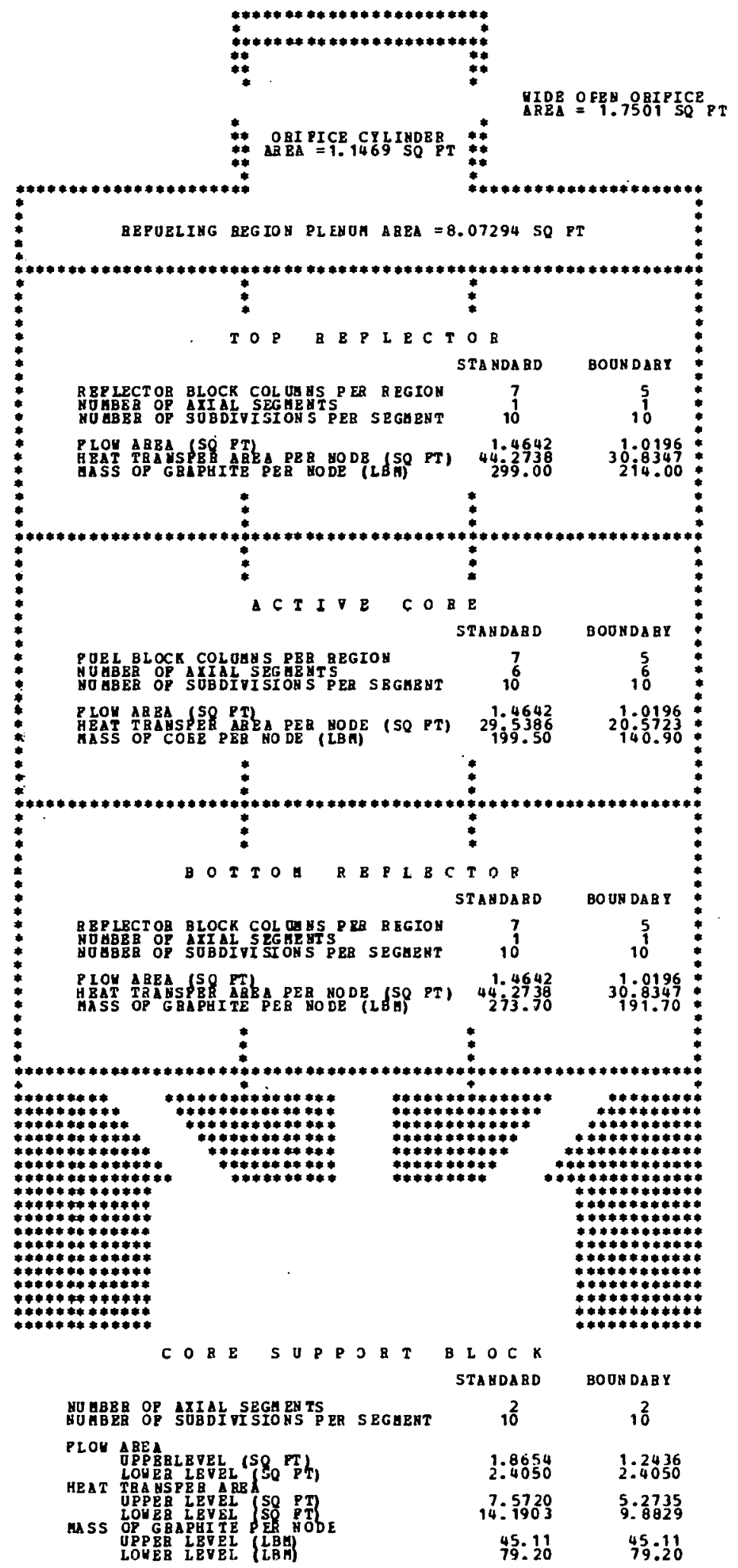




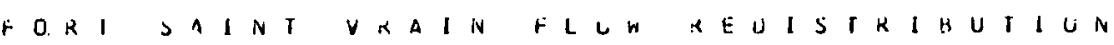

AFTER DE PRESSURIZATION ALCIDENT

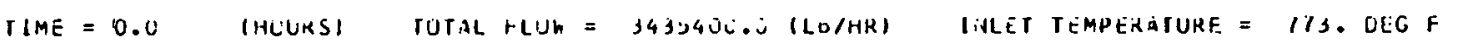

\begin{tabular}{|c|c|c|c|}
\hline $\begin{array}{l}\text { KEOLICN } 3 \% \\
\text { LOW }=\angle i 7 C=\end{array}$ & $\begin{aligned} & \text { K-GIUN } 30 \\
& \text { LUN }=103480.96\end{aligned}$ & $\begin{array}{c}\text { KLGISN } 37 \\
F L \ddot{H}=136 \% 121.68\end{array}$ & $\begin{array}{l}\text { Riviluid } 20 \\
F \text { LOW }=31259.34\end{array}$ \\
\hline $\begin{array}{l}\text { LUCAIIUN } 7,10 \\
\text { HUEL }=1,202 . \\
H E C L I=1409 .\end{array}$ & $\begin{array}{l}\text { LCCATIO: } 1,10 \\
\text { FLCL }=120 \% \\
H L \text { LUI }=140 \%\end{array}$ & $\begin{array}{l}\text { LULATILN } 7.16 \\
\text { rULL }=1013 . \\
\text { tiL LUR }=1469 .\end{array}$ & $\begin{array}{l}\text { LUCATILN } 7.10 \\
\text { tUEL }=150 \% \\
\text { HE UUT }=146 \%\end{array}$ \\
\hline
\end{tabular}

\begin{tabular}{|c|c|c|c|c|c|}
\hline & & & & & \\
\hline & & $H L U W=33 \% 13$. & $J W=7$ & & ( \\
\hline $\begin{aligned} L & =1335 .\end{aligned}$ & $\begin{array}{l}L U G+1 I L A \\
r U=L=\operatorname{lig} 1\end{array}$ & 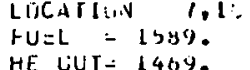 & $\begin{array}{l}\text { LUCATIUNA } \\
\text { tLEL = }\end{array}$ & 1596. & $\begin{array}{l}\text { HULL }=1511 \\
\mathrm{H}: \text { UU }=140 \mathrm{y}\end{array}$ \\
\hline
\end{tabular}

\begin{tabular}{|c|c|c|c|c|c|}
\hline $\begin{array}{l}\text { RE:CICV } 33 \\
\text { G }=131803.63\end{array}$ & KEUILIN 11 & 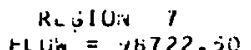 & RLUILN L & REVILN $y$ & KLUIlir 22 \\
\hline 03.03 & FLCW = 1000.490 & FLLi' $=.1722 .00$ & FLOW $=109763.0 \mathrm{O}$ & $F L O W=93143.81$ & $F L U H=32301.3$ \\
\hline $\begin{array}{l}\text { FUEL }=1011 . \\
H E L U I=140 \% .\end{array}$ & $\begin{array}{l}\text { FUEL }=1541 . \\
\text { HE LUT }=1464 .\end{array}$ & $\begin{array}{l}\text { PUE }=1590 . \\
H E \text { LUT }=146 \% .\end{array}$ & $\begin{array}{l}F U=L=1002 . \\
H \div L U T=1469 .\end{array}$ & $\begin{array}{l}\text { HUEL }=15 \% 0^{\circ} \\
\text { HE UUT }=140 \% .\end{array}$ & $\begin{array}{l}\text { FUEL }=1512{ }^{\circ} \\
H L U U I=1409 .\end{array}$ \\
\hline
\end{tabular}

REGIÜY 32
FLOW $=\$ 9771.77$
LUCATIONN 7,10
RULL $=1390$.

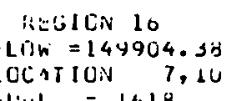

KEGICN O

रELIIN 1

REGIUN 3

KEGIUNO 10

r LUW $=00347.00 \quad F L U W=32+36.70$

FLCL $=1018$.

tut $=$ to 7 ,

LUCACLIIN 7.1

FLIUW $=113321.13$

LECATIUN 7 .

$H E L U T=146 \%$.

HC $\angle U T=1460^{\circ}$.

HL OUI $=1404$.

RUEL $=1003$.

FLUN = 20103.00

$F U=L=1533$.

RESICN 23

FLOW $=34416.57$

FUEATIUN 757

HiE UUT $=1409$

\begin{tabular}{|c|c|c|}
\hline KËGION & KEOION L & RLigluir \\
\hline$L L W=108351.3$ & FLUW $=1216<1.44$ & FLUn $=17537.06$ \\
\hline $\begin{array}{l}\text { LUCAIIC } 7,10 \\
\text { HUEL }=1601 . \\
\text { HE OUI }=146 \% .\end{array}$ & $\begin{array}{l}\text { LUCAIION } 7,10 \\
\text { FUEL }=160 \% \\
\text { AE DUT }=140 \% .\end{array}$ & $\begin{array}{l}\text { LLCATIO1, } 7,10 \\
\text { FUEL }=1580 . \\
\text { HE BUUI }=1469 .\end{array}$ \\
\hline
\end{tabular}

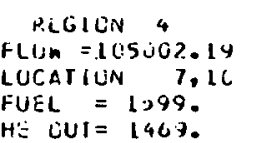

KLGIUNA 11

REDIOIY 24

LOCA $=144432.75 \quad F L U W=78043.31$

FUEL = 1010.10 LUCATIUN 7,10

$\begin{array}{lll}\text { HUEL }=1601 . & \text { FUEL }=160 \% & \text { FUEL }=1580 . \\ H E O T=146 \% & \text { TE DUI }=1469 . & \text { HE } B U I=1469 .\end{array}$

$H E$ OUI $=1407$.

$\begin{aligned} \text { HE LUT } & =1400^{\circ}\end{aligned}$

FULL $=1566$.
HE UUI $=1460^{\circ}$

\begin{tabular}{|c|c|c|c|c|}
\hline $\begin{array}{l}\text { KEUICN } 30 \\
\text { LUN }=173718\end{array}$ & $\begin{array}{l}\text { REGIGir } 14 \\
r L U H=1 \angle O>11.56\end{array}$ & $\begin{array}{l}\text { REGIIIN } 13 \\
F L U H=120102.63\end{array}$ & $\begin{array}{l}\text { RELION } 12 \\
\text { rLOW }=100036.81\end{array}$ & $\begin{array}{c}\text { REGIUN } 25 \\
\text { rLUW }=148560.2 \mathrm{~b}\end{array}$ \\
\hline 7,10 & LUCATIUN & $\angle C G+111 \mathrm{NON}$ & LUCAIIUN & LUCATIUNA \\
\hline $\begin{array}{l}U E L=1621 . \\
A E \text { CUT }=1469 .\end{array}$ & $\begin{array}{l}\text { FUEL }=1606 . \\
\text { RE EUT }=1469 .\end{array}$ & $\begin{array}{l}\text { FUEL }=1600 . \\
\text { HE HUT }=1460^{\circ}\end{array}$ & $\begin{array}{l}\text { FUEL }=1597 . \\
\text { HË UUT }=1464 .\end{array}$ & $\begin{array}{l}\text { FUEL }=1618 . \\
H E \text { UUT }=1469 .\end{array}$ \\
\hline
\end{tabular}

\begin{tabular}{|c|c|c|c|}
\hline $\begin{array}{l}\text { REGICN } \angle Y \\
\text { FLON }=60195.97\end{array}$ & $\begin{array}{c}R=1510 \text { N } 28 \\
F L O W=54219.50\end{array}$ & $\begin{array}{c}\text { REGIUN } 27 \\
\text { FLOH }=120 ; 008.61\end{array}$ & $\begin{array}{l}\text { REGIUN } 20 \\
\text { FLOW }=77470.25\end{array}$ \\
\hline $\begin{array}{l}\text { LCCAIICM } 1,10 \\
\text { FUEL }=1290 . \\
\text { HE ULT }=1404 .\end{array}$ & $\begin{array}{l}\text { LUCATIDIV } 7,10 \\
\text { FUEL }=1573 . \\
\text { HEC UUT }=1469 .\end{array}$ & $\begin{array}{l}\text { LUCATIUN } 7.10 \\
\text { HUEL }=1606^{\circ} \\
\text { HL UUT }=14699^{\circ}\end{array}$ & $\begin{array}{l}\text { LUCAIION } 7.10 \\
\text { HUEL }=160 \% . \\
\text { HE UUI }=146 \% .\end{array}$ \\
\hline
\end{tabular}




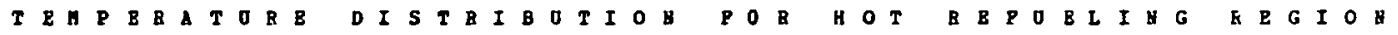

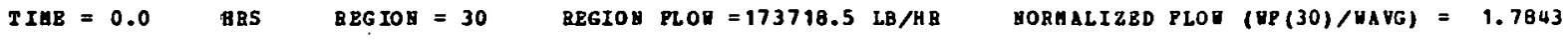

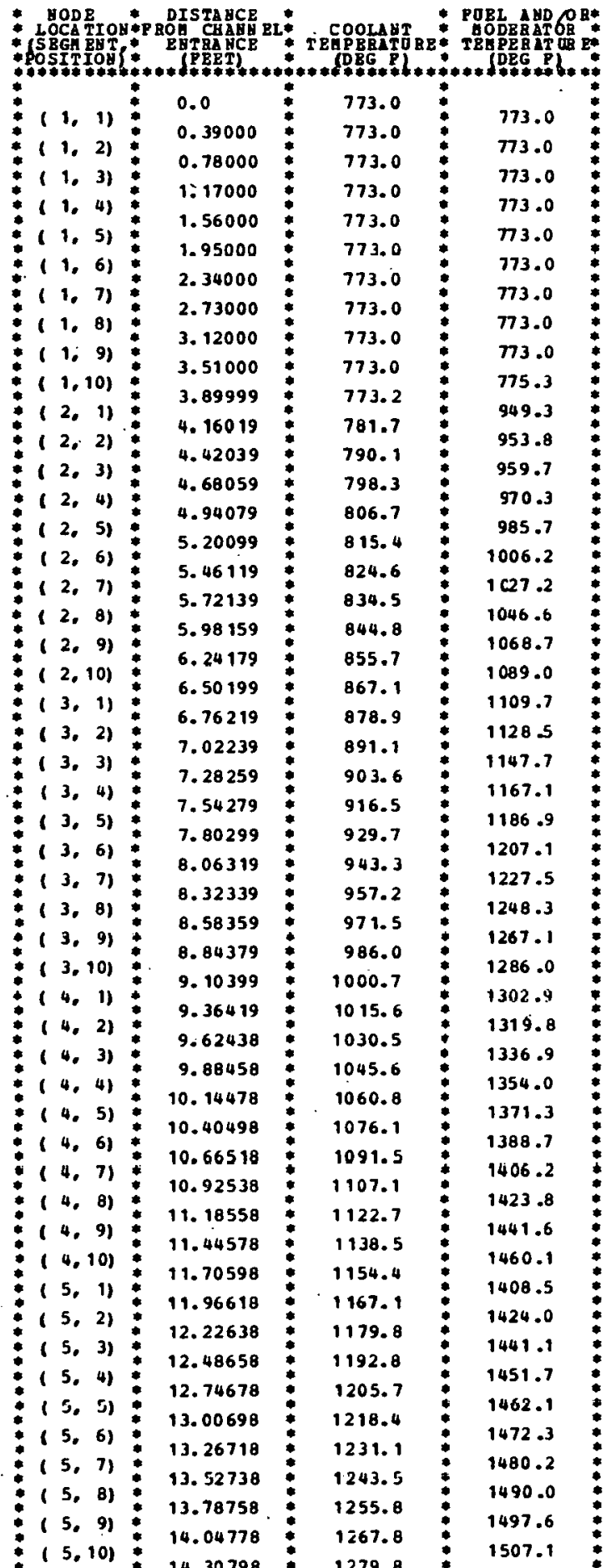

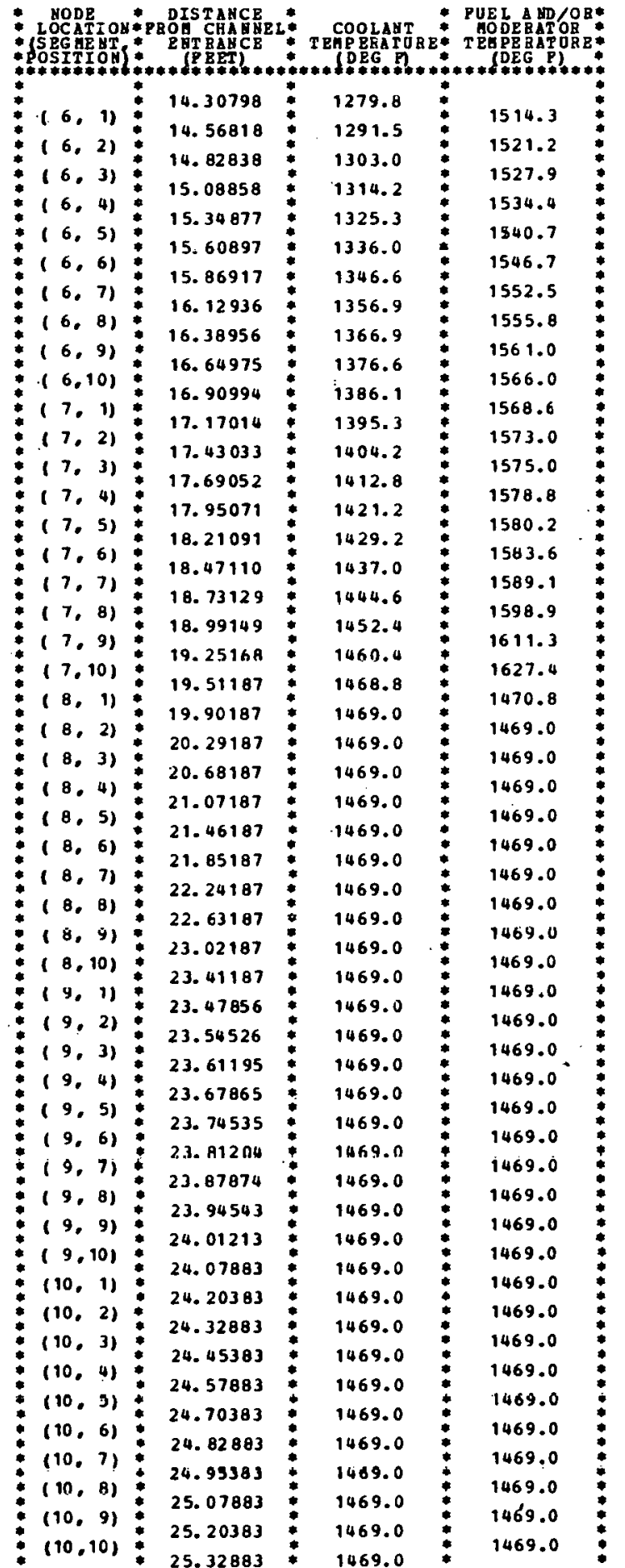




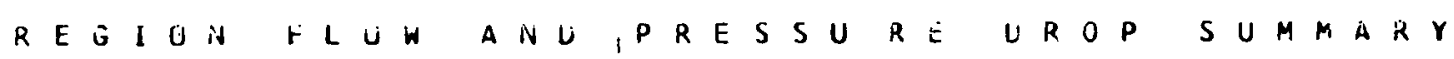

TIME $=0.0$ HUURS TUTAL FLOW $=3435400.0 \mathrm{LO} / \mathrm{LHK}$

REGILN HLOW IINFORMATION

\begin{tabular}{|c|c|c|c|c|}
\hline RËらICN & $\begin{array}{l}\text { RALIAL } \\
\text { PEAKIIJG } \\
\text { FACIOK }\end{array}$ & $\begin{array}{l}\text { REOLOIV } \\
\text { FLOH } \\
\text { (LB/HK) }\end{array}$ & $\begin{array}{c}\text { RAIIU TU } \\
\text { AV }=R A G E \\
\text { FLOW }\end{array}$ & $\begin{array}{l}6 \text { UT } \\
\text { IUTAL } \\
\text { FLOW }\end{array}$ \\
\hline 1 & 0.33830 & 32930.1 & 0.3303 & $i .0$ \\
\hline 2 & 1.12740 & 109703.0 & $1.12 / 4$ & 3.2 \\
\hline 3 & 1.10000 & 113321.1 & 1.1600 & 3.3 \\
\hline 4 & 1.01850 & 105002.2 & 1.0185 & 3.1 \\
\hline j & 0.19040 & 77537.1 & 0.7904 & 2.3 \\
\hline c & 0.11310 & 69427.0 & 0.7131 & $\angle .0$ \\
\hline 1 & $1.0140 \%$ & $\$ 81<2.5$ & 1.0140 & $\langle\rangle$. \\
\hline ه & し.ษษذ20 & $963 \div 2.1$ & 2 & $\therefore$. \\
\hline$\Rightarrow$ & 0.75670 & .13143 .8 & 0.4501 & 2.7 \\
\hline $1 j$ & 0.77140 & 75103.1 & 0.7714 & 2.2 \\
\hline 11 & 1.48350 & 144432.8 & 1.4830 & +.2 \\
\hline 12 & 1.02750 & 100036.8 & 1.2273 & $<. \exists$ \\
\hline 13 & 1.23300 & 120142.0 & 1.2336 & 3.5 \\
\hline 14 & 1.23780 & 120511.0 & $1.237 t i$ & ל. \\
\hline is & $1.24 ; 2 i j$ & $1216<1.4$ & $1.24 y 2$ & 3.5 \\
\hline 10 & 1.33970 & 149004.4 & $1.23+7$ & +.4 \\
\hline 17 & 0.89010 & 86639.7 & 0.3501 & $\angle \cdot b$ \\
\hline 13 & 1.124 .34 & 109401.2 & 1.1243 & 9.2 \\
\hline 1.3 & 0.85470 & 83213.1 & 0.8347 & 2.4 \\
\hline $2 \dot{u}$ & 0.44950 & 31259.3 & 0.4495 & U. \\
\hline 21 & 0.52050 & 50615.0 & $0.52 \cup 5$ & $1 . j$ \\
\hline 22 & 0.537261 & $523 \cup 1.5$ & & $i . j$ \\
\hline 23 & 0.49490 & 34410.6 & $0.474 y$ & 1.0 \\
\hline 24 & $0.8016 ;$ & 78043.3 & 0.8010 & $\therefore .3$ \\
\hline 25 & 1.52610 & 148580.3 & 1.5261 & 4.1 \\
\hline 20 & $1.114 \mathrm{Cij}$ & 77470.3 & 1.1146 & 2.3 \\
\hline 27 & 1.23480 & 120660.8 & 1.2380 & 3.3 \\
\hline 20 & 0.55690 & 54219.5 & J.556y & 1.6 \\
\hline 29 & $\overline{0} .86,60$ & 00190.0 & 0.3650 & 1.8 \\
\hline 30 & 1.78430 & 173710.5 & 1.7843 & 1. עי \\
\hline 31 & 1.11290 & 168351.3 & $1.11<y$ & 3.2 \\
\hline 32 & 0.85450 & 59771.8 & 0.3545 & $i .7$ \\
\hline $3 j$ & 1.35440 & 131803.6 & 1.3544 & 3.8 \\
\hline 34 & 0.78080 & 76013.3 & 0.7800 & $2 \cdot 2$ \\
\hline 35 & 0.42720 & $297 c b .3$ & $0.427 \%$ & ن.g \\
\hline 36 & 1.06290 & 103433.4 & 1.0627 & 3.0 \\
\hline 37 & 1.40430 & 136721.9 & $1.4 C_{43}$ & 4.0 \\
\hline
\end{tabular}

PLENUM TC PLENUM PRESSURE UROP $=9.80071$ PSIA

PRESSURE DROP INFOKMATIUN

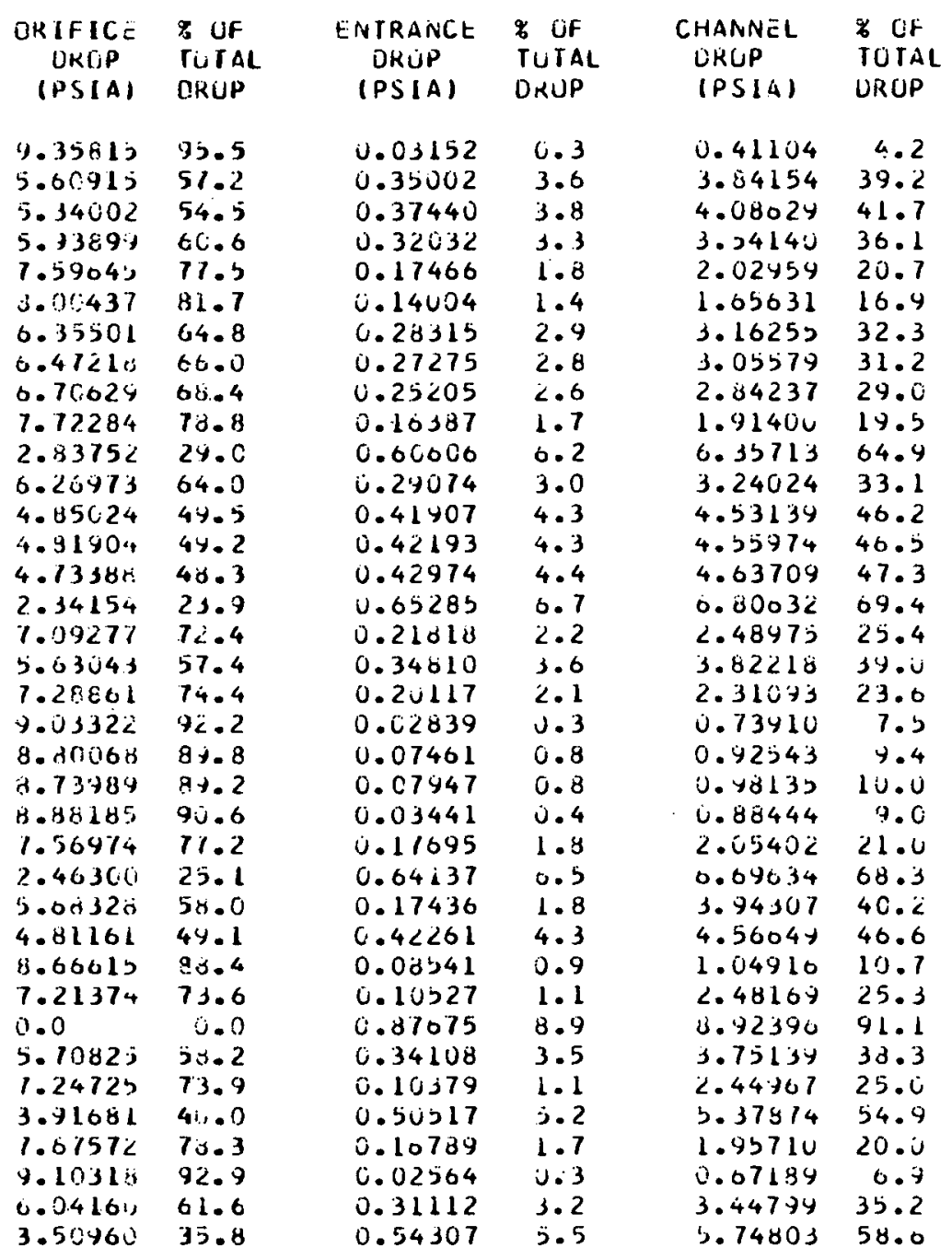




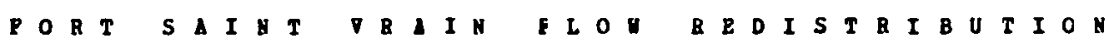

A P TER DEPREST UBIZATION ACCI DENT

TIEE $=1.00500$ (HOUBS)

rOTAL PLOY

33526.9 (L B B BB)

IHLET TEGPERATURE $=249$. DEG
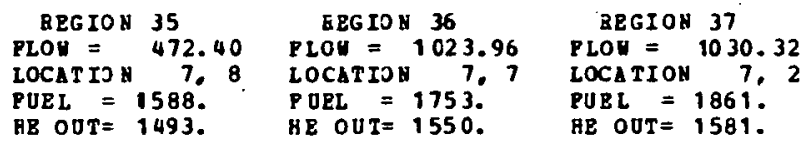

RBGIOY 20

PLON = 488.36

POCATIOA 7 ?"

PUEL $=1588$.
HB OOT $=1493$.

PORL $=1753$

PUBL $=1861$
AR OUT $=1581$.

HE OOT $=1495$.

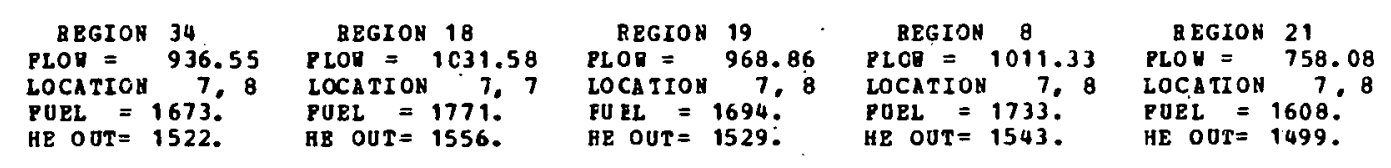
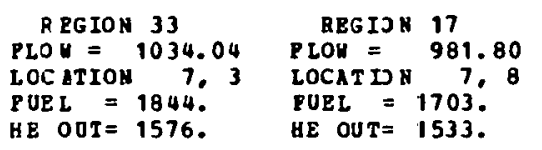

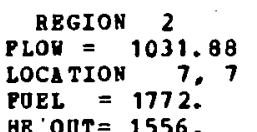

REGTON 9

LOCATIOX 7.8

HE OOT $=1539$.

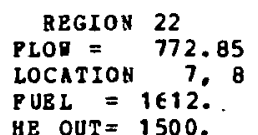

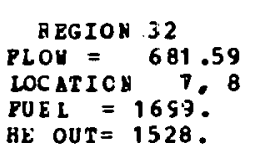

BEGIOX 16
PLOR= 1014.91
LOCATION 6.10
PORL = 1909.
HE OOT = 1591.

REGION 6
PION= 900.25
LOCATION 7.8
POEL $=1656$.
HB OOT $=1516$.

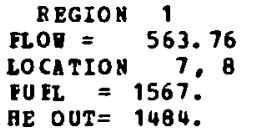

\section{BEGION} PLON $=1034.87$

IOCATION 7.7

PUE OUT $=1559$.
$H E$

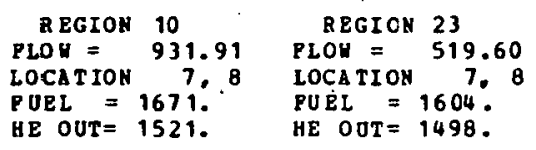

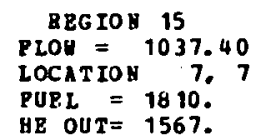

BEGIO 5

PLOU $=943.99$

LOCATION 7 .

PORL $=1678$.
HE OOT $=1524$.

BBGION

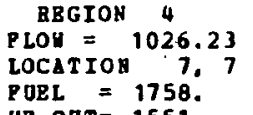

BEGION 19
PLOY $=1022.14$

. 7 .

POEL $=1758$

LOCATION 7 .

PURL $=1889$
HE OUT $=1587$

$\begin{array}{cl}\text { BEGION } 24 \\ \text { PLON }= & 946.40\end{array}$

LUCATIOY 7',

PUEL $=1679$.
HE OUT $=1524^{\circ}$.

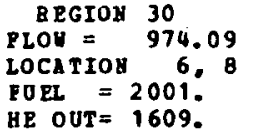

PLOH $=974.09$
LOCATIOA 6.8
FORL $=2001.8$
HE OUT $=1609$.
BEGIOY 14

PLOR $=1037.35$

LOCATI OB 7\%

HE OUT $=1566$.
REGIOU 13
PROA $=1037.30$
LOCATIOU 7.7
POEL $=1805$.
HE OOT $=1566$.

BEGIOH 12

PLOW $=1017.94$

LOCATIOA 7,

POEL $=1743$.
HE OUT $=1546$.
BEGION 25

PLOY $=1016.76$

LOCAT ION 7 .

$P$ UR $=1904^{\circ}$
HE OOT $=1590^{\circ}$
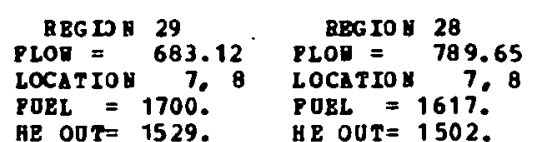

BBGIOH 27

BBGIOH 27
PLOW $=1037.35$
LOCATIOY 7,7
PUBL $=1807$.
HB OOT $=1566$.

BEGIOY 26

$07=719.82$

LCATIOY 7.

PUBL $=1774$
$\mathrm{HE}$ OUT $=1551$. 


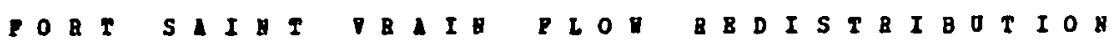

APTER DETEESSEBIZITIOA ACCIOEVI

TIAE $=2.00000$ (HODBS) TOTAL PLON $=34169.5$ (LB/AB) INLET TEHPBAATOBE $=235$. OEG P AIXED HEAN OUT = 1655. DRG P

\begin{tabular}{|c|c|c|c|}
\hline $\begin{array}{l}\text { BEG IOU } 35 \\
\text { PLOR }=475.54 \\
\text { LOCATIOH } 77,9 \\
\text { PORL }=1587 . \\
\text { HE OUT }=1519 .\end{array}$ & $\begin{array}{l}\text { EEGION } 36 \\
\text { PLOR }=1059.38 \\
\text { LOCATIOA } 7.9 \\
\text { POBL }=1797 . \\
\text { HE GOT }=1662 .\end{array}$ & $\begin{array}{l}\text { AEGION } 37 \\
\text { PLOU }=1027.80 \\
\text { LOCATIOR } 7.8 \\
\text { POEL }=1976 . \\
\text { HE OUT }=175 \% .\end{array}$ & $\begin{array}{l}\text { QRGION } 20 \\
\text { PLOW }=492.53 \\
\text { LOCATIOH } 7,9 \\
\text { PUEL }=1592 . \\
\text { HB OOT }=1522 .\end{array}$ \\
\hline
\end{tabular}

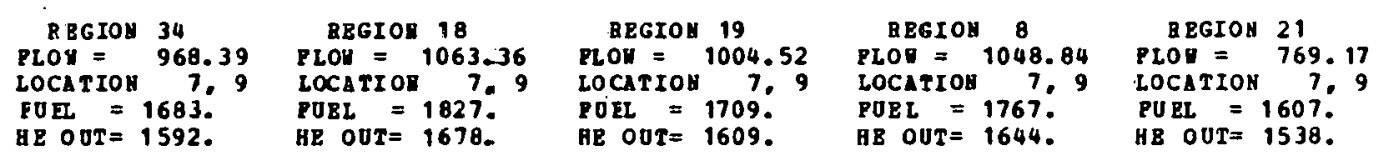

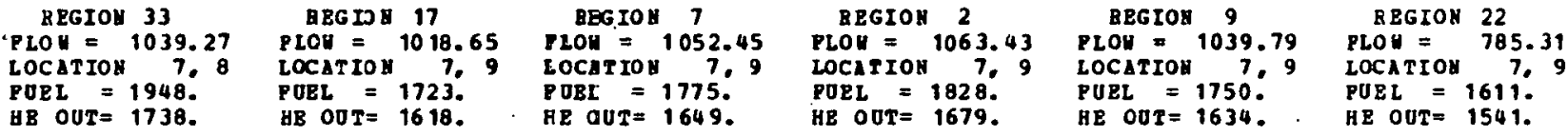

\begin{tabular}{|c|c|c|c|c|c|c|c|c|c|c|}
\hline $\begin{array}{l}\text { BEGION } 32 \\
\text { PLOR }=705.91 \\
\text { LOCATIOH } 7.9 \\
\text { PUEL }=1719.9 \\
\text { HE OUT }=1599 .\end{array}$ & $\begin{array}{l}\text { REGIOS } 16 \\
\text { PLOR }=989.60 \\
\text { LOCITION } 98.6 \\
\text { ROBL }=2055 . \\
\text { BE OOT }=1783 .\end{array}$ & $\begin{array}{l}\text { REGIOS } \\
\text { PLOH= } \\
\text { LOCATIOL } \\
\text { POBL = } \\
\text { GB OOT= }\end{array}$ & $\begin{array}{c}6 \\
927.36 \\
7.9 \\
1661.9 \\
1577 .\end{array}$ & 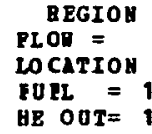 & $\begin{array}{c}1 \\
563.09 \\
7.9 \\
1565 . \\
1506\end{array}$ & $\begin{array}{l}\text { REGIOS } \\
\text { PLOQ = } \\
\text { LOCATIOA } \\
\text { POEL = } \\
\text { HE OUT= }\end{array}$ & $\begin{array}{c}3 \\
1063.26 \\
7.9 \\
1847.9 \\
1689\end{array}$ & $\begin{array}{l}\text { REGIOH } \\
\text { PLOR= } \\
\text { LOCATIOS } \\
\text { POBL = } \\
\text { HE OOT= }\end{array}$ & $\begin{array}{l}10 \\
963.15 \\
7 \% \\
1680 \\
1589 .\end{array}$ & $\begin{array}{l}\text { BEGIOH } 23 \\
\text { PLOA }=526.15 \\
\text { LOCATION } 7.9 \\
\text { POEL }=1604 . \\
\text { HE OUT }=1529 .\end{array}$ \\
\hline
\end{tabular}

\begin{tabular}{|c|c|c|c|c|c|c|}
\hline $\begin{array}{l}\text { BEGIOH } 31 \\
\text { TLOQ } 1063.01 \\
\text { LOCATIOA } 7,9 \\
\text { POEL = } 1821 . \\
\text { HE OOT }=1675 .\end{array}$ & $\begin{array}{l}\text { REGIOB } 15 \\
\text { FLOH }=1056.98 \\
\text { LOCATIOH } 7.8 \\
\text { POEL = } 1890 . \\
\text { HB OOT= } 1711 .\end{array}$ & 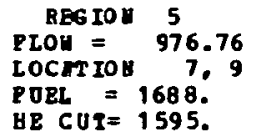 & $\begin{array}{l}\text { BEGIOH } \\
\text { PLOA = } 1 \\
\text { LOCATIOH } \\
\text { POBL }=18 \\
\text { BE OOT=18 }\end{array}$ & $\begin{array}{c}4 \\
1060.88 \\
7.9 \\
805.9 \\
1666 .\end{array}$ & $\begin{array}{l}\text { BEGIOH } 11 \\
\text { PLOH }=1006.50 \\
\text { LOCATIOH } 7,8 \\
\text { POBL }=2022 . \\
\text { HE OOT }=1770 .\end{array}$ & $\begin{array}{l}\text { RBGION } 24 \\
\text { PLOU }=979.47 \\
\text { LOCATION } 7.9 \\
\text { PUEL }=1690 . \\
\text { HE OUT }=1596 .\end{array}$ \\
\hline
\end{tabular}

\begin{tabular}{|c|c|c|c|c|c|c|}
\hline $\begin{array}{l}\text { BEGIOH } 30 \\
\text { PLOZ }=907.31 \\
\text { LOCATION } 97.5 \\
\text { POEL = } 2201.5 \\
\text { RE OOT= } 1835 .\end{array}$ & $\begin{array}{l}\text { BBGIOI } 14 \\
\text { PLOI }=1058.29 \\
\text { LOCATIOI } 7.8 \\
\text { PUBL }=1884 . \\
\text { HE OOT }=1768 .\end{array}$ & $\begin{array}{l}\text { BEGIOU } \\
\text { PLOQ } \\
\text { LOCATIOX } \\
\text { FOEL = } \\
\text { HE OOT= }\end{array}$ & $\begin{array}{r}13 \\
1058.73 \\
7.8 \\
1882: \\
1707\end{array}$ & $\begin{array}{l}\text { REGIOH } \\
\text { PLON = } \\
\text { LOCATIOU } \\
\text { POBL = } \\
\text { HE COT= }\end{array}$ & $\begin{array}{c}12 \\
1054.71 \\
7 \% 9 \\
1781: \\
1653 .\end{array}$ & $\begin{array}{l}\text { RBGIOU } 25 \\
\text { PLOE }=993.81 \\
\text { LOCA TION } 7.8 \\
\text { POEL }=2047 . \\
\text { HEOOT }=1780 .\end{array}$ \\
\hline
\end{tabular}

\begin{tabular}{|c|c|c|c|c|c|}
\hline $\begin{array}{l}\text { REGIOB } 29 \\
\text { FLOQ }=707.56 \\
\text { LOCATIO } 7 \% .9 \\
\text { POEL = 1721: } \\
\text { HE OOT= } 1601 .\end{array}$ & $\begin{array}{l}\text { BEGIOU } \\
\text { PEOT = } \\
\text { IOCATIOA } \\
\text { POBI }= \\
\text { BE OOT= }\end{array}$ & $\begin{array}{l}28 \\
803.75 \\
7.9 \\
1616 . \\
1545 .\end{array}$ & $\begin{array}{l}\text { ABGIOA } \\
\text { PLOQ = } \\
\text { LOCATIOH } \\
\text { PUEL = } \\
\text { GE OOF= }\end{array}$ & $\begin{array}{l}27 \\
1058.18 \\
7.8 \\
1885 . \\
1708 .\end{array}$ & $\begin{array}{l}\text { AEGIOH } 26 \\
\text { FLOU }=739.66 \\
\text { LOCATIOY } 7.9 \\
\text { POBL }=1833 . \\
\text { HE OUT }=1660 .\end{array}$ \\
\hline
\end{tabular}


PORI SAINTTEAIN ELON REDISTRIBUTION

A P T B DEPRESSUEIZAZION ACCIEEN

TIAE $=3.00000$ (HOUFS) TOTAL PLON $=34618.8$ (LE/HR) IKLET TEMPQRATUKE = 227. DEG P HIXED AEAN OUT = 170O. DE'́F

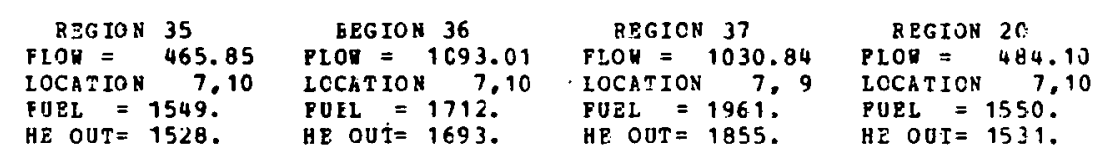

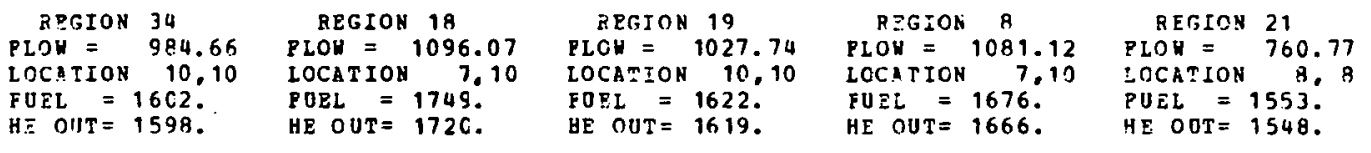

\begin{tabular}{|c|c|c|c|c|c|c|c|c|}
\hline $\begin{array}{l}\text { PEGION } 33 \\
\text { PLOU }=1050.16 \\
\text { ZOEGION } 7.9 \\
\text { PUEI }=1919 . \\
\text { HE CUT }=1830 .\end{array}$ & $\begin{array}{l}\text { REGION } 17 \\
\text { FICR }=1044.78 \\
\text { LCCATION } 10.10 \\
\text { FOEL }=1632 . \\
\text { HE OIIT }=1629 .\end{array}$ & $\begin{array}{l}\text { EBGION } 7 \\
\text { PLCK }=1085.33 \\
\text { ICCATION } 7.10 \\
\text { FUEL }=1685 . \\
\text { HE OOT }=1673 .\end{array}$ & $\begin{array}{l}\text { FEGIOI } \\
\text { PLON = } \\
\text { LOCATIOI } \\
\text { PUEL = } \\
\text { HD OUT }=\end{array}$ & $\begin{array}{c}2 \\
1096.04 \\
7.10 \\
1750 . \\
1721 .\end{array}$ & $\begin{array}{l}\text { REGIOI } \\
\text { FLON = } \\
\text { LOCATIO } \\
\text { PUEL = } \\
\text { HE OUT }\end{array}$ & $\begin{array}{l}99 \\
1070.32 \\
7.10 \\
1657 . \\
1652 .\end{array}$ & $\begin{array}{l}\text { AEGION } \\
\text { PLON = } \\
\text { LOCATION } \\
\text { FOEL }= \\
\text { HE OOT }=\end{array}$ & $\begin{array}{l}22 \\
778.18 \\
8.8 \\
1555 . \\
1551 .\end{array}$ \\
\hline
\end{tabular}

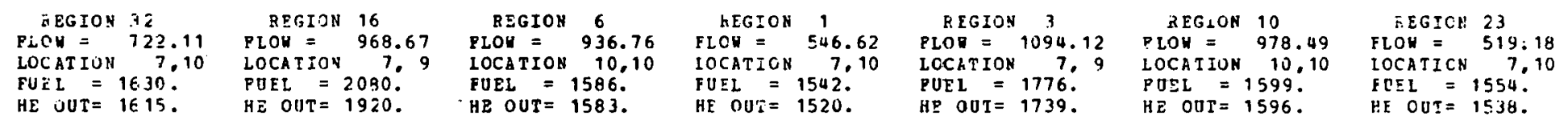

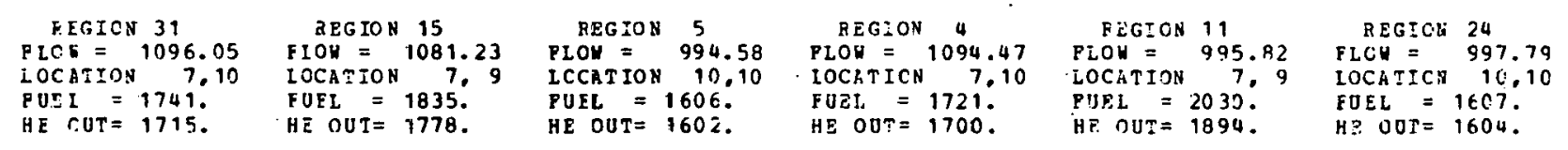

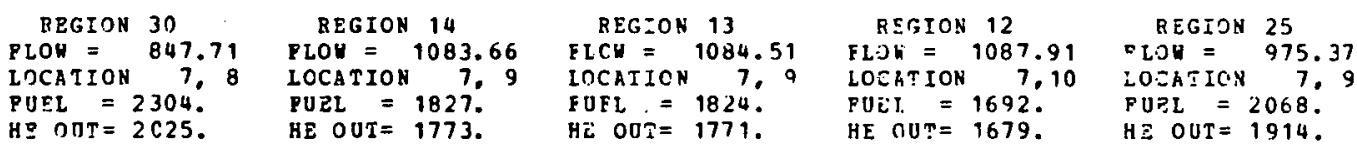

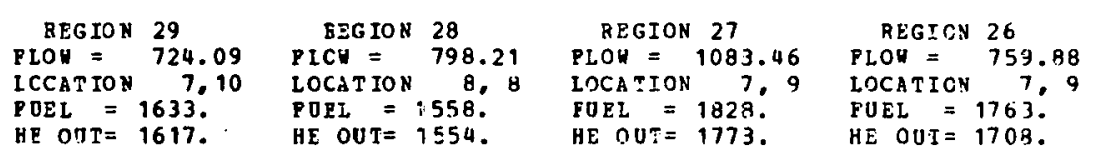


BORT SAINT VRAIN FLON EE DISTTEIEUTTION

A P I E R DE ZRESSUEIZATIONACCIEZN I

TI HE $=4.00000$ (HOU RS)

TCTAL PLCU $=34949.6$ (LB/HR)

INLET TEHPERATORI =

MIXED MEAN OUT $=1644$. DEG F

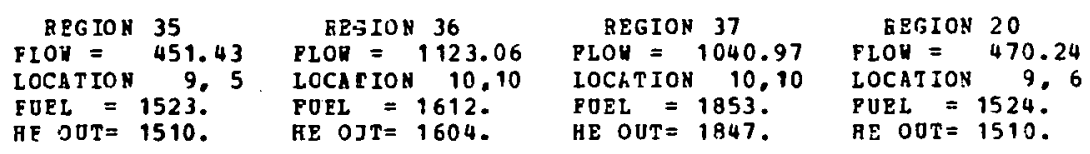

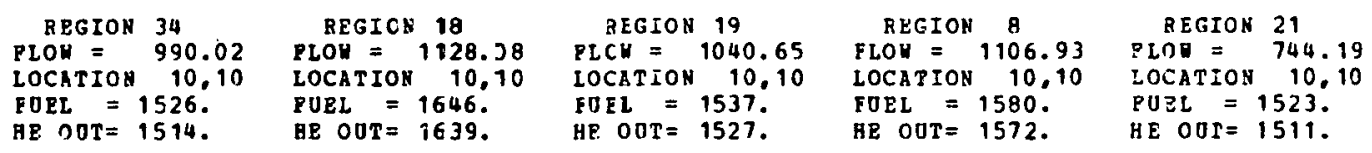

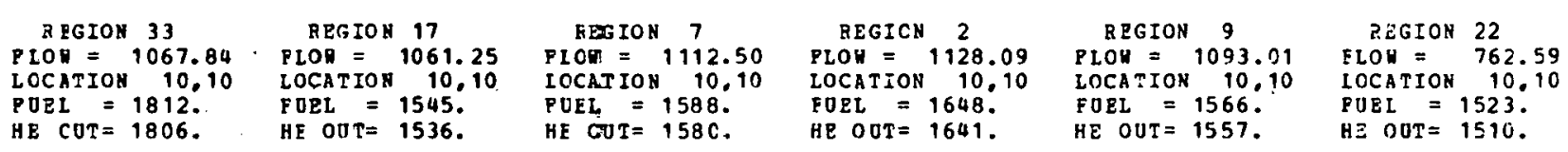

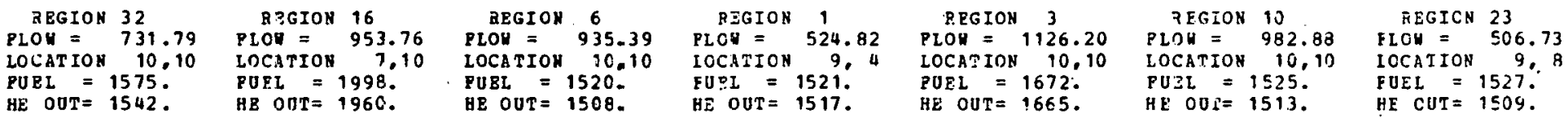

\begin{tabular}{|c|c|c|c|c|c|c|}
\hline $\begin{array}{l}\text { REGION } 31 \\
\text { PID = } 1127.85 \\
\text { LOCATIOY } \quad 10,10\end{array}$ & 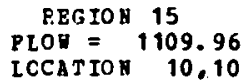 & $\begin{array}{l}\text { REGION } \\
\text { PICL }= \\
\text { LOCATION } 1001.52 \\
\text { TO, } 10,10\end{array}$ & $\begin{array}{l}\text { REGION } \\
\text { PLOR }= \\
\text { LOCATION } \\
1125.21 \\
10,10\end{array}$ & $\begin{array}{l}\text { REGION } \\
\text { PLON= } \\
\text { LOChIION }\end{array}$ & $\begin{array}{r}11 \\
991.82 \\
\quad 7.10\end{array}$ & $\begin{array}{l}\text { REGION } 24 \\
\text { FLON }=\quad 1005.26 \\
\text { LOCATION } 10.10\end{array}$ \\
\hline $\begin{array}{l}\text { POQ1 }=1639 . \\
\text { HE OOT }=1632 .\end{array}$ & $\begin{array}{l}\text { FUEL }=1731 . \\
\text { RE OUT }=1723 .\end{array}$ & $\begin{array}{l}\text { POFE }=1527 . \\
\text { HE COT }=1516 .\end{array}$ & $\begin{array}{l}\text { PUEL }=1620 . \\
\text { HE OUT }=1612 .\end{array}$ & $\begin{array}{l}\text { PUBL }= \\
\text { HE OOT }=\end{array}$ & $\begin{array}{l}1928 . \\
1914 .\end{array}$ & $\begin{array}{l}\text { FUR. }=1528 . \\
\text { HE OUI }=1597 .\end{array}$ \\
\hline
\end{tabular}

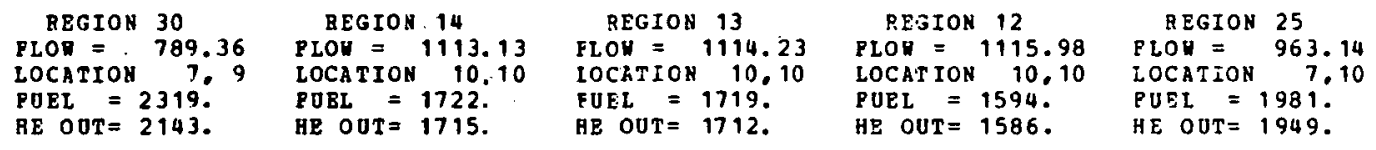

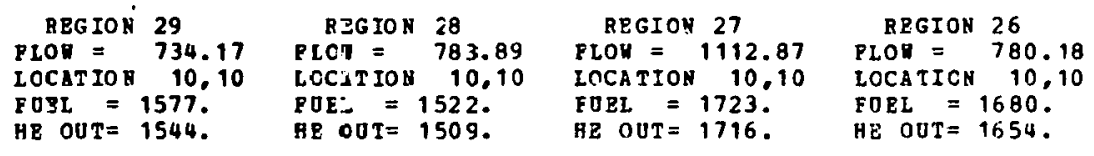


PORT SAINT VRAIN PLON REDISTEIBUTIOA

A P T E B DE P R E S S U R I Z A T I O N A C C I D E NT

TIHE $=5.00000$ (HOORS)
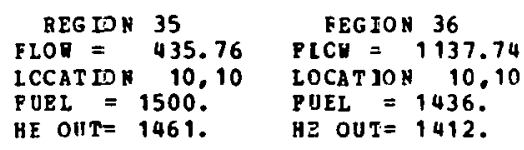

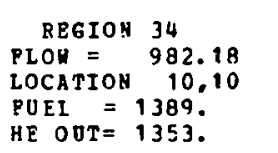

BEGION 18

REGION 19

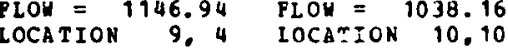
PUEL = 1467.

FOEL $=1388$.

HE OUT $=1354$.

\begin{abstract}
EEGION 8
PLOW $=1116.07$

LOCATION 10,10

$\begin{aligned} \text { FUEL } & =1414 . \\ \text { HE OUT } & =1385 .\end{aligned}$
PEGION 21
LOCA?ION 10,10

HE OUI $=1420$.
\end{abstract}

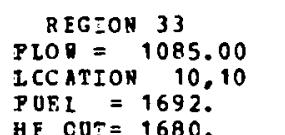

REGION 17
PLOW = 1061.55
ICCAEION 10,10
PUEL = 1391.
HE OUT $=1358$.

REGION 7
FICH = 1123.22
LCCATION 10.10
POEL $=1419$.
HEOUT 1391.

REGION 2
PLOR = 1147.13
IOCATION 9.4
PUEL = 1469.

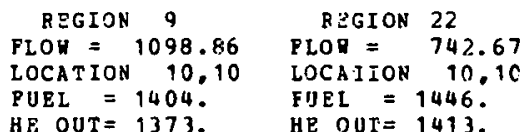

$\begin{array}{ll}\text { PUEL }=14044^{\circ} & \text { FIEL }=1446 . \\ H E \text { OUT }=1373 . & \text { HE OUT }=1413 .\end{array}$

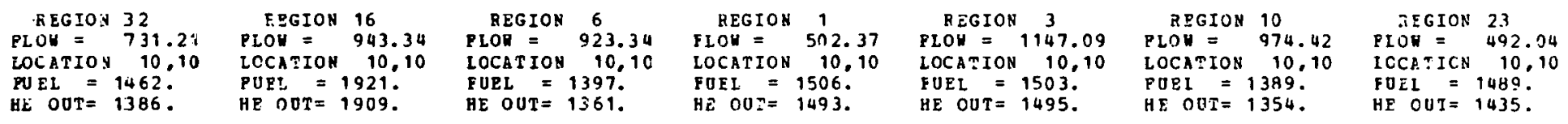
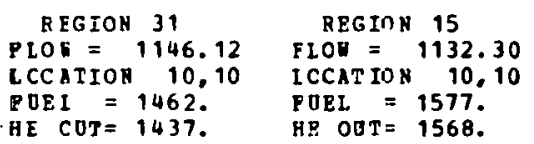

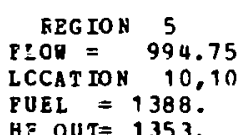

PEOR $=994.75$
LCCATION 10.1

HE OUI $=1353$.
PEGION - 4
ELOH $=1141.07$
LUEL $=1445^{\circ}$.
HE OUT $=1420$.

REGION 11
PLOH $=991.57$
LOCATION 10.10
POEL $=1850$.
HE OUT $=1838$.

REGION 24

FLOW = $\$ 98.86$

FOEL $=1387^{\circ}$.

HE OJT $=1353$.

\begin{tabular}{|c|c|c|c|c|}
\hline REGTO & REGTOY & FFGTON & BRGTOH & REGION 25 \\
\hline $\begin{array}{lr}\text { FLCN }= & 736.82 \\
\text { LOCATION } & 7.10\end{array}$ & PLOH $=1135.54$ & FLOW $=1136.64$ & FLOW $=1127.83$ & PLOU $=955.26$ \\
\hline $\begin{array}{l}\text { PUEL }=2277^{\circ} \\
\text { HE OUT }=2196 .\end{array}$ & $\begin{array}{l}\text { FURL }=1566 . \\
\text { BE OUT }=1557 .\end{array}$ & $\begin{array}{l}\text { FOEL }=1562 . \\
\text { HE OUT }=1553 .\end{array}$ & $\begin{array}{l}\text { FOEI }=1424 . \\
\text { HE OUT }=1.396 .\end{array}$ & $\begin{array}{l}\text { FUEL }=1904 . \\
\text { HE CUT }=1892 .\end{array}$ \\
\hline
\end{tabular}

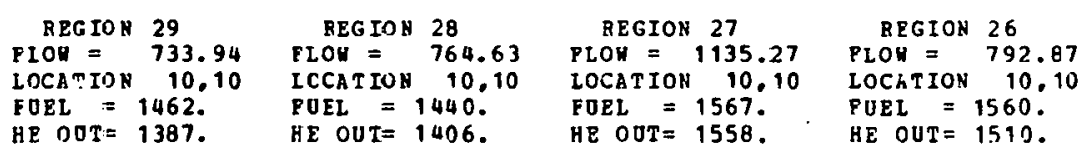


PORT SAINT VRAIN ELOH RBDISTRI BIIIIION

A P T B DEPRESSURIZATION ACCIDENT

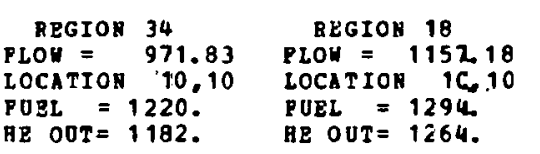

\begin{abstract}
REGION 19
FLOU $=\begin{array}{r}1030.46 \\ \text { LOCATION } 10,10\end{array}$

LOCATION 10,

HE OUT $=1175$.
\end{abstract}
REGION 8
PLON $=1116.20 \quad$ FLEGION 21
LOCATION 10,10 LOCATION 10,10
$\begin{array}{ll}\text { FUEL }=1231 . & \text { PUEL }=1351 . \\ \text { HE OUT }=1199 . & \text { HE OUT }=1305 .\end{array}$

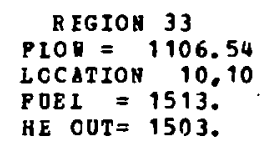
REGTOE 17
PLOM $=1055.47$
POCATIO 10.10
BOEL OOT $=1177$.
BE
REGIOH
PLOD $=1157.62$
PUPI $=1296$.
HE OUT $=1266$.

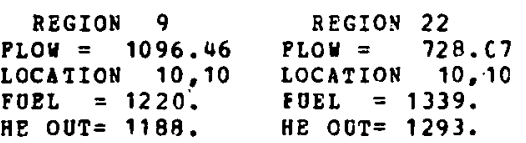

$\begin{array}{ll}\text { PLOH }=1096.46 & \text { PLOH }=728 . \mathrm{C} \\ \text { LOCAIION } 10,10 & \text { LOCATION } 10.10 \\ \text { FORL }=1220, & \text { EOEL }=1339 .\end{array}$

HE OUT $=1188 . \quad$ HE OOT $=1293$.

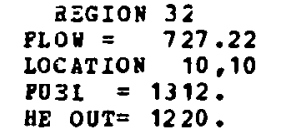

REGION 16

PLOH $=947.07$

LOCATIOA 10,10

PORL $=1815$.
HR OOT $=1798$.

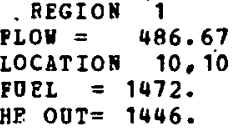

PLOW= 486.67
LOCATION 10,10
FOEL $=1472$.

HP OOT $=1446$.

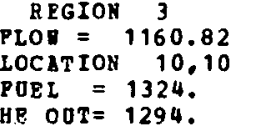

REGION 10 PLOW $=963.80$ LOCATION $10, .10$ PUBL $=1222$.
HE OOT $=1183$.
FEGICN 23 FLOW $=481.70$ IOCATICN 10,10 FOEL $=1424$.

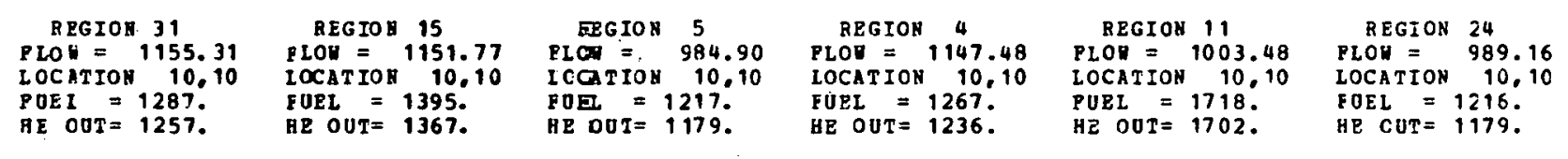

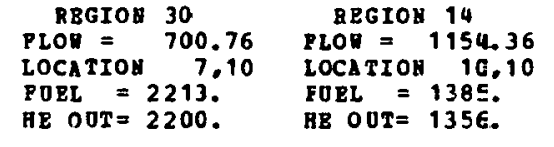

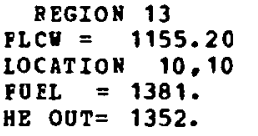
$=1155.20$
COEL $=1381$

REGION 1

FIOT $=1130.27$

IOCATION 10.10

POEL $=1242$.
$B E O O T=1212$.
REGION 25

FLOR $=961.13$

LOCATIOA 10,10

PUEL $=1791$.

HE OOT $=1774$.

\begin{tabular}{|c|c|c|c|c|c|c|}
\hline $\begin{array}{l}\text { REGIO } \\
\text { PLOR = } \\
\text { LGCATIO } \\
\text { POEL }= \\
\text { AE OOT= }\end{array}$ & $\begin{array}{l}29 \\
730.16 \\
10,10 \\
1312 . \\
1220 .\end{array}$ & $\begin{array}{l}\text { EEGION } \\
\text { PLCA = } \\
\text { LOQTION } \\
\text { POE = } \\
\text { BE OUT= }\end{array}$ & $\begin{array}{l}28 \\
750.24 \\
10.10 \\
1325 . \\
1279 .\end{array}$ & $\begin{array}{l}\text { REGIOI } \\
\text { PLOW= } \\
\text { LOCATIO } \\
\text { POEL = } \\
\text { HE OUT = }\end{array}$ & $\begin{array}{l}27 \\
1154.15 \\
10.10 \\
1385 . \\
1357 .\end{array}$ & $\begin{array}{l}\text { REGION } 26 \\
\text { PLOR }=801.39 \\
\text { LOCATION } 10.10 \\
\text { POEL }=1402 . \\
\text { HE OUT }=1319 .\end{array}$ \\
\hline
\end{tabular}


POET SAINT. TRAIN PLON GEDISTRIBUTION

A P T E B DEPRESS URIZATION ACCIEENT

TIHE $=7.00000$ (ROORS)

TOTAL PLOV $=34982.7$ (LB/HB)

INLET TERPEAATORE $=220$. DEG $P$ MIXED MEAN OUT $=1181$. DEG $F$

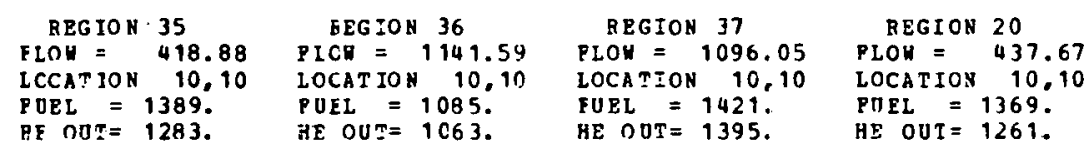

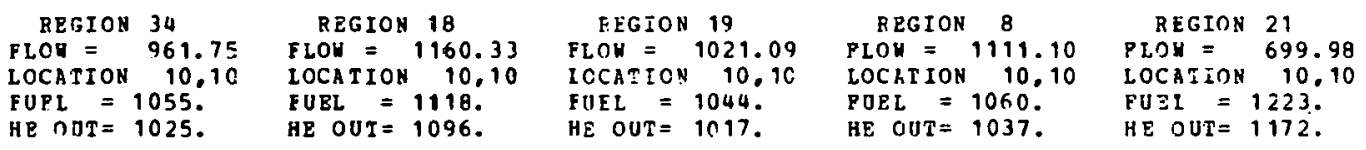

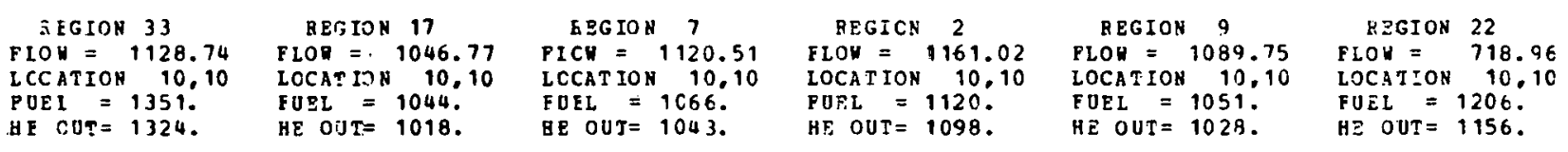

\begin{tabular}{|c|c|c|c|c|c|c|c|c|c|c|c|c|c|}
\hline $\begin{array}{c}\text { REG ION } \\
\text { FLOW = }\end{array}$ & $\begin{array}{l}32 \\
721.93\end{array}$ & $\begin{array}{r}\text { RPGION } \\
\text { PLOW }=\end{array}$ & $\begin{array}{l}16 \\
963.2 \mathrm{~g}\end{array}$ & $\begin{array}{c}\text { RZGION } \\
\text { PLOU }=\end{array}$ & 951.14 & $\begin{array}{l}\text { REGION } \\
\text { FLCH }=\end{array}$ & $\begin{array}{c}1 \\
477.69\end{array}$ & $\begin{array}{l}\text { XEGION } \\
\text { FIOH }\end{array}$ & ${ }^{N} 3_{167.47}^{3}$ & $\begin{array}{c}\text { REGION } \\
\text { FLOW = }\end{array}$ & $\begin{array}{ll}N & 10 \\
953.67\end{array}$ & $\begin{array}{c}E \leq G I C H \\
F L C H=\end{array}$ & $\begin{array}{l}23 \\
475.64\end{array}$ \\
\hline LOCATION & 10,10 & IOCATIOH & $\triangle \quad 10,10$ & LOCATION & 10,10 & LOCATIOH & 10,10 & LOCATION & $N \quad 10,10$ & LOCATION & $N \quad 10,10$ & LOCAIICN & 10,10 \\
\hline $\begin{array}{l}\text { POEL }= \\
\mathrm{HE} \text { OUT }=\end{array}$ & $\begin{array}{l}1146 . \\
1064 .\end{array}$ & $\begin{array}{l}\text { POEL = } \\
\mathrm{HEOOT}=\end{array}$ & $\begin{array}{l}1676 . \\
1659 .\end{array}$ & $\begin{array}{l}\text { FUEL = } \\
\text { HE OOT }\end{array}$ & $\begin{array}{l}1079 . \\
1044 .\end{array}$ & $\begin{array}{l}\text { FUEL }= \\
\text { HE OU? }=\end{array}$ & $\begin{array}{l}1423 . \\
1380 .\end{array}$ & $\begin{array}{l}\text { FUEL }= \\
H E \text { OUT }=\end{array}$ & $\begin{array}{l}1147 . \\
1124 .\end{array}$ & $\begin{array}{l}\text { FUEI = } \\
\text { HEOOT= }\end{array}$ & $\begin{array}{l}1058 . \\
1027 .\end{array}$ & $\begin{array}{l}\text { FUEL = } \\
\text { HE OUI }=\end{array}$ & $\begin{array}{l}1330 . \\
1219 .\end{array}$ \\
\hline
\end{tabular}

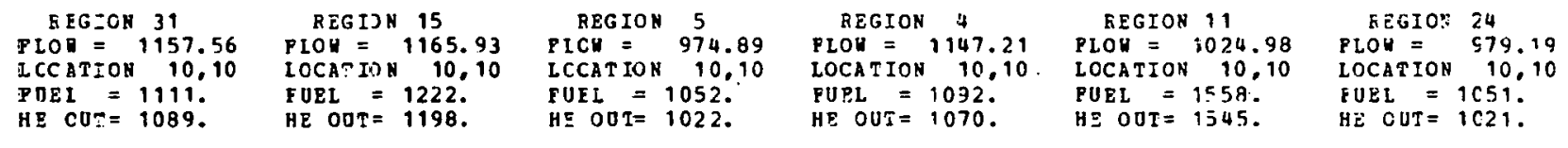

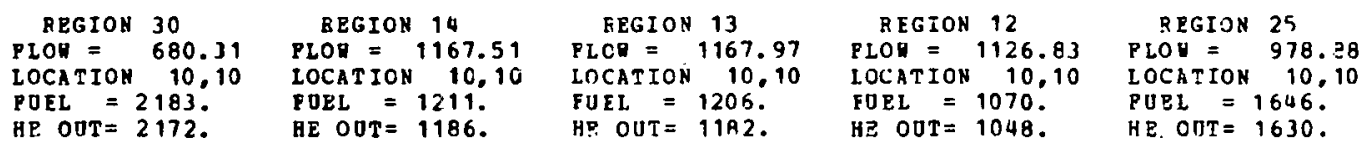

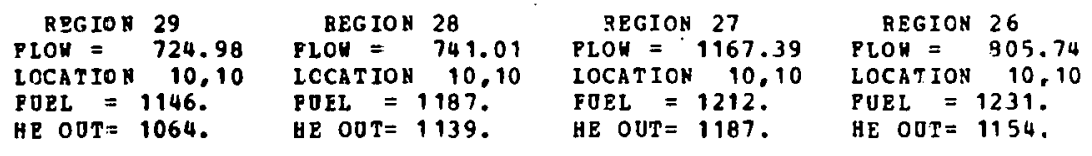


PORT SAINITEAIN PLON REDISTRIBUTION,

A P T E R DEPRESSTEIZATION ACCIEENT

TIAE $=8.00000$ (HOURS) TOTAL PEOH $=34982.7$ (LB/HR) IBLET TEMPRRATURE $=220$. DEG P MIXED MEAN OUT = 105A. DEG $F$

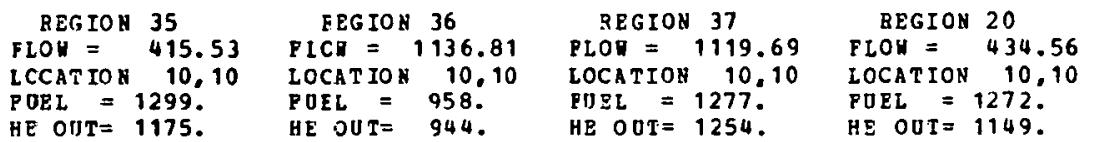

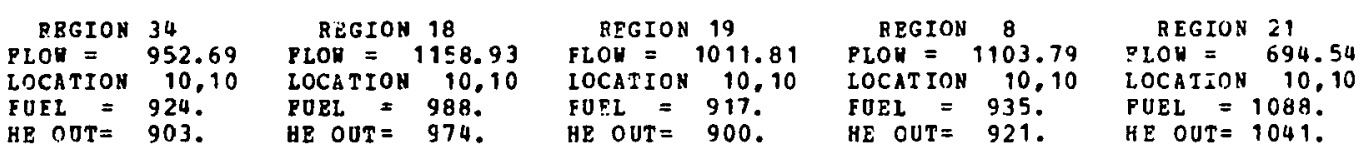

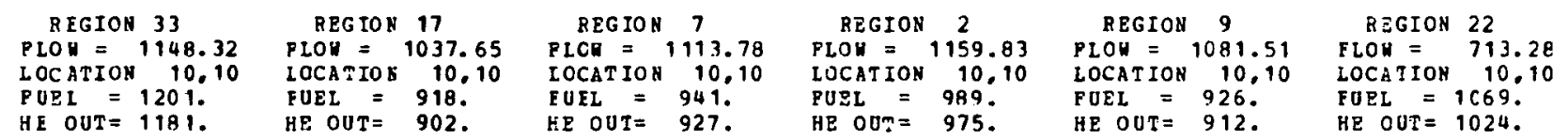

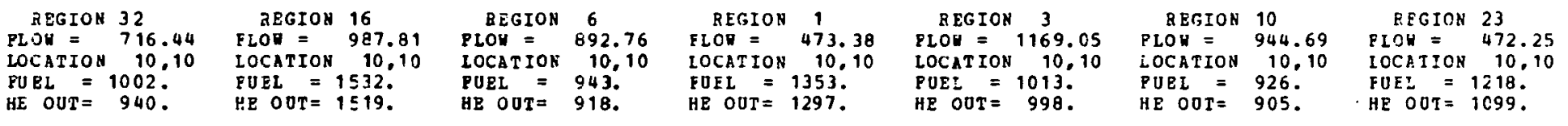

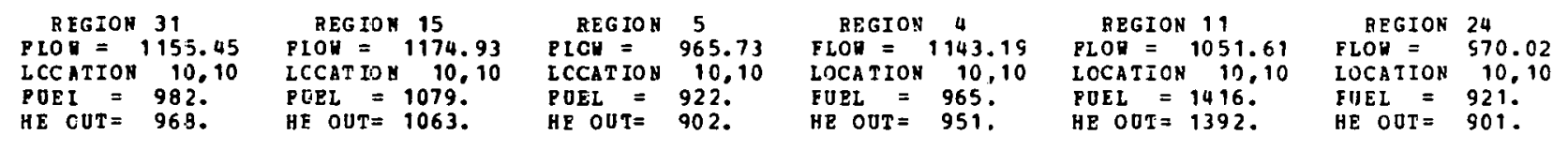

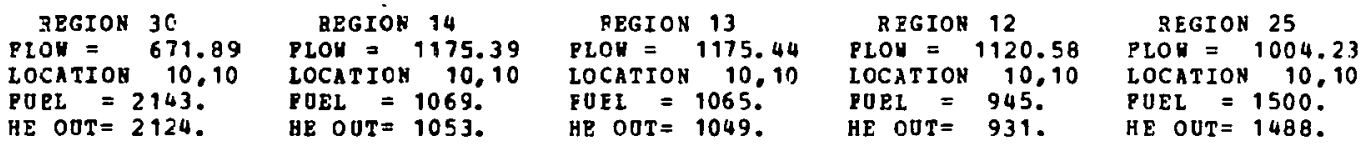

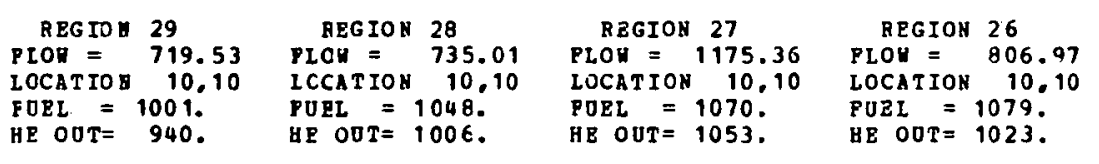


P J RT SAIIT VRAIN PLON REDISTRIBUTIION

A F TEE. DEPRESSURIZATION ACCILENT

TIME $=9.00(100 \quad$ (HOURS)

TOTAL PLOH

34982.7 (LB/HR)

IRLET TEMPERATURE $=220$. DEG P

MIXED MEAN OOT $=968$. DEG F

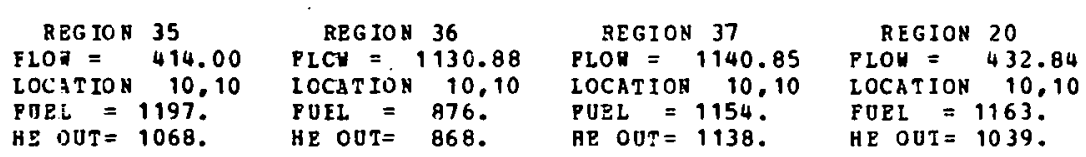

\begin{tabular}{|c|c|c|c|c|c|c|c|c|c|}
\hline REGION & 34 & REGION & 18 & REGION & 19 & REGIOI & 8 & REGION & \\
\hline PLON $=$ & 944.80 & PLOH = & 1155.44 & FLON $=$ & 1003.44 & PLON $=$ & 1096.24 & PLOU $=$ & 690.78 \\
\hline LOCATION & 10,10 & LOCATION & 10,10 & LOCATION & 10,10 & LOCATIOI & 10,10 & LOCATION & 10,10 \\
\hline PUPL = & $8 \geq 4$. & FUBL = & 901. & FOEL = & $833^{\circ}$ & FUEL $=$ & $\begin{array}{l}855 . \\
846 .\end{array}$ & FUEL = & 963. \\
\hline
\end{tabular}

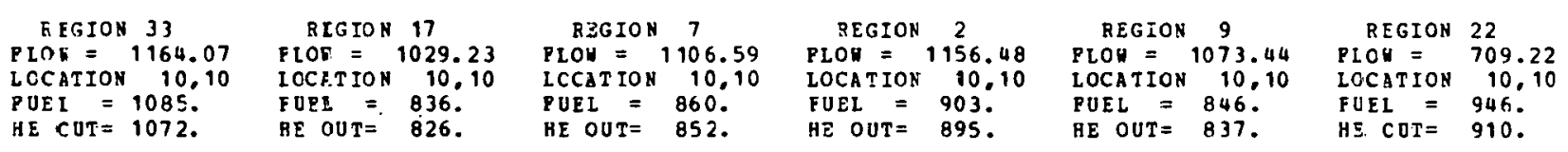

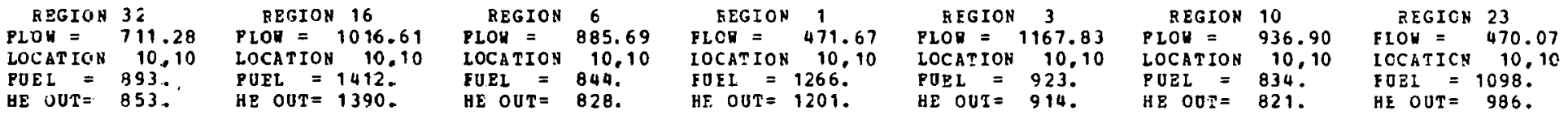

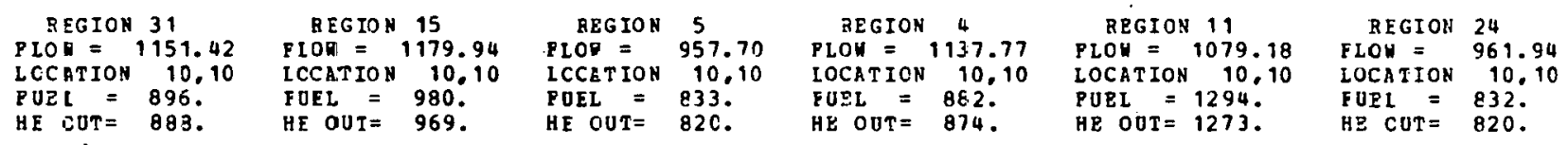

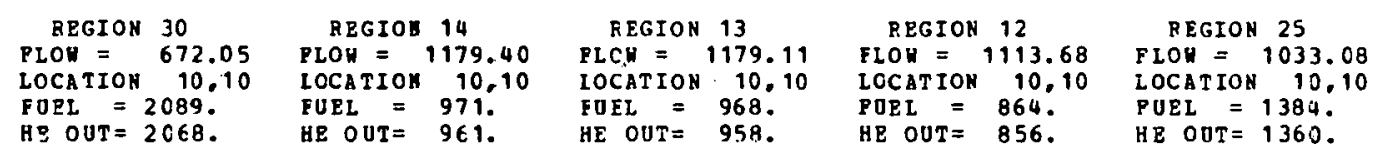

\begin{tabular}{|c|c|c|c|c|c|c|c|}
\hline $\begin{array}{l}\text { REJION } \\
\text { LOOR = } \\
\text { ICCATIOR } \\
\text { POEL = } \\
\text { HE OJT }=\end{array}$ & $\begin{array}{l}29 \\
714.38 \\
10,10 \\
894 . \\
853 .\end{array}$ & $\begin{array}{l}\text { BEGION } \\
\text { PICQ = } \\
\text { LOCATION } \\
\text { POEL = } \\
\text { HE OOT }=\end{array}$ & $\begin{array}{l}28 \\
730.60 \\
10,10 \\
927 . \\
895 .\end{array}$ & $\begin{array}{l}\text { REGION } \\
\text { PLOH = } \\
\text { LOCATIOA } \\
\text { FUEL = } \\
\text { HE OUT }=\end{array}$ & $\begin{array}{l}27 \\
1179.46 \\
10,10 \\
971 . \\
962 .\end{array}$ & $\begin{array}{l}\text { REGICN } \\
\text { PLOH = } \\
\text { LOCATION } \\
\text { PURL = } \\
\text { HE OOT }=\end{array}$ & $\begin{array}{l}26 \\
806.36 \\
10.10 \\
966 . \\
929 .\end{array}$ \\
\hline
\end{tabular}


POAT SAINT VAAIN FLOR REDISTRIBUTION

A TER DEIPESSUEIZZATION ACCITEN T

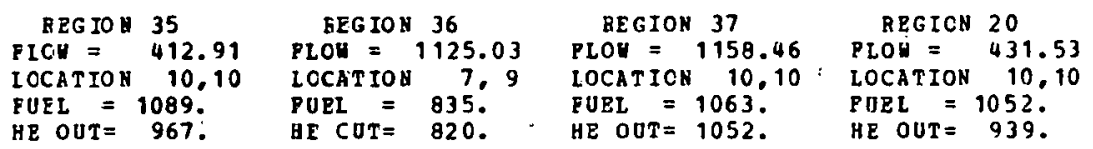

\begin{tabular}{|c|c|c|c|c|c|c|c|c|c|}
\hline $\begin{array}{l}\text { REGION } \\
\text { PLOA = } \\
\text { LOCATION } \\
\text { PUEL = } \\
\text { HE OOT }\end{array}$ & $\begin{array}{l}34 \\
938.00 \\
10.10 \\
779 . \\
765 .\end{array}$ & $\begin{array}{l}\text { REGIO } \\
\text { PLOD = } \\
\text { LOCATIO } \\
\text { PUEL = } \\
\text { HE OOT }\end{array}$ & $\begin{array}{r}18 \\
1151.30 \\
7.9 \\
858 . \\
843 .\end{array}$ & $\begin{array}{l}\text { REGION } \\
\text { FLCW = } \\
\text { IOCATIOON } \\
\text { FOEL = } \\
\text { HE OUT }=\end{array}$ & $\begin{array}{l}19 \\
996.18 \\
10,10 \\
781 . \\
771 .\end{array}$ & $\begin{array}{l}\text { REGION } \\
\text { FLOU = } \\
\text { LOCATION } \\
\text { PUEL = } \\
\text { HE OTT }\end{array}$ & $\begin{array}{c}A \\
1089.35 \\
7.9 \\
813 . \\
800 .\end{array}$ & $\begin{array}{l}\text { RPGION } \\
\text { PLOW = } \\
\text { LOCATION } \\
\text { PUEL = } \\
\text { HE OUT }=\end{array}$ & $\begin{array}{l}21 \\
687.57 \\
10,10 \\
861 . \\
834 .\end{array}$ \\
\hline
\end{tabular}

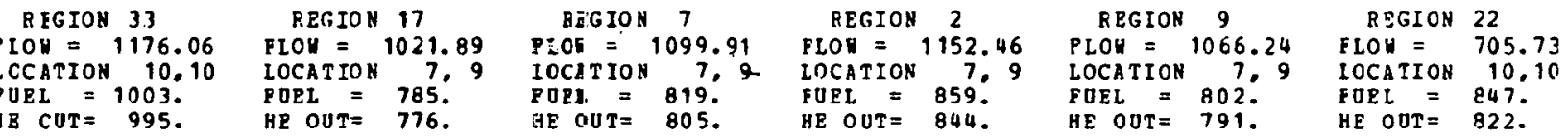

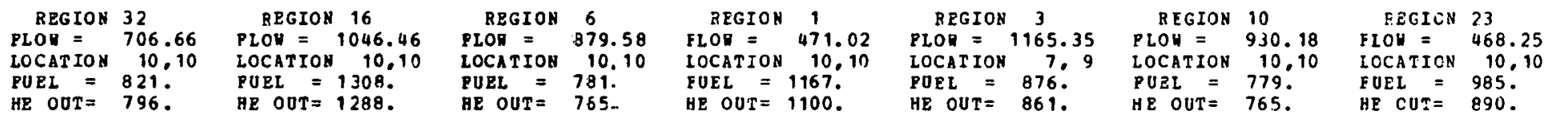

\begin{tabular}{|c|c|c|c|c|c|c|c|c|c|c|c|}
\hline $\begin{array}{l}\text { REGION } \\
\text { PLOW = } \\
\text { LCCATIOH } \\
\text { POEI = } \\
\text { HE OUT = }\end{array}$ & $\begin{array}{c}31 \\
1146.90 \\
7.9 \\
853 . \\
838 .\end{array}$ & $\begin{array}{l}\text { REGION } \\
\text { PLOW = } \\
\text { IOCATION } \\
\text { FOEL = } \\
\text { HB OUT }\end{array}$ & $\begin{array}{c}15 \\
1182.35 \\
7.9 \\
920 . \\
908 .\end{array}$ & $\begin{array}{l}\text { BZGION } \\
\text { PLOI = } \\
\text { LOCETION } \\
\text { FOE = } \\
\text { HE DOT= }\end{array}$ & $\begin{array}{l}5 \\
950.78 \\
10.10 \\
779: \\
766 .\end{array}$ & $\begin{array}{l}\text { REGION } \\
\text { PLOR = } \\
\text { LOCATION } \\
\text { PUEL = } \\
\text { HE OOT = }\end{array}$ & $\begin{array}{c}4 \\
1132.29 \\
7 \% \\
840.9 \\
825 .\end{array}$ & $\begin{array}{l}\text { REGION } \\
\text { PLOW = } \\
\text { LOCATION } \\
\text { PUEL = } \\
\text { HE OOT }=1\end{array}$ & $\begin{array}{c}11 \\
1105.36 \\
\times 10.10 \\
1190 . \\
1174 .\end{array}$ & $\begin{array}{l}\text { REGION } \\
\text { FOU = } \\
\text { LOCATION } \\
\text { FUEL = } \\
\text { HE OOT }=\end{array}$ & $\begin{array}{l}24 \\
954.98 \\
70.10 \\
779 . \\
766 .\end{array}$ \\
\hline
\end{tabular}

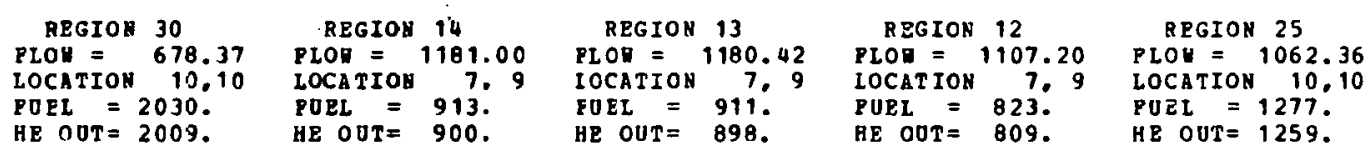

\begin{tabular}{|c|c|c|c|c|c|c|c|}
\hline $\begin{array}{l}\text { REGION } \\
\text { LOH = } \\
\text { CCATION } \\
\text { OEL = } \\
\text { E OUT }=\end{array}$ & $\begin{array}{l}29 \\
.709 .76 \\
10,10 \\
821 . \\
796 .\end{array}$ & $\begin{array}{l}\text { RZGION } \\
\text { PICA = } \\
\text { LCCATION } \\
\text { PUEL = } \\
\text { HE JOT }=\end{array}$ & $\begin{array}{l}28 \\
726.77 \\
10.10 \\
833 . \\
810 .\end{array}$ & $\begin{array}{l}\text { REGIOI } \\
\text { FLOR = } \\
\text { LOCATIOI } \\
\text { FUEL = } \\
\text { HE OOT }\end{array}$ & $\begin{array}{r}27 \\
1181.13 \\
7.9 \\
914 . \\
901 .\end{array}$ & $\begin{array}{l}\text { REGION } \\
\text { PLOR = } \\
\text { LOCATION } \\
\text { PUEL = } \\
\text { HE OUT= }\end{array}$ & $\begin{array}{l}26 \\
804.82 \\
10,10 \\
891: \\
869 .\end{array}$ \\
\hline
\end{tabular}


ORNL/TM-5365

Internal Distribution

1. J. L. Anderson

2. S. J. Ball

3. J. P. Callahan

4. K. W. Childs

5. J. C. Cleveland

6. T. E. Cole

7. J. H. Coobs

8. W. E. Cooper

9. D. A. Costanzo

10. W. B. Cottrell

11. F. L. Culler

12. J. R. Distefano

13. G. G. Fee

14. M. H. Fontana

15. Uri Gat

16. G. E. Giles, Jr.

17. M. J. Goglia

18. H. W. Hoffman

19. F. J. Homan

20. J. D. Jenkins

21-23. P. R. Kasten

24. A. L. Lotts
25. R. E. MacPherson/

J. A. Conlin

26. A. P. Malinauskas

27. W. J. McCarthy

28-37. D. D. Paul

38. H. Postma

39. M. W. Rosenthal

40-45. J. P. Sanders

46. Dunlap Scott

47. Myrtleen Sheldon

48. I. Spiewak

49. J. R. Tallackson

50. J. J. Taylor

51. D. B. Trauger

52. W. D. Turner

53. G. D. Whitman

54. W. J. Wilcox

55. ORNL Patent office

56-57. Central Research Library

58. Document Reference Section

59-63. Laboratory Records Department

64. Laboratory Records (RC)

\section{Extexnal Distribution}

65. Director, Division of Project Management, USNRC, Washington, D.C. 20555

66. Director, Division of Systems Safety, USNRC, Washington, D.C. 20555

67-72. Assistant Dfrector for Reactor Safety, Division of Systems Safety, USNRC, Washington, D.C. 20555

73. Assistant Director for Special Projects, Division of Project Management, USNRC, Washington, D.C. 20555

74-78. Chief, Special Reactors Branch, Division of Project Management, USNRC, Washington, D.C. 20555

79-80. Chief, Reactor Systems Branch, Division of Systems Safety, USNRC, Washington, D.C. 20555

81-82. Chief, Core Performance Branch, Division of Systems Safety, USNRC, Wash1ngton, D.C. 20555

83-84. Chief, Analysis Branch, Division of Systems Safety, USNRC, Washington, D.C. 20555

85. Director, office of Nuclear Regulatory Research, USNRC, Washington, D.C. 20555

86-87. Assistant Director, Research Coordination, Office of Nuclear Regulatory Rcsearch, USNRC, Washingtun, D.C. 20555 
88. Assistant Director, Advanced Reactor Safety Research, Division of Reactor Safety Research, USNRC, Washington, D.C. 20555

89. Chief, Experimental Gas-Cooled Reactor Safety Research Branch, Division of Reactor Safety Research, USNRC, Washington, D.C. 20555

90. Director, Division of Nuclear Research and Applications, ERDA, Washington, D.C. 20545

91. Assistant Director, Reactor Programs, NRA, ERDA, Washington, D.C. 20545

92. Chief, Gas Cooled Reactor Systems Branch, NRA/GS, ERDA, Washington, D.C. 20545

93. Chief, Fuels Technology Branch, NRA/GF, ERDA, Washington, D.C. 20545

94. Chief, Alternate Concepts Branch, NRA/GA, ERDA, Washington, D.C. 20545

95. Chief, Gas Reactor Safety Branch, NRA/RG, ERDA, Washington, D.C. 20545

96-98. Office of Reactor Safety Research Coordination, ERDA, Washington, D.C. 20545

99. Director, Research and Technical Support Division, ERDA, ORO

100. Director, Reactor Division, ERDA, ORO

101-127. Technical Information Center, ERDA, ORO

128. W. H. Beach, EGCRSRB, Division of Reactor Safety Research, USNRC, Washington, D.C. 20555

129-130. R. E. Ireland, Division of Systems Safety, USNRC, Washington, D.C. 20555

131. L. E. Phillips, Division of Systems Safety, USNRC, Washington, D.C. 20555

132. L. S. Rubenstein, Office of Nuclear Reactor Regulation, USNRC, Washington, D.C. 20555

133. L. H. Sullivan, Division of Systems Safety, USNRC, Washington, D.C. 20555

134-137. W. Kirk, Los Alamos Scientific Laboratory, P.0. Box 1663, Los Alamos, N. Mex. 87544

138-140. D. Schweitzer, Brookhaven National Laboratory, Upton, L.I., N.Y. 11973

141-146. General Atomic Company, Library, Room T-109, P.0. Box 81608, San Diego, Calif. 92138 